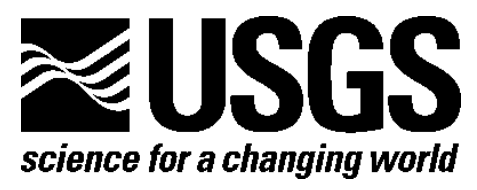

\title{
Review and Bibliometric Analysis of Published Literature Citing Data Produced by the Gap Analysis Program (GAP)
}

By Joan M. Ratz and Shannon J. Conk

Open-File Report 2013-1294

U.S. Department of the Interior

U.S. Geological Survey 


\section{U.S. Department of the Interior \\ SALLY JEWELL, Secretary}

\section{U.S. Geological Survey \\ Suzette M. Kimball, Acting Director}

U.S. Geological Survey, Reston, Virginia: 2014

For more information on the USGS-the Federal source for science about the Earth,

its natural and living resources, natural hazards, and the environment-visit

http://www.usgs.gov or call 1-888-ASK-USGS

For an overview of USGS information products, including maps, imagery, and publications, visit $h$ ttp://www.usgs.gov/pubprod

To order this and other USGS information products, visit $h$ ttp://store.usgs.gov

Suggested citation:

Ratz, J.M., and Conk, S.J., 2014, Review and bibliometric analysis of published literature citing data produced by the Gap Analysis Program (GAP): U.S. Geological Survey Open-File Report 2013-1294, 117 p., http://dx.doi.org/10.3133/ofr20131294.

ISSN 2331-1258 (online)

Any use of trade, firm, or product names is for descriptive purposes only and does not imply endorsement by the U.S. Government.

Although this information product, for the most part, is in the public domain, it also may contain copyrighted materials as noted in the text. Permission to reproduce copyrighted items must be secured from the copyright owner. 


\section{Contents}

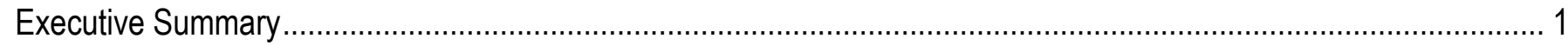

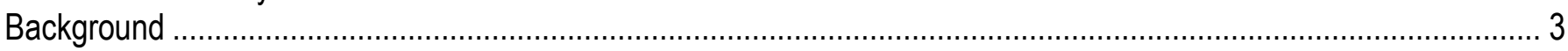

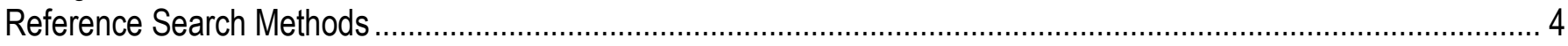

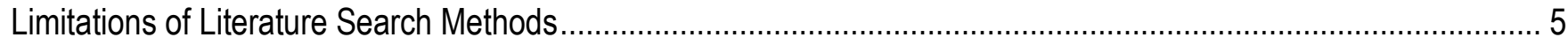

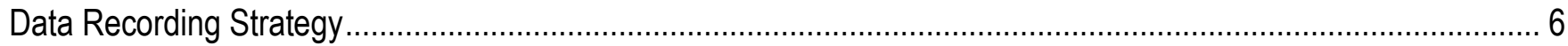

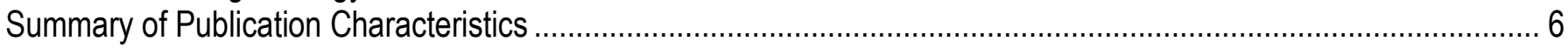

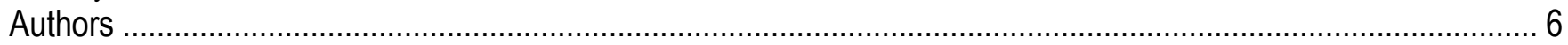

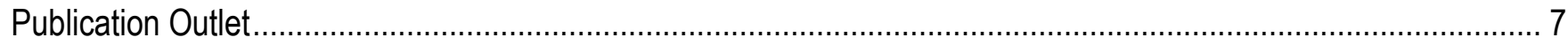

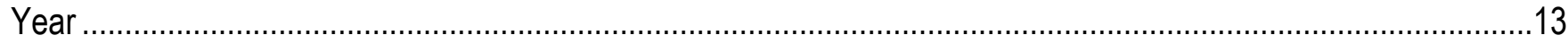

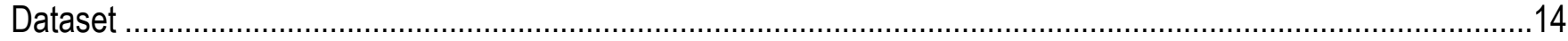

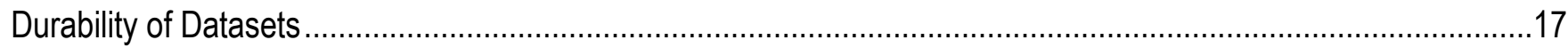

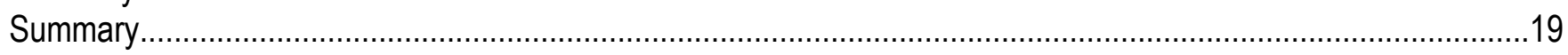

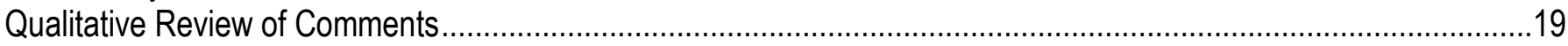

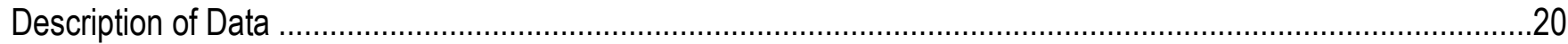

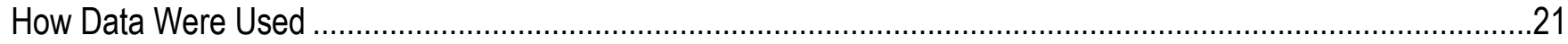

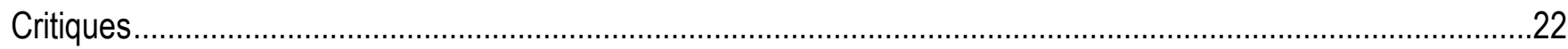

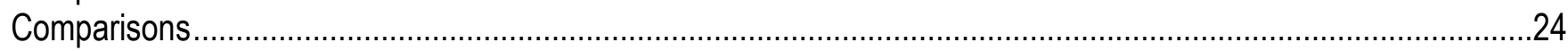

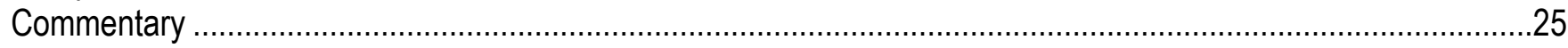

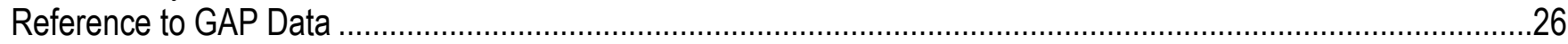

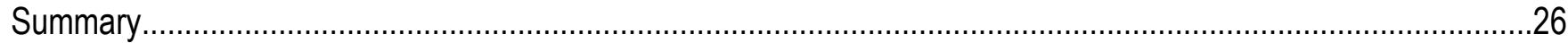

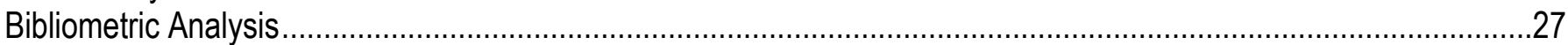

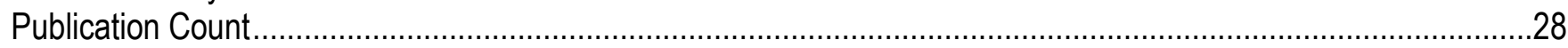

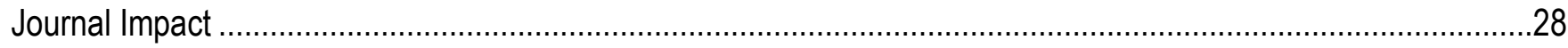

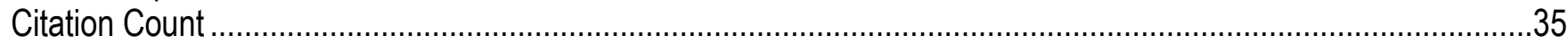

Summary

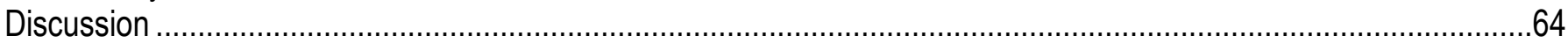

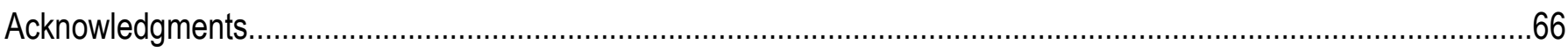

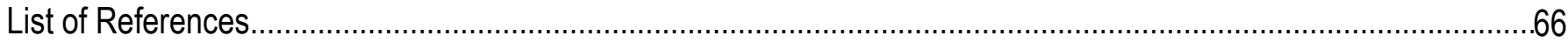

\section{Figures}

Figure 1. Proportion of authors receiving credit categorized by number of publications ……............................... 7

Figure 2. Percent of publications by outlet type ……………................................................................ 8

Figure 3. Number of publications citing state, regional, and national GAP data by year ..................................... 13

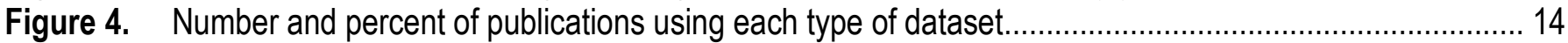

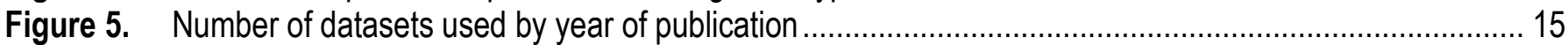

Figure 6. Frequency of use for each type of dataset, grouped by state, region, and national level........................ 16

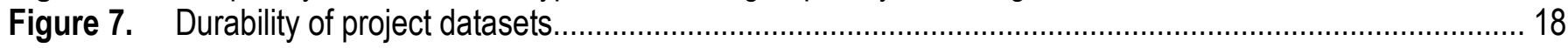

Figure 8. Number and percent of articles published in journals at each quartile rank ....................................... 35

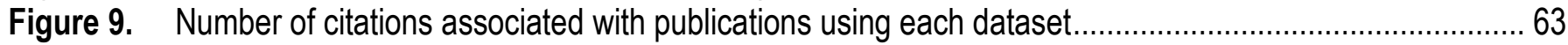

\section{Tables}

Table 1. Journal title and number of articles from each journal................................................................. 9

Table 2. Number of articles appearing in each journal, impact factor, discipline, and journal impact rank ........... 28

Table 3. Citation count for publications using GAP data ......................................................................... 37

Table 4. Datasets, number of publications using each dataset, and number of citations................................... 57 


\title{
Review and Bibliometric Analysis of Published Literature Citing Data Produced by the Gap Analysis Program (GAP)
}

\author{
By Joan M. Ratz and Shannon J. Conk
}

\section{Executive Summary}

The Gap Analysis Program (GAP) of the U.S. Geological Survey (USGS) produces geospatial datasets providing information on land cover, predicted species distributions, stewardship (ownership and conservation status), and an analysis dataset which synthesizes the other three datasets. The intent in providing these datasets is to support the conservation of biodiversity. The datasets are made available at no cost. The initial datasets were created at the state level. More recent datasets have been assembled at regional and national levels.

GAP entered an agreement with the Policy Analysis and Science Assistance branch of the USGS to conduct an evaluation to describe the effect that using GAP data has on those who utilize the datasets (GAP users). The evaluation project included multiple components: a discussion regarding use of GAP data conducted with participants at a GAP conference, a literature review of publications that cited use of GAP data, and a survey of GAP users. The findings of the published literature search were used to identify topics to include on the survey.

This report summarizes the literature search, the characteristics of the resulting set of publications, the emergent themes from statements made regarding GAP data, and a bibliometric analysis of the publications. We cannot claim that this list includes all publications that have used GAP data. Given the time lapse that is common in the publishing process, more recent datasets may be cited less frequently in this list of publications. Reports or products that used GAP data may be produced but never published in print or released online. In that case, our search strategies would not have located those reports. Authors may have used GAP data but failed to cite it in such a way that the search strategies we used would have located those publications. These are common issues when using a literature search as part of an evaluation project. Although the final list of publications we identified is not comprehensive, this set of publications can be considered a sufficient sample of those citing GAP data and suitable for the descriptive analyses we conducted.

We searched Web of Science ${ }^{\complement}$, Scopus ${ }^{\circledR}$, Google Scholar, CSA Illumina ${ }^{\circledR}$, and EBSCO ${ }^{\circledR}$ for references in text to "gap analysis project," "gap analysis program," “gap analysis' and GIS," and "USGS and gap." This search resulted in 2,058 unique publications after all duplicates were removed from the list. We excluded publications if the content focused on the program itself, gap analysis methods, or a specific GAP project because we were interested only in use of GAP data. We excluded all references that were published in the GAP Bulletin and all GAP Project Reports because our intention was to focus on how GAP data were used outside of the program. We included publications if the author(s) made a statement indicating they had used a dataset produced by GAP or indicated a use of a GAP dataset in a table or figure. We were unable to locate copies of 138 publications and therefore could not make a determination regarding the use of GAP data for those publications. The final list of references citing GAP data includes 646 publications. 
Most authors were listed on only one publication, and only a few authors received authorship credit on more than one publication in the set. This set of references is not characterized by a small set of authors who publish repeatedly using GAP data. The authorship pool consists of many authors. The publication outlet was primarily journal articles, although there were conference presentations, student dissertations and theses, book chapters, and reports. We summarized the titles of the journals and the number of publications appearing in each journal. Publications using GAP data appeared in 161 journals. The topics addressed by the journals were quite diverse and included wildlife (Journal of Wildlife Management), conservation (Biological Conservation), weather (Weather and Forecasting), and infectious diseases (Emerging Infectious Diseases). We categorized the publications based on the year of publication with separate counts for use of state, regional, and national data. The year of publication ranged from 1994 to 2011, and state datasets were cited more frequently than regional or national datasets. This is not surprising given that the state datasets have been available for a longer period of time. Among the types of data provided by GAP, the most frequently used in the published literature was land-cover data. We analyzed the frequency with which each dataset was used based on the project developing the data (state, region, or national) and the type of data. The most frequently used dataset was land cover from the California Gap Project. We calculated the durability of data based on the earliest and most recent publication dates for publications that used GAP data from each project. The length of time that a dataset is used after it is released can be used as one indicator of the usefulness of the data. The durability of data varied, and some of the datasets had a length of use that exceeded 10 years.

The next step was to summarize the comments about GAP data from these publications. We searched the text of each publication for statements regarding GAP data. We marked the statements that referred to data or maps - ignoring those that referred to the program itself or GAP projects and not data - and pulled them into a database. We reviewed the statements and grouped them into categories based on the theme of the statement. The themes in the main categories were the following: description of data, how data were used, critiques, comparisons, commentary, and reference to GAP data.

The statements included in the description of data category were statements that described which GAP dataset was used in the publication. The category of how data were used included methodological descriptions of GAP data such as transformations made to the dataset, descriptions of how GAP data were compared to other datasets, and descriptions of how GAP data fit the purpose of the study. The statements identified as critiques addressed different issues including accuracy, error, how GAP data were lacking, limits to the data, and utility of GAP data. The statements included in the category of comparisons described conclusions drawn as to how GAP data compared to other data. GAP data were described as comparing favorably, unfavorably, favorably in some aspects yet unfavorably in others, and equivalently to other datasets. Commentary statements regarding GAP data were mostly favorable. Some of the commentary statements indicated that potential issues with GAP data were mitigated in some situations. For example, the state datasets are older which can pose a problem in some applications. However, in cases in which landscape change is the focus of study, the availability of older datasets is beneficial. In those cases, the datedness of the data is mitigated by the purpose of the study. Finally, the reference to GAP data category includes statements that describe or refer to a dataset but not specifically the use of a dataset.

We conducted a bibliometric analysis to gain additional understanding about the publications that used GAP data. The results of bibliometric analyses can be used as a component in the performance evaluation process for a research program (Campbell and others, 2010; Trochim and others, 2008; Verbeek and others, 2002) and in science policy and planning (Irvine and others, 1987). We used the journal impact factors for those publications appearing in journals, and citation counts for all 
publications. The journals were associated with 34 disciplines as categorized by the Web of Science Journal Citations Report ${ }^{\circledR}$. The journals publishing articles that used GAP data had a variety of journal impact factors - which relate to the average frequency articles from that journal are cited by other publications. Forty percent of the journals were rated in the top quartile within their respective disciplines. This indicates that GAP data are used in publications that appear in journals considered to be at the top in their field.

As part of the bibliometric analysis, we researched how frequently each of the publications using GAP data was cited in other publications. We used Web of Science to determine the citation count for each publication. Older publications tend to be cited more, however, the most frequently cited publication using GAP data was published in 2004. We cross-referenced the publication citation counts with the datasets used in the publications. The datasets included in the most publications were not necessarily those in the publications with the most citations. The dataset associated with publications receiving the highest number of citations was the Utah land-cover dataset. The citation rates may indicate the degree of secondary diffusion of information regarding GAP data. The publications that used GAP data, identified their use of GAP data, and wrote about use of GAP data increased the visibility of these datasets. The citation counts for those publications provided an index of how many others were introduced to GAP data based on their citation of the publications using GAP data.

In summary, the review of published literature that cites a use of GAP data yields several conclusions. First, GAP data are being used by a wide variety of researchers. Second, the comments made in the text of the publications regarding GAP data included favorable comments as well as specific critiques. Finally, GAP data are used in publications that appear in many high-impact journals.

The results of this published literature search had several implications for the survey of GAP users. First, specific issues that emerged from the qualitative analysis of statements regarding GAP data in these publications were used to generate questions for the survey. Specifically, the survey included questions regarding the issues of accuracy, error, to what extent issues of accuracy and error are problematic to the user, what GAP data lack that would be useful, how GAP data compare to other datasets, and what transformations to GAP data are required to make the data useful to the user. Second, given the wide range of datasets used and great variety in journals and disciplines in which the publications appeared, the survey was designed as an adaptive survey so that respondents were asked only questions that pertained to the dataset with which they were most familiar. Finally, the authors of the publications were clearly individuals who have used GAP data and their names were added to the list of potential survey respondents.

\section{Background}

The Gap Analysis Program (GAP) of the U.S. Geological Survey (USGS) has been operational since 1989. GAP provides spatial data for use as a framework to make assessments regarding how well biodiversity is protected and to evaluate what aspects of biodiversity need greater protection. Among the program goals are providing "information to the public and those entities charged with land use research, policy, planning, and management," and "build[ing] institutional cooperation in the application of this information to state and regional management activities." To this end, GAP produces and provides the following types of datasets: land cover; predicted distributions of vertebrate species; land stewardship (ownership and conservation status); and analysis data synthesizing the three aforementioned datasets. The Gap Program does not charge a fee to download the data. The initial datasets were created at the state level; Puerto Rico was included as a state project. These datasets are archived on the GAP website. More recent datasets have been assembled at regional data levels. Specifically, regional data are available for three regions: Southwest (Arizona, Colorado, New Mexico, 
Nevada, Utah); Southeast (Alabama, Florida, Georgia, Kentucky, Mississippi, North Carolina, South Carolina, Tennessee, Virginia); and Northwest (Idaho, Montana, Oregon, Washington, Wyoming). However, not all types of data are currently available for all regions. National data for land cover and stewardship became available in 2009. Some national species distribution models and ranges are available and additional species models will be added to the website as they become available.

In Federal fiscal year 2007, the Policy Analysis and Science Assistance branch of the USGS contracted with GAP to conduct a systematic evaluation. GAP has data development programs for both terrestrial and aquatic species. At the request of GAP, we focused our evaluation on the data produced for terrestrial species. The intent of the evaluation was to assess the impacts that GAP products-the datasets it produces and distributes - have on the individuals who use the products (GAP users) and on conservation of biodiversity. The main component of such an evaluation is a data collection process using a survey (Rossi and others, 2004) designed to measure the extent to which GAP is achieving its stated goal of "keeping common species common" through the conservation of biodiversity. The results of this survey will be used by GAP administrators and staff to evaluate past performance of the program and to strategically plan changes to the current approach. Changes in the existing approach to developing and providing data may be necessary to best meet the needs of current GAP users and to expand the number of GAP users. The survey is the key piece of the evaluation project so it must be carefully designed. To support and inform survey development, we collected information from several outlets. We searched the published literature for studies making use of GAP data, reviewed the literature on use of geographic information system (GIS) data for decisionmaking and related topics, and conducted two discussion groups that included GAP users. In this report, we describe our study of the published literature using GAP data. In addition to providing direction for development of survey questions, the review of published literature makes a unique contribution by identifying how GAP is described in the public realm. We define the public realm as documents and publications that are accessible to the public in hardcopy or electronically over the internet. Information regarding the data produced by GAP that is publicly available increases awareness of the program, the data it provides, and how the data can be used. Our goal was to understand the external characterization of GAP as opposed to how it is characterized internally by GAP staff and cooperators. Focusing on the external view of GAP is more likely to result in a characterization of GAP that is independent and bias-free.

We describe the search process used to identify publications citing GAP data, the characteristics of these publications including which datasets were cited, the results of a qualitative study of comments regarding GAP data in the publications, and the results of a bibliometric analysis of these publications.

\section{Reference Search Methods}

In any study of published literature, use of multiple databases maximizes the potential of obtaining a representative set of literature (Okubo, 1997). A study of the overlap between journals covered by Web of Science ${ }^{\odot}$ and Scopus ${ }^{\circledR}$ demonstrated that the two databases have some overlap but provide substantial unique coverage (Gavel and Iselid, 2008). The two databases overlap in their journal coverage but Scopus includes more publication outlets of other types such as conference presentations (Moed, 2009). When databases cover different ranges of publication dates, searching in multiple databases can result in a set of search results that cover a longer range of time, rather than a set of results limited by the beginning and end date of a single database. The databases searched began their collection of citations in different years; the earliest year covered was 1971.

We searched Web of Science, Scopus, Google Scholar, CSA Illumina ${ }^{\circledR}$ and EBSCO ${ }^{\odot}$. CSA Illumina and EBSCO enable more efficient searching because searches of multiple databases can be performed simultaneously. In CSA Illumina, we searched the following databases: Aquatic Sciences and 
Fisheries Abstracts, Biological Sciences, Biology Digest, Digests of Environmental Impact Statements, Meteorological and Geoastrophysical Abstracts, NTIS, Plant Science, and Zoological Record. In EBSCO, we searched the following databases: Agricola, Biological Abstracts, CAB Abstracts, Fish and Fisheries Worldwide, GeoRef, and Wildlife Ecology. We used the search terms "gap analysis project," "gap analysis program," "'gap analysis' and GIS," and "USGS and gap." We used the first one thousand results for each of the searches in Google Scholar. Even when a search returns more than one thousand results in Google Scholar, only the first thousand can be viewed. We combined the results from all searches into a master list that included 5,507 publications. There were 2,058 unique publications after all duplicates were removed from the list.

We reviewed each entry on the list of 2,058 publications and applied a set of inclusion and exclusion criteria to create a final list of publications to include in subsequent phases of this review. We included publications if the author(s) made a statement indicating they had used a dataset produced by GAP or cited GAP data in a table or figure. We excluded publications if they met any of the following criteria:

- the content of the publication focused on the GAP program, gap analysis methods, or a specific GAP project,

- the publication outlet was the GAP Bulletin,

- the publication was a GAP project report or described a project report,

- the authors noted the GAP program as a data source but did not make use of GAP data,

- the content of the publication described using gap methodology, but not GAP data, or

- the content addressed aquatic GAP - the focus of this project is the terrestrial GAP data.

Although we intended to focus on the use of GAP data and not publications by or about the program, we did not automatically exclude publications authored by former and current GAP staff. If the content of the publication focused on the program, a GAP project, or gap analysis methods, the publication was deleted from the list. If the publications appeared to be applications of GAP data, they were included on the list.

If we could not determine if a reference should be included or excluded based on the title and abstract, we reviewed the entire text of the publication if it was accessible. We could not access the text for 138 publications and were unable to determine if those publications included use of GAP data. The final list of references citing GAP data includes 646 publications. These publications are included in the list of references and marked with an asterisk.

\section{Limitations of Literature Search Methods}

Because of the time lag in the publishing process, the more recent regional and national datasets are less likely to be used and cited in published literature. The state datasets are older and have been available for longer periods of time and therefore are more likely to have been used and cited in published research. This reality should temper conclusions regarding the quality or usefulness of the datasets. A conclusion that the regional datasets are less used and therefore less useful because they are cited in fewer publications would not be an appropriate one.

GAP produced the datasets used by the researchers who wrote these publications. There may have been uses of GAP data to create maps or documents that have not been published because they were used exclusively for management of natural areas. The use of publications citing GAP data provides what is likely to be an incomplete and conservative depiction of the actual range of GAP data use. However, these publications provide information that cannot be addressed by other methods. Publications include public statements about GAP data, and identify uses and users of GAP data that might not be identified through other means. 
We cannot claim that this list includes all research publications that have cited GAP data. Compiling a complete list of publications generated by a program is a common concern when using publications as part of a program evaluation (Narin and Hamilton, 1996). It is difficult to know the completeness of the compiled list. One concern regarding constructing the bibliography for a bibliometric analysis is that the available information about publications depends on the recordkeeping practices of others. Even a database that draws from a wide range of sources is likely to omit some publication records. If the researchers used different terminology or if the publication outlet was not indexed in the databases we searched, our search strategy would not have identified all publications using GAP data. We excluded publications that seemed to primarily focus on specific GAP projects. Other readers or the publication authors may believe that these publications were examples of use of GAP data that should have been included in our final set of publications. An additional concern is the amount of time required to construct a thorough bibliography. The practical constraints of time and other resources such as funding and access to publication databases will affect the completeness of the final bibliography. We used the most thorough search strategy given the realistic constraints of time and resources. We applied our inclusion and exclusion criteria as consistently as possible. We have identified a set of publications that can be considered an adequate sample of publications citing GAP data that is suitable for the summary analyses conducted.

\section{Data Recording Strategy}

For each publication we reviewed, we created a data record that included specific information regarding the publication. The record included the citation, list of author names, the source of the publication (such as journal title, book title, conference title), the type of publication outlet (journal article, book, conference presentation, student paper, and report), year of publication, project that produced the data (state, regional, or national), type of data used (land cover, predicted species distribution, stewardship, analysis), and quotations from the publication in which GAP data are mentioned. If there was any question regarding any of what data should be recorded, we entered "unknown" into the data field. If the information was unclear, we did not assume and record data based on those assumptions. In some cases, authors did not specifically state which type of dataset from GAP was used. In other cases, authors indicated a type of data, such as land cover, but did not indicate if it came from state or regional projects.

\section{Summary of Publication Characteristics}

The set of publications citing GAP data on which we based our analyses included 646 publications. We summarized the publications based on authorship, publication outlet, year of publication, and dataset characteristics.

\section{Authors}

One of the issues addressed in the evaluation of GAP is the influence of the program. One method of assessing the breadth of the program's influence is to determine if use of GAP data can be characterized as repeated use by a limited group of users or infrequent use by a broader set of users. We used this set of publications to ascertain if evidence existed that would suggest one characterization over the other. If GAP data are used repeatedly by a limited group of users, we expect that authors will be credited on multiple publications in this sample. If GAP data are used by a broader set of users, we expect that most authors will be credited on fewer publications. In order to address this issue, we created a list of authors who received any level of authorship credit (first author, second author, etc.) in this set 
of publications. We counted the number of different publications on which an author received credit. There were 1,599 individuals listed as authors in this set of publications. The number of publications on which authors received credit ranged from 1 to 13. The percent of authors receiving credit on each number of publications is depicted in figure 1 .

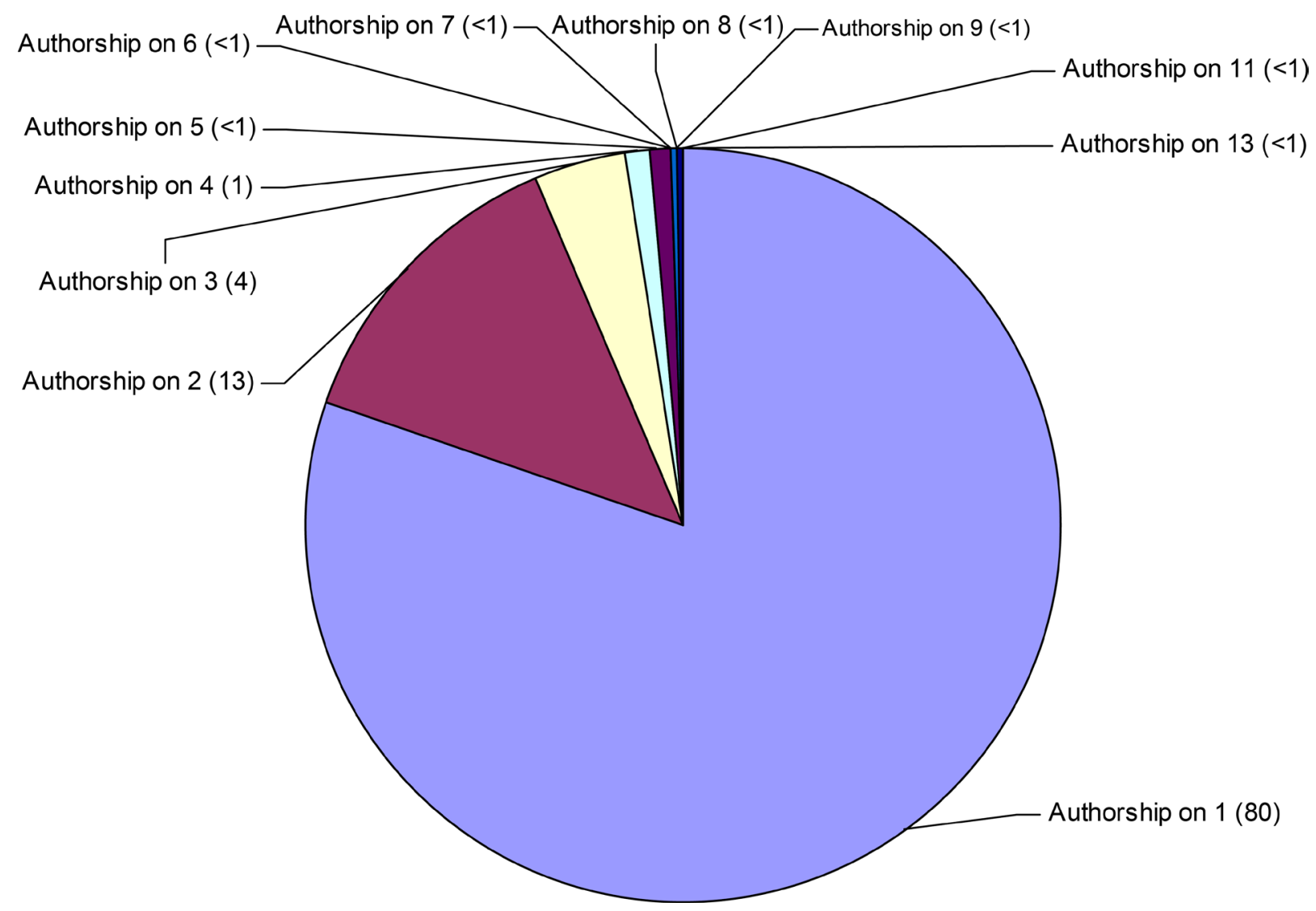

Figure 1. Proportion of authors receiving credit categorized by number of publications. Percent of authors in each category is provided in parentheses.

The majority of authors ( 80 percent) were credited on only one publication, which suggests GAP data are used less frequently by a wide range of users. Only 6.5 percent of authors were listed on three or more publications.

\section{Publication Outlet}

Identifying the means through which information about GAP is disseminated is another approach to understand the influence of GAP. We categorized each publication according to the type of outlet based on five categories: book, conference presentation, student paper, report, and journal article. The category labeled "book" includes chapters in edited books and conference proceedings. The reason for including conference proceedings in this category is that papers published in proceedings often undergo a more rigorous editorial process and are available in a more durable format than other types of conference presentations. The "book" category contains 117 publications. The category labeled 
"conference presentation" includes presentations, posters, papers identified as being presented in some way at a conference, and conference presentation abstracts. This category contains 24 publications. The category labeled "student paper" includes dissertations, theses, undergraduate honors and capstone papers, and papers written as part of required coursework. This category contains 55 publications. The category labeled "report" includes publicly available reports by federal, state, or local agencies, and nonprofit and for profit organizations. This category contains 108 publications. The majority of publications, 342, were from journals. The percent of publications from each outlet type is shown in figure 2 .

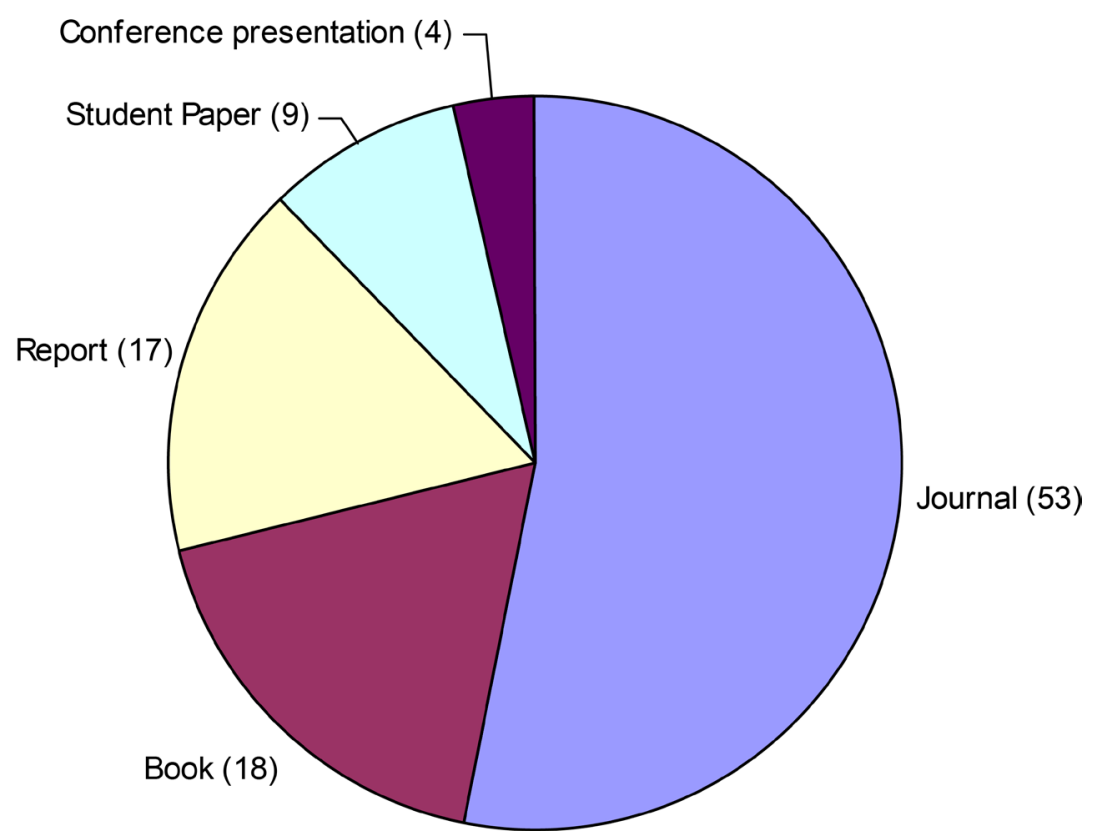

Figure 2. Percent of publications by outlet type. Percent of publications in each category is provided in parentheses.

For the publications included in the report category, we identified the type of organization producing the report. Government agencies produced 32 (30 percent) of the reports. Educational institutions produced 31 ( 29 percent) of the reports. Nonprofit organizations produced 27 ( 25 percent) of the reports. Organizations that operate for profit produced 13 (12 percent) of the reports. We could not identify the type of organization that produced five of the reports because the identifying information was limited.

We identified the type of student paper for the 55 publications in that category. The student papers included 34 Master's theses (62 percent), 10 Doctoral dissertations (18 percent), and the remaining 11 (20 percent) were other student papers.

Because so many of the publications were from journals, we examined the publications from journals more closely by conducting a bibliometric analysis. The bibliometric analyses are described in a subsequent section of this report. We provide a list of the 161 journal titles and number of articles from each of those journals as part of the description of this set of publications citing GAP data. This information is provided in table 1 . 
Table 1. Journal title and number of articles from each journal.

\begin{tabular}{|c|c|}
\hline Journal Title & Number of Articles \\
\hline Journal of Wildlife Management & 20 \\
\hline Conservation Biology & 17 \\
\hline Ecological Applications & 14 \\
\hline Landscape Ecology & 9 \\
\hline Photogrammetric Engineering \& Remote Sensing & 9 \\
\hline Wildlife Society Bulletin & 8 \\
\hline Biological Conservation & 7 \\
\hline Environmental Monitoring and Assessment & 6 \\
\hline Natural Areas Journal & 6 \\
\hline Environmental Management & 5 \\
\hline Journal of Mammalogy & 5 \\
\hline Madroño-California Botanical Society & 5 \\
\hline Molecular Ecology & 5 \\
\hline Remote Sensing of Environment & 5 \\
\hline Southwestern Naturalist & 5 \\
\hline Monthly Weather Review & 4 \\
\hline American Journal of Tropical Medicine and Hygiene & 3 \\
\hline American Midland Naturalist & 3 \\
\hline Animal Conservation & 3 \\
\hline Auk & 3 \\
\hline Diversity and Distributions & 3 \\
\hline Ecography & 3 \\
\hline Environmental Modelling \& Software & 3 \\
\hline Forest Ecology and Management & 3 \\
\hline International Journal of Remote Sensing & 3 \\
\hline Journal of Arid Environments & 3 \\
\hline Journal of Forestry & 3 \\
\hline Journal of Medical Entomology & 3 \\
\hline Journal of the American Water Resources Association & 3 \\
\hline Landscape and Urban Planning & 3 \\
\hline North American Journal of Fisheries Management & 3 \\
\hline Southeastern Naturalist & 3 \\
\hline Wetlands & 3 \\
\hline American Fisheries Society Symposium & 2 \\
\hline Applied Geography & 2 \\
\hline Atmospheric Environment & 2 \\
\hline Biodiversity and Conservation & 2 \\
\hline Condor & 2 \\
\hline Ecohydrology & 2 \\
\hline Ecological Indicators & 2 \\
\hline
\end{tabular}


Table 1. Journal title and number of articles from each journal.-Continued

\begin{tabular}{|c|c|}
\hline Journal Title & Number of Articles \\
\hline Ecological Modelling & 2 \\
\hline Ecology and Society & 2 \\
\hline Ecosystems & 2 \\
\hline Emerging Infectious Diseases & 2 \\
\hline Forest Policy and Economics & 2 \\
\hline Forest Science & 2 \\
\hline Global Change Biology & 2 \\
\hline Global Ecology and Biogeography & 2 \\
\hline Journal of Coastal Research & 2 \\
\hline Journal of Soil and Water Conservation & 2 \\
\hline Journal of the Arkansas Academy of Science & 2 \\
\hline Journal of Vegetation Science & 2 \\
\hline Occasional papers, Museum of Texas Tech University & 2 \\
\hline Oikos & 2 \\
\hline PloS ONE & 2 \\
\hline Professional Geographer & 2 \\
\hline Quaternary Research & 2 \\
\hline Soil Science Society of America Journal & 2 \\
\hline Southern Journal of Applied Forestry & 2 \\
\hline Studies in Avian Biology & 2 \\
\hline Transactions of the Kansas Academy of Science & 2 \\
\hline Ursus & 2 \\
\hline Western Journal of Applied Forestry & 2 \\
\hline Wildlife Biology & 2 \\
\hline Wilson Journal of Ornithology & 2 \\
\hline Agricultural Water Management & 1 \\
\hline Ambio & 1 \\
\hline American Journal of Enology and Viticulture & 1 \\
\hline Annals of the Association of American Geographers & 1 \\
\hline Applied Vegetation Science & 1 \\
\hline Biological Invasions & 1 \\
\hline Bioresource Technology & 1 \\
\hline BioScience & 1 \\
\hline California Agriculture & 1 \\
\hline Canadian Journal of Fisheries and Aquatic Science & 1 \\
\hline Climatic Change & 1 \\
\hline Computing in Science and Engineering & 1 \\
\hline Conservation and Society & 1 \\
\hline Conservation Genetics & 1 \\
\hline Digital Soil Mapping & 1 \\
\hline Ecological Monographs & 1 \\
\hline
\end{tabular}


Table 1. Journal title and number of articles from each journal.-Continued

\begin{tabular}{|c|c|}
\hline Journal Title & Number of Articles \\
\hline Ecological Research & 1 \\
\hline Ecology & 1 \\
\hline Ecology Letters & 1 \\
\hline Endangered Species Update & 1 \\
\hline Energy Policy & 1 \\
\hline Environmental Entomology & 1 \\
\hline Environmental Geology & 1 \\
\hline Environmental Science and Pollution Research & 1 \\
\hline Environmetrics & 1 \\
\hline Evolution & 1 \\
\hline Fire Ecology & 1 \\
\hline Forestry Chronicle & 1 \\
\hline Freshwater Biology & 1 \\
\hline Frontiers in Ecology and the Environment & 1 \\
\hline Geoderma & 1 \\
\hline Geographical Review & 1 \\
\hline Geoscience and Remote Sensing Symposium Proceedings & 1 \\
\hline Geospatial Health & 1 \\
\hline GIScience and Remote Sensing & 1 \\
\hline Great Basin Naturalist & 1 \\
\hline Great Plains Research & 1 \\
\hline Human and Ecological Risk Assessment & 1 \\
\hline Human Dimensions of Wildlife & 1 \\
\hline Human Ecology Review & 1 \\
\hline Hydrobiologica & 1 \\
\hline Hydrological Sciences Journal & 1 \\
\hline Insecta Mundi & 1 \\
\hline Integrated Environmental Assessment and Management & 1 \\
\hline International Journal of Biodiversity and Conservation & 1 \\
\hline International Journal of Wildland Fire & 1 \\
\hline Invasive Plant Science and Management & 1 \\
\hline IUCN Otter Specialist Group Bulletin & 1 \\
\hline Journal of Applied Ecology & 1 \\
\hline Journal of Applied Remote Sensing & 1 \\
\hline Journal of Biogeography & 1 \\
\hline Journal of Conservation Planning & 1 \\
\hline Journal of Environmental Engineering & 1 \\
\hline Journal of Environmental Planning and Management & 1 \\
\hline Journal of Environmental Quality & 1 \\
\hline Journal of Great Lakes Research & 1 \\
\hline Journal of Insect Conservation & 1 \\
\hline
\end{tabular}


Table 1. Journal title and number of articles from each journal.-Continued

\begin{tabular}{|c|c|}
\hline Journal Title & Number of Articles \\
\hline Journal of Land Use Science & 1 \\
\hline Journal of Raptor Research & 1 \\
\hline Journal of Remote Sensing & 1 \\
\hline Journal of the North American Benthological Society & 1 \\
\hline Journal of the Torrey Botanical Society & 1 \\
\hline Journal of Water Resources Planning and Management & 1 \\
\hline Kalmiopsis & 1 \\
\hline Lake and Reservoir Management & 1 \\
\hline Marine Geodesy & 1 \\
\hline Marine Pollution Bulletin & 1 \\
\hline McNair Research Journal & 1 \\
\hline Northeastern Naturalist & 1 \\
\hline Northern Journal of Applied Forestry & 1 \\
\hline Northwest Science & 1 \\
\hline Northwestern Naturalist & 1 \\
\hline Ocean Engineering & 1 \\
\hline Oecologica & 1 \\
\hline Parks & 1 \\
\hline Peromyscus Newsletter & 1 \\
\hline Physics and Chemistry of the Earth & 1 \\
\hline Proceedings of the National Academy of Sciences & 1 \\
\hline Pure and Applied Geophysics & 1 \\
\hline Rangeland Ecology \& Management & 1 \\
\hline Sensors & 1 \\
\hline The Bryologist & 1 \\
\hline Transactions in GIS & 1 \\
\hline Transactions of the American Entomological Society & 1 \\
\hline Transactions of the American Fisheries Society & 1 \\
\hline Transactions of the ASABE & 1 \\
\hline Urban Ecosystems & 1 \\
\hline Water Resources Research & 1 \\
\hline Water, Air, and Soil Pollution & 1 \\
\hline Waterbirds & 1 \\
\hline Weather and Forecasting & 1 \\
\hline Western North American Naturalist & 1 \\
\hline Wildfowl & 1 \\
\hline Wildlife Biology in Practice & 1 \\
\hline Wyoming Open Spaces Bulletin & 1 \\
\hline Yearbook of the Association of Pacific Coast Geographers & 1 \\
\hline
\end{tabular}




\section{Year}

GAP has been producing data for more than a decade. State GAP datasets predate the regional and national datasets. One concern regarding GAP data from the state projects is that the datasets are out-of-date and may no longer be as useful. Another view is that the historical perspective provided by older datasets is invaluable, and these datasets will continue to be used particularly in light of the evolution of landscapes and the threat of climate change. We categorized the publications based on the year of publication with separate counts for use of state, regional, and national data (figure 3 ).

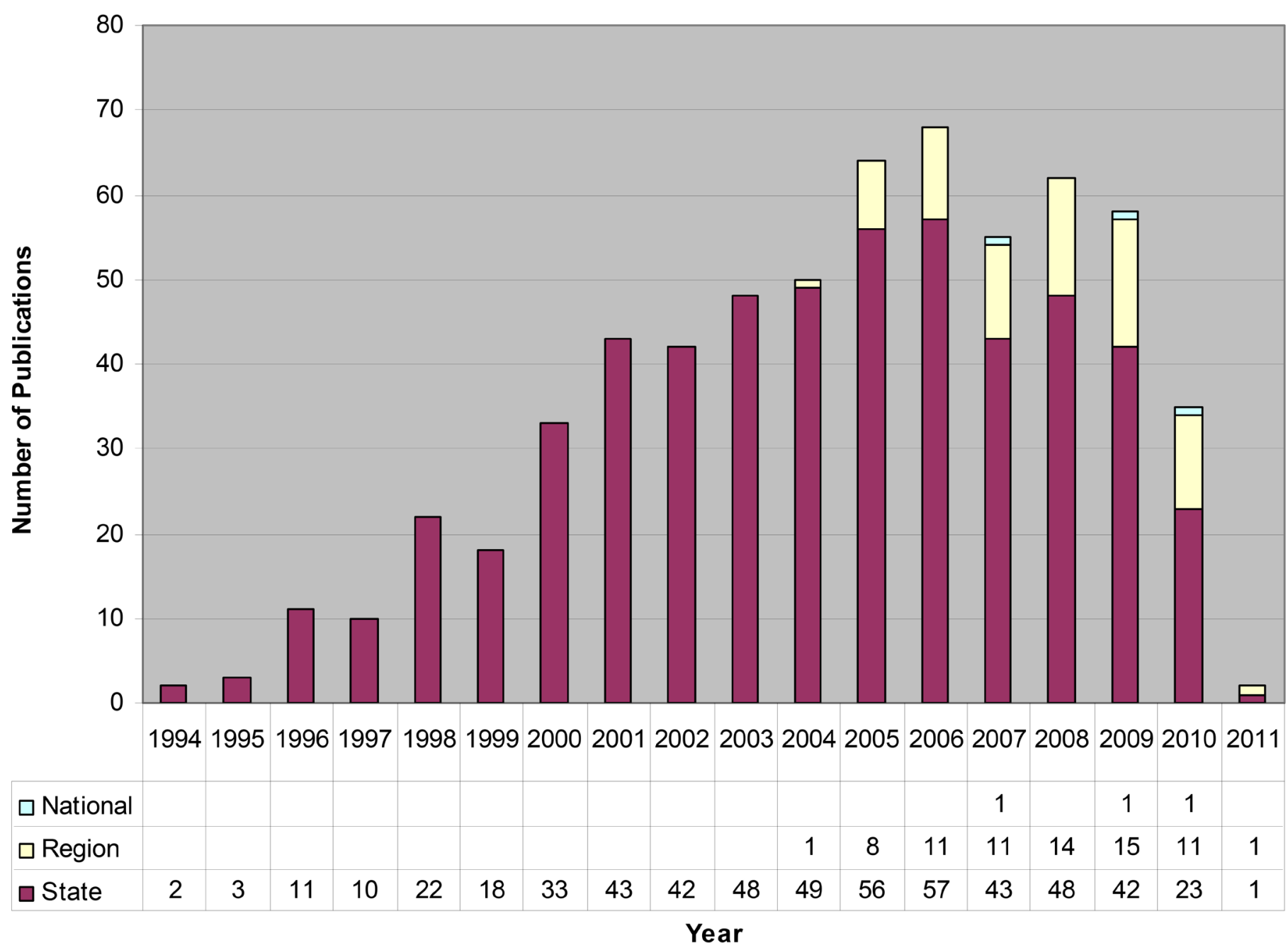

Figure 3. Number of publications citing state, regional, and national GAP data by year. The data for 2011 includes only the month of January. 


\section{Dataset}

In addition to the distinction between state, regional, and national datasets, there are multiple datasets produced for each project: land cover, predicted species distributions, stewardship, and analysis. The analysis dataset synthesizes the land-cover, predicted species distributions, and stewardship datasets. We noted which datasets were used in each publication. Some publications used multiple datasets. There were publications in which the authors stated that data from GAP were used but did not provide sufficient detail for us to confidently determine which dataset was used.

First, we counted the number of publications using each type of data. If a publication used the land-cover datasets from two adjoining states, the publication would count as one publication using land-cover data. If a publication used a land-cover dataset and a predicted species dataset, it would count as one publication using land cover and one publication using predicted species data. The level of analysis was the publication. The number of publications using each type of dataset is depicted in figure 4. Land-cover data was used in 73 percent of the publications. Because some of the publications used more than one type of dataset, the total number of publications depicted in the pie chart in figure 4 exceeds the number of publications in the dataset.

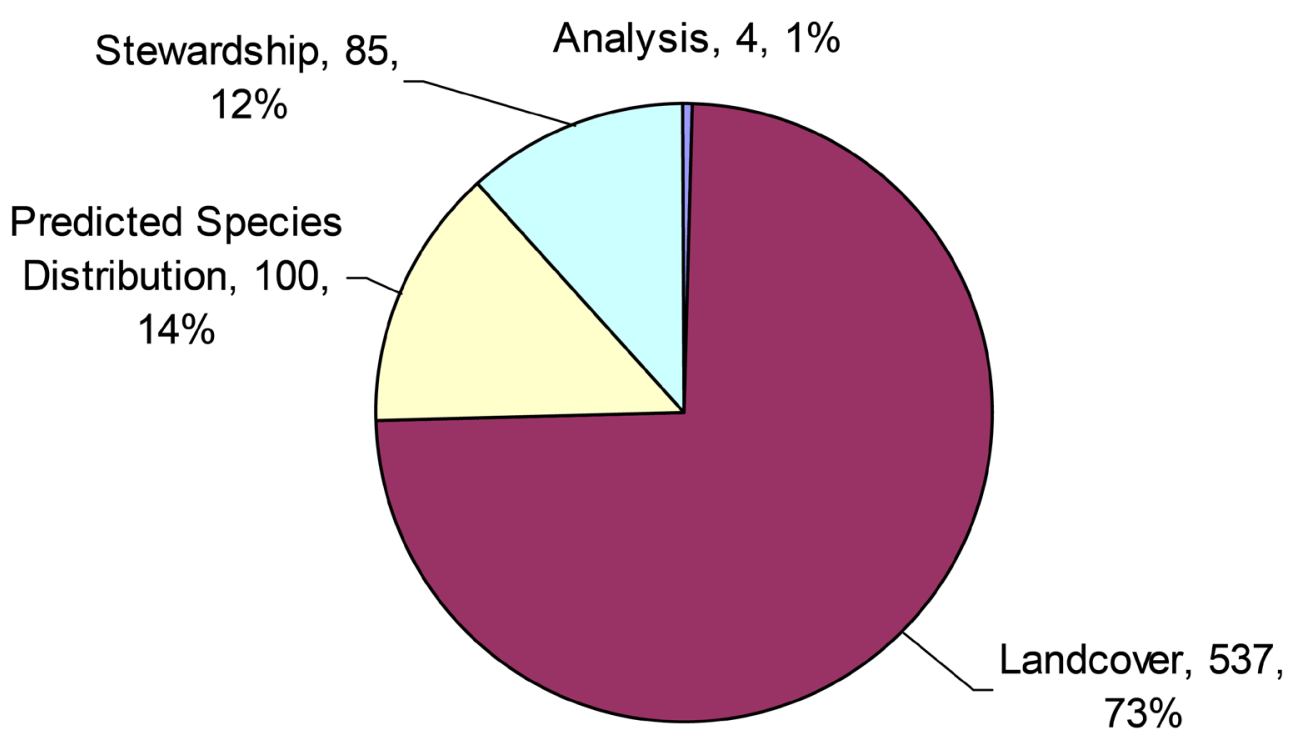

Figure 4. Number and percent of publications using each type of dataset.

Second, we counted the number and type of datasets used in each publication. For example, if a publication used the land-cover datasets from two adjoining states, that counted as two uses of landcover datasets. The level of analysis was the dataset. Figure 5 provides the number of each type of dataset used by year of publication. 


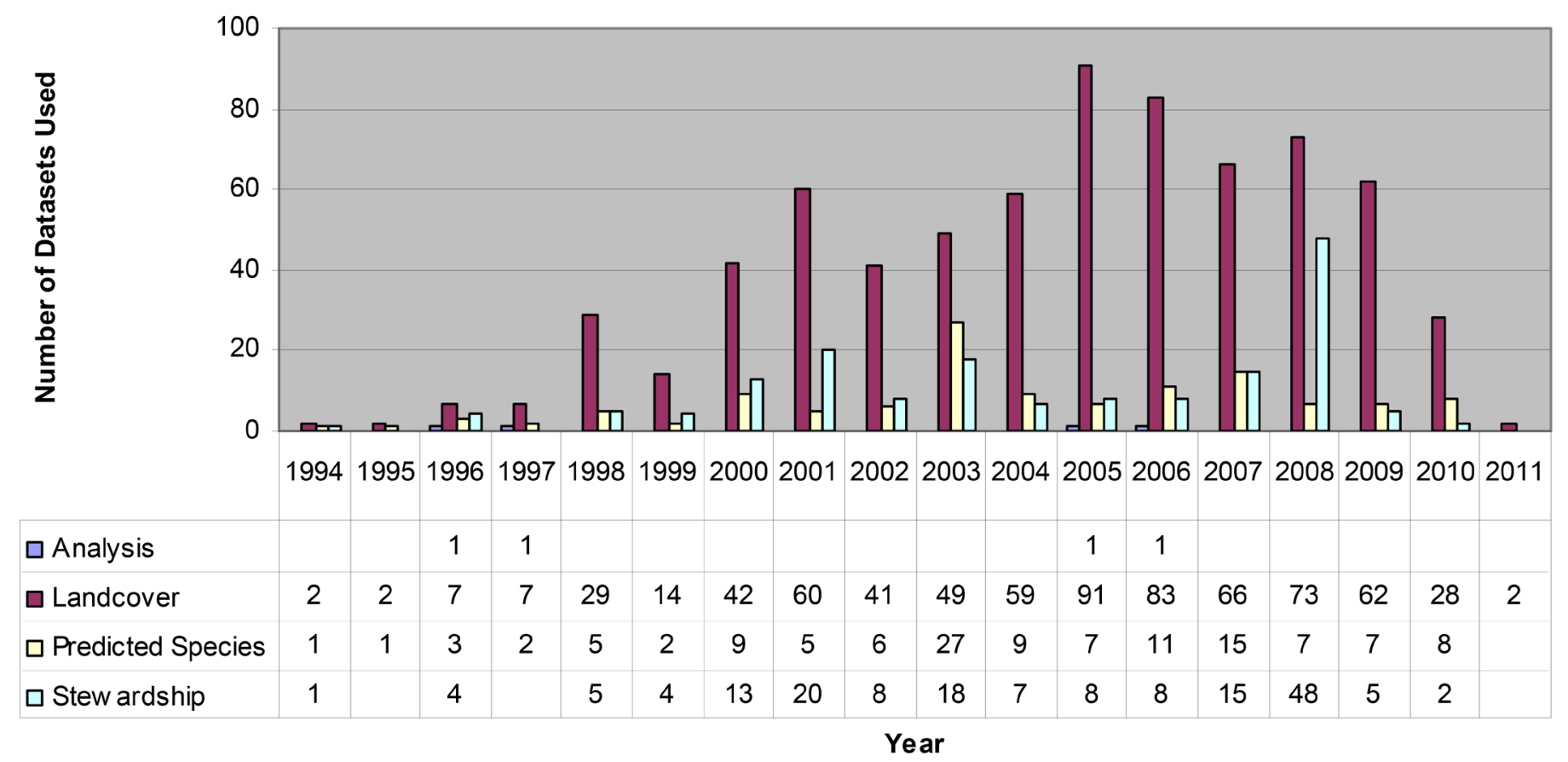

Figure 5. Number of datasets used by year of publication. The data for 2011 includes only the month of January.

Each type of dataset is provided within the state, regional, and national projects. We counted the datasets used based on the state, regional, or national project as well as the type of data. To identify the project producing the data, we used the two letter abbreviation for states, PR for Puerto Rico, and the acronyms SWReGAP (Southwest regional GAP), SEGAP (Southeast GAP), and NWGAP (Northwest GAP). In figure 6, we provide the number of times each dataset was used in the group of publications used in this study. The datasets are grouped by state, region, or national level, and each type of data is depicted separately. The actual counts are provided when the number of times the dataset was used exceeds 10 . 


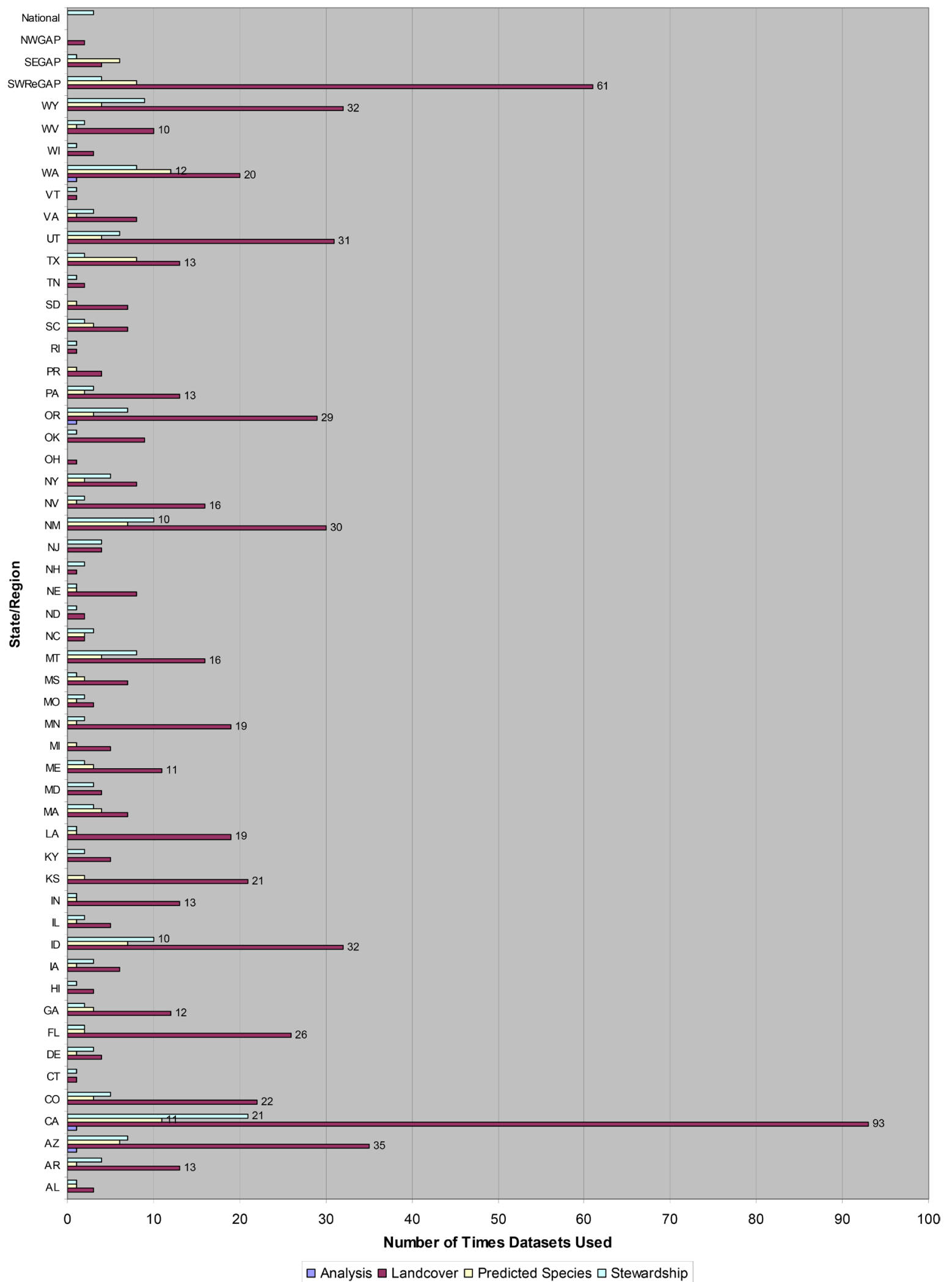

Figure 6. Frequency of use for each type of dataset, grouped by state, region, and national level. 
There is evidence of use of multiple types of data from most state and all regional projects. There were no citations of use of Alaska GAP data. As seen in figure 6, there were only four state projects from which the analysis type of dataset was used: Arizona, California, Oregon, and Washington. Land cover was the only type of data used from the Ohio state project. At the national level, the stewardship type of data was used. The frequency counts demonstrate how widely the use of GAP datasets varies. There are two datasets that have been cited more frequently than many of the other datasets: land cover from the state GAP for California - cited 93 times, and the land cover from the Southwest Regional GAP—cited 61 times.

\section{Durability of Datasets}

One of the goals of the evaluation project is to understand the usefulness of GAP data. One approach is to determine how long GAP data continue to be used. The length of time that people use GAP data after the data are released can be interpreted as an indicator of the usefulness of the data. We determined the durability of the datasets from each project by comparing the early and the most recent years of publications that used data from that project. The state, regional, and national projects were finished at different times, so the datasets became available during different years. The durability of data from each project is illustrated in figure 7. We included the year that the projects were completed with the illustration of the data durability. 


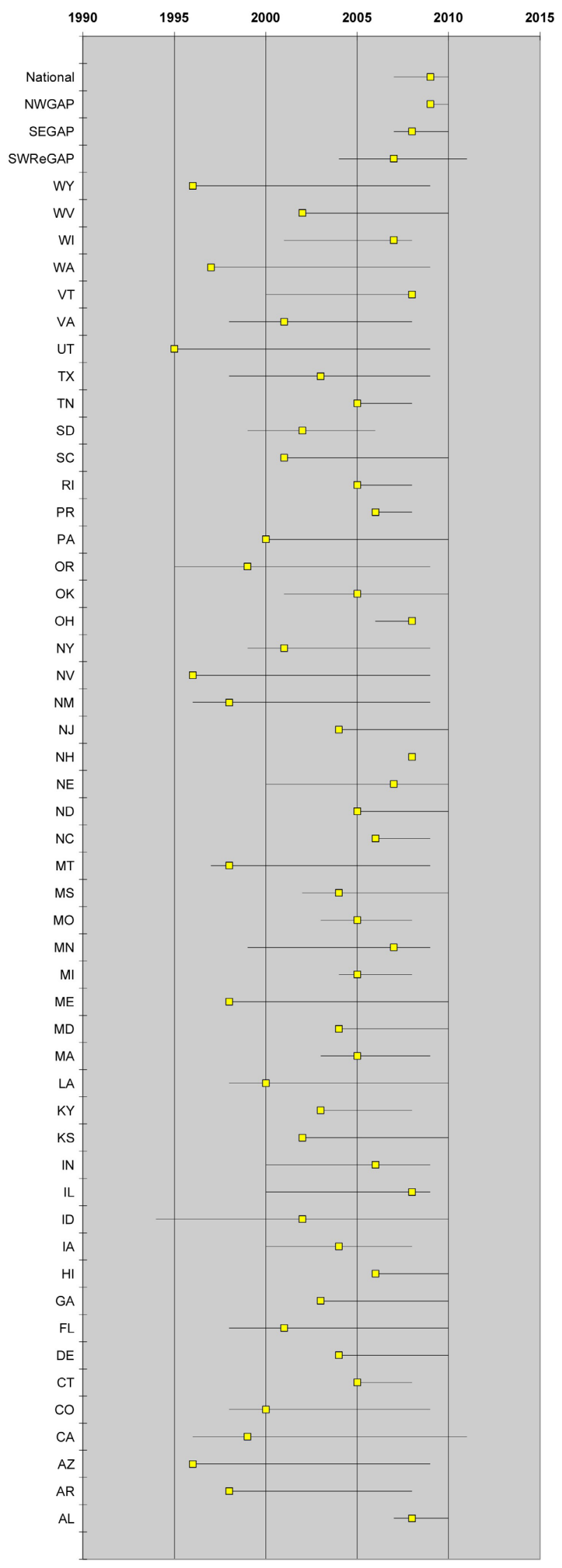

Figure 7. Durability of project datasets. The line for each project indicates the earliest and most recent years of publications included in this literature review. The official release date for the project data is indicated by a yellow point; this information was provided by the GAP office in Moscow, Idaho. 
Information for projects was included in this figure if all relevant data (year of earliest publication, year of most recent publication, project release year) were available for that project. The durability of the datasets varies. The datasets from some projects (for example, Arizona, California, Idaho, Louisiana, Maine, Montana, New Mexico, Nevada, Oregon, Utah, Washington, and Wyoming) have been used for more than 10 years. In the case of the New Hampshire state project, the year of the earliest publication, the year of the most recent publication, and the year of the project completion are the same-2008.

There are some publications that used GAP data prior to the project completion dates. There are two reasons for this. For many GAP projects, land-cover data are completed and released prior to the other datasets and prior to project completion (Jocelyn Aycrigg, GAP, oral commun., 2010). Therefore, the project completion date is after the actual release of the data for some projects. Second, several authors cited the use of "pre-release" GAP data. In those instances, the publication year can be earlier than the project completion year.

\section{Summary}

The summary of this set of publications indicates that most authors were credited on one publication, which suggests that a broad group of authors have made use of GAP data. In addition to this large group of infrequent users, there is a small group of authors who use GAP data repeatedly. There may be others - those who use the data for applied purposes - who also use GAP data. The publication outlets for this set of publications were primarily journals. The dominance of journals as a publication outlet may have resulted from the search methodology_-journals tend to be indexed in databases more often than book chapters or conference presentations. It may also result from the manner in which publications were excluded - applications of data may be more likely to be published in journals whereas descriptions of a program or method may be published as part of a book.

The types of journals that published articles citing GAP data were numerous and varied. The topics covered by the journals were quite diverse and included wildlife (Journal of Wildlife Management), conservation (Biological Conservation), weather (Weather and Forecasting), and infectious diseases (Emerging Infectious Diseases).

GAP data are time-sensitive in that they represent the land cover, stewardship, and predicted species distributions for a given area at a particular point in time. The state GAP datasets are based on older data than the regional GAP datasets. However, publications continue to be produced using GAP data from the state projects. This may indicate that GAP data have a longer than anticipated scientific life and that state datasets are not considered obsolete when regional or national datasets become available.

The land-cover type of data was most frequently used in publications. Used less frequently than land cover, predicted species distribution and stewardship datasets were utilized in 14 percent and 12 percent of publications respectively. The analysis data layer was rarely used.

The next step in the review of published literature was to summarize what the authors of these publications wrote regarding their use of GAP data.

\section{Qualitative Review of Comments}

We searched the text of each publication for statements regarding GAP data. We included all written language as the text of the publication. Figure and table headings and notes, acknowledgments, and reference lists were included in our review of a publication's text. We looked specifically for "gap" in the text and then determined if the statement referred to a dataset, a map, the national program, a 
project, or gap methodology. We marked the statements that referred to data or maps and pulled those statements into a database. When possible, we conducted this text search electronically using the search function. In the cases in which we could not obtain an electronic copy of the publication but could obtain a hard copy, we conducted the search manually. This search resulted in 1,376 statements. Each publication contributed at least one statement.

We reviewed this set of statements to identify emergent themes. Emergent themes are those that are derived from the set of statements; this is a bottom-up process. An alternative top-down approach would be to use a set of predefined categories and identify statements that belonged in each of those categories. This approach is limiting in that the categories are restricted to the predefined categorieswhat we would expect authors to state about GAP data. Because we were interested in comments generated by the authors rather than a select group of themes on which we expected authors to comment, we chose to use the bottom-up process of identifying emergent themes. Six broad themes emerged from these statements. The themes were description of data, how data were used, critiques, comparisons, commentary, and reference to GAP data. We describe each of these themes and provide examples. We report the number of statements in the theme and the number of publications that produced these statements, because the number of publications from which the statements are drawn provides context for understanding the number of statements. For example, accuracy of GAP data was cited as an issue in 29 statements. The context to interpret that theme is different if those statements came from 24 publications as opposed to if all 29 statements came from two publications. The latter case indicates that the accuracy issue was raised more frequently by a small number of authors.

\section{Description of Data}

The 559 statements in this category provide a description of the GAP data used by the authors. This was the largest category that emerged from the set of statements derived from the publications. All of the publications identified as citing GAP data included some statement about the use of GAP data. However, not all of them made statements that would have been included in this category. For example, if a citation of GAP data was included on the reference list only and made no other mention of GAP data in the text of the article, there would be no text that described the GAP data. The statements describing the data were from 430 of the 646 publications. In some cases, the description was concise. For example, Coops and Waring (2001a, p. 20) stated, "We obtained data on the spatial distribution of current vegetation from the Oregon Gap Analysis Program." Some publications, such as Singleton and others (2004), referenced GAP in the body of tables or in the acknowledgments only and not in the actual text of the document.

Other publications included additional information in the statement describing GAP data. For example, Boykin, Boykin, Stovall, and Whitaker (2008, p. 213) included a reason why the GAP data was used, "Because of the varying land management occurring within the Bootheel region, the only available land cover map was from the original New Mexico Gap Analysis Project (Thompson and others 1996)." Other statements included information on how the authors obtained GAP data. For example, Mawdsley (2001a, p. 434) wrote, "Two ARC/INFO interchange files were obtained by anonymous ftp from the Arizona National Biological Information Infrastructure website (http://usgsbrd.srnr.arizona.edu/nbii/index.html; ftp site ftp/srnr/arizona/edu): a high-resolution vegetation map of Arizona (the Arizona Gap Vegetation map), and a map indicating the boundaries of federally designated wilderness areas in Arizona." Authors also provided additional detail about the GAP datasets. Karlik and others (2003, p. 316) wrote, "The GAP database developed for California (found at the website http://www.biogeog.ucsb.edu/projects//gap/gap_home.html) is an ARC/INFO GIS 
database with plant species and vegetation class attributes associated with polygons within a defined geographic region."

\section{How Data Were Used}

Statements that describe how the GAP data were used were included in this category-525 statements from 316 different publications, the second largest category of statements. The descriptions of how data were used appeared in two forms - either statements regarding how data were used as part of the method or statements regarding how GAP data were used within the context of the intent of the study. Statements that indicated GAP data were used in combination with other datasets appeared in 184 statements from 151 publications. For example, Leu and others (2008b, unpaged) wrote, "Furthermore, because the Sagestitch map did not cover the entire study area, we appended missing agricultural lands using state GAP coverages for Arizona, New Mexico, California, Oregon, and western Washington ** *. We developed a grid of forest habitat from the 'Sagestitch' map (http://sagemap.wr.usgs.gov), and GAP landcover data (New Mexico, Oregon, Arizona, Washington, and California) by using a crosswalk among forest types (deciduous forest, mixed deciduous/conifer forest, conifer forest) and the input data layers (Table 1)." Webb and others (2010, p. 111) supplemented GAP data with a soils dataset, "We analyzed a land cover dataset (1991-1993) provided by the GAP project of Nebraska (Henebry et al. 2005) and a hydric soils dataset provided by the Natural Resources Conservation Service to describe landscape characteristics."

One hundred ten statements from 87 publications indicated that a transformation to GAP data was necessary. Transformations were in the form of excluding portions of datasets, reclassifying data, and converting data to a different format. Hopton and Mayer (2006, p. 4480) described their transformation of GAP data, "We combined the Gap analysis data for 130 polygons in West Virginia with other data sources using ArcView 3.3 (ESRI, Redlands CA). Six of the original 136 Gap analysis polygons (\#2, 14, 30, 48, 120, and 127) were excluded because none of the polygons extended into the state (Figure 1)." Hoffman and others (2008, p. 362) described how they condensed GAP data for their purposes, "Land cover data were gathered from the gap analysis program (GAP) data layer. GAP represents the highest spatial resolution, 30-m, land cover data for Nebraska. It consists of 20 different vegetation and land cover types. For this research, we condensed the GAP data into six major categories including native woodland, native grassland, wetland, cropland, water, and human inhabitance (i.e., towns and cities)." Roberson (2009, p. 21) described multiple transformations to the GAP data, "The location of all roads in the National Forest which was provided by the US Forest Service and the newest (2008) version of the South Carolina GAP land use classification dataset. First, the GAP land use classification was reclassified to a forest or non-forest dataset. Then the GAP land use classification was converted from a 30 meter cell size raster to a polygon feature class."

GAP data were used as foundational data for some studies. In these cases, GAP data did not seem to be a primary focus or tool in the study. Rather, GAP data were used as a basis for implementing or evaluating a strategy or method. Seventy-six statements from 68 studies indicated that GAP data were used in a foundational manner. For example, GAP data were used to select sampling sites by Martin and others (2007, p. 542) who stated, "Therefore, we sorted the 2,566 available grids by the percentage of shortgrass prairie contained in the grid based on data from the Colorado Gap Analysis Program and then systematically selected every 50th grid for sampling foxes (with a random starting point between 1 and 51)." Larson and Sengupta (2004) used GAP data to test a spatial decision support system (SDSS).

Other publications included descriptions of how GAP data were compared to other data. Ninetyone statements from 63 documents were made regarding comparisons to GAP data. These statements did not include the outcomes of the comparisons, or in other words, how GAP data fared when 
compared to other datasets. These statements described how GAP data were used in the comparison. For example, Howell and others (2008, p. 169) stated their objectives clearly, "to build empirical hierarchical models to predict the probability of occurrence for 9 avian species throughout the state of Georgia, USA, and to compare the performance of our models to the associated Georgia GAP Analysis (GAGAP) models." Similarly, Rice and others (2008, p. 49) stated their goal "to compare the GAP LCLU layer and a derived LCLU layer developed with landsat imagery specifically for the Trans-Pecos region of Texas." Some of these comparisons were specifically conducted to test or evaluate GAP data. Karlik and others (2003, p. 317) wrote, "A subsample of polygons was selected as a test for correctness of the geographic location of a specific GAP polygon; in other words, a test of the registration of the GAP database."

Other studies using GAP data framed their use of the data in terms of the intent or purpose of the study. Twenty-two statements from 19 publications indicated GAP data were used for studies regarding particular species. However, the predicted species distributions were not necessarily the GAP data used in these species studies. Adjemian and others (2006, p. 94) described their use of GAP data to study potential spread of plague by fleas, "Geographic information system (GIS) coverages of biological and environmental features were obtained from the California Gap Analysis Project (Santa Barbara, CA) and were used to develop the bioclimatic rules best associated with the observed locations of the fleas."

GAP data were also used in studies illustrating the use of these data for environmental planning and prediction. Eleven statements were made in eight studies that indicated this use of GAP data. For example, Crowe (1996, p. 232) wrote, "Another application of GAP and SCAG data was to prioritize planning related to at risk communities based on three criteria: amount of Protection Level III coverage, planned urban development coverage, and community size." Additionally, 16 statements from 14 publications described the use of GAP data to identify management and protection status for land that is of potential conservation interest. Hopton and Mayer (2006, p. 4492) describe their use of GAP data as, "While Gap analysis uses assembled data to focus mainly on small groups of species with shared habitat requirements that have little to no protection, we used the data to assess whether the current patterns of protected areas cover the areas with the highest species richness. As this method illustrated, some Gap analysis polygons of high species and habitat richness are not well represented by the current network of publicly held protected areas." Beal (2000, p. 121) concluded, "Of potential importance for conservation investment consideration, a comparison of each area with the land ownership layer in the Utah GAP (Edwards et al. 1995) indicated a large portion of both areas as privately owned."

Finally, fifteen statements were made in eleven publications that GAP data were used in studies of change. For example, McKerrow (2007, p. 85) stated, "Specifically, we wanted to use the newly available 2001 GAP Ecological Systems map for the Onslow Bight as a base and perform backcasting to identify the pattern and types of land cover changes that had occurred between 1992 and 2001."

\section{Critiques}

The statements that were categorized as critiques described limitations and problems with and cautions regarding the use of GAP data. There were 121 statements from 85 publications included in this category. The critiques addressed several different issues. Accuracy of GAP data and of products based on GAP data was one issue. Comments about accuracy of GAP data were part of 29 statements from 24 publications. For example, Lipow and others (2004, p. 422) stated, "The accuracy of the treedistribution maps was lowest in southwestern Oregon, where they were based on the relatively poorresolution Oregon GAP coverage." Peterson (2008) suggested that the accuracy issue warranted a particular interpretation. Peterson (2008, p. 33) wrote, "Accuracy assessment on REGAP data suggests 
that annual grass cover is generally underestimated for sites with high cover, thus the map should be interpreted as an index of cover rather than an estimate of actual cover."

Other authors addressed errors in GAP data. There were 26 comments about error from 21 publications. Some statements were quite general. McCarthy (1998, p. 57) stated, "Like most ecological models, Arizona GAP models are subject to error for numerous reasons." Alfieri and others (2007, p. 1804) stated, "... while the GAP dataset is more accurate than the NLCD 92 data set, it still contains significant errors." Wolter and others (2006, p. 613) made a more specific statement regarding error. They wrote, "The water class of the Michigan GAP classification available at the time of this project was found to include erroneous lowland conifer classes-specifically black spruce in Landsat path 22/row 28."

Limits in the use of GAP data were noted in some statements included in the critique category. Certain information lacking from GAP data was noted 22 times in 19 publications. Other limits were noted in 26 statements in 21 publications. Enquist and Gori (2008, p. 415) noted a lack of certain information in the classification of GAP data, and stated "The GAP vegetation system, a widelyemployed vegetation classification for Arizona and New Mexico, was also printed on the maps to serve as a general reference to vegetation type (Thompson et al. 1996; Halvorson et al. 2001). However, it should be noted that the developers of the GAP map did not incorporate information on the amount of shrub cover nor presence of non-native grasses as a means of classifying grassland association types." A limit related to classification was also commented on by Hurley (2001, p. 104), who wrote, "Oregon GAP neglects to separate out certain types of agriculture, namely orchards. *** Consequently, the current analysis identifies large chunks of agriculture within areas identified by ORGAP as native forest or woodlands. The large tracts of orchard evident from air photos do not appear in the Oregon GAP map." Larson and Sengupta (2004, p. 17) describe the limitation to the use of GAP data created by data quality issues. They state, "However, the effectiveness of the results generated by the SDSS [spatial decision support system] is currently limited by the quality of the GAP data available to perform such analyses." Thompson and others (2001, p. 240) cautioned others to careful use of GAP data when they stated, "Results of our research indicate estimates based on breeding areas do not reliably coincide with areas used by non-breeding birds. If the goal of the GAP is to broadly represent biodiversity, including migrant birds is essential. However, keeping migrant species distributions and richness estimates separate from breeding bird distributions and richness estimates (as currently recommended by GAP coordinators) is an acceptable way to present this information as long as it is recognized that breeding birds are probably not suitable surrogates for all birds when attempting to locate areas of significant use. *** we stress the importance of carefully framing the questions investigated with GAP data sets."

Finally, 18 critiques addressed the limits to the utility or usefulness of GAP data. These statements came from 15 publications. Peterson (2005, p. 232-233) wrote, "The difference seems to be a result of uneven methods in the Kansas Gap program for establishing likely presence of a particular species in a particular land use or land cover type, making for unstable predictions using the Gap method." Weathers and others (2009, p. 147-148) made this comment about the use of GAP data, "GAP land cover data were used as the primary source for habitat type. However, because of (1) availability of higher resolution data (i.e., DOQQ [digital orthophoto quarter quadrangles] imagery and DEMs [digital elevation models), (2) incorrect land classification resulting from the coarse resolution of the data, and (3) changes in land cover realized after the GAP baseline data were captured (in 1992), this data set was not solely relied on for habitat classification." 


\section{Comparisons}

As described in a previous section, some use of GAP data was for the purpose of comparing GAP data to other data. The statements included in the section on how data were used included statements describing the comparisons. We categorized statements regarding the outcomes of comparisons between GAP data and other data into a separate category. There were 51 statements from 34 publications describing how GAP data fared in comparison to other data.

Nineteen statements from 15 publications indicated that the result of the comparison was unfavorable to GAP. All of the 15 publications cited use of data from state GAP projects. Eleven of the 15 publications cited the use of land-cover data; three publications used predicted species distribution data; one publication used land cover and predicted species distribution data. Thorne and others (2004, p. 359) compared GAP data to the CalVeg map and to a map created by the authors based on the Manual of California Vegetation (MCV); they concluded that "Where equal vegetation type extents were measured between GAP and MCV, MCV provides more information about the distribution." Specifically, they stated, "In a comparison with two previous digital vegetation maps for the area, the US Forest Service's CalVeg and the Gap Analysis Program's GAP maps, the MCV map had finer spatial and floristic resolution. The MCV map has 15 more vegetation types than CalVeg and 22 more vegetation types than GAP. The MCV map contains more riparian corridors and isolated wetlands, identifying $157 \mathrm{~km}^{2}$ of these types, compared to $7 \mathrm{~km}^{2}$ for CalVeg and a non-spatial result for GAP." (Thorne and others, 2004, p. 343).

Fifteen statements from 11 publications indicated that the result of the comparison was favorable to GAP. The publications providing these favorable statements most frequently used land cover data from state GAP projects. Eight of the 11 publications used state project land cover data. State project predicted species distribution data, and regional project land cover and predicted species data were each cited in one publication that provided favorable statements regarding the comparison of GAP data to other data. Mehaffey and others (2009) compared GAP data to other data when deciding which dataset to use in their study of air pollution on habitat. They described their conclusion as, "We used final-draftbefore-release SE-GAP data. We believe the data is high quality and accurately maps potential habitat for the species groups we examined (SE-GAP 2007). *** Qualitative comparison of the SE-GAP data compared favorably, in respect to overall distribution of habitat, to other ecological model output for the region such as the Southeast Ecological Framework (USEPA 2002) and as such we felt it was adequate for the purpose of demonstrating the toxic vulnerability methods of this study." (Mehaffey and others, 2009, p.154).

Nine statements from seven publications described mixed results from a comparison of GAP data to other data. We classified statements as mixed if the authors described the results of the comparison as being favorable to GAP in some way and unfavorable to GAP in another way. For example, Peterson and Kluza (2003, p. 49, 51) wrote, "Omission error was lower in gap models (Table 1). In 24 of 30 species, gap models had better success in predicting the 20 test presence points, whereas GARP [Genetic Algorithm for Rule-Set Prediction] models were better in only three species; the two methods tied for three species. Hence, on the omission criterion, gap models performed better than GARP models. The situation regarding commission error, however, was different. For this error component, GARP models outperformed gap models in 28 of 30 species, with substantial differences in commission error (Table 1)." In another example, Wardlow and Egbert (2003, p. 1396) stated, "NLCD [National Land Cover Data] gives a useful first-order view of general land-cover patterns at the state to regional level and GAP provides a more detailed view of localized land-cover patterns within the state." Four of the seven publications that generated these mixed statements cited use of state project land cover data. State project predicted species distribution data and regional project land cover data were 
each cited in one of the seven publications. One publication used state project land cover and stewardship data.

Finally, eight statements from eight publications described GAP data as equivalent to other data. Five of these eight publications used state project land cover data. One publication used land cover and stewardship data from a state project; one publication used regional predicted species distribution data; and one publication used stewardship and predicted species distribution data from a regional project. Moen, Burdett, and Niemi (2008) used GAP data and compared it to another land-cover dataset. They concluded "The LULC [Land Use Land Cover] and GAP coverages were created from different LANDSAT scenes, were classified by different organizations, and had different cover type naming conventions (MDNR, 2007a, b, p. 1512). Yet both classifications resulted in similar relationships between selected cover types and distance from the den site."

\section{Commentary}

The theme we labeled as commentary includes statements that are favorable to GAP but that do not arise from a comparison of GAP data to other data. Thirty-nine statements from 32 publications were categorized as commentary. Twenty-six statements from 22 publications were strictly favorable to GAP. For example, Chung and Winer (1999, p. 195) stated, "Despite the discrepancies between predicted and observed plant species cover, on average the utility of the GAP database for developing BHC [biogenic hydrocarbons] emission inventories appears to be adequate." Clark and Slusher (2000, p. 77) described the importance of GAP stewardship data to their study. "Because areas managed by ILDNR [Illinois Department of Natural Resources], IDNR [Indiana Department of Natural Resources], TNC [The Nature Conservancy], NAWMP [North American Waterfowl Management Plan], counties, and the military were important in the analysis, the Gap Analysis Stewardship data layer proved essential to Phase 1."

Other comments indicated that a potential negative aspect of GAP was mitigated in their situation and was either not a problem or was favorable. Thirteen statements from 12 publications indicated that GAP issues were mitigated. Dumas (2005, p. 75-76) wrote, "Anyone with a working knowledge of ArcGISTM can easily work with the GAP datasets. It is standardized and nationally accepted, easy to use with standard GIS tools and free to the public. The only drawback experienced was the dating of the data. GAP data for this project was based on LandSat imagery from the mid-1990s and a lot can change in that amount of time, however because this project was based within the Bienville National Forest, most of the landcovers have not changed in that amount of time." Another example that indicated the datedness of GAP data was not an issue was found in Thatcher and others (2009, p. 919), who stated, "We chose a subset of the panther telemetry data for analysis that coincided with a time period within 5 years (1988-1998) of the Florida Gap Analysis Program (GAP) land-cover data (1993, see "Landscape data"). Although more recent landscape data were available, the majority of the radiotelemetry data coincided with the 1993 landscape data set." Not all of the statements were about the datedness of data. Comments in the critique category previously described in this report address accuracy of GAP data as a concern. McClain and Porter (2000, p. 558) described GAP accuracy as less of a concern. They wrote, "However, in both the HSI [habitat suitability index] and PATREC [pattern recognition] models, the data obtained from the GAP classification had higher correlations with the harvest data (highest GAP $\mathrm{r}^{2}=0.584$, highest NFLI [Northern Forest Lands Inventory] $\mathrm{r}^{2}=0.328$ ). The better predictability of the GAP data suggests that GAP's slightly lower accuracy is not as detrimental as NFLI's 10-ha mmu [minimum mapping unit]." 


\section{Reference to GAP Data}

The final theme included references to GAP data and products that were not specifically about use of GAP data. There were 81 statements from 67 publications in this category. Larson and Sengupta (2004, p. 11) made a descriptive statement about GAP data and wrote, "Most of the analysis was performed in raster mode, which is the native format of the GAP datasets released by the state agencies." Similarly, McCarthy (1998) described the products of Arizona GAP. McCarthy wrote, "Arizona's participation in GAP has resulted in a vegetation map with a greater resolution than previous editions and over 500 geo-referenced predicted vertebrate distribution maps" (p. 61).

\section{Summary}

One of the unique contributions of this publication search is that it provided a view of what statements were made and how GAP data were described in the public realm. Examination of the statements made in these publications illustrated how GAP data were depicted by those who have made use of these datasets. Authors identified GAP as their source of data and provide descriptions of varying detail regarding the datasets they used. The descriptions of how GAP data were used were also varied. Some of the statements described the tactical use of GAP data-how the data were used as a foundation for another analytical technique or to select study sites. Statements made in these publications also indicated that transformations to GAP data were necessary for some applications. These transformations could involve combining GAP with other data, excluding some data from the GAP datasets, or altering the format of the data. This suggests that a minimum level of expertise may be needed by those who use GAP data.

The statements regarding how GAP data were used suggested a range of applications. While some of the applications seem to fall in line with the goal of GAP, such as the studies of species, studies for prediction and planning, and identification of management and protection status, other publications indicated a use of GAP data for other purposes. The emergent category of change studies which primarily focused on landscape change demonstrates that GAP data have been used to study issues of increasing importance that may not be directly related to conservation of biodiversity.

The evaluative comments that were made regarding GAP data that were included in the critique, comparisons, and commentary themes present a mixed picture of GAP data. The issues raised in some publications as critiques of GAP data such as accuracy, errors, and limits based on characteristics of the data, were described in other publications as issues that did not impact the study or were otherwise mitigated. Comparisons of GAP data to other datasets yielded results that were unfavorable, favorable, and mixed towards GAP. The diversity of these comments suggests that issues with GAP data may be application specific. In other words, an issue in one study may be a nonissue in another. For example, the datedness of the state GAP datasets may create an accuracy issue in one study dependent on the goal of that study. However, the datedness may be a nonissue if there has not been much change in the characteristic mapped by the GAP dataset (such as land cover) or may actually be a benefit such as in studies of changes in landscape characteristics. For all categories of comparison outcome, the most frequently used datasets in those publications were land cover data from state GAP projects. This may reflect the overall higher levels of use of land cover data from state projects in the set of publications we identified.

These themes provided us with information to use in developing topics to include on the survey. In particular, the survey will include questions addressing the issues raised in the how data were used, critiques, commentary, and comparisons themes. Specifically the survey will include questions regarding the issues of accuracy, error, to what extent issues of accuracy and error are problematic to the user, what GAP data lack that would be useful, what transformations are necessary to make GAP data 
useful, and how GAP data compare to other datasets. The survey will also include questions regarding the level of GIS expertise needed to make use of GAP data.

\section{Bibliometric Analysis}

Bibliometric methods include a set of techniques for the quantitative study of publications (Gauthier, 1998; Schubert and others, 1988; Wallin, 2005). The results of bibliometric analyses have been used as components in the performance evaluation process for research programs (Campbell and others, 2010; Frame, 1983; Gauthier, 1998; Kostoff, 1995; Leydesdorff, 2005; Narin, 1987; Trochim and others, 2008; Verbeek and others, 2002) and in science policy and planning (Irvine and others, 1987). Bibliometric analyses are not recommended as stand alone methods for evaluation but are considered a useful component to use in conjunction with other methods (Melkers, 1993; Pendlebury, 2009).

The most commonly used measures in bibliometric analyses for evaluation (Martin, 1996; Narin and others, 1994) are publication and citation counts. These can be used as partial indicators of research impact (Campbell and others, 2010; Frame, 1983; Martin and Irvine, 1983; Mullins, 1987; Schubert and others, 1988). Number of publications is considered an acceptable measure of research production (Martin, 1996; Melkers, 1993; Narin and Hamilton, 1996; Shapira and others, 2003; van Raan, 1989; Verbeek and others, 2002) or research activity (Kostoff, 1995; Narin, 1987). A count of the number of publications has been used to evaluate the impact of a program providing resources to researchers (Campbell and others, 2010). For example, Campbell and others (2010) evaluated the effect of a program that provides funding to researchers. GAP is in a similar position in that it provides resources in the form of datasets. Bibliometric techniques have been used in program evaluation for federal agencies (U.S. Environmental Protection Agency, 2006; Kostoff, 1994; Kostoff, 1995; Porter and others, 2003; Porter and others, 2010; Roessner, 2002; Trochim and others, 2008). These techniques have been recommended as useful in documentation for the Government Performance and Results Act to demonstrate the results of a program (Hicks and others, 2004; Narin and Hamilton, 1996).

In the case of GAP, the results of a bibliometric analysis are an indirect evaluation of the program because GAP itself did not produce the publications in the analysis. GAP produced the datasets which were used by the authors who wrote the publications. There may have been uses of GAP data to create maps or documents that have not been published because they were used exclusively for management of natural areas. The bibliometric analysis indicated the research impact of GAP_an added benefit given that the primary objective of GAP is to promote management of land for the conservation of biodiversity. Previous evaluations of databases - instead of programs - have included bibliometric analyses (Hicks and others, 2004). Bibliometric analyses have been used to investigate the use of publications in diffusion of innovation (Genuis, 2005) and evaluation of research and development activities (Melkers, 1993). In a sense, the datasets produced by GAP are an innovation and identifying how they have been used to generate publications provides evidence regarding the level of diffusion achieved.

Based on prior use of bibliometric analysis for programs and databases and for federal programs, we concluded that this analysis was appropriate to include in the evaluation of published literature citing GAP data.

The weakness of any given indicator in bibliometric analysis can be offset by combining it with other measures (Thelwall, 2004). In the bibliometric analysis for literature citing datasets produced by GAP, we used descriptive indicators including journal impact factors, journal impact ranks, and citations. These indicators are considered evidence of the volume of scientific output related to a 
program and the impact of program output on the development of knowledge in a field (Campbell and others, 2010; Gauthier, 1998).

\section{Publication Count}

The set of 646 nonduplicate publications collected for the literature review was included in the bibliometric analysis. The publication dates ranged from 1994 to 2011 . Fifty-three percent of the publications were journal articles. We summarize the journal impact factors and ranks for the journal publications only. We included all 646 publications in our search for citations.

\section{Journal Impact}

The journal impact factor represents the frequency of citation for an average article from a journal within a defined time period (Garfield, 1994). Although the journal impact factor is not a perfect measure of the research impact of any article published in the journal, the impact factor of the journal is often used as a proxy measure of impact of the articles included in the journal (Davis and Royle, 1996; Seglen, 1997). The journal impact factor has been demonstrated to relate to the perceived prestige of the journal (Davis and Royle, 1996). Some of the specific criticisms of use of the journal impact factor, for example that many databases are less likely to index non-U.S. publications (Rey-Rocha and others, 2001; Seglen, 1997; Verbeek and others, 2002), are not relevant to our bibliometric analysis for publications citing GAP data. The databases produced by GAP are specific to the U.S. and publications using GAP data are likely to be published in U.S.-based journals. However, our set of publications also includes journal articles published in European-based journals. We found that some of these journals are indexed in the databases we used for the bibliometric analysis making less relevant the criticism that non-U.S. publications are less likely to be indexed.

We obtained five-year journal impact factors and ranks from the Web of Science Journal Citations Report ${ }^{\circledR}$ (JCR) Science Edition 2010. These were the current journal impact factors and in some cases may differ from the journal impact factor at the publication date of individual articles. Journal impact factors do not generalize across disciplines (Gauthier, 1998; Narin and Hamilton, 1996; Seglen, 1997) and so caution must be exercised in interpreting the results for multiple disciplines. Journal ranks indicate the relative standing of a journal based on its impact factor compared to other journals within the same discipline. We report the number of articles from each journal appearing in the list of publications citing GAP data, with the impact factor, the discipline with which the journal is affiliated, the journal impact rank, and the corresponding quartile of the rank in table 2 .

Table 2. Number of articles appearing in each journal, 2010 journal impact factor, discipline, and journal impact rank.

\begin{tabular}{lcclcc}
\hline \multicolumn{1}{c}{ Journal Title } & $\begin{array}{c}\text { Number } \\
\text { of } \\
\text { Articles }\end{array}$ & $\begin{array}{c}\mathbf{5} \mathbf{y r} \\
\text { Journal } \\
\text { Impact }\end{array}$ & Category & $\begin{array}{c}\text { Journal } \\
\text { Rank }\end{array}$ & Quartile \\
\hline Journal of Wildlife Management & 20 & 1.977 & Ecology & $73 / 129$ & Q3 \\
\hline Conservation Biology & 17 & 5.963 & Biodiversity Conservation & $2 / 33$ & Q1 \\
\hline Ecological Applications & 14 & 5.067 & Ecology & $23 / 129$ & Q1 \\
\hline Landscape Ecology & 9 & 3.648 & Ecology & $35 / 129$ & Q2 \\
\hline
\end{tabular}


Table 2. Number of articles appearing in each journal, 2010 journal impact factor, discipline, and journal impact rank.-Continued

\begin{tabular}{|c|c|c|c|c|c|}
\hline Journal Title & $\begin{array}{l}\text { Number } \\
\text { of } \\
\text { Articles }\end{array}$ & $\begin{array}{c}5 \mathrm{yr} \\
\text { Journal } \\
\text { Impact }\end{array}$ & Category & $\begin{array}{l}\text { Journal } \\
\text { Rank }\end{array}$ & Quartile \\
\hline $\begin{array}{l}\text { Photogrammetric Engineering \& } \\
\text { Remote Sensing }\end{array}$ & 9 & 1.566 & $\begin{array}{l}\text { Imaging Science \& Photographic } \\
\text { Technology }\end{array}$ & $9 / 19$ & Q2 \\
\hline Wildlife Society Bulletin & 8 & $\mathrm{~N} / \mathrm{A}$ & & & \\
\hline Biological Conservation & 7 & 4.042 & Biodiversity Conservation & $6 / 33$ & Q1 \\
\hline $\begin{array}{l}\text { Environmental Monitoring and } \\
\text { Assessment }\end{array}$ & 6 & 1.539 & Environmental Sciences & $106 / 192$ & Q3 \\
\hline Natural Areas Journal & 6 & 0.863 & Ecology & $109 / 129$ & Q4 \\
\hline Environmental Management & 5 & 1.895 & Environmental Sciences & $101 / 192$ & Q3 \\
\hline Journal of Mammalogy & 5 & 2.074 & Zoology & $43 / 145$ & Q2 \\
\hline $\begin{array}{l}\text { Madroño: California Botanical } \\
\text { Society }\end{array}$ & 5 & N/A & & & \\
\hline Molecular Ecology & 5 & 6.633 & Ecology & $5 / 129$ & Q1 \\
\hline Remote Sensing of Environment & 5 & 4.605 & Environmental Sciences & $16 / 192$ & Q1 \\
\hline Southwestern Naturalist & 5 & 0.547 & Ecology & $120 / 129$ & Q4 \\
\hline Monthly Weather Review & 4 & 2.649 & $\begin{array}{l}\text { Meteorology \& Atmospheric } \\
\text { Sciences }\end{array}$ & $18 / 68$ & Q2 \\
\hline $\begin{array}{l}\text { American Journal of Tropical } \\
\text { Medicine and Hygiene }\end{array}$ & 3 & 2.884 & $\begin{array}{l}\text { Public, Environmental, \& } \\
\text { Occupational Health }\end{array}$ & $38 / 140$ & Q2 \\
\hline American Midland Naturalist & 3 & 0.768 & Ecology & $115 / 129$ & Q4 \\
\hline Animal Conservation & 3 & 3.037 & Ecology & $42 / 129$ & Q2 \\
\hline Auk & 3 & 2.276 & Ornithology & $3 / 19$ & Q1 \\
\hline Diversity and Distributions & 3 & 4.550 & Ecology & $25 / 129$ & Q1 \\
\hline Ecography & 3 & 5.325 & Ecology & $22 / 129$ & Q1 \\
\hline Environmental Modelling \& Software & 3 & 2.900 & Environmental Sciences & $38 / 192$ & Q1 \\
\hline Forest Ecology and Management & 3 & 2.507 & Forestry & $6 / 54$ & Q1 \\
\hline $\begin{array}{l}\text { International Journal of Remote } \\
\text { Sensing }\end{array}$ & 3 & 1.551 & Remote Sensing & $9 / 23$ & Q2 \\
\hline Journal of Arid Environments & 3 & 2.064 & Environmental Sciences & $99 / 192$ & Q3 \\
\hline Journal of Forestry & 3 & 1.465 & Forestry & $23 / 54$ & Q2 \\
\hline Journal of Medical Entomology & 3 & 2.257 & Veterinary Sciences & $17 / 145$ & Q1 \\
\hline $\begin{array}{l}\text { Journal of the American Water } \\
\text { Resources Association }\end{array}$ & 3 & 1.771 & Geosciences, Multidisciplinary & $77 / 165$ & Q2 \\
\hline Landscape and Urban Planning & 3 & 2.789 & Ecology & $57 / 129$ & Q2 \\
\hline $\begin{array}{l}\text { North American Journal of Fisheries } \\
\text { Management }\end{array}$ & 3 & 1.439 & Fisheries & $20 / 46$ & Q2 \\
\hline Southeastern Naturalist & 3 & 0.501 & Ecology & $125 / 129$ & Q4 \\
\hline Wetlands & 3 & 1.810 & Environmental Sciences & $119 / 192$ & Q3 \\
\hline
\end{tabular}


Table 2. Number of articles appearing in each journal, 2010 journal impact factor, discipline, and journal impact rank.-Continued

\begin{tabular}{|c|c|c|c|c|c|}
\hline Journal Title & $\begin{array}{c}\text { Number } \\
\text { of } \\
\text { Articles }\end{array}$ & $\begin{array}{c}5 \mathrm{yr} \\
\text { Journal } \\
\text { Impact }\end{array}$ & Category & $\begin{array}{l}\text { Journal } \\
\text { Rank }\end{array}$ & Quartile \\
\hline $\begin{array}{l}\text { American Fisheries Society } \\
\text { Symposium }\end{array}$ & 2 & N/A & & & \\
\hline Applied Geography* & 2 & 2.320 & Geography & $10 / 65$ & Q1 \\
\hline Atmospheric Environment & 2 & 3.435 & Environmental Sciences & $24 / 192$ & Q1 \\
\hline Biodiversity and Conservation & 2 & 2.336 & Biodiversity Conservation & $12 / 33$ & Q2 \\
\hline Condor & 2 & 1.775 & Ornithology & $5 / 19$ & Q2 \\
\hline Ecohydrology & 2 & 1.873 & Ecology & $63 / 129$ & Q2 \\
\hline Ecological Indicators & 2 & 3.058 & Environmental Sciences & $36 / 192$ & Q1 \\
\hline Ecological Modelling & 2 & 2.438 & Ecology & $68 / 129$ & Q3 \\
\hline Ecology and Society & 2 & 4.644 & Ecology & $34 / 129$ & Q2 \\
\hline Ecosystems & 2 & 4.735 & Ecology & $26 / 129$ & Q1 \\
\hline Emerging Infectious Diseases & 2 & 6.996 & Immunology & $14 / 134$ & Q1 \\
\hline Forest Policy and Economics & 2 & 1.315 & Forestry & $25 / 54$ & Q2 \\
\hline Forest Science & 2 & 1.590 & Forestry & $18 / 54$ & Q2 \\
\hline Global Change Biology & 2 & 7.814 & Ecology & $6 / 129$ & Q1 \\
\hline Global Ecology and Biogeography & 2 & 6.330 & Ecology & $10 / 129$ & Q1 \\
\hline Journal of Coastal Research & 2 & 0.690 & Environmental Sciences & $168 / 192$ & Q4 \\
\hline $\begin{array}{l}\text { Journal of Soil and Water } \\
\text { Conservation }\end{array}$ & 2 & 1.695 & Water Resources & $27 / 76$ & Q2 \\
\hline $\begin{array}{l}\text { Journal of the Arkansas Academy of } \\
\text { Science }\end{array}$ & 2 & $\mathrm{~N} / \mathrm{A}$ & & & \\
\hline Journal of Vegetation Science & 2 & 3.002 & Forestry & $2 / 54$ & Q1 \\
\hline $\begin{array}{l}\text { Occasional papers, Museum of Texas } \\
\text { Tech University }\end{array}$ & 2 & $\mathrm{~N} / \mathrm{A}$ & & & \\
\hline Oikos & 2 & 3.920 & Ecology & $33 / 129$ & Q2 \\
\hline PloS ONE & 2 & 4.610 & Biology & $12 / 85$ & Q1 \\
\hline Professional Geographer* & 2 & 1.988 & Geography & $18 / 65$ & Q2 \\
\hline Quaternary Research & 2 & 3.310 & Geosciences, Multidisciplinary & $28 / 165$ & Q1 \\
\hline $\begin{array}{l}\text { Soil Science Society of America } \\
\text { Journal }\end{array}$ & 2 & 2.598 & Soil Science & $13 / 32$ & Q2 \\
\hline Southern Journal of Applied Forestry & 2 & 0.713 & Forestry & $40 / 54$ & Q3 \\
\hline Studies in Avian Biology & 2 & $\mathrm{~N} / \mathrm{A}$ & & & \\
\hline $\begin{array}{l}\text { Transactions of the Kansas Academy } \\
\text { of Science }\end{array}$ & 2 & $\mathrm{~N} / \mathrm{A}$ & & & \\
\hline Ursus & 2 & 1.090 & Zoology & $95 / 145$ & Q3 \\
\hline Western Journal of Applied Forestry & 2 & 0.660 & Forestry & $37 / 54$ & Q3 \\
\hline Wildlife Biology & 2 & 1.137 & Zoology & $96 / 145$ & Q3 \\
\hline Wilson Journal of Ornithology & 2 & 0.593 & Ornithology & $15 / 19$ & Q4 \\
\hline
\end{tabular}


Table 2. Number of articles appearing in each journal, 2010 journal impact factor, discipline, and journal impact rank.-Continued

\begin{tabular}{|c|c|c|c|c|c|}
\hline Journal Title & $\begin{array}{c}\text { Number } \\
\text { of } \\
\text { Articles }\end{array}$ & $\begin{array}{c}5 \text { yr } \\
\text { Journal } \\
\text { Impact }\end{array}$ & Category & $\begin{array}{l}\text { Journal } \\
\text { Rank }\end{array}$ & Quartile \\
\hline Agricultural Water Management & 1 & 2.391 & Water Resources & $17 / 76$ & Q1 \\
\hline Ambio & 1 & 2.847 & Environmental Sciences & $86 / 192$ & Q2 \\
\hline $\begin{array}{l}\text { American Journal of Enology and } \\
\text { Viticulture }\end{array}$ & 1 & 2.568 & Horticulture & $6 / 30$ & Q1 \\
\hline $\begin{array}{l}\text { Annals of the Association of } \\
\text { American Geographers* }\end{array}$ & 1 & 2.986 & Geography & $11 / 65$ & Q1 \\
\hline Applied Vegetation Science & 1 & 2.091 & Forestry & $9 / 54$ & Q1 \\
\hline Biological Invasions & 1 & 3.749 & Biodiversity Conservation & $7 / 33$ & Q1 \\
\hline Bioresource Technology & 1 & 4.901 & Energy \& Fuels & $9 / 78$ & Q1 \\
\hline BioScience & 1 & 6.335 & Biology & $7 / 85$ & Q1 \\
\hline Bryologist & 1 & 1.039 & Plant Sciences & $108 / 187$ & Q3 \\
\hline California Agriculture** & 1 & 0.918 & Agriculture, Multidisciplinary & $15 / 55$ & Q2 \\
\hline $\begin{array}{l}\text { Canadian Journal of Fisheries and } \\
\text { Aquatic Sciences }\end{array}$ & 1 & 2.690 & Fisheries & $6 / 46$ & Q1 \\
\hline Climatic Change & 1 & 4.433 & Environmental Sciences & $35 / 192$ & Q1 \\
\hline $\begin{array}{l}\text { Computing in Science and } \\
\text { Engineering }\end{array}$ & 1 & 0.899 & $\begin{array}{l}\text { Computer Science, Interdisciplinary } \\
\text { Applications }\end{array}$ & $66 / 97$ & Q3 \\
\hline Conservation and Society & 1 & $\mathrm{~N} / \mathrm{A}$ & & & \\
\hline Conservation Genetics & 1 & 1.889 & Biodiversity Conservation & $16 / 33$ & Q2 \\
\hline Digital Soil Mapping & 1 & $\mathrm{~N} / \mathrm{A}$ & & & \\
\hline Ecological Monographs & 1 & 8.827 & Ecology & $8 / 129$ & Q1 \\
\hline Ecological Research & 1 & 1.671 & Ecology & $89 / 129$ & Q3 \\
\hline Ecology & 1 & 6.218 & Ecology & $12 / 129$ & Q1 \\
\hline Ecology Letters & 1 & 14.261 & Ecology & $1 / 129$ & Q1 \\
\hline Endangered Species Update & 1 & N/A & & & \\
\hline Energy Policy & 1 & 3.020 & Environmental Sciences & $46 / 192$ & Q1 \\
\hline Environmental Entomology & 1 & 1.702 & Entomology & $21 / 83$ & Q2 \\
\hline Environmental Geology & 1 & 1.344 & Environmental Sciences & $135 / 192$ & Q3 \\
\hline $\begin{array}{l}\text { Environmental Science and Pollution } \\
\text { Research }\end{array}$ & 1 & 2.733 & Environmental Sciences & $39 / 192$ & Q1 \\
\hline Environmetrics & 1 & 0.986 & Statistics \& Probability & $64 / 110$ & Q3 \\
\hline Evolution & 1 & 6.041 & Ecology & $9 / 129$ & Q1 \\
\hline Fire Ecology & 1 & N/A & & & \\
\hline Forestry Chronicle & 1 & 0.845 & Forestry & $34 / 54$ & Q3 \\
\hline Freshwater Biology & 1 & 3.785 & Marine \& Freshwater Biology & $7 / 92$ & Q1 \\
\hline $\begin{array}{l}\text { Frontiers in Ecology and the } \\
\text { Environment }\end{array}$ & 1 & 7.931 & Environmental Sciences & $2 / 192$ & Q1 \\
\hline Geoderma & 1 & 2.806 & Soil Science & $5 / 32$ & Q1 \\
\hline
\end{tabular}


Table 2. Number of articles appearing in each journal, 2010 journal impact factor, discipline, and journal impact rank.-Continued

\begin{tabular}{|c|c|c|c|c|c|}
\hline Journal Title & $\begin{array}{l}\text { Number } \\
\text { of } \\
\text { Articles }\end{array}$ & $\begin{array}{l}5 \mathrm{yr} \\
\text { Journal } \\
\text { Impact }\end{array}$ & Category & $\begin{array}{l}\text { Journal } \\
\text { Rank }\end{array}$ & Quartile \\
\hline Geographical Review & 1 & 0.648 & Geography & $50 / 65$ & Q4 \\
\hline $\begin{array}{l}\text { Geoscience and Remote Sensing } \\
\text { Symposium Proceedings }\end{array}$ & 1 & N/A & & & \\
\hline Geospatial Health** & 1 & 1.705 & $\begin{array}{l}\text { Public, Environmental, \& } \\
\text { Occupational Health }\end{array}$ & $64 / 140$ & Q2 \\
\hline GIScience and Remote Sensing & 1 & N/A & & & \\
\hline Great Basin Naturalist & 1 & N/A & & & \\
\hline Great Plains Research & 1 & N/A & & & \\
\hline $\begin{array}{l}\text { Human and Ecological Risk } \\
\text { Assessment }\end{array}$ & 1 & 1.382 & Environmental Sciences & $103 / 192$ & Q3 \\
\hline Human Dimensions of Wildlife & 1 & N/A & & & \\
\hline Human Ecology Review** & 1 & 1.000 & Sociology & $43 / 129$ & Q2 \\
\hline Hydrobiologia & 1 & 1.997 & Marine \& Freshwater Biology & $25 / 92$ & Q2 \\
\hline Hydrological Sciences Journal & 1 & 1.891 & Water Resources & $26 / 76$ & Q2 \\
\hline Insecta Mundi & 1 & N/A & & & \\
\hline $\begin{array}{l}\text { Integrated Environmental Assessment } \\
\text { and Management }\end{array}$ & 1 & N/A & & & \\
\hline $\begin{array}{l}\text { International Journal of Biodiversity } \\
\text { and Conservation }\end{array}$ & 1 & N/A & & & \\
\hline International Journal of Wildland Fire & 1 & 2.523 & Forestry & $5 / 54$ & Q1 \\
\hline $\begin{array}{l}\text { Invasive Plant Science and } \\
\text { Management }\end{array}$ & 1 & N/A & & & \\
\hline IUCN Otter Specialist Group Bulletin & 1 & N/A & & & \\
\hline Journal of Applied Ecology & 1 & 5.715 & Ecology & $14 / 129$ & Q1 \\
\hline Journal of Applied Remote Sensing** & 1 & 1.000 & Remote Sensing & $11 / 23$ & Q2 \\
\hline Journal of Biogeography & 1 & 4.716 & Ecology & $24 / 129$ & Q1 \\
\hline Journal of Conservation Planning & 1 & N/A & & & \\
\hline Journal of Environmental Engineering & 1 & 1.217 & Engineering, Civil & $31 / 115$ & Q2 \\
\hline $\begin{array}{l}\text { Journal of Environmental Planning } \\
\text { and Management** }\end{array}$ & 1 & 1.111 & Environmental Studies & $39 / 77$ & Q3 \\
\hline Journal of Environmental Quality & 1 & 2.738 & Environmental Sciences & $56 / 192$ & Q2 \\
\hline Journal of Great Lakes Research & 1 & 1.789 & Environmental Sciences & $115 / 192$ & Q3 \\
\hline Journal of Insect Conservation & 1 & 1.901 & Entomology & $17 / 83$ & Q1 \\
\hline Journal of Land Use Science & 1 & N/A & & & \\
\hline Journal of Raptor Research & 1 & 0.568 & Ornithology & $16 / 19$ & Q4 \\
\hline Journal of Remote Sensing & 1 & N/A & & & \\
\hline
\end{tabular}


Table 2. Number of articles appearing in each journal, 2010 journal impact factor, discipline, and journal impact rank.-Continued

\begin{tabular}{|c|c|c|c|c|c|}
\hline Journal Title & $\begin{array}{l}\text { Number } \\
\text { of } \\
\text { Articles }\end{array}$ & $\begin{array}{l}5 \mathrm{yr} \\
\text { Journal } \\
\text { Impact }\end{array}$ & Category & $\begin{array}{l}\text { Journal } \\
\text { Rank }\end{array}$ & Quartile \\
\hline $\begin{array}{l}\text { Journal of the North American } \\
\text { Benthological Society }\end{array}$ & 1 & 3.920 & Marine \& Freshwater Biology & $9 / 92$ & Q1 \\
\hline $\begin{array}{l}\text { Journal of the Torrey Botanical } \\
\text { Society }\end{array}$ & 1 & 1.114 & Plant Sciences & $128 / 187$ & Q3 \\
\hline $\begin{array}{l}\text { Journal of Water Resources Planning } \\
\text { and Management }\end{array}$ & 1 & 1.993 & Engineering, Civil & $25 / 115$ & Q1 \\
\hline Kalmiopsis & 1 & N/A & & & \\
\hline Lake and Reservoir Management & 1 & 0.742 & Marine \& Freshwater Biology & $75 / 92$ & Q4 \\
\hline Marine Geodesy** & 1 & 0.917 & Oceanography & $39 / 59$ & Q3 \\
\hline Marine Pollution Bulletin & 1 & 2.899 & Marine \& Freshwater Biology & $15 / 92$ & Q1 \\
\hline McNair Research Journal & 1 & $\mathrm{~N} / \mathrm{A}$ & & & \\
\hline Northeastern Naturalist & 1 & 0.567 & Biodiversity Conservation & $23 / 33$ & Q3 \\
\hline Northern Journal of Applied Forestry & 1 & 0.741 & Forestry & $35 / 54$ & Q3 \\
\hline Northwest Science & 1 & 0.531 & Ecology & $124 / 129$ & Q4 \\
\hline Northwestern Naturalist & 1 & N/A & & & \\
\hline Ocean Engineering & 1 & 1.038 & Engineering, Civil & $38 / 115$ & Q2 \\
\hline Oecologica & 1 & N/A & & & \\
\hline Parks & 1 & N/A & & & \\
\hline Peromyscus Newsletter & 1 & $\mathrm{~N} / \mathrm{A}$ & & & \\
\hline Physics and Chemistry of the Earth & 1 & 1.211 & Water Resources & $44 / 76$ & Q3 \\
\hline $\begin{array}{l}\text { Proceedings of the National Academy } \\
\text { of Sciences }\end{array}$ & 1 & 10.591 & Multidisciplinary Sciences & $3 / 57$ & Q1 \\
\hline Pure and Applied Geophysics & 1 & 1.231 & Geochemistry \& Geophysics & $46 / 77$ & Q3 \\
\hline Rangeland Ecology \& Management & 1 & 1.579 & Ecology & $82 / 129$ & Q3 \\
\hline Sensors & 1 & 1.917 & Instruments \& Instrumentation & $14 / 61$ & Q1 \\
\hline Transactions in GIS & 1 & $\mathrm{~N} / \mathrm{A}$ & & & \\
\hline $\begin{array}{l}\text { Transactions of the American } \\
\text { Entomological Society }\end{array}$ & 1 & 0.414 & Entomology & $74 / 83$ & Q4 \\
\hline $\begin{array}{l}\text { Transactions of the American } \\
\text { Fisheries Society }\end{array}$ & 1 & 1.959 & Fisheries & $13 / 46$ & Q2 \\
\hline Transactions of the ASABE & 1 & 1.193 & Agricultural Engineering & $8 / 12$ & Q3 \\
\hline Urban Ecosystems & 1 & N/A & & & \\
\hline Water Resources Research & 1 & 3.081 & Water Resources & $2 / 76$ & Q1 \\
\hline Water, Air, and Soil Pollution & 1 & 1.929 & Water Resources & $19 / 76$ & Q2 \\
\hline Waterbirds & 1 & 0.746 & Ornithology & $14 / 19$ & Q3 \\
\hline Weather and Forecasting & 1 & 1.980 & $\begin{array}{l}\text { Meteorology \& Atmospheric } \\
\text { Sciences }\end{array}$ & $38 / 68$ & Q3 \\
\hline Western North American Naturalist & 1 & 0.454 & Ecology & $121 / 129$ & Q4 \\
\hline
\end{tabular}


Table 2. Number of articles appearing in each journal, 2010 journal impact factor, discipline, and journal impact rank.-Continued

\begin{tabular}{|c|c|c|c|c|c|}
\hline Journal Title & $\begin{array}{c}\text { Number } \\
\text { of } \\
\text { Articles }\end{array}$ & $\begin{array}{c}\mathrm{yr} \\
\text { Journal } \\
\text { limpact }\end{array}$ & Category & $\begin{array}{c}\text { Journal } \\
\text { Rank }\end{array}$ & Quartile \\
\hline Wildfowl & 1 & $\mathrm{~N} / \mathrm{A}$ & & & \\
\hline Wildlife Biology in Practice & 1 & N/A & & & \\
\hline Wyoming Open Spaces Bulletin & 1 & N/A & & & \\
\hline $\begin{array}{l}\text { Yearbook of the Association of } \\
\text { Pacific Coast Geographers }\end{array}$ & 1 & $\mathrm{~N} / \mathrm{A}$ & & & \\
\hline
\end{tabular}

*This journal did not appear in JCR Science Edition; the journal was included in JCR Social Science Edition 2010.

**No five-year Journal Impact Factor was available, the one-year Journal Impact Factor is substituted in this table. N/A indicates the journal was not listed in either edition of the Journal Citation Report.

The impact factor of the journals in which articles citing GAP data were published ranged from 14.261 (Ecology Letters) to 0.414 (Transactions of the American Entomological Society). The journals were affiliated with 34 disciplines. There were 101 articles citing GAP data published in journals affiliated with the Ecology discipline that were ranked at all four quartile levels. Journals affiliated with the Environmental Sciences discipline included 40 articles citing GAP data. The Environmental Sciences journals that cited GAP data included some journals from each quartile level. In the discipline of Biodiversity Conservation, 29 articles published appeared in journals ranked at the top three quartile levels. There were 20 articles citing GAP data published in journals affiliated with the Forestry discipline that were ranked in the top three quartiles. These are the results for the four disciplines with the largest numbers of articles within the set of publications citing GAP data. It is apparent that articles citing GAP data are published in multiple disciplines in journals of varying degrees of impact as defined by the journal impact factor.

The total number of articles and relative percent published in journals in each quartile within their respective disciplines is depicted in figure 8. This is based on the 289 publications for which this information was available. The purpose of this figure is to summarize to what extent GAP data appeared in publications at each level of relative prestige and impact based on quartile ranking. 


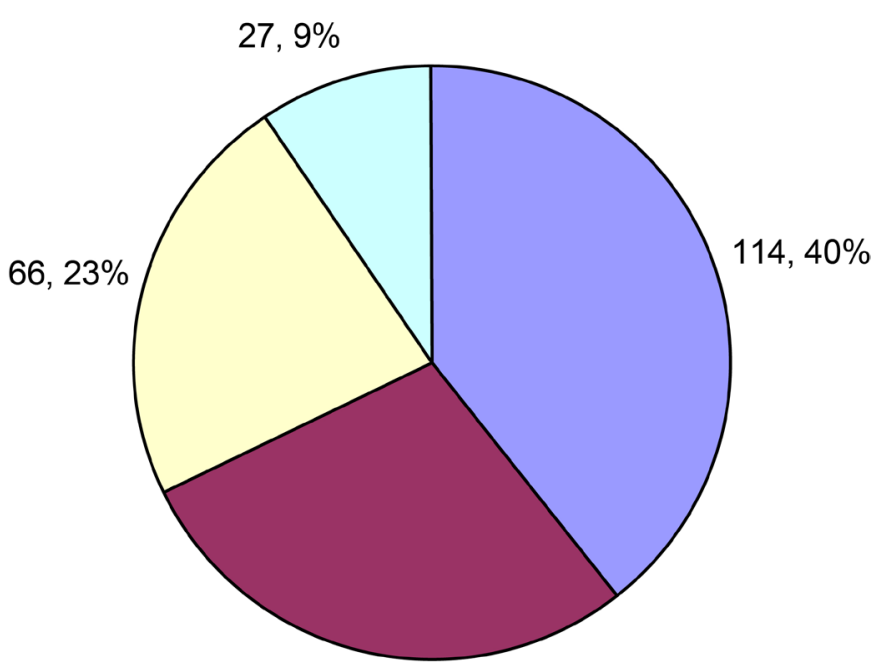

$82,28 \%$

$\square$ Q1 $\square$ Q2 $\square$ Q3 $\square$ Q4

Figure 8. Number and percent of articles published in journals at each quartile rank.

Forty percent of journal articles citing GAP data were published in quartile 1 (Q1) level journals. These are journals that are considered top level journals within their respective disciplines. Twentyeight percent of the articles were published in quartile 2 (Q2) level journals. A slightly smaller proportion, 23 percent, of articles citing GAP data were published in quartile 3 level journals. In reviewing the quartile rank information provided previously in table 2, many of the journals that appear at the third and fourth quartiles of their respective disciplines are regional in nature. For example, Q3 level journals include Northeastern Naturalist and the Southern Journal of Applied Forestry. These are journals that are likely to be circulated and cited less frequently than journals that have broader appeal such as Landscape Ecology, a Q1 level journal.

The actual citation counts should be considered when interpreting the journal impact factor (Wallin, 2005). Because of issues affecting calculation of journal impact factors, such as the limited time frame represented, the number of citations to a paper may be a better indicator of the impact of the paper than the journal impact factor (Fava and Ottolini, 2000; Retzer and Jurasinski, 2009).

\section{Citation Count}

Citation analysis indicates what is being cited and by whom (Melkers, 1993). Within the context of the larger program analysis of GAP, publication counts and citation analysis provided information about the use and impact of GAP data. Citation counts for an article can vary from year to year. Because of this phenomenon, the recommendation when using citation counts in bibliometric analyses is that the time period over which counts are taken should not be too limited (Verbeek and others, 2002). Citations are an imperfect but useful measure of research impact (Kostoff, 1995; Narin and Hamilton, 1996; Narin and others, 1994; Okubo, 1997; Porter and others, 2003; Verbeek and others 2002) and visibility in the research community (Frame, 1983). Citation data should not be interpreted as a measure of research quality (Seglen, 1997). Even though citations counts are considered imperfect, they are a conventional measure used to measure impact (Herbstein, 1993; Shapira and others, 2003). 
Research has demonstrated a correlation between citation data and other measures of influence or impact such as peer reviews (Garfield and Welljams-Dorof, 1992). The concerns about citation data tend to be reduced at higher levels of aggregation (Garfield and Welljams-Dorof, 1992, Okubo, 1997; Schubert and others, 1988). In this case we aggregated data at the program level for GAP and we did not evaluate publications at the level of individual authors. Bornmann and Daniel (2008) concluded in their review of studies of citation behavior that citations are a multidimensional measure. In part, citations do measure the impact of a paper and therefore can be used as a partial measure of research impact (Bornmann and Daniel, 2008).

Because of what is commonly known as the "time lag" in publications - the time it takes to write, revise, and publish an article-bibliometric analyses are appropriate for publications at least 2-3 years old (Herbstein, 1993) but not for very recent ones. When citation analyses are included in a bibliometric approach, as they are here, the time lag required is even longer (Frame, 1983). The article must be published and available for long enough for others to see it, cite it and then have their article published. In many circumstances this phenomenon would be considered a drawback. However, in program evaluation the effects of interest often do not occur until years after research is conducted or a program begins (Garfield and Welljams-Dorof, 1992; Kostoff, 1995). In this respect, bibliometric analyses fit well with the objectives of program evaluation. In the case of GAP, the time lag in publications means that many of the publications included in the literature review and bibliometric analyses cited the use of the state rather than regional datasets. However, when evaluating the impact of a scientist, a paper, or a program, more relevant information is provided by citation frequencies than by journal impact factors (Garfield, 2001). The citation frequencies reflect the impact over the life of an article whereas impact factors are based on a time limited (two or five year) average for the journal in which an article appears (Fava and Ottolini, 2000). Therefore, we used citation frequencies as part of our bibliometric analysis even though we knew that this approach would be less accurate for the more recent regional and national datasets.

We searched Web of Science to obtain citation lists. At the time of our citation search, the citation database had been updated on August 10, 2011. When conducting citation searches in Web of Science we used author name and year as search terms. One of the drawbacks to using a database such as this is the presence of errors, such as misspellings in authors' names, which are often present in source documents (Wallin, 2005). We used only the search terms of author name and year in order to minimize the chance that we would miss relevant citations due to reporting errors in source document data. We searched for citation information for publications of all types, not just journal articles. The publications included in our list of publications using GAP data were cited a total of 5,556 times with an average of 8.6 citations per publication. There were 280 publications for which did not yield any citations in our search.

In table 3, we list the publications that have been cited by other publications and the number of citations. Publications are identified by the author(s), year of publication, and the title. Full reference citations for the publications included in this table are provided in the list of references. In the table, the publications are listed in descending order of citation frequency. Only the publications cited at least once were included in this table; not all of the publications that we found that used GAP data are included in this table. 
Table 3. Citation count for publications using GAP data.

\section{Publication Reference}

Citation Count

Homer, Collin; Huang, Chengquan; Yang, Limin; Wylie, Bruce; and Coan, Michael, 2004, Development of a 2001 National Land Cover Database for the United States.

Breshears, D.D., Cobb, N.S., Rich, P.M., Price, K.P., Allen, C.D., Balice, R. G., Romme, W.H., Kastens, J.H., Floyd, M.L., Belnap, Jayne, Anderson, J.J., Myers, O.B., and Meyer, C.W., 2005 , Regional vegetation die-off in response to global-change-type drought.

Church, R.L., Stoms, D.M., and Davis, F.W., 1996, Reserve selection as a maximal covering location problem.

Scott, J.M., Davis, F.W., McGhie, G., Wright, R.G., Groves, C., and Estes, J., 2001, Nature reservesDo they capture the full range of America's biological diversity?

Vogelmann, J.E., Sohl, T.L., Campbell, P.V., and Shaw, D.M., 1998, Regional land cover characterization using Landsat thematic mapper data and ancillary data.

Homer, Collin; Dewitz, Jon; Fry, Joyce; Coan, Michael; Hossain, Nazmul; Larson, Charles; Herold, Nate; McKerrow, Alexa; VanDriel, J.N.; and Wickham, James, 2007, Completion of the 2001 National Land Cover Database for the conterminous United States.

Carroll, Carlos, Noss, R.F. and Paquet, P.C., 2001, Carnivores as focal species for conservation planning in the Rocky Mountain region.

Noss, R.F.; Carroll, Carlos; Vance-Borland, Ken; and Wuerthner, George, 2002, A multicriteria assessment of the irreplaceability and vulnerability of sites in the Greater Yellowstone Ecosystem.

Polasky, Stephen, Camm, J.D., Solow, A.R., Csuti, Blair, White, Denis, and Ding, Rugang, 2000, Choosing reserve networks with incomplete species information.

Guerry, A.D., and Hunter, M.L., Jr., 2002, Amphibian distributions in a landscape of forests and agriculture-An examination of landscape composition and configuration.

Kiester, A.R.; Scott, J.M.; Csuti, Blair; Noss, R.F.; Butterfield, Bart; Sahr, Kevin; and White, Denis, 1996, Conservation prioritization using GAP data.

Theobald, D.M., 2001, Land-use dynamics beyond the American urban fringe.

Guerra, Marta; Walker, Edward; Jones, Carl; Paskewitz, Susan; Cortinas, M.R.; Stancil, Ashley; Beck, Louisa; Bobo, Matthew; and Kitron, Uriel, 2002, Predicting the risk of Lyme Disease-Habitat suitability for Ixodes scapularis in the north central United States.

DeAngelis, D.L., Gross, L.J., Huston, M.A., Wolff, W.F., Fleming, D.M., Comiskey, E.J., and Sylvester, S.M., 1998, Landscape modeling for Everglades ecosystem restoration.

Edwards, T.C., Jr., Deshler, E.T., Foster, Dan, and Moisen, G.G., 1996, Adequacy of wildlife habitat relation models for estimating spatial distributions of terrestrial vertebrates.

Sponseller, R.A., and Benfield, E.F., 2001, Influences of land use on leaf breakdown in southern Appalachian headwater streams - A multiple-scale analysis.

Dark, S.J., 2004, The biogeography of invasive alien plants in California-An application of GIS and spatial regression analysis.

Marshall, C.H., Pielke, R.A., Sr., Steyaert, L.T., and Willard, D.A., 2004, The impact of anthropogenic land-cover change on the Florida peninsula sea breezes and warm season sensible weather.

Moritz, M.A., Keeley, J.E., Johnson, E.A., and Schaffner, A.A., 2004, Testing a basic assumption of shrubland fire management-How important is fuel age? 
Table 3. Citation count for publications using GAP data.-Continued

\section{Publication Reference}

Stoms, D.M., 1994, Scale dependence of species richness maps.

Gitlin, A.R., Sthultz, C.M., Bowker, M.A., Stumpf, Stacy, Paxton, K.L., Kennedy, Karla, Munoz, Axhel, Bailey, J.K., and Whithan, T.G., 2006, Mortality gradients within and among dominant plant populations as barometers of ecosystem change during extreme drought.

Rubbo, M.J., and Kiesecker, J.M., 2005, Amphibian breeding distribution in an urbanized landscape.

Guo, Qinghua, Kelly, Maggi, and Graham, C.H., 2005, Support vector machines for predicting distribution of Sudden Oak Death in California.

Naugle, D.E., Higgins, K.F., Nusser, S.M., and Johnson, W.C., 1999, Scale dependent habitat use in three species of prairie wetland birds.

Huryn, A.D., Butz Huryn, V.M., Arbuckle, C.J., and Tsomides, Leonidas, 2002, Catchment land-use, macroinvertebrates and detrius processing in headwater streams-Taxonomic richness versus function.

Coops, N.C., and Waring, R.H., 2001b, The use of multiscale remote sensing imagery to derive regional estimates of forest growth capacity using 3-PGS.

Frescino, T.S., Edwards, T.C., and Moisen, G.G., 2001, Modeling spatially explicit forest structural attributes using generalized additive models.

Meentemeyer, Ross; Rizzo, David; Mark, Walter; and Lotz, Elizabeth, 2004, Mapping the risk of establishment and spread of Sudden Oak Death in California.

Hubbard, M.W., Danielson, B.J., and Schmitz, R.A., 2000, Factors influencing the location of deervehicle accidents in Iowa.

Carroll, Carlos, Phillips, M.K., Schumaker, N.H., and Smith, D.W., 2003, Impacts of landscape change on wolf restoration success - Planning a reintroduction program based on static and dynamic spatial models.

Naugle, D.E., Johnson, R.R., Estey, M.E., and Higgins, K.F., 2001, A landscape approach to conserving wetland bird habitat in the prairie pothole region of eastern South Dakota.

Westerink, J.J., Luettich, R.A., Feyen, J.C., Atkinson, J.H., Dawson, Clint, Roberts, H.J., Powell, M.D., Dunion, J.P., Kubatko, E.J., and Pourtaheri, Hasan, 2008, A basin- to channel-scale unstructured grid hurricane storm surge model applied to southern Louisiana.

Cushman, S.A., McGarigal, Kevin, and Neel, M.C., 2008, Parsimony in landscape metrics-Strength, universality, and consistency.

Wardlow, B.D., and Egbert, S.L., 2008, Large-area crop mapping using time-series MODIS $250 \mathrm{~m}$ NDVI data-An assessment for the U.S. central Great Plains.

Borak, J.S., and Strahler, A.H., 1999, Feature selection and land cover classification of a MODIS-like data set for a semiarid environment.

DellaSala, D.A., Staus, N.L., Strittholt, J.R., Hackman, Arlin, and Iacobelli, Antonio, 2001, An updated protected areas database for the United States and Canada.

Fraser, R.H., 1998, Vertebrate species richness at the mesoscale-Relative roles of energy and heterogeneity.

Lomolino, M.V., and Smith, G.A., 2001, Dynamic biogeography of prairie dog (Cynomys ludovicianus) towns near the edge of their range.
Citation Count

51

49

49

46

43

41

41

41

39

38

36

34 
Table 3. Citation count for publications using GAP data.-Continued

\section{Publication Reference}

Beard, K.H., Hengartner, Nicolas, and Skelly, D.K., 1999, Effectiveness of predicting breeding bird distributions using probabilistic models.

Coops, N.C., and Waring, R.H., 2001a, Assessing forest growth across southwestern Oregon under a range of current and future global change scenarios using a process model, 3-PG.

Root, K.V., Akçakaya, H.R., and Ginzburg, Lev, 2003, A multispecies approach to ecological valuation and conservation.

Vandergast, A.G., Bohonak, A.J., Weissman, D.B., and Fisher, R.N., 2007, Understanding the genetic effects of recent habitat fragmentation in the context of evolutionary history-Phylogeography and landscape genetics of a southern California endemic Jerusalem cricket (Orthoptera-Stenopelmatidaestenopelmatus).

Boone, J.D., McGwire, K.C., Otteson, E.W., Debaca, R.S., Kuhn, E.A., Villard, Pascal, Brussard, P.F., and St. Jeor, S.C., 2000, Remote sensing and geographic information systems - Charting sin nombre virus infections in deer mice.

Cleland, D.T., Crow, T.R., Saunders, S.C., Dickmann, D.I., Maclean, A.L., Jordan, J.K., Watson, R.L., Sloan, A.M., and Brosofske, K.D., 2004, Characterizing historical and modern fire regimes in Michigan (USA) - A landscape ecosystem approach.

Curnutt, J.L., Comiskey, Jane, Nott, M.P., and Gross, L.J., 2000, Landscape-based spatially explicit species index models for Everglades restoration.

Isaak, D.J., and Hubert, W.A., 2001a, A hypothesis about factors that affect maximum summer stream temperatures across montane landscapes.

Peterson, A.T., and Kluza, D.A., 2003, New distributional modelling approaches for gap analysis.

Theobald, D.M., 2003, Targeting conservation action through assessment of protection and exurban threats.

Stoms, D.M., 2000, GAP management status and regional indicators of threats to biodiversity.

Wolter, P.T., Johnston, C.A., and Niemi, G.J., 2006, Land use land cover change in the U.S. Great Lakes Basin 1992 to 2001.

Parmenter, A.W.; Hansen, Andrew; Kennedy, R.E.; Cohen, Warren; Langner, Ute; Lawrence, Rick; Maxwell, Bruce; Gallant, Alisa; and Aspinall, Richard, 2003, Land use and land cover change in the Greater Yellowstone ecosystem-1975-1995.

Ackerman, Drew, and Schiff, Kenneth, 2003, Modeling storm water mass emissions to the southern California bight.

Sowa, S.P., Annis, Gust, Morey, M.E., and Diamond, D.D., 2007, A gap analysis and comprehensive conservation strategy for riverine ecosystems of Missouri.

Fairbanks, D.H.K., and McGwire, K.C., 2004, Patterns of floristic richness in vegetation communities of California-Regional scale analysis with multi-temporal NDVI.

Franklin, Janet, 2002, Enhancing a regional vegetation map with predictive models of dominant plant species in chaparral.

Staus, N.L., Strittholt, J.R., DellaSala, D.A., and Robinson, Rob, 2002, Rate and pattern of forest disturbance in the Klamath-Siskiyou ecoregion, USA, between 1972 and 1992.
Citation Count

32

32

32

31

31

31

30

30

28

27

26

26

26 
Table 3. Citation count for publications using GAP data.-Continued

\section{Publication Reference}

Brooks, R.P., Wardrop, D.H., and Bishop, J.A., 2004, Assessing wetland condition on a watershed basis in the Mid-Atlantic region using synoptic land-cover maps.

Davis, F.W., Stoms, D.M., and Andelman, Sandy, 1999, Systematic reserve selection in the USA-An example from the Columbia Plateau ecoregion.

Feist, B.E., Steel, E.A., Pess, G.R., and Bilby, R.E., 2003, The influence of scale on salmon habitat restoration priorities.

Germino, M.J., Reiners, W.A., Blasko, B.J., McLeod, Donald, and Bastian, C.T., 2001, Estimating visual properties of Rocky Mountain landscapes using GIS.

Groves, C.R., Kutner, L.S., Stoms, D.M., Murray, M.P., Scott, J.M., Schafale, Michael, Weakley, A.S., and Pressey, R.L., 2000, Owning up to our responsibilities - Who owns lands important for biodiversity.

Leu, Matthias, Hanser, S.E., and Knick, S.T., 2008b, The human footprint in the West—A large-scale analysis of anthropogenic impacts.

Wright, R.G., MacCracken, J.G., and Hall, Joel, 1994, An ecological evaluation of proposed new conservation areas in Idaho_-Evaluating proposed Idaho national parks.

Crist, P.J., Kohley, T.W., and Oakleaf, John, 2000, Assessing land-use impacts on biodiversity using an expert systems tool.

Gillespie, T.W., 2005, Predicting woody-plant species richness in tropical dry forests-A case study from south Florida, USA.

Haight, R.G., Cleland, D.T., Hammer, R.B., Radeloff, V.C., and Rupp, T.S., 2004, Assessing fire risk in the wildland-urban interface.

Pratt, P.D., Slone, D.H., Rayamajhi, M.B., Van, T.K., and Center, T.D., 2003, Geographic distribution and dispersal rate of Oxyops vitiosa (Coleoptera-Curculionidae), a biological control agent of the invasive tree Melaleuca quinquenervia in south Florida.

Stoms, D.M., and Hargrove, W.W., 2000, Potential NDVI as a baseline for monitoring ecosystem functioning.

Shriner, S.A., Wilson, K.R., and Flather, C.H., 2006, Reserve networks based on richness hotspots and representation vary with scale.

Williams, J.W., Seabloom, E.W., Slayback, Daniel, Stoms, D.M., and Viers, J.H., 2005, Anthropogenic impacts upon plant species richness and net primary productivity in California.

Wright, R.G., Murray, M.P., and Merrill, Troy, 1998, Ecoregions as a level of ecological analysis.

Adjemian, J.C.Z., Girvetz, E.H., Beckett, Laurel, and Foley, J.E., 2006, Analysis of genetic algorithm for rule-set production (GARP) modeling approach for predicting distributions of fleas implicated as vectors of plague, Yersinia pestis, in California.

Eisen, R.J., Lane, R.S., Fritz, C.L., Eisen, Lars, 2006, Spatial patterns of Lyme disease risk in California based on disease incidence data and modeling of vector-tick exposure.

Peterson, E.B., 2005, Estimating cover of an invasive grass (Bromus tectorum) using tobit regression and phenology derived from two dates of Landsat ETM+ data.

Bajema, R.A., and Lima, S.L., 2001, Landscape-level analyses of Henslow's Sparrow (Ammodramus henslowii) abundance in reclaimed coal mine grasslands.
Citation Count

24

24

24

24

24

24

24

23

23

23

23

22

22

22

21

21

21

20 
Table 3. Citation count for publications using GAP data.-Continued

\section{Publication Reference}

Bajema, R.A., DeVault, T.L., Scott, P.E., and Lima, S.L., 2001, Reclaimed coal mine grasslands and their significance for Henslow's Sparrows in the American Midwest.

Bond, J. E., Beamer, D.A., Lamb, T., and Hedin, M., 2006, Combining genetic and geospatial analyses to infer population extinction in mygalomorph spiders endemic to the Los Angeles region.

Dietz, R.W., and Czech, Brian, 2005, Conservation deficits for the continental United States-An ecosystem gap analysis.

Kelley, Chris; Garson, Justin; Aggarwal, Anshu; and Sarkar, Sahotra, 2002, Place prioritization for biodiversity reserve network design-A comparison of the SITES and ResNet software packages for coverage and efficiency.

Driese, K.L., Reiners, W.A., Merrill, E.H., and Gerow, K.G., 1997, A digital land cover map of Wyoming, USA-A tool for vegetation analysis.

Grand, Joanna, Buonaccorsi, John, Cushman, S.A., Griffin, C.R., and Neel, M.C., 2004, A multiscale landscape approach to predicting bird and moth rarity hotspots in a threatened pitch pine-scrub oak community.

Walker, Richard, and Craighead, Lance, 1997, Analyzing wildlife movement corridors in Montana using GIS.

Westrick, K.J., Storck, Pascal, and Mass, C.F., 2002, Description and evaluation of a hydrometeorological forecast system for mountainous watersheds.

Murphy, H.T., and Lovett-Doust, Jon, 2007, Accounting for regional niche variation in habitat suitability models.

Rodman, L.C., and Meentemeyer, R.K., 2006, A geographic analysis of wind turbine placement in northern California.

Eisen, R.J.; Enscore, R.E.; Biggerstaff, B.J.; Reynolds, P.J.; Ettestad, Paul; Brown, Ted; Pape, John;

Tanda, Dale; Levy, C.E.; Engelthaler, D.M.; Cheek, James; Bueno, Rudy, Jr.; Targhetta, Joseph;

Montenieri, J.A.; and Gage, K.L., 2007, Human plague in the southwestern United States, 1957-2004-

Spatial models of elevated risk of human exposure to Yersinia pestis.

Gustafson, E.J., Knutson, M.G., Niemi, G.J., and Friberg, Mary, 2002, Evaluation of spatial models to predict vulnerability of forest birds to brood parasitism by cowbirds.

Secchi, Silvia; Tyndall, John; Schulte, L.A.; and Asbjornsen, Heidi, 2008, High crop prices and conservation.

Wells, M.L.; O'Leary, J.F.; Franklin, Janet; Michaelsen, Joel; and McKinsey, D.E., 2004, Variations in a regional fire regime related to vegetation type in San Diego County, California (USA).

White, Denis, Preston, E.M., Freemark, K.E., and Kiester, A.R., 1999, A hierarchical framework for conserving biodiversity.

DiMauro, Danielle, and Hunter, M.L., Jr., 2002, Reproduction of amphibians in natural and anthropogenic temporary pools in managed forests.

Millar, C.I., King, J.C., Westfall, R.D., Alden, H.A., and Delany, D.L., 2006, Late holocene forest dynamics, volcanism, and climate change at Whitewing Mountain and San Joaquin Ridge, Mono County, Sierra Nevada, CA, USA.
Citation Count

20

20

20

18

16 
Table 3. Citation count for publications using GAP data.-Continued

\section{Publication Reference}

Miller, S.J., Wardrop, D.H., Mahaney, W.M., and Brooks, R.P., 2006, A plant-based index of biotic integrity (IBI) for headwater wetlands in central Pennsylvania.

Naugle, D.E., Higgins, K.F., Estey, M.E., Johnson, R.R., and Nusser, S.M., 2000, Local and landscapelevel factors influencing black tern habitat suitability.

Rao, Mahesh; Fan, Guoliang; Thomas, Johnson; Cherian, Ginto; Chudiwale, Varun; and Awawdeh, Muheeb, 2007, A web-based GIS decision support system for managing and planning USDA's conservation reserve program (CRP).

Rumsey, David, and Williams, Meredith, 2002, Historical maps in GIS.

Stoms, D.M., Davis, F.W., Driese, K.L., Cassidy, K.M., and Murray, M.P., 1998, Gap analysis of the vegetation of the intermountain semi-desert ecoregion.

Witty, J.H., Graham, R.C., Hubbert, K.R., Doolittle, J.A., and Wald, J.A., 2003, Contributions of water supply from the weathered bedrock zone to forest soil quality.

Dees, C.S., Clark, J.D., and Van Manen, F.T., 2001, Florida panther habitat use in response to prescribed fire.

Janis, M.W., and Clark, J.D., 2002, Responses of Florida panthers to recreational deer and hog hunting.

Jovan, Sarah, and McCune, Bruce, 2005, Air-quality bioindication in the greater central valley of California, with epiphytic macrolichen communities.

Logan, J.A., Regniere, J., Gray, D.R., and Munson, A.S., 2007, Risk assessment in the face of a changing environment - Gypsy moth and climate change in Utah.

Murray, L.D., and Best, L.B., 2003, Short-term bird response to harvesting switchgrass for biomass in Iowa.

Sullivan, T.J., Fernandez, I.J., Herlihy, A.T., Driscoll, C.T., McDonnell, T.C., Nowicki, N.A., Snyder, K.U., and Sutherland, J.W., 2006, Acid-base characteristics of soils in the Adirondack Mountains, New York.

Zhan, Xiaoyong, and Huang, M.L., 2004, ArcCN-Runoff-An ArcGIS tool for generating curve number and runoff maps.

Dauwalter, D.C., and Pert, E.J., 2003, Electrofishing effort and fish species richness and relative abundance in Ozark highland streams of Arkansas.

Hunter, J.C., Willett, K.B., McCoy, M.C., Quinn, J.F., and Keller, K.E., 1999, Prospects for preservation and restoration of riparian forests in the Sacramento Valley, California, USA.

Menking, K.M., Anderson, R.Y., Shafike, N.G, Syed, K.H., and Allen, B.D., 2004, Wetter or colder during the Last Glacial Maximum? - Revisiting the pluvial lake question in southwestern North America.

Pitman, J.C., Hagen, C.A., Robel, R.J., Loughin, T.M., and Applegate, R.D., 2005, Location and success of lesser prairie-chicken nests in relation to vegetation and human disturbance.

Eisen, R.J.; Reynolds, P.J.; Ettestad, Paul; Brown, Ted; Enscore, R.E.; Biggerstaff, B.J.; Cheek, James;

Bueno, Rudy; Targhetta, Joseph; Montenieri, J.A.; and Gage, K.L., 2007, Residence-linked human plague in New Mexico-A habitat-suitability model.
Citation Count

16

16

16

16

16

16

15

15

15

15

15

14

14

14 


\section{Table 3. Citation count for publications using GAP data.-Continued}

\section{Publication Reference}

Grivet, Delphine, Sork, V.L., Westfall, R.D., and Davis, F.W., 2008, Conserving the evolutionary potential of California valley oak (Quercus lobata Née) - A multivariate genetic approach to conservation planning.

Merrill, Troy, Wright, R.G., and Scott, J.M., 1995, Using ecological criteria to evaluate wilderness planning options in Idaho.

Morrison, J.L., and Humphrey, S.R., 2001, Conservation value of private lands for Crested Caracaras in Florida.

Thogmartin, W.E., 1999, Landscape attributes and nest-site selection in wild turkeys.

Triant, D.A., Pace, R.M., and Stine, Michael, 2004, Abundance, genetic diversity, and conservation of Louisiana black bears (Ursus americanus luteolus) as detected through noninvasive sampling.

Wright, R.G., Scott, J.M., Mann, Shannon, and Murray, Michael, 2001, Identifying unprotected and potentially at risk plant communities in the Western USA.

Clinton, N.E., Gong, Peng, and Scott, Klaus, 2006, Quantification of pollutants emitted from very large wildland fires in southern California, USA.

Crist, M.R., Wilmer, Bo, and Aplet, G.H., 2005, Assessing the value of roadless areas in a conservation reserve strategy - Biodiversity and landscape connectivity in the northern Rockies.

Eisen, R.J.; Glass, G.E.; Eisen, Lars; Cheek, James; Enscore, R.E.; Ettestad, Paul; and Gage, K.L., 2007, A spatial model of shared risk for plague and hantavirus pulmonary syndrome in the southwestern United States.

Frizzelle, B.G., and Moody, Aaron, 2001, Mapping continuous distributions of land cover-A comparison of maximum-likelihood estimation and artificial neural networks.

Jiang, Hong, Strittholt, J.R., Frost, P.A., and Slosser, N.C., 2004, The classification of late seral forests in the Pacific Northwest, USA, using Landsat ETM+ imagery.

Sloat, M.R., Shepard, B.B., White, R.G., and Carson, Steve, 2005, Influence of stream temperature on the spatial distribution of westslope cutthroat trout growth potential within the Madison River basin, Montana.

Underwood, E.C., Klaumeyer, K.R., Cox, R.L., Busby, S.M., Morrison, S.A., and Shaw, M.R., 2009, Expanding the global network of protected areas to save the imperiled Mediterranean biome.

Pu, R., Gong, P., Li, Z., and Scarborough, J., 2004, A dynamic algorithm for wildfire mapping with NOAA/AVHRR data.

Scott, K.I., and Benjamin, M.T., 2003, Development of a biogenic volatile organic compounds emission inventory for the SCOS97-NARSTO domain.

Stralberg, Diana; Jongsomjit, Dennis; Howell, C.A.; Snyder, M.A.; Alexander, J.D.; Wiens, J.A.; and Root, T.L., 2009, Re-shuffling of species with climate disruption-A no-analog future for California birds?

Thogmartin, W.E., and Schaeffer, B.A., 2000, Landscape attributes associated with mortality events of wild turkeys in Arkansas.

Bassett, S.D., and Edwards, T.C., Jr., 2003, Effect of different sampling schemes on the spatial placement of conservation reserves in Utah, USA.
Citation Count

12 


\section{Table 3. Citation count for publications using GAP data.-Continued}

\section{Publication Reference}

Citation Count

Bradley, B.A., and Mustard, J.F., 2008, Comparison of phenology trends by land cover class-A case study in the Great Basin, USA.

Bunya, S., Dietrich, J.C., Westerink, J.J., Ebersole, B.A., Smith, J.M., Atkinson, J.H., Jensen, R., Resio, D.T., Luettich, R.A., Dawson, C., Cardone, V.J., Cox, A.T., Powell, M.D., Westerink, H.J., and Roberts, H.J., 2010, A high-resolution coupled riverine flow, tide, wind, wind wave, and storm surge model for southern Louisiana and Mississippi-Part I-model development and validation.

Clark, F.S., and Slusher, R.B., 2000, Using spatial analysis to drive reserve design-A case study of a national wildlife refuge in Indiana and Illinois (USA).

Didier, K.A., and Porter, W.F., 1999, Large-scale assessment of potential habitat to restore elk to New York State.

Ford, T.B., Winslow, D.E., Whitehead, D.R., and Koukol, M.A., 2001, Reproductive success of forestdependent songbirds near an agricultural corridor in south-central Indiana.

Laurent, E.J.; Shi, Haijin; Gatziolix, Demetrios; LeBouton, J.P.; Walters, M.B.; and Liu, Jianguo, 2005, Using the spatial and spectral precision of satellite imagery to predict wildlife occurrence patterns.

Mau-Crimmins, Theresa, de Steiguer, J.E., and Dennis, Donald, 2005, AHP as a means for improving public participation-A pre-post experiment with university students.

McClain, B.J., and Porter, W.F., 2000, Using satellite imagery to assess large-scale habitat characteristics of Adirondack Park, New York, USA.

Peterson, A.T., 2005, Kansas Gap Analysis-The importance of validating distributional models before using them.

Pyke, C.R., 2005a, Assessing climate change impacts on vernal pool ecosystems and endemic branchiopods.

Rasmussen, Craig, 2006, Distribution of soil organic and inorganic carbon pools by biome and soil taxa in Arizona.

Singleton, P.H., Gaines, W.L., and Lehmkuhl, J.F., 2004, Landscape permeability for grizzly bear movements in Washington and southwestern British Columbia.

Thorne, J.H., Cameron, Dick, and Quinn, J.F., 2006, A conservation design for the central coast of California and the evaluation of mountain lion as an umbrella species.

Wardlow, B.D., and Egbert, S.L., 2003, A state-level comparative analysis of the GAP and NLCD landcover data sets.

Allen, C.R., Johnson, A.R., Parris, Leslie, 2006, A framework for spatial risk assessments-Potential impacts of nonindigenous invasive species on native species.

Fuller, M.M., Gross, L.J., Duke-Sylvester, S.M., and Palmer, Mark, 2008, Testing the robustness of management decisions to uncertainty—Everglades restoration scenarios.

Gerrard, R.A., Church, R.L., Stoms, D.M., and Davis, F.W., 1997, Selecting conservation reserves using species-covering models-Adapting the ARC/INFO GIS.

Hansen, M.H., and Wendt, D.G., 2000, Using classified Landsat thematic mapper data for stratification in a statewide forest inventory.

Hudak, P.F., and Sanmanee, Sirichai, 2003, Spatial patterns of nitrate, chloride, sulfate, and fluoride concentrations in the Woodbine aquifer of north-central Texas.
10

0 10 
Table 3. Citation count for publications using GAP data.-Continued

\section{Publication Reference}

Isaak, D.J., and Hubert, W.A., 2001b, Production of stream habitat gradients by montane watershedsHypothesis tests based on spatially explicit path analyses.

Lee, Hyongki; Shum, C.K.; Yi, Yuchan; Ibaraki, Motomu; Kim, Jin-Woo; Braun, Alexander; Kuo, Chung-Yen.; and Lu, Zhong, 2009, Louisiana wetland water level monitoring using retracked TOPEX/POSEIDON altimetry.

Lipow, S.R., Vance-Borland, Kenneth, St. Clair, J.B., Henderson, Jan, and McCain, Cindy, 2004, Gap analysis of conserved genetic resources for forest trees.

Parajuli, P.B., Mankin, K.R., and Barnes, P.L., 2008, Applicability of targeting vegetative filter strips to abate fecal bacteria and sediment yield using SWAT.

Parajuli, P.B., Mankin, K.R., and Barnes, P.L., 2009, Source specific fecal bacteria modeling using soil and water assessment tool model.

Sarkar, Sahotra, and Garson, Justin, 2004, Multiple criterion synchronisation for conservation area network design-The use of non-dominated alternative sets.

Sork, V.L.; Davis F.W.; Westfall, Robert; Flint, Alan; Ikegami, Makihiko; Wang, Hongfang; and Grivet, Delphine, 2010, Gene movement and genetic association with regional climate gradients in California valley oak (Quercus lobata Née) in the face of climate change.

Woolmer, Gillian, Trombulak, S.C., Ray, J.C., Doran, P.J., Anderson, M.G., Baldwin, R.F., Morgan, Alexis, and Sanderson, E.W., 2008, Rescaling the human footprint-A tool for conservation planning at an ecoregional scale.

Brenner, John; Paustian, Keith; Bluhm, George; Cipra, Jan; Easter, Mark; Killian, Kendrick; Schuler, Jill; Smith, Phil; and Williams, Steve, 2001, Phase I progress report-Quantifying the change in greenhouse gas emissions due to natural resource conservation practice application in Nebraska.

Mitchell, J.E., and Roberts, T.C., Jr., 1999, Distribution of pinyon-juniper in the Western United States.

Monahan, W.B., and Koenig, W.D., 2006, Estimating the potential effects of Sudden Oak Death on oakdependent birds.

Norris, J.R., Jackson, S.T., and Betancourt, J.L., 2006, Classification tree and minimum-volume ellipsoid analyses of the distribution of ponderosa pine in the Western USA.

Rabe, M.J., Rosenstock, S.S., and Nielsen, D.I., 2005, Feral africanized honey bees (Apis mellifere) in Sonoran desert habitats of southwestern Arizona.

Daggett, Steve; Boule', Marc; Bernert, J.A.; Eilers, J.M.; Blok, Elaine; Peters, Dennis; and Morlan, J.C., 1998, Wetland and land use change in the Willamette Valley, Oregon-1982-1994, Volume 1, Final report.

Ekness, Paul, and Randhir, Timothy, 2007, Effects of riparian areas, stream order, and land use disturbance on watershed-scale habitat potential —An ecohydrological approach to policy.

Hoffman, J.D., Narumalani, Sunil, Mishra, D.R., Merani, Paul, and Wilson, R.G., 2008, Predicting potential occurrence and spread of invasive plant species along the North Platte River, Nebraska.

Kocovsky, P.M., and Carline, R.F., 2006, Influence of landscape-scale factors in limiting brook trout populations in Pennsylvania streams.

Larson, B.D., and Sengupta, R.R., 2004, A spatial decision support system to identify species-specific critical habitats based on size and accessibility using US GAP data.
Citation Count 


\section{Table 3. Citation count for publications using GAP data.-Continued}

\section{Publication Reference}

Menzel, J.M., Ford, W.M., Edwards, J.W., Ceperley, L.J., 2006, A habitat model for the Virginia northern flying squirrel (Glaucomys sabrinus fuscus) in the central Appalachian Mountains.

Moritz, M.A., and Odion, D.C., 2005, Examining the strength and possible causes of the relationship between fire history and Sudden Oak Death.

Parés-Ramos, I.K., Gould, W.A., and Aide, T.M., 2008, Agricultural abandonment, suburban growth, and forest expansion in Puerto Rico between 1991 and 2000.

Rachlow, J.L., and Svancara, L.K., 2006, Prioritizing habitat for surveys of an uncommon mammal-A modeling approach applied to pygmy rabbits.

Salmon, Olivia; Brunson, Mark; and Kuhns, Michael, 2006, Benefit-based audience segmentation-A tool for identifying nonindustrial private forest owner education needs.

Snyder, S.A., Whitmore, J.H., Schneider, I.E., and Becker, D.R., 2008, Ecological criteria, participant preferences and location models-A GIS approach toward ATV trail planning.

St-Louis, Véronique, Pidgeon, A.M., Clayton, M.K., Locke, B.A., Bash, Dallas, and Radeloff, V.C., 2009, Satellite image texture and a vegetation index predict avian biodiversity in the Chihuahuan Desert of New Mexico.

Beck, J.L., Reese, K.P., Connelly, J.W., and Lucia, M.B., 2006, Movements and survival of juvenile greater sage-grouse in southeastern Idaho.

Dauwalter, D.C., and Jackson, J.R., 2004, A provisional fish index of biotic integrity for assessing Ouachita mountains streams in Arkansas, USA.

Doren, R.F., Rutchey, Ken, and Welch, Roy, 1999, The Everglades-A perspective on the requirements and applications for vegetation map and database products.

Fecske, D.M., Jenks, J.A., and Smith, V.J., 2002, Field evaluation of a habitat-relation model for the American marten.

Huang, Cho-ying, Asner, G.P., Martin, R.E., Barger, N.N., and Neff, J.C., 2009, Multiscale analysis of tree cover and aboveground carbon stocks in pinyon-juniper woodland.

King, D.T., and Michot, T.C., 2002, Distribution, abundance and habitat use of American white pelicans in the delta region of Mississippi and along the western Gulf of Mexico coast.

Larrucea, E.S., and Brussard, P.F., 2008, Habitat selection and current distribution of the pygmy rabbit in Nevada and California, USA.

Liu, Zhongwei, Volin, J.C., Owen, V.D., Pearlstine, L.G., Allen, J.R., Mazzotti, F.J., and Higer, A.L., 2009, Validation and ecosystem applications of the EDEN water-surface model for the Florida Everglades.

Moen, Ron, Burdett, C.L., and Niemi, G.J., 2008, Movement and habitat use of Canada lynx during denning in Minnesota.

Pease, K.M.; Freedman, A.H.; Pollinger, J.P.; McCormack, J.E.; Buermann, Wolfgang; Rodzen, Jeff; Banks, Jim; Meredith, Erin; Bleich, V.C.; Schaefer, R.J.; Jones, Ken; and Wayne, R.K., 2009, Landscape genetics of California mule deer (Odocoileus hemionus) - the roles of ecological and historical factors in generating differentiation.

Pyke, C.R., 2005b, Interactions between habitat loss and climate change-Implications for fairy shrimp in the central valley ecoregion of California, USA.
Citation Count

7

7

7

7

7

7

7

6

6

6

6

6

6

6

6 
Table 3. Citation count for publications using GAP data.-Continued

\section{Publication Reference}

Shriver, D.M., and Randhir, T.O., 2006, Integrating stakeholder values with multiple attributes to quantify watershed performance.

Strickland, B.K., and Demarais, Stephen, 2008, Influence of landscape composition and structure on antler size of white-tailed deer.

Beckage, Brian; Comiskey, Jane; and Duke-Sylvester, Scott, 2005, Response to Maehr and LarkinNatural fire regimes in southern Florida.

Bradley, B.A., 2010, Assessing ecosystem threats from global and regional change-Hierarchical modeling of risk to sagebrush ecosystems from climate change, land use and invasive species in Nevada, USA.

Burns, K.S., Schoettle, A.W., Jacobi, W.R., and Mahalovich, M.F., 2008, Options for the management of white pine blister rust in the Rocky Mountain region.

Buyantuyev, A., and Wu, J., 2009, Urbanization alters spatiotemporal patterns of ecosystem primary production-A case study of the Phoenix metropolitan region, USA.

Dauwalter, D.C., Pert, E.J., and Keith, W.E., 2003, An index of biotic integrity for fish assemblages in Ozark highland streams of Arkansas.

Dean, D.J., Wilson, K.R., and Flather, C.H., 1997, Spatial error analysis of species richness for a Gap Analysis map.

Efroymson, R.A.; Dale, V.H.; Baskaran, L.M.; Chang, Michael; Aldridge, Matthew; and Berry, M.W., 2005, Planning transboundary ecological risk assessments at military installations.

Goheen, E.M., Hansen, E., Kanaskie, A., Osterbauer, N., Parke, J., Pscheidt, J., and Chastagner, G., 2006, Sudden Oak Death and Phytophthora ramorum - A guide for forest managers, Christmas tree growers, and forest-tree nursery operators in Oregon and Washington.

Gori, D.F., and Enquist, C.A.F., 2003, An assessment of the spatial extent and condition of grasslands in central and southern Arizona, southwestern New Mexico and northern Mexico.

Heathman, G.C., Larose, M., and Ascough, J.C., 2009, Soil and water assessment tool evaluation of soil and land use geographic information system data sets on simulated stream flow.

Hopton, M.E., and Mayer, A.L., 2006, Using self-organizing maps to explore patterns in species richness and protection.

Huang, Cho-ying, and Geiger, E.L., 2008, Climate anomalies provide opportunities for large-scale mapping of non-native plant abundance in desert grasslands.

Jacobs, B.F., Romme, W.H., and Allen, C.D., 2008, Mapping old versus young piñon-juniper stands with a predictive topo-climatic model in north-central New Mexico, USA.

Kanda, L.L., Fuller, T.K., Sievert, P.R., and Kellogg, R.L., 2009, Seasonal source-sink dynamics at the edge of a species' range.

Lindell, C.A., McCullough, D.G., Cappaert, David, Apostolou, N.M., and Roth, M.B., 2008, Factors influencing woodpecker predation on emerald ash borer.

Love, J.W., and May, E.B., 2007, Relationships between fish assemblage structure and selected environmental factors in Maryland's coastal bays.

Martin, August, Gunter, J.T., and Regens, J.L., 2003, Estimating erosion in a riverine watershedBayou Liberty-Tchefuncta river in Louisiana.
Citation Count

6

6

5

5

5

5

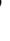

5

5

5

5

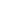

5

5

5

5

5

5

5

5

5 
Table 3. Citation count for publications using GAP data.-Continued

Publication Reference

Maxwell, S.K., Hoffer, R.M. and Chapman, P.L., 2002, AVHRR composite period selection for land cover classification.

Menking, K.M., Syed, K.H., Anderson, R.Y., Shafike, N.G., and Arnold, J.G., 2003, Model estimates of runoff in the closed, semiarid Estancia basin, central New Mexico, USA.

Roth, J.E., Kelly, J.P., Sydeman, W.J., and Colwell, M.A., 2004, Sex differences in space use of breeding common ravens in western Marin County, California.

Shirk, A.J., Wallin, D.O., Cushman, S.A., Rice, C.G., and Warheit, K.I., 2010, Inferring landscape effects on gene flow-A new model selection framework.

Stoms, D.M., Bueno, M.J., Davis, F.W., Cassidy, K.M., Driese, K.L., and Kagan, J.S., 1998, Mapguided classification of regional land cover with multi-temporal AVHRR data.

Teels, B.M., Rewa, C.A., and Myers, John, 2006, Aquatic condition response to riparian buffer establishment.

Wamsley, T.V., Cialone, M.A., Smith, J.M., Atkinson, J.H., and Rosati, J.D., 2010, The potential of wetlands in reducing storm surge.

Alfieri, J.G.; Niyogi, Dev; LeMone, M.A.; Chen, Fei; and Fall, Souleymane, 2007, A simple reclassification method for correcting uncertainty in land use/land cover data sets used with land surface models.

Bauer, M.E., Loeffelholz, Brian, and Wilson, Bruce, 2005, Estimation, mapping, and change analysis of impervious surface area by Landsat remote sensing.

Bauer, M.E., Loeffelholz, B.C., Wilson, Bruce, 2007, Estimating and mapping impervious surface area by regression analysis of Landsat imagery.

Chen, Y.D., McCutcheon, S.C., Carsel, R.F., Donigian, A.S., Jr., Cannell, J.R., and Craig, J.P., 1995, Validation of HSPF for the water balance simulation of the Upper Grande Ronde watershed, Oregon, USA.

Diamond, D.D., True, C.D., Gordon, T.M., Sowa, S.P., Foster, W.E., and Jones, B.K., 2005, Influence of targets and assessment region size on perceived conservation priorities.

Falzarano, S.R., and Thomas, K.A., 2004, Fuzzy set and spatial analysis techniques for evaluating thematic accuracy of a land-cover map.

Greenwood, D.L., and Weisberg, P.J., 2009, GIS-based modeling of pinyon-juniper woodland structure in the Great Basin.

Gregory, C.J., Carthy, R.R., and Pearlstine, L.G., 2006, Survey and monitoring of species at risk at Camp Blanding training site, northeastern Florida.

Howell, J.E., Peterson, J.T., and Conroy, M.J., 2008, Building hierarchical models of avian distributions for the state of Georgia.

Kim, Jin-Woo; Lu, Zhong; Lee, Hyongki; Shum, C.K.; Swarzenski, C.M.; Doyle, T.W.; and Baek, Sang-Ho, 2009, Integrated analysis of PALSAR/Radarsat-1 InSAR and ENVISAT altimeter data for mapping of absolute water level changes in Louisiana wetlands.

Mahan, C.G., and O'Connell, T.J., 2005, Small mammal use of suburban and urban parks in central Pennsylvania.
Citation Count

5

5

5

5

5

5

5

4

4

4

4

4

4

4

4

4 
Table 3. Citation count for publications using GAP data.-Continued

Publication Reference

Mattice, J.A., Brauning, D.W., and Diefenbach, D.R., 2005, Abundance of grassland sparrows on reclaimed surface mines in western Pennsylvania.

Riitters, K.H., Coulston, J.W., and Wickham, J.D., 2003, Localizing national fragmentation statistics with forest type maps.

Roth, T.C., II, Vetter, W.E., and Lima, S.L., 2008, Spatial ecology of winting accipiter hawks-Home range, habitat use, and the influence of bird feeders.

Sacks, B.N., Chomel, B.B., and Kasten, R.W., 2004, Modeling the distribution and abundance of the non-native parasite, canine heartworm, in California coyotes.

Stein, B.A.; Scott, Cameron; and Benton, Nancy, 2008, Federal lands and endangered species-The role of military and other federal lands in sustaining biodiversity.

Taft, O.W, Haig, S.M., and Kiilsgaard, Chris, 2004, Use of radar remote sensing (RADARSAT) to map winter wetland habitat for shorebirds in an agricultural landscape.

Telesco, R.L., Van Manen, F.T., Clark, J.D., and Cartwright, M.E., 2007, Identifying sites for elk restoration in Arkansas.

Thorne, J.H., Morgan, B.J., and Kennedy, J.A., 2008, Vegetation change over sixty years in the central Sierra Nevada, California, USA.

Trapp, J.R., 2004, Wolf den site selection and characteristics in the northern Rocky Mountains-A multi-scale analysis.

Wade, A.A., and Theobald, D.M., 2010, Residential development encroachment on U.S. protected areas.

Wang, Dali, Carr, Eric, Gross, L.J., and Berry, M.W., 2005, Toward ecosystem modeling on computing grids.

Yanoff, Steven, and Muldavin, Esteban, 2008, Grassland-shrubland transformation and grazing-A century-scale view of a northern Chihuahuan Desert grassland.

Benjamin, M.T.; Winer, A.M.; Karlik, John; Campbell, Skip; Jackson, Bruce; and Lashgari, Ash, 1998, Assembling a biogenic hydrocarbon emissions inventory for the SCOS97-NARSTO modeling domain.

Caratti, J.F., 2006, The LANDFIRE Prototype Project reference database.

Conway, C.J., and Kirkpatrick, Chris, 2007, Effect of forest fire suppression on buff-breasted flycatchers.

Crowe, R.E., 1996, Use of gap analysis in regional planning in southern California.

Dilts, T.E., Sibold, J.S., and Biondi, Franco, 2009, A weights-of-evidence model for mapping the probability of fire occurrence in Lincoln County, Nevada.

Gunter, J.T., Hodges, D.G., and Regens, J.L., 2005, Probability models for predicting local water quality regulations in the southern United States.

Jones, J.W., and Price, S.D., 2007, Conceptual design of the Everglades Depth Estimation Network (EDEN) grid.

Lennartz, Steven, 2005, Oregon forest land change mapping.

Manier, D.J., Hobbs, N.T., Theobald, D.M., Reich, R.M., Kalkhan, M.A., and Campbell, M.R., 2005,

Canopy dynamics and human caused disturbance on a semi-arid landscape in the Rocky Mountains, USA.
Citation Count

4

4

4

4

4

4

4

4

4

4

4

4

3

3

3

3

3

3

3

3

3 
Table 3. Citation count for publications using GAP data.-Continued

\section{Publication Reference}

Matocq, M.D., and Murphy, P.J., 2007, Fine-scale phenotypic change across a species transition zone in the genus Neotoma-Disentangling independent evolution from phylogenetic history.

Nesslage, G.M., Maurer, B.A., and Gage, S.H., 2007, Gypsy moth response to landscape structure differs from neutral model predictions-Implications for invasion monitoring.

Oleson, K.W., Driese, K.L., Maslanik, J.A., Emery, W.J., and Reiners, W.A., 1997, The sensitivity of a land surface parameterization scheme to the choice of remotely sensed land-cover datasets.

Parajuli, P.B., Douglas-Mankin, K.R., Barnes, P.L., and Rossi, C.G., 2009, Fecal bacteria source characterization and sensitivity analysis of SWAT 2005.

Peterson, D.L., Egbert, S.L., Price, K.P., and Martinko, E.A., 2004, Identifying historical and recent land-cover changes in Kansas using postclassification change detection techniques.

Peterson, E.B., 2006, A map of invasive annual grasses in Nevada derived from multitemporal Landsat 5 TM imagery.

Ramsey, Elijah, III; Rangoonwala, Amina; Middleton, Beth; and Lu, Zhong, 2009, Satellite optical and radar data used to track wetland forest impact and short-term recovery from Hurricane Katrina.

Rimmer, C.C., McFarland, K. P., Lambert, J.D., and Renfrew, R.B., 2004, Evaluating the use of Vermont ski areas by Bicknell's Thrush_Applications for Whiteface Mountain, New York.

Sader, S.A., and Legaard, K.R., 2008, Inclusion of forest harvest legacies, forest type, and regeneration spatial patterns in updated forest maps-A comparison of mapping results.

Schumacher, J.V., Redmond, R.L., Hart, M.M., and Jensen, M.E., 2000, Mapping patterns of human use and potential resource conflicts on public lands.

Stoner, D.C., Rieth, W.R., Wolfe, M.L., Mecham, M.B., and Neville, Ann, 2008, Long-distance dispersal of a female cougar in a basin and range landscape.

Storm, D.E., White, Michael, Smolen, M.D., and Zhang, Hailin, 2001, Modeling phosphorous loading for the Lake Eucha Basin-Final report.

Thatcher, C.A., Van Manen, F.T., and Clark, J.D., 2009, A habitat assessment for Florida panther population expansion into central Florida.

Theobald, D.M., Norman, J.B., and Sherburne, M.R., 2006, FunConn v1 user's manual-ArcGIS tools for functional connectivity modeling.

Thompson, B.C., Hughes, M.A., and Anderson, M.C., 2001, Effects of including non-breeding bird species on predicted bird distributions for conservation planning in New Mexico.

Thorne, J.H.; Kennedy, J.A.; Quinn, J.F.; McCoy, Michael; Keeler-Wolf, Todd; and Menke, John, 2004, A vegetation map of Napa County using the Manual of California Vegetation Classification and its comparison to other digital vegetation maps.

van Leeuwen, W.J.D., 2008, Monitoring the effects of forest restoration treatments on post-fire vegetation recovery with MODIS multitemporal data.

Volin, J.C.; Liu, Zhongwei; Higer, Aaron; Mazzotti, Frank; Owen, Dianne; Allen, Jenny; and Pearlstine, Leonard, 2008, Validation of a spatially continuous EDEN water-surface model for the Everglades, Florida.
Citation Count

3

3

3

3

3

3

3

3

3

3

3

3

3

3

3

3

3 


\section{Table 3. Citation count for publications using GAP data.-Continued}

Publication Reference

Weber, T.C., 2007, Development and application of a statewide conservation network in Delaware, U.S.A.

Allen, K.E., Bradley, R.D., Monk, R.R., Knyazhnitskiy, O.V., Parker, N.C., Schmidly, D.J., and Baker, R.J., 2001, Employment of geographic information systems for determining the accuracy of museum voucher specimen data.

Barrow, Wylie, Jr.; Buler, J.; Couvillion, Brady; Diehl, Robb; Faulkner, Stephen; Moore, F.; and Randall, Lori, 2007, Broad-scale response of landbird migration to the immediate effects of Hurricane Katrina.

Brady, L.M., Gray, Floyd, Wissler, C.A., and Guertin, D.P., 2001, Spatial variability of sediment erosion processes using GIS analysis within watersheds in a historically mined region, Patagonia Mountains, Arizona.

Brinda, J.C., Stark, L.R., Shevock, J.R., and Spence, J.R., 2007, An annotated checklist of the bryophytes of Nevada, with notes on collecting history in the state.

Cassidy, K.M., and Grue, C.E., 2000, The role of private and public lands in conservation of at-risk vertebrates in Washington State.

Chung, Y.J., and Winer, A.M., 1999, Field assessment of the California Gap Analysis program database for San Diego county.

Clark, J.D., Dobey, Steven, Masters, D.V., Scheick, B.K., Pelton, M.R., and Sunquist, M.E., 2005, American black bears and bee yard depredation at Okefenokee Swamp, Georgia.

Cogan, Christopher, 1997, California biodiversity project-Application of ecological data to biodiversity analysis.

Crist, M.R., Wilmer, Bo, 2002, Roadless areas - The missing link in conservation-An analysis of biodiversity and landscape connectivity in the northern Rockies.

Diefenbach, D.R., Riegner, C.F., and Hardisky, T.S., 2000, Harvest and reporting rates of game-farm ring-necked pheasants.

Doleman, W.H., 2005, Environmental constraints on forager mobility and the use of cultigens in southeastern Arizona and southern New Mexico.

Dymond, R.L., Regmi, B., Lohani, V.K., and Dietz, R., 2004, Interdisciplinary web-enabled spatial decision support system for watershed management.

Enwright, Nicholas, and Hudak, P.F., 2009, Spatial distribution of nitrate and related factors in the High Plains Aquifer, Texas.

Fertig, Walter, and Thurston, Robert, 2003, Modeling the potential distribution of BLM sensitive and USFWS threatened and endangered plant species in Wyoming.

Frescino, T.S., 1998, Development and validation of forest habitat models in the Uinta Mountains, Utah.

González, Grizelle, Gould, W.A., Hudak, A.T., and Hollingsworth, T.N., 2008, Decay of aspen

(Populus tremuloides Michx.) wood in moist and dry boreal, temperate, and tropical forest fragments.

Hanser, S.E., and Huntly, N.J., 2006, The biogeography of small mammals of fragmented sagebrushsteppe landscapes.

Hoffman, J.D., and Choate, J.R., 2008, Distribution and status of the yellow-faced pocket gopher in Kansas.
Citation Count 
Table 3. Citation count for publications using GAP data.-Continued

\section{Publication Reference}

Hoffman, J.D., Choate, J.R., and Channell, Rob, 2007, Effects of land use and soil texture on distributions of pocket gophers in Kansas.

Huang, Chengquan, Homer, Collin, and Yang, Limin, 2003, Regional forest land cover characterisation using medium spatial resolution satellite data.

Hudak, P.F., and Wachal, D.J., 2001, Oil production, agriculture and groundwater quality in the southeastern Gulf Coast Aquifer, Texas.

Hunter, L.M., and Brehm, J.M., 2004, A qualitative examination of value orientations toward wildlife and biodiversity by rural residents of the intermountain region.

Hychka, K.C., Wardrop, D.H., and Brooks, R.P., 2007, Enhancing a landscape assessment with intensive data - A case study in the Upper Juniata watershed.

Jantz, Patrick, and Goetz, Scott, 2008, Using widely available geospatial data sets to assess the influence of roads and buffers on habitat core areas and connectivity.

Karlik, J.F., Chung, Y.J., and Winer, A.M., 2003, Biogenic emission inventory development-Field assessment of the GAP vegetation database in California.

Kirkpatrick, Chris, Conway, C.J., Hughes, K.M., and Devos, J.C., 2007, Probability of detecting bandtailed pigeons during call-broadcast versus auditory surveys.

Kretser, H.E., Sullivan, P.J., and Knuth, B.A., 2008, Housing density as an indicator of spatial patterns of reported human-wildlife interactions in northern NewYork.

Landis, J.D.; Monzon, J.P.; Reilly, Michael; and Cogan, Chris, 1998, Development and pilot application of the California Urban and Biodiversity Analysis (CURBA) model.

Munson, A.B., and Delfino, J.J., 2007, Minimum wet-season flows and levels in southwest Florida rivers.

Neely, Betsy; Comer, Pat; Moritz, Cherie; Lammert, Mary; Rondeau, Renee; Pague, Chris; Bell, Gary; Copeland, Holly; Humke, John; Spackman, Susan; Schulz, Terri; Theobald, David; and Valutis, Laura, 2001, Southern Rocky Mountains-An ecoregional assessment and conservation blueprint.

Radwell, Andrea, 2000, Ecological integrity assessment of Ozark rivers to determine suitability for protective status.

Scarborough, James; Clinton, Nicolas; Pu, Ruilang; and Gong, Peng, 2001, Creating a statewide spatially and temporally allocated wildfire and prescribed burn emission inventory using consistent emission factors.

Theobald, D.M., Peterson, Nathan, and Romme, W.H., 2004, The Colorado vegetation model-Using national land cover data and ancillary spatial data to produce a high resolution, fine-classification map of Colorado.

Toschik, P.C., Christman, M.C., Rattner, B.A., and Ottinger, M.A., 2006, Evaluation of osprey habitat suitability and interaction with contaminant exposure.

Twilley, R.R.; Couvillion, B.R.; Hossain, Imtiaz; Kaiser, Carola; Owens, A.B.; Steyer, G.D.; and Visser, J.M., 2008, Coastal Louisiana ecosystem assessment and restoration program-The role of ecosystem forecasting in evaluating restoration planning in the Mississippi River Deltaic plain.

Wall, S.S., and Berry, C.R., Jr., 2006, The importance of multiscale habitat relations and biotic associations to the conservation of an endangered fish species, the Topeka shiner.
Citation Count

2

2

2

2

2

2

2

2

2

2

2

2

2

2

2 
Table 3. Citation count for publications using GAP data.-Continued

\section{Publication Reference}

Ward, Kathleen, and Juzwik, Jennifer, 2005, Change in the Minneapolis/St. Paul Metropolitan area oak forests from 1991 to 1998.

Ward, Kathleen; Ostry, Michael; Venette, Robert; Palik, Brian; Hansen, Mark; Hatfield, Mark, 2009, Assessment of black ash (Fraxinus nigra) decline in Minnesota.

Webb, E.B., Smith, L.M., Vrtiska, M.P., and Lagrange, T.G., 2010, Effects of local and landscape variables on wetland bird habitat use during migration through the Rainwater Basin.

Wright, R.G., and Scott, J.M., 1996, Evaluating the ecological suitability of lands for parks and protected areas using gap analysis databases.

Barker, C.M., Bolling, B.G., Moore, C.G., and Eisen, Lars, 2009, Relationship between distance from major larval habitats and abundance of adult mosquitoes in semiarid plains landscapes in Colorado.

Borak, J.S, and Strahler, A.H., 1996, Feature selection using decision trees-An application for the MODIS land cover algorithm.

Boykin, K.G., 2006, Multiscale analysis of habitat, vegetation change, and streamflow as ecological factors affecting population dynamics of Rana chiricahuensis.

Brenner, John; Paustian, Keith; Buhm, George; Cipra, Jan; Easter, Mark; Foulk, Robin, Killian, Kendrick; Moore, Ron; Schuler, Jill; Smith, Phil; and Williams, Steve, 2002, Quantifying the change in greenhouse gas emissions due to natural resource conservation practice application in Nebraska.

Briggs, N.A., and Sader, S.A., 2009, Tracking forest change and development using low-cost remote sensing imagery and GIS integration.

Briskey, J.A., Schulz, K.J., Mosesso, J.P., Horwitz, L.R., and Cunningham, C.G., 2007, Environmental planning issues and a conceptual global assessment of undiscovered nonfuel mineral resources.

Clinton, Nicholas; Scarborough, James; Tian, Yong; and Gong, Peng, 2003, A GIS based emissions estimation system for wildlife and prescribed burning.

Dietz, R.W., 2000, The use of GIS for integrated watershed analysis-Integration of environmental models with GIS in the Upper Roanoake River Watershed.

Dzialak, M.R., Carter, K.M., and Lacki, M.J., 2007, Perch site selection by reintroduced peregrine falcons Falco peregrinus.

Enquist, C.A.F., and Gori, D.F., 2008, Application of an expert system approach for assessing grassland status in the U.S.-Mexico borderlands-Implications for conservation and management.

Estrada-Peña, Agustín, 2009, Diluting the dilution effect-A spatial Lyme model provides evidence for the importance of habitat fragmentation with regard to the risk of infection.

Fisher, H., Butcher, J., Creager, C., and Saucerman, S., 2004, Application of a linked water quality response model for establishing nutrient criteria for the California oak and chaparral sub-ecoregion.

Fletcher, J.J., Eli, R.N., Strager, M.P., Sun, Qingyun, Churchill, J.B., Lamont, S.J., Galya, T.A., and Schaer, A.N., 2004, The watershed characterization and modeling system (WCMS)-Support tools for large watershed CHIA and NPDES analyses.

Greenwald, D.N., and Bradley, Curtis, 2008, Assessing protection for imperiled species of Nevada, U.S.A.-Are species slipping through the cracks of existing protections?
Citation Count

2

2

2

2

1

1

1

1

1

1

1

1

1

1

1

1

1

1 
Table 3. Citation count for publications using GAP data.-Continued

Publication Reference

Greenwood, D.L., 2006, Landscape analysis of tree mortality and pinyon-juniper woodland structure in the Great Basin.

Hagen, C.A., Pitman, J.C., Robel, R.J., Loughin, T.M., and Applegate, R.D., 2007, Niche partitioning by lesser prairie-chicken Tympanuchus pallidicinctus and ring-necked pheasant Phasianus colchicus in southwestern Kansas.

Hamazaki, Toshihide, Thompson, B.C., Locke, B.A., and Boykin, K.G., 2003, Analysis of ecological context for identifying vegetation and animal conservation planning foci-An example from the arid south-western USA.

Heaton, J.S., Kiester, A.R., and Meyers, S.M., 2006, LizLand-A geomorphic approach to lizard habitat modeling in the Mojave Desert.

Heller, J.A., Guertin, D.P., Miller, S.N., and Stone, J.J., 1999, GIS for watershed assessmentIntegrating spatial and tabular data to derive parameters for a hydrologic simulation model (ARDBSN).

Hubbard, Brett, and Serfass, Tom, 2004, Assessing the distribution of reintroduced populations of river otters in Pennsylvania (USA) — Development of a landscape-level approach.

Hunter, L.M., Beal, John, and Dickinson, Thomas, 2003, Integrating demographic and GAP analysis biodiversity data_-Useful insight?

Islas, C.G.R., 1996, A sensitivity test for species distribution models used for gap analysis in New Mexico.

Jochimsen, D.M., 2005, Factors influencing the road mortality of snakes on the Upper Snake River Plain, Idaho.

Kanda, L.L., Fuller, T.K., Sievert, P.R., and Friedland, K.D., 2005, Variation in winter microclimate and its potential influence on Virginia opossum (Didelphis virginiana) survival in Amherst, Massachusetts.

Kocovsky, P.M., Ross, R.M., Dropkin, D.S., and Campbell, J.M., 2008, Linking landscapes and habitat suitability scores for diadromous fish restoration in the Susquehanna River Basin.

Kostelnick, J.C., Peterson, D.L., Egbert, S.L., McNyset, K.M., and Cully, J.F., 2007, Ecological niche modeling of black-tailed prairie dog habitats in Kansas.

Kunert, Kelly, 2005, A GIS approach to habitat restoration site selection and prioritization in the New York-New Jersey Harbor Estuary.

Kunzmann, M.R., Rybak, Alexander, and Bennett, P.S., 2000, Yellow-billed cuckoo (Coccyzus americanus occidentalis) habitat identification using GPS and GIS based survey information.

LaBram, J.A., Peck, A.E., and Allen, C.R., 2007, Monitoring-based assessment of Gap-analysis models.

Lipow, S.R., Vance-Borland, Kenneth, St. Clair, J.B., Henderson, J.A., and McCain, Cindy, 2007, In situ gene conservation of six conifers in western Washington and Oregon.

Lopez, R.D., Nash, M.S., Heggem, D.T., and Ebert, D.W., 2008, Watershed vulnerability predictions for the Ozarks using landscape models.

Martin, D.J., White, G.C., and Pusateri, F.M., 2007, Occupancy rates by swift foxes (Vulpes velox) in eastern Colorado.

Martinuzzi, Sebastian, Vierling, L.A., Gould, W.A., Vierling, K.T., and Hudak, A.T., 2009, Incorporating remotely sensed tree canopy cover data into broad scale assessments of wildlife habitat distribution and conservation.
Citation Count 


\section{Table 3. Citation count for publications using GAP data.-Continued}

\section{Publication Reference}

Citation Count

Mawdsley, J.R., 2001a, Ecology, biogeography, and conservation of checkered beetles (Insecta:

Coleoptera: Cleridae) in southeastern Arizona-A geographic information system (GIS) study.

Moen, Ronald, Niemi, Gerald, and Burdett, C.L., 2008, Canada lynx in the Great Lakes region.

Monahan, W.B. and Koenig, W.D., 2007, Potential effects of Sudden Oak Death on the oak woodland bird community of coastal California.

Morrison, P.H, Karl, J.W., Harma, K.J., Swope, Lindsey, Allen, T.K., and Becwar, Pamela, 2000, Assessment of summer 2000 wildfires - Landscape history, current condition and ownership.

Murray, Michael, 2005, Our threatened timberlines-The plight of whitebark pine ecosystems.

O'Brien, C.S., Ockenfels, R.A., Bristow, K.D., and Boe, S.R., 2006, Habitat models-Desert bighorn sheep in the Silver Bell Mountains revisited.

Overton, C.T., Schmitz, R.A., and Casazza, M.L., 2006, Linking landscape characteristics to mineral site use by band-tailed pigeons in western Oregon-Coarse-filter conservation with fine-filter tuning.

Park, Sunyurp, and Egbert, S.L., 2008, Remote sensing-measured impacts of the conservation reserve program (CRP) on landscape structure in southwestern Kansas.

Potere, David; Woodcock, C.E.; Schneider, Annemarie; Ozdogan, Mutlu; and Baccini, Alessandro, 2007, Patterns in forest clearing along the Appalachian Trail corridor.

Randhir, Timothy, and Ekness, Paul, 2009, Urbanization effects on watershed habitat potential—A multivariate assessment of thresholds and interactions.

Regmi, Binaya, 2002, Web-enabled spatial decision support system for interdisciplinary watershed management.

Rice, M.B., Ballard, W.B., Fish, E.B., McIntyre, N.E., and Holdermann, D., 2008, The importance of accurate landuse/landcover maps for assessing habitat suitability for black bear (Ursus americanus) in the Trans-Pecos region of Texas.

Rink, G.R., and Cully, A.C., 2007, A checklist of the vascular flora of Yucca House National Monument and surrounding lands, Montezuma County, Colorado.

Rogers, P.C., Leffler, A.J., and Ryel, R.J., 2010, Landscape assessment of a stable aspen community in southern Utah, USA.

Sader, S.A., Jin, Suming, Metzler, J.W., and Hoppus, Michael, 2006, Exploratory analysis of forest harvest and regeneration pattern among multiple landowners.

Sherrouse, B.C., Clement, J.M., and Semmens, D.J., 2011, A GIS application for assessing, mapping, and quantifying the social values of ecosystem services.

Shilling, Fraser; Girvetz, Evan; Erichsen, Chris; Johnson, Brenda; and Nichols, Pete, 2002, A guide to wildlands conservation in the Greater Sierra Nevada bioregion.

1

1

1

(1)

1

1

1

1

Shinneman D.J. Watson, John, and Martin. W.W. 2000. The stat

Shinneman, D.J., Watson, John, and Martin, W.W., 2000, The state of the southern Rockies ecoregion-

A look at species imperilment, ecosystem protection, and a conservation opportunity.

Sridhar, Venkataramana, 2007, Evapotranspiration estimation and scaling effects over the Nebraska Sand Hills.

Steinitz, Carl; Anderson, Robert; Arias, Hector; Bassett, Scott; Flaxman, Michael; Goode, Tomas;

Maddock, Thomas, III; Mouat, David; Peiser, Richard; Shearer, Allan, 2005, Alternative futures for

landscapes in the Upper San Pedro River Basin of Arizona and Sonora. 
Table 3. Citation count for publications using GAP data.-Continued

Publication Reference

Citation Count

Taylor, K.J., 2003, Bayesian belief networks-A conceptual approach to assessing risk to habitat.

1

Theobald, D.M., and Hobbs, N.T., 1999, Calculating landscape fragmentation using a gradient-based approach.

Thorne, Jim, Camerson, Dick, and Jigour, Verna, 2002, A guide to wildlands conservation in the central coast region of California.

Toney, Chris; Rollins, Matthew; Short, Karen; Frescino, Tracey; Tymcio, Ronald; and Peterson, Birgit, 2005, Use of FIA plot data in the LANDFIRE project.

Tumbusch, M.L., and Plume, R.W., 2006, Hydrogeologic framework and ground-water levels in basinfill deposits of the Diamond Valley flow system, central Nevada.

1

Vogelmann, James; Zhu, Zhilang; Kost, Jay; Tolk, Brian; and Ohlen, Donald, 2006, Perspectives on LANDFIRE prototype project accuracy assessment.

Wang, Steven; Stiles, Thomas; Flynn, Trevor; Stahl, A.J.; Gutierrez, J.L.; Angelo, R.T.; and Frees, Lyle, 2009 , A modeling approach to water quality management of an agriculturally dominated watershed, Kansas, USA.

Warren, D.L., and Seifert, S.N., 2011, Environmental niche modeling in Maxent-The importance of model complexity and the performance of model selection criteria.

Webb, W.C., Boarman, W.I., and Rotenberry, J.T., 2009, Movements of juvenile common ravens in an arid landscape.

Winer, A.M., and Karlik, J.F., 2001, Development and validation of databases for modeling biogenic hydrocarbon emissions in California's airsheds.

Wooten, George, 2002, Shrub-steppe conservation prioritization in Washington state.

Zasada, Michal, Cieszewski, C.J., and Lowe, R.C., 2003, Impact of stream management zones and road beautifying buffers on long-term fiber supply in Georgia.

Zicus, M.C., Rave, D.P., Fieberg, J.R., Guidice, J.H., and Wright, R.G., 2008, Distribution and abundance of Minnesota breeding ring-necked ducks Aythya collaris.

Publications using GAP data have been cited, some of them extensively, in other publications. This suggests that when publications cite GAP data there is a potential secondary diffusion effect of information regarding GAP data. Those who are not otherwise familiar with GAP data may be introduced to GAP through these publications.

We cross-referenced the publications and their respective citation counts with the datasets used in the publications. We made this comparison to determine if certain datasets were used in publications that were cited more frequently. In table 4, we provided a list of the datasets, the number of publications using each dataset, and the number of publications that cite the publications using the datasets. For example, the Arkansas land-cover dataset was used in 13 publications and those 13 publications were cited in 241 other publications. 
Table 4. Datasets, number of publications using each dataset, and number of citations.

\begin{tabular}{|c|c|c|c|}
\hline & Data Set & $\begin{array}{c}\text { Number of } \\
\text { Publications } \\
\text { Using }\end{array}$ & $\begin{array}{c}\text { Number of } \\
\text { Publications } \\
\text { Citing }\end{array}$ \\
\hline \multicolumn{4}{|l|}{ Alabama } \\
\hline & Land Cover & 3 & \\
\hline & Predicted Species Distribution & 1 & \\
\hline & Stewardship & 1 & \\
\hline \multicolumn{4}{|l|}{ Arizona } \\
\hline & Analysis & 1 & 1 \\
\hline & Land Cover & 35 & 442 \\
\hline & Predicted Species Distribution & 6 & 33 \\
\hline & Stewardship & 7 & 43 \\
\hline \multicolumn{4}{|l|}{ Arkansas } \\
\hline & Land Cover & 13 & 241 \\
\hline & Predicted Species Distribution & 1 & \\
\hline & Stewardship & 4 & 192 \\
\hline \multicolumn{4}{|l|}{ California } \\
\hline & Analysis & 1 & 3 \\
\hline & Land Cover & 93 & 927 \\
\hline & Predicted Species Distribution & 11 & 223 \\
\hline & Stewardship & 21 & 380 \\
\hline \multicolumn{4}{|l|}{ Colorado } \\
\hline & Land Cover & 22 & 422 \\
\hline & Predicted Species Distribution & 3 & 31 \\
\hline & Stewardship & 5 & 83 \\
\hline \multicolumn{4}{|c|}{ Connecticut } \\
\hline & Land Cover & 1 & \\
\hline & Stewardship & 1 & 2 \\
\hline \multicolumn{4}{|l|}{ Delaware } \\
\hline & Land Cover & 4 & 10 \\
\hline & Predicted Species Distribution & 1 & 3 \\
\hline & Stewardship & 3 & 5 \\
\hline \multicolumn{4}{|l|}{ Florida } \\
\hline & Land Cover & 26 & 286 \\
\hline & Predicted Species Distribution & 2 & \\
\hline & Stewardship & 2 & \\
\hline \multicolumn{4}{|l|}{ Georgia } \\
\hline & Land Cover & 12 & 13 \\
\hline & Predicted Species Distribution & 3 & \\
\hline & Stewardship & 2 & \\
\hline \multicolumn{4}{|l|}{ Hawaii } \\
\hline & Land Cover & 3 & \\
\hline & Stewardship & 1 & 4 \\
\hline
\end{tabular}


Table 4. Datasets, number of publications using each dataset, and number of citations.-Continued

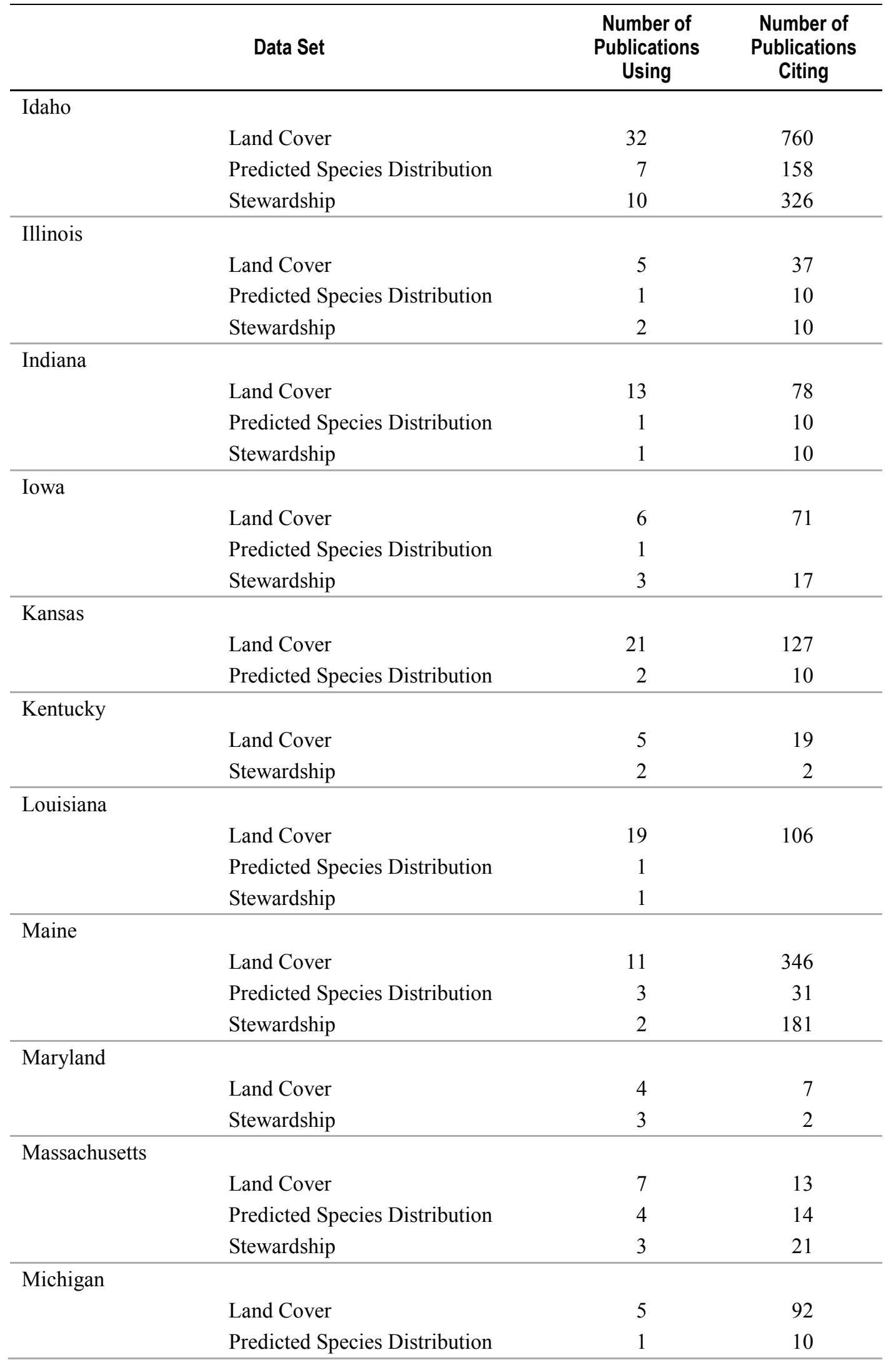


Table 4. Datasets, number of publications using each dataset, and number of citations.-Continued

\begin{tabular}{|c|c|c|c|}
\hline & Data Set & $\begin{array}{c}\text { Number of } \\
\text { Publications } \\
\text { Using }\end{array}$ & $\begin{array}{c}\text { Number of } \\
\text { Publications } \\
\text { Citing }\end{array}$ \\
\hline \multicolumn{4}{|l|}{ Minnesota } \\
\hline & Land Cover & 19 & 44 \\
\hline & Predicted Species Distribution & 1 & 1 \\
\hline & Stewardship & 2 & \\
\hline \multicolumn{4}{|l|}{ Mississippi } \\
\hline & Land Cover & 7 & 22 \\
\hline & Predicted Species Distribution & 2 & \\
\hline & Stewardship & 1 & \\
\hline \multicolumn{4}{|l|}{ Missouri } \\
\hline & Land Cover & 3 & \\
\hline & Predicted Species Distribution & 1 & 4 \\
\hline & Stewardship & 2 & 27 \\
\hline \multicolumn{4}{|l|}{ Montana } \\
\hline & Land Cover & 16 & 376 \\
\hline & Predicted Species Distribution & 4 & 109 \\
\hline & Stewardship & 8 & 311 \\
\hline \multicolumn{4}{|l|}{ Nebraska } \\
\hline & Land Cover & 8 & 19 \\
\hline & Predicted Species Distribution & 1 & \\
\hline & Stewardship & 1 & \\
\hline \multicolumn{4}{|l|}{ Nevada } \\
\hline & Land Cover & 16 & 70 \\
\hline & Predicted Species Distribution & 1 & \\
\hline & Stewardship & 2 & 13 \\
\hline \multicolumn{4}{|c|}{ New Hampshire } \\
\hline & Land Cover & 1 & \\
\hline & Stewardship & 2 & 2 \\
\hline \multicolumn{4}{|l|}{ New Jersey } \\
\hline & Land Cover & 4 & 8 \\
\hline & Stewardship & 4 & 3 \\
\hline \multicolumn{4}{|l|}{ New Mexico } \\
\hline & Land Cover & 30 & 549 \\
\hline & Predicted Species Distribution & 7 & 24 \\
\hline & Stewardship & 10 & 274 \\
\hline \multicolumn{4}{|l|}{ New York } \\
\hline & Land Cover & 8 & 43 \\
\hline & Predicted Species Distribution & 2 & 1 \\
\hline & Stewardship & 5 & 5 \\
\hline
\end{tabular}


Table 4. Datasets, number of publications using each dataset, and number of citations.-Continued

\begin{tabular}{|c|c|c|c|}
\hline & Data Set & $\begin{array}{l}\text { Number of } \\
\text { Publications } \\
\text { Using }\end{array}$ & $\begin{array}{c}\text { Number of } \\
\text { Publications } \\
\text { Citing }\end{array}$ \\
\hline \multicolumn{4}{|l|}{ North Carolina } \\
\hline & Land Cover & 2 & \\
\hline & Predicted Species Distribution & 2 & \\
\hline & Stewardship & 3 & 2 \\
\hline \multicolumn{4}{|l|}{ North Dakota } \\
\hline & Land Cover & 2 & \\
\hline & Stewardship & 1 & \\
\hline \multicolumn{4}{|l|}{ Ohio } \\
\hline & Land Cover & 1 & \\
\hline \multicolumn{4}{|l|}{ Oklahoma } \\
\hline & Land Cover & 9 & 19 \\
\hline & Stewardship & 1 & 33 \\
\hline \multicolumn{4}{|l|}{ Oregon } \\
\hline & Analysis & 1 & 5 \\
\hline & Land Cover & 29 & 250 \\
\hline & Predicted Species Distribution & 3 & 95 \\
\hline & Stewardship & 7 & 49 \\
\hline \multicolumn{4}{|l|}{ Pennsylvania } \\
\hline & Land Cover & 13 & 112 \\
\hline & Predicted Species Distribution & 2 & 3 \\
\hline & Stewardship & 3 & 5 \\
\hline \multicolumn{4}{|l|}{ Puerto Rico } \\
\hline & Land Cover & 4 & 9 \\
\hline & Predicted Species Distribution & 1 & \\
\hline \multicolumn{4}{|l|}{ Rhode Island } \\
\hline & Land Cover & 1 & \\
\hline & Stewardship & 1 & 2 \\
\hline \multicolumn{4}{|l|}{ South Carolina } \\
\hline & Land Cover & 7 & 10 \\
\hline & Predicted Species Distribution & 3 & 10 \\
\hline & Stewardship & 2 & \\
\hline \multicolumn{4}{|l|}{ South Dakota } \\
\hline & Land Cover & 7 & 106 \\
\hline & Predicted Species Distribution & 1 & \\
\hline \multicolumn{4}{|l|}{ Tennessee } \\
\hline & Land Cover & 2 & 18 \\
\hline & Stewardship & 1 & 2 \\
\hline
\end{tabular}


Table 4. Datasets, number of publications using each dataset, and number of citations.-Continued

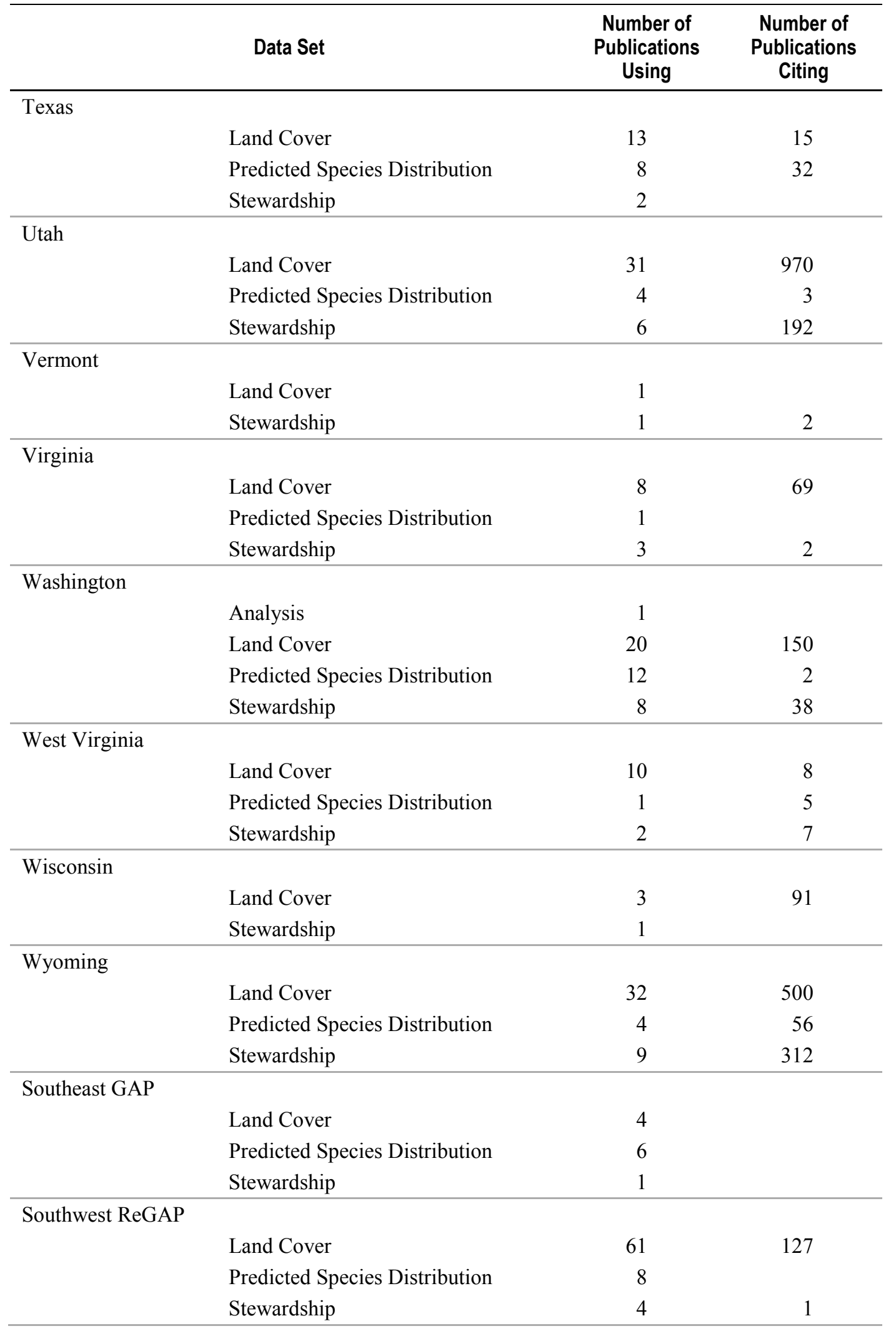


Table 4. Datasets, number of publications using each dataset, and number of citations.-Continued

\begin{tabular}{lccc}
\hline & Data Set & $\begin{array}{c}\text { Number of } \\
\text { Publications } \\
\text { Using }\end{array}$ & $\begin{array}{c}\text { Number of } \\
\text { Publications } \\
\text { Citing }\end{array}$ \\
\hline Northwest GAP & Land Cover & 2 & 5 \\
\hline National & Stewardship & 3 & 5 \\
\hline
\end{tabular}

There is a strong correlational relationship between the number of publications in which a dataset was used and the number of citations: $r=0.75, n=105$. Generally, a higher number of publications using a dataset is positively related to the number of citations to the publications using that dataset. However, this is not a perfect relationship. Because the California land-cover dataset was used most frequently in publications, it is reasonable to expect that this dataset would be associated with the most citations. The 93 publications using California land cover were cited in a total of 927 publications. Utah land cover was used in fewer publications - this dataset was used in 31 publications - yet publications using this data were cited in a total of 970 publications. Utah was one of the first states to complete a GAP project which may contribute to the number of citations attributed to publications that utilized Utah GAP data (Jocelyn Aycrigg, GAP, oral commun., 2010).

It is difficult to determine from available evidence why some publications are cited more than others. Less cited publications may appear in journal outlets that are of regional interest with limited circulation. They may receive less exposure and therefore are cited less frequently. It may be that the characteristics of some datasets make them more useful. It is clear that some datasets are not benefitting as much as others from a secondary diffusion via use in the published literature.

Notably, publications using the regional and national GAP datasets lack citations. The

SWReGAP land-cover dataset is the only one that frequently appeared in publication citations. The lack of citations for publications using regional datasets is not surprising given that these are newer datasets. It is likely that the publications using these datasets are more recent and therefore have not been available long enough to accumulate a citation history.

In a figure paralleling figure 6 which depicts the number of times each dataset was used, figure 9 depicts the number of citations associated with publications using each dataset. Datasets were not included in this figure if there were no citations associated with any publication using that dataset. The number of citations are provided in the figure when there were more than 100 citations. 


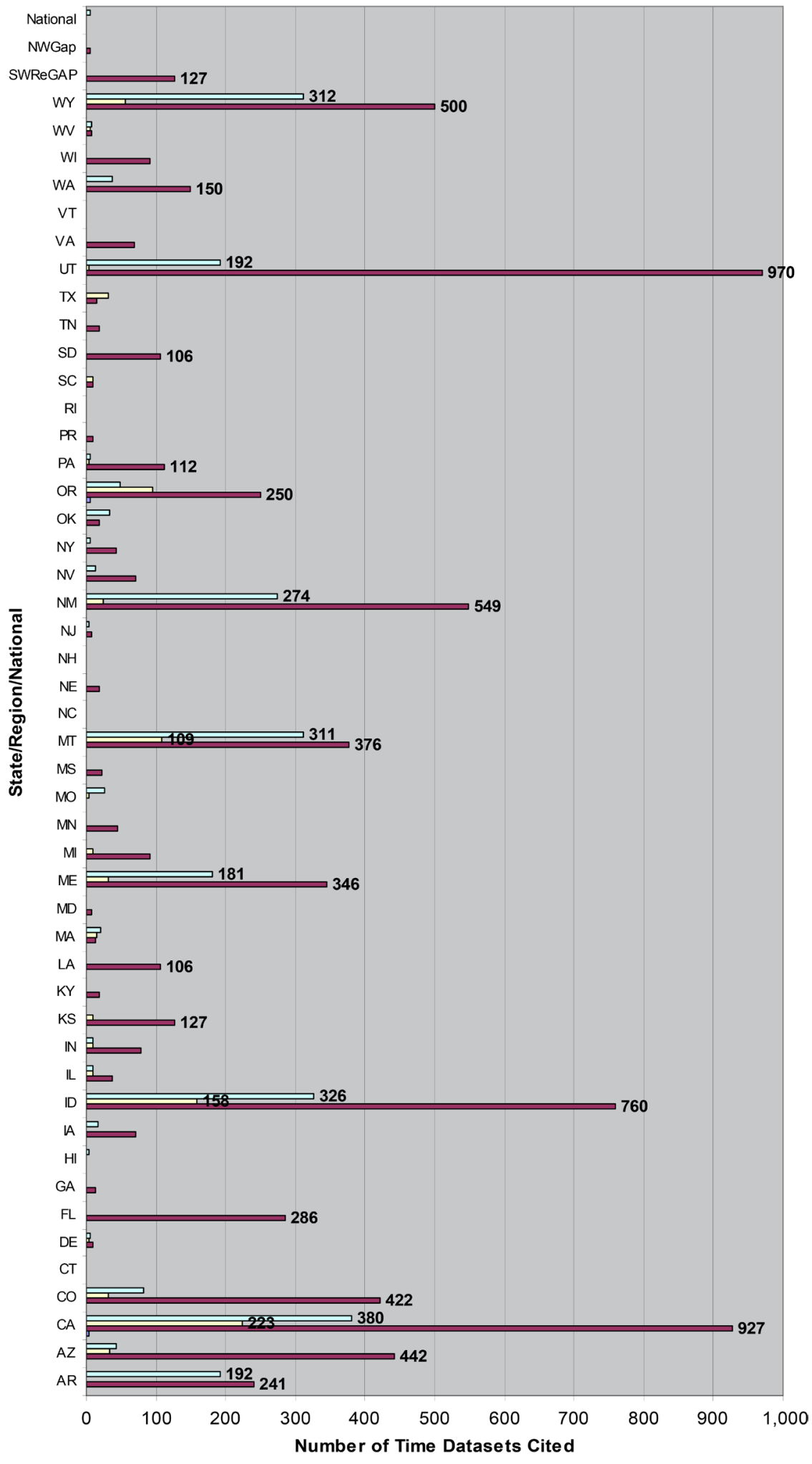

$\square$ Analysis $\square$ Landcover $\square$ Predicted Species $\square$ Stewardship

Figure 9. Number of citations associated with publications using each dataset. 


\section{Summary}

The bibliometric analysis of published literature citing use of GAP data was limited in focus. We did not compare the research resulting from use of GAP data with research using other similar datasets. When bibliometric analysis is used for evaluation purposes, comparisons are often made among programs (Davis and Royle, 1996), disciplines (Mullins, 1987), or geographic entities such as states (Shapira and others, 2003) or countries (Garg, 2003). Our analysis lacked these comparisons. However, this bibliometric analysis was only a small part of the overall program evaluation and served the purpose of determining an added benefit of GAP — research productivity. The 342 journal articles appeared in 161 journals associated with 34 disciplines. This suggests that GAP data are used in many disciplines for purposes beyond conservation of biodiversity.

We identified the journal impact factors for the published journal articles using GAP data. Publications using GAP data appeared in a variety of journals with a wide range of impact factors. In bibliometric research, impact factors are used to indicate the impact of the articles included in the journal (Davis and Royle, 1996; Seglen, 1997) and indicate the prestige of the journal (Davis and Royle, 1996). Forty percent of the journal articles included in the publications using GAP data were published in journals that are considered top journals within their respective disciplines based on the impact factors. Smaller proportions of journal articles were published in the second and third quartiles of impact rank, 28 percent and 23 percent respectively. Many of the journals in the third quartile were more likely to appeal to a regional rather than national audience which may have affected the impact factors.

Citation rates tend to be skewed (Pendlebury, 2009; Seglen, 1997) with a small number of articles being cited frequently and a large number of articles being cited infrequently. This pattern was evident in the citations to publications using GAP data. Older publications tend to have higher citation counts. Yet, the publication using GAP data that was most frequently cited was published in 2004. The publications that are among the most frequently cited are a mix of early (mid-1990s) publications using GAP data and those published in the early 2000s.

The datasets used in the most publications are not necessarily those in the publications with the most citations. Citation behavior is complex. Based on the available information, it is difficult to determine why some datasets were used more frequently in publications or why publications using particular datasets were cited more frequently than others. The frequency data does suggest that landcover data is used more frequently than the other types of datasets and that publications using some land-cover datasets are cited more frequently than those using other datasets.

The diversity in journals publishing articles using GAP data, the range of journal impact factors associated with these publication outlets, and the variation in citation rates for these publications suggest variation in exposure to and reaction to the different datasets. This has specific implications for the survey of GAP users. The survey must include questions to determine the dataset each survey respondent is most familiar with and the questions must be specific to GAP datasets. This requires an adaptive survey. For example, we included questions early in the survey that identify which dataset the respondent has used and that facilitate directing that respondent to questions particular to that dataset.

\section{Discussion}

We located 646 publications that clearly stated a use of GAP data. One early concern in the search for published literature using GAP was the possibility that people were using GAP but not correctly identifying GAP as the source of their data. There may be some people who are using the data and not attributing it to GAP, but evidence suggests that people do reference the data they use to GAP. 
There were a few publications in which the authors noted that they used GAP data in their acknowledgments section but did not specifically identify any GAP dataset in the text of the publication. Other than correct attribution to a source, the diffusion of information regarding GAP datasets and GAP itself is an important reason for GAP data to be identified when it is used in a publication. Publishing the use of GAP data is one way to publicize the data as a resource. Impact of a program as determined by publication and citation counts can be affected by the visibility of the program (Martin and Irvine, 1983). A circular pattern exists. The impact of a program is affected by publication based on the program's datasets; more publications are generally interpreted as a greater impact. When more publications are available, there is greater likelihood that others will be exposed to information regarding the program and the datasets it produces and additional use of the program data will result. Increased use of the data, particularly when publications are produced, leads to a higher impact as measured by publication and citation counts.

Many publications used GAP data. These publications were produced by many authors — not a limited group of authors. This suggests that knowledge about GAP and the datasets it produces is not restricted to a particular group of individuals. The publications were mostly journal articles but also included conference presentations, dissertations and theses, reports, and book chapters. The prominence of journal articles may be an artifact of the reliance on databases in the search method used to find publications using GAP data. The publications in journals were not limited to a select list of titles. The journals in which these articles were published represented a broad range of topics and disciplines. Due to the nature of the search method, the results may over-represent academic research rather than use of GAP data for on-the-ground conservation decisions.

As anticipated, the datasets cited in the published articles were primarily from state and not regional or national projects. This does not mean that the regional and national datasets are less useful or that they will have less impact. It simply means that they may be too recent to have accumulated a publication and citation history. Continued use of state datasets suggests that, contrary to conventional wisdom that older data is not as good, older GAP data is still useful. Even the publications produced in the first six months of 2010 used state datasets; this suggests that GAP data has a long "shelf life." Older data is necessary for studies of landscape and climate change. Ramsey and others (2009) used GAP data in a study of the recovery after Hurricane Katrina.

Based on the sample of publications using GAP data that were included in this study, land-cover data appears to be used more than the other types of data produced by GAP. When we looked at number of publications using each type of data, land-cover data was used in 73 percent of the publications. The summary of the number of times each dataset was used indicated that the California land-cover dataset was used most frequently. In the analysis of citation counts associated with datasets, the Utah landcover dataset was used in the publications that received the most citations in other publications.

We searched the text of the publications for statements regarding GAP data. The following six themes emerged from the statements: description of data, how data were used, critiques, comparisons, commentary, and reference to GAP data. We described each of these themes and provided examples. The theme including statements regarding how GAP data were used yielded two points of particular interest. First, some of the statements described how GAP data were transformed by adding data, removing data, or otherwise altering existing GAP data. This suggests that some level of GIS expertise is necessary to use GAP data. Second, GAP data were used in a wide array of applications. The evaluative statements in the critique, comparisons, and commentary themes were a combination of favorable and unfavorable statements regarding GAP data. The mixed tenor of these comments suggests that the issues raised in some of the statements may be specific to particular uses of GAP data and not 
the data. An issue such as the datedness of the data may be problematic in some circumstances but beneficial in others.

The bibliometric analysis indicates that journal articles using GAP data appear in journals affiliated with multiple disciplines and at all levels of impact as defined by the journal impact factors. The set of publications used in this study were cited in a combined number of 2,295 other publications. People who read publications in which the authors used GAP data and specifically identified the data as from GAP are exposed to GAP data. It may be the reader's initial introduction to GAP. Other readers who are familiar with GAP and the data it provides may develop a greater understanding of GAP data and potential uses of these datasets. There is evidence that publications using GAP data have served as a means to diffuse this information.

Citation counts indicate that publications using GAP data have been cited in other publications at varied rates. Some publications have been cited very frequently. For example, the Homer and others (2004) article describing the development of a national land-cover database has - as of the date the citation search was conducted in August 2011 - been cited in over 250 other publications.

The results of this published literature study point to diversity in the uses of GAP data. The publications that used GAP data appeared in a variety of types of publications although primarily in journals. The journals were numerous and from a wide variety of disciplines. Even though most of the datasets used were land-cover data, many specific datasets were used in the publications. The text of the publications indicated that GAP data were used for different purposes and in different ways. The publications appeared in journals at all levels of impact as defined by journal impact factors and withindiscipline quartile ranks. There was diversity in the publications, datasets, comments, and citation patterns. The primary implication of this diversity for the development of the survey is that the survey questions needed to be tailored to specific datasets. To achieve this tailoring, particular attention is necessary in the construction of the survey. The analysis of adaptive survey data is more complicated than for a simpler survey.

In summary, the implications for the survey of GAP users include developing specific questions based on issues identified in the qualitative analysis of statements made in the publications, and tailoring questions so that they are specific to datasets. The authors who published these articles have clearly used GAP data and will be included in the survey sample.

\section{Acknowledgments}

This project was commissioned by the Gap Analysis Program of the U.S. Geological Survey. We are indebted to Alison Level, Reference Librarian and Associate Professor of Instruction and Research Services at Colorado State University, who assisted us with planning our literature search. Two external reviewers provided thoughtful and detailed comments on our report. We express our gratitude to Dr. Wayne E. Thogmartin, Quantitative Ecologist at the Upper Midwest Environmental Sciences Center, USGS, and Dr. David Alan Weinstein, Senior Research Associate in the Department of Natural Resources at Cornell University.

\section{List of References}

This list of references includes the references cited in text; the list of publications that cited GAP data, some of which were cited in text, marked with an asterisk $(*)$; and the secondary references that occurred within the quotations we used from the publications that cited GAP data, marked with two asterisks $(* *)$. These secondary citations are provided only as a courtesy to the reader. 
*Ackerman, Drew, and Schiff, Kenneth, 2003, Modeling storm water mass emissions to the southern California bight: Journal of Environmental Engineering, v. 129, no. 4., p. 308-317.

*Acosta, Jessica, Brooks, R.P., and Gould, W.A., 2007, Geographic analysis of habitat change for endemic animal species of Puerto Rico [abs.]: Association of American Geographers 2007 Annual Meeting Abstracts, San Francisco, Calif., p. 6.

*Adjemian, J.C.Z., Girvetz, E.H., Beckett, Laurel, and Foley, J.E., 2006, Analysis of genetic algorithm for rule-set production (GARP) modeling approach for predicting distributions of fleas implicated as vectors of plague, Yersinia pestis, in California: Journal of Medical Entomology, v. 43, no. 1, p. $93-103$.

*Alfieri, J.G.; Niyogi, Dev; LeMone, M.A.; Chen, Fei; and Fall, Souleymane, 2007, A simple reclassification method for correcting uncertainty in land use/land cover data sets used with land surface models: Pure and Applied Geophysics, v. 164, p. 1789-1809.

*Allen, C.R., Johnson, A.R., and Parris, Leslie, 2006, A framework for spatial risk assessmentsPotential impacts of nonindigenous invasive species on native species: Ecology and Society, v. 11, no. 1, art. 39, accessed February 3, 2011, at http://www.ecologyandsociety.org/vol11/iss 1/art39/.

*Allen, K.E., Bradley, R.D., Monk, R.R., Knyazhnitskiy, O.V., Parker, N.C., Schmidly, D.J., and Baker, R.J., 2001, Employment of geographic information systems for determining the accuracy of museum voucher specimen data: Museum of Texas Tech University Occasional Papers, no. 210, 7 p., accessed March 5, 2011, at http://www.nsrl.ttu.edu/publications/opapers/ops/op210.pdf.

*Ames, Jenna, 2006, Identifying moose habitat in Cache and Rich counties: Logan, Utah, unpublished manuscript, 12 p. accessed March 3, 2011, at http://www.gis.usu.edu/ doug/RS5750/PastProj/FA2005/JennaAmes_FinalProject.pdf.

*Arizona Water Atlas, n.d., Southeastern Arizona Planning Area-Section 3.12 San Rafael Basin: Phoenix, Arizona Department of Water Resources, v. 3, accessed March 29, 2011, at http://www.adwr.state.az.us/AzDWR/StatewidePlanning/WaterAtlas/SEArizona/documents/volume_3_ SRF final.pdf.

*Ashley, P.R., and Stovall, S.H., 2004, Draft Methow subbasin wildlife assessment and inventory: Portland, Oreg., unpublished manuscript, 82 p., accessed March 8, 2011, at http://www.nwcouncil.org/fw/subbasinplanning/methow/Plan/ e-Appendix\%20L\%20Wildlife\%20Assessment/MethowSubbasinAssessment.pdf.

*Ashley, Paul, and Stovall, S.H., 2004, Draft Okanogan subbasin wildlife assessment and inventory: Portland, Oreg., unpublished manuscript, 86 p., accessed March 8, 2011, at http://www.nwcouncil.org/fw/subbasinplanning/okanogan/plan/ e-Appendix\%20M\%20Wildlife\%20Assessment/OkanoganSubbasinAssessment.pdf.

*Ashley, P.R., and Stovall, S.H., 2004, Southeast Washington subbasin planning ecoregion wildlife assessment: Portland, Oreg., unpublished manuscript, 216 p., accessed March 7, 2011, at http://www.nwcouncil.org/fw/subbasinplanning/WallaWalla/plan/AppF_WildilfeAssessment_sm_ Part1.pdf.

*Assal, T.J., and Lockwood, J.A., 2007, Utilizing remote sensing and GIS to detect prairie dog colonies: Rangeland Ecology \& Management, v. 60, no. 1, p. 45-53.

*Atamian, M.T., Sedinger, J.S., Heaton, J.S., and Blomberg, E.J., 2010, Landscape-level assessment of brood rearing habitat for greater sage-grouse in Nevada: Journal of Wildlife Management, v. 74, no. $7,1533-1543$.

*Aunan, Tim; Palik, Brian; and Verry, Sandy, 2005, A GIS approach for delineating variable-width riparian buffers based on hydrological function: Minnesota Forest Resources Council, Research 
Report 0105, accessed February 24, 2011, at http://www.frc.state.mn.us/documents/council/

Variable-Width_Riparian_Buffers_2005-01-26_Report.pdf.

*Bajema, R.A., DeVault, T.L., Scott, P.E., and Lima, S.L., 2001, Reclaimed coal mine grasslands and their significance for Henslow's Sparrows in the American Midwest: Auk, v. 118, no. 2, p. $422-431$.

*Bajema, R.A., and Lima, S.L., 2001, Landscape-level analyses of Henslow's Sparrow (Ammodramus henslowii) abundance in reclaimed coal mine grasslands: American Midland Naturalist, v. 145, no. 2, p. 288-298.

*Bak, J.M., Boykin, K.G., Daniel, D.L., and Thompson, B.C., 2000, The effects of black-tailed prairie $\operatorname{dog}$ (Cynomys ludovicianus) colonies on the distribution of wintering ferruginous hawks (Buteo regalis): Las Cruces, New Mexico State University, unpublished manuscript, 30 p., accessed March 3, 2011, at http://fws-case-12.nmsu.edu/kboykin/publications/Bak2000Thesis.pdf.

*Baker, N.M., 2008, Identifying focal wildlife conservation areas on private lands in North Carolina: Durham, N.C., Duke University, Master's thesis, 29 p., accessed March 3, 2011, at http://dukespace.lib.duke.edu/dspace/bitstream/handle/10161/501/MP_nmb10_a_200805.pdf? sequence $=1$.

*Bare, T.J., 2008, A change detection analysis of agricultural land use from the 1970's to 2001 in Dane County, Wisconsin and the relationship to urban growth: Winona, Saint Mary's University of Minnesota, 12 p., accessed January 11, 2011 at http://www.gis.smumn.edu/GradProjects/BareT.pdf.

*Barker, C.M., Bolling, B.G., Moore, C.G., and Eisen, Lars, 2009, Relationship between distance from major larval habitats and abundance of adult mosquitoes in semiarid plains landscapes in Colorado: Journal of Medical Entomology, v. 46, no. 6, p. 1290-1298.

*Barrow, Wylie, Jr.; Buler, J.; Couvillion, Brady; Diehl, Robb; Faulkner, Stephen; Moore, F.; and Randall, Lori, 2007, Broad-scale response of landbird migration to the immediate effects of Hurricane Katrina, in Science and the Storms - The USGS response to the Hurricanes of 2005: U.S. Geological Survey Circular 1306, p. 131-136, accessed March 21, 2011, at http://pubs.usgs.gov/circ/1306/pdf/c1306_ch6_b.pdf

*Barten, P.K., de la Crétaz, A.L., and Zhang, Yanli, 2002, Land conservation, restoration, and stormwater management priorities for the Pretty Boy Reservoir Watershed, Maryland: University of Massachusetts-Amherst, Department of Natural Resources Conservation, 20 p., accessed March 3, 2011, at http://www.tpl.org/content_documents/Prettyboy_Initial_Report.pdf.

*Bassett, S.D., and Edwards, T.C., Jr., 2003, Effect of different sampling schemes on the spatial placement of conservation reserves in Utah, USA: Biological Conservation, v. 113, no. 1, p. 141-151.

*Bauer, M.E., Loeffelholz, Brian, and Wilson, Bruce, 2005, Estimation, mapping and change analysis of impervious surface area by Landsat remote sensing, in ASPRS Pecora 16 Conference, Sioux Falls, S. Dak., 2005, Proceedings: Bethesda, Md., American Society for Photogrammetry and Remote Sensing (ASPRS), 9 p., accessed February 18, 2011, at http://rsl.gis.umn.edu/Documents/Pecora\%20Conference\%20Impervious\%20paper.pdf.

*Bauer, M.E., Loeffelholz, B.C., and Wilson, Bruce, 2007, Estimating and mapping impervious surface area by regression analysis of Landsat imagery, in, Weng, Qihao, ed., Remote sensing of impervious surfaces: Boca Raton, Fla., CRC Press, preprint chapter, 20 p., accessed March 16, 2011, at http://rsgl.gis.umn.edu/Documents/Mapping\%20Impervious\%20Surface\%20Area\%20--\%20book\% 20chapter.pdf.

*Beal, J.G., 2000, Human population and biodiversity in Utah-Adding a demographic component to the Utah Gap Analysis Program analysis: Logan, Utah State University, Master's thesis, 155 p.

*Beard, K.H., Hengartner, Nicolas, and Skelly, D.K., 1999, Effectiveness of predicting breeding bird distributions using probabilistic models: Conservation Biology, v. 13, no. 5, p. 1108-1116. 
*Beardsley, Karen; Roth, Nathaniel; and McCoy, M.C., 2007, Impacts of different growth scenarios in the San Joaquin valley of California, in Irwin, C.L., Nelson, D., and McDermott, K.P., eds., Proceedings of the 2007 International Conference on Ecology and Transportation: Raleigh, North Carolina State University, Center for Transportation and the Environment, p. 360-366, accessed March 2, 2011, at http://escholarship.org/uc/item/1f5272f2.

*Beauvais, G.P., Thurston, Robert, and Keinath, Douglas, 2003, Predictive range maps for 15 species of management concern in the Rocky Mountain region of the USDA Forest Service: Laramie, University of Wyoming, 12 p., accessed January 15, 2011, at http://www.uwyo.edu/wynddsupport/docs/Reports/WYNDDReports/U03BEA07WYUS.pdf.

*Beck, J.L., Reese, K.P., Connelly, J.W., and Lucia, M.B., 2006, Movements and survival of juvenile greater sage-grouse in southeastern Idaho: Wildlife Society Bulletin, v. 34, no. 4, p. 1070-1078.

*Beckage, Brian; Comiskey, Jane; and Duke-Sylvester, Scott, 2005, Response to Maehr and LarkinNatural fire regimes in southern Florida: Natural Areas Journal, v. 25, no. 1, p. 6-8.

*BenDor, Todd; Westervelt, James; Aurambout, J.P., and Meyer, William, 2009, Simulating population variation and movement within fragmented landscapes-An application to the gopher tortoise (Gopherus polyphemus): Ecological Modelling, v. 220, no. 6, p. 867-878.

*Benjamin, M.T.; Winer, A.M.; Karlik, John; Campbell, Skip; Jackson, Bruce; and Lashgari, Ash, 1998, Assembling a biogenic hydrocarbon emissions inventory for the SCOS97-NARSTO modeling domain, in 91st Annual Meeting of Air and Waste Management Association, San Diego, Calif., Paper No. 98-A621, accessed June 20, 2010, at http://arb.ca.gov/research/scos/awma_98/bhc/awma4.doc.

*Bennett, P.S., and Kunzmann, Michael, 1998, Vegetation classification field techniques verses the Arizona GAP Program vegetation map, in Cross border waters-Fragile treasures for the 21st century, Ninth U.S./Mexico Border States Conference on Recreation, Parks, and Wildlife, Tucson, Ariz., June 3-6, 1998, Proceedings: Fort Collins, Colo., U.S. Department of Agriculture Forest Service, Rocky Mountain Research Station, RMRS-P-5, p. 119-128.

*Biggs, Brian; Olsen, Eric; Patraw, Kimberly; Van Niel, Tom; Falconer, Allan; and Ramsey, R.D., 1996, Removing Dilbert from GIS - Creating a user-friendly management tool for military installations, in 1996 ESRI International User Conference, Palm Springs, Calif., Proceedings: Redlands, Calif., Environmental Systems Research Institute (ESRI), paper 26, accessed January 20, 2011, at http:proceedings.esri.com/llibrary/userconf/proc96/TO50/PAP026/P26.HTM.

*Bond, J.E., Beamer, D.A., Lamb, T., and Hedin, M., 2006, Combining genetic and geospatial analyses to infer population extinction in mygalomorph spiders endemic to the Los Angeles region: Animal Conservation, v. 9, p. 145-157.

*Boone, J.D., McGwire, K.C., Otteson, E.W., DeBaca, R.S., Kuhn, E.A., Villard, Pascal, Brussard, P.F., and St. Jeor, S.C., 2000, Remote sensing and geographic information systems - Charting sin nombre virus infections in deer mice: Emerging Infectious Diseases, v. 6, no. 3, p. 248-258.

*Borak, J.S, and Strahler, A.H., 1996, Feature selection using decision trees-An application for the MODIS land cover algorithm in 1996 International Geoscience and Remote Sensing Symposium (IGARRS), Lincoln, Neb., May 27-31, 1996: IGARRS, vol. 1, p.243-245.

*Borak, J.S., and Strahler, A.H., 1999, Feature selection and land cover classification of a MODIS-like data set for a semiarid environment: International Journal of Remote Sensing, v. 20, no. 5, p. 919-938.

Bornmann, Lutz, and Daniel, H.D., 2008, What do citation counts measure? A review of studies on citing behavior: Journal of Documentation, v. 64, no. 1, p. 45-80.

*Boyer, J., and Wolf, T.K., 1998, GIS and GPS identify viticulture potential in Abstracts and reviews: American Journal of Enology and Viticulture, v. 49, no. 4, p. 449. 
*Boykin, K.G., 2006, Multiscale analysis of habitat, vegetation change, and streamflow as ecological factors affecting population dynamics of Rana chiricahuensis: Las Cruces, New Mexico State University, Doctoral dissertation, 198 p., accessed March 5, 2011, at http://fws-case-12.nmsu.edu/ kboykin/publications/KG\%20Boykin\%20PhD\%20Dissertation\%20Final_Print2.pdf.

*Boykin, K.G., 2008, Fire management over large landscapes-A hierarchical approach, in Narog, M.G., tech. coord., 2002 Fire Conference-Managing fire and fuels in the remaining wildlands and open spaces of the Southwestern United States, Proceedings: Albany, Calif., U.S. Department of Agriculture Forest Service, Pacific Southwest Research Station, General Technical Report PSWGTR-189, p. 201-208, accessed March 3, 2011, at http://gis.fs.fed.us/psw/publications/documents/psw_gtr189/psw_gtr189_201-208_boykin.pdf.

*Boykin, K.G., Boykin, D.I., Stovall, Rusty, and Whitaker, Ryan, 2008, Communication and implementation of GIS data in fire management-A case study, in Narog, M.G., tech coord., 2002 Fire conference-Managing fire and fuels in the remaining wildlands and open spaces of the Southwestern United States, Proceedings: Albany, Calif., U.S. Department of Agriculture Forest Service, Pacific Southwest Research Station, General Technical Report PSW-GTR-189, p. 209-216. *Boykin, K.G., Bradford, D.F., and Kepner, W.G., 2007, Habitat distribution models for 37 vertebrate species addressed by the multi-species habitat conservation plan of Clark County, Nevada: Las Cruces, New Mexico Cooperative Fish and Wildlife Research Unit, unpublished manuscript, 66 p. accessed March 7, 2011, at http://fws-nmcfwru.nmsu.edu/kboykin/MSHCP/MSHCP.doc.

*Boykin, K.G., Bradford, D.F., and Kepner, W.G., 2008, Habitat distribution models for 37 vertebrate species in the Mojave desert ecoregion of Nevada, Arizona, and Utah: Las Cruces, New Mexico Cooperative Fish and Wildlife Research Unit, 139 p.

*Boykin, K.G., Drost, Charles, and Wynne, J.J., 2007, A GAP analysis of terrestrial vertebrate species of the Colorado Plateau-Assessment from the Southwest Regional Gap Analysis Project, in Van Riper, C., III, and Sogge, M.K., eds., The Colorado Plateau III-Intergrating research and resources management for effective conservation: Tucson, University of Arizona Press, p. 77-107.

*Boykin, K.G., Guy, R.K., and Calkins, M.T., 2009, Santa Fe County wildlife habitat GIS modelingWorkshop and conservation priorities: Technical Assistance Report, Las Cruces, New Mexico Cooperative Fish and Wildlife Research Unit, 58 p., accessed March, 2, 2011, at http://fws-case-12. nmsu.edu/case/santafe/documents/Santa_Fe_County_GIS_Final_Report.pdf.

*Bradley, B.A., 2010, Assessing ecosystem threats from global and regional change-Hierarchical modeling of risk to sagebrush ecosystems from climate change, land use and invasive species in Nevada, USA: Ecography, v. 33, p. 198-208.

*Bradley, B.A., and Mustard, J.F., 2008, Comparison of phenology trends by land cover class-A case study in the Great Basin, USA: Global Change Biology, v. 14, no. 2, p. 334-346.

*Brady, L.M., Gray, Floyd, Wissler, C.A., and Guertin, D.P., 2001, Spatial variability of sediment erosion processes using GIS analysis within watersheds in a historically mined region, Patagonia Mountains, Arizona: Tucson, Ariz., U.S. Geological Survey Open-File Report 01-267, 51p.

*Brady, L.M.; Gray, Floyd; Wissler, Craig; and Guertin, Phillip, 2000, GIS analysis of spatial variability of contaminated watershed components in a historically mined region, Arizona, in 2000 ESRI International User Conference, San Diego, Calif., Proceedings: Redlands, Calif., Environmental Systems Research Institute (ESRI), paper 818, accessed February 1, 2011, at http://proceedings.esri.com/library/userconf/proc00/professional/papers/PAP818/p818.htm.

*Brenner, John; Paustian, Keith; Bluhm, George; Cipra, Jan; Easter, Mark; Foulk, Robin; Killian, Kendrick; Moore, Ron; Schuler, Jill; Smith, Phil; and Williams, Steve, 2002, Quantifying the change in greenhouse gas emissions due to natural resource conservation practice application in Nebraska: 
Fort Collins, Colorado State University Natural Resource Ecology Laboratory and U.S. Department of Agriculture Natural Resources Conservation Services, unpublished manuscript, 106 p., accessed March 8, 2011, at http://metadata.dnr.state.ne.us/Carbon/NebraskaNRCS.pdf.

*Brenner, John; Paustian, Keith; Bluhm, George; Cipra, Jan; Easter, Mark; Killian, Kendrick; Schuler, Jill; Smith, Phil; and Williams, Steve, 2001, Phase I progress report-Quantifying the change in greenhouse gas emissions due to natural resource conservation practice application in Nebraska: Fort Collins, Colorado State University Natural Resource Ecology Laboratory and U.S. Department of Agriculture Natural Resources Conservation Services, unpublished manuscript, 43 p., accessed March 29, 2011, at http://www.nrel.colostate.edu/projects/agroeco/projects/statelevel/nebraska/ PhaseI_progress_report.doc.

*Breshears, D.D., Cobb, N.S., Rich, P.M., Price, K.P., Allen, C.D., Balice, R. G., Romme, W.H., Kastens, J.H., Floyd, M.L., Belnap, Jayne, Anderson, J.J., Myers, O.B., and Meyer, C.W., 2005, Regional vegetation die-off in response to global-change-type drought: Proceedings of the National Academy of Sciences of the United States of America, v. 102, no. 42, p. 15144-15148.

*Briggs, N.A., and Sader, S.A., 2009, Tracking forest change and development using low-cost remote sensing imagery and GIS integration: Northern Journal of Applied Forestry, v. 26, no. 4, p. 148-155.

*Brinda, J.C., Stark, L.R., Shevock, J.R., and Spence, J.R., 2007, An annotated checklist of the bryophytes of Nevada, with notes on collecting history in the state: The Bryologist, v. 110, no. 4, p. 673-705.

*Briskey, J.A., Schulz, K.J., Mosesso, J.P., Horwitz, L.R., and Cunningham, C.G., 2007, Environmental planning issues and a conceptual global assessment of undiscovered nonfuel mineral resources, in Briskey, J.A., and Schulz, K.J., eds., Proceedings for a Workshop on Deposit Modeling, Mineral Resource Assessment, and Their Role in Sustainable Development, Rio de Janeiro, Brazil: U.S. Geological Survey Circular 1294, p. 19-28. (Also available at http://pubs.usgs.gov/circ/2007/1294/.)

*Bristow, K.D., Boe, S.R., and Ockenfels, R.A., 2005, Predicting habitat suitability for wildlife in southeastern Arizona using geographic information systems - Scaled quail, a case study, in Gottfried, G.J., Gebow, B.S., Eskew, L.G., and Edminster, C.B., comps., Connecting mountain islands and desert seas-Biodiversity and management of the Madrean Archipelago II, Proceedings: Fort Collins, Colo., U.S. Department of Agriculture Forest Service, Rocky Mountain Research Station, RMRS-P36, p. 57-61.

*Brooks, R.P., Wardrop, D.H., and Bishop, J.A., 2004, Assessing wetland condition on a watershed basis in the Mid-Atlantic region using synoptic land-cover maps: Environmental Monitoring and Assessment, v. 94, nos. 1-3, p. 9-22.

*Brough, A.M., 2009, Summer home range fidelity in adult female elk (Cervus elaphus) in northwestern Colorado: Logan, Utah State University, Master's thesis, 57 p.

*Brown, K.M.; George, Gerald; and Daniel, Wesley, 2010, Urbanization and a threatened freshwater mussel—Evidence from landscape scale studies: Hydrobiologica, v. 655, no. 1, p. 189-196.

*Brubaker, D.L., Brubaker, K.L, and Thompson, B.C., 2003, Raptor and Chihuahuan raven nesting on decommissioned telephone-line poles in the northern Chihuahuan Desert: Journal of Raptor Research, v. 37 , no. 2, p. $135-146$.

*Budlong, R.C., [n.d.], The use of spatial data in creating a riparian buffer suitability modelWhitewater river watershed, Minnesota: Winona, St. Mary's University of Minnesota, unpublished manuscript, 11 p., accessed March 16, 2011, at http://www.gis.smumn.edu/GradProjects/BudlongB.pdf.

*Bunya, S., Dietrich, J.C., Westerink, J.J., Ebersole, B.A., Smith, J.M., Atkinson, J.H., Jensen, R., Resio, D.T., Luettich, R.A., Dawson, C., Cardone, V.J., Cox, A.T., Powell, M.D., Westerink, H.J., 
and Roberts, H.J., 2010, A high-resolution coupled riverine flow, tide, wind, wind wave, and storm surge model for southern Louisiana and Mississippi. Part I-Model development and validation: Monthly Weather Review, v. 138, p. 345-377.

*Burger, Michael; Halperin, Jamie; and Liner, Jillian, 2003, Identification of IBAs-Bird conservation planning using GAP analysis data: New York, Audubon Important Bird Areas Program, 22 p., accessed January 10, 2011, at http://web4.audubon.org/bird/iba/iba_resources $/$ Sites $/$ Site\% 20Information/NYIBA\%20spatial\%20analysis\%202003_no_images.doc.

*Burns, K.S., Schoettle, A.W., Jacobi, W.R., and Mahalovich, M.F., 2007, White pine blister rust in the Rocky Mountain region and options for management-Biological evaluation R2-07-04: Golden, Colo., U.S. Department of Agriculture Forest Service, 37 p.

*Burns, K.S., Schoettle, A.W., Jacobi, W.R., and Mahalovich, M.F., 2008, Options for the management of white pine blister rust in the Rocky Mountain region: Fort Collins, Colo., U.S. Department of Agriculture Forest Service, Rocky Mountain Research Station, General Technical Report RMRSGTR-206, 26 p.

*Bussen, Patrick, 2009, Analysis of a rapid soil erosion assessment tool: Manhattan, Kansas State University, Master's thesis, 90 p., accessed March 24, 2011, at http://krex.kstate.edu/dspace/

bitstream/2097/2351/1/PatrickBussen2009.pdf.

*Buyantuyev, A., and Wu, J., 2009, Urbanization alters spatiotemporal patterns of ecosystem primary production - A case study of the Phoenix metropolitan region, USA: Journal of Arid Environments, v. 73, p. 512-520.

*Calkins, M.T., Boykin, K.G., Andersen, M.C., 2009, Invasive potential of feral pigs in New MexicoPreliminary assessment and future directions: Technical Assistance Report, Las Cruces, New Mexico Cooperative Fish and Wildlife Research Unit, 18 p., accessed March 3, 2011, at http://fws-case-12 .nmsu.edu/kboykin/publications/FeralPigs_APHIS_Tech_Report_2009.pdf.

Campbell, David; Picard-Aitken, Michelle; Côté, Grégoire, Caruso, Julie; Valentim, Rodolfo; Edmonds, Stuart; Williams, G.T.; Macaluso, Benoît; Robitaille, J.P.; Bastien, Nicolas; Laframboise, M.C.; Lebeau, L.M.; Mirabel, Philippe; Larivière, Vincent; and Archambault, Éric, 2010, Bibliometrics as a performance measurement tool for research evaluation-The case of research funded by the National Cancer Institute of Canada: American Journal of Evaluation, v. 31, no. 1, p. 66-83.

*Caratti, J.F., 2006, The LANDFIRE Prototype Project reference database, chap. 4 of Rollins, M.G., and Frame, C.K., tech. eds., The LANDFIRE Prototype Project-Nationally consistent and locally relevant geospatial data for wildland fire management: Fort Collins, Colo., U.S. Department of Agriculture Forest Service, Rocky Mountain Research Station, General Technical Report RMRSGTR-175, p. 69-98.

*Carroll, Carlos, 1999, Regional-scale predictive models of the distribution of the California spotted owl-An exploratory analysis: Orleans, Calif., Klamath Center for Conservation Research, 21 p., accessed January 10, 2011, at http://www.klamathconservation.org/docs/calowlreport.pdf.

*Carroll, Carlos, Noss, R.F. and Paquet, P.C., 2001, Carnivores as focal species for conservation planning in the Rocky Mountain region: Ecological Applications, v. 11, no. 4, p. 961-980.

*Carroll, Carlos, Phillips, M.K., Schumaker, N.H., and Smith, D.W., 2003, Impacts of landscape change on wolf restoration success - Planning a reintroduction program based on static and dynamic spatial models: Conservation Biology, v. 17, no. 2, p. 536-548.

*Casey, Frank; McMurray, Anna; Kroeger, Timm; Michalak, Julia; and Manalo, Paula, 2008, The cost of a comprehensive national wildlife habitat conservation system-A project completion report for the wildlife habitat policy research program: Washington, D.C., Defenders of Wildlife, accessed March 5, 2011, at http://www.manyone.net/files/46701_46800/46782/file_46782.pdf. 
*Cassidy, K.M., 2005, Seasonal distribution maps, in Wahl, T.R., Tweit, Bill, and Mlodinoiw, S.G., eds., Birds of Washington-Status and distribution: Corvallis, Oregon State University Press, p. 10-11.

*Cassidy, K.M., and Grue, C.E., 2000, The role of private and public lands in conservation of at-risk vertebrates in Washington State: Wildlife Society Bulletin, v. 28, no. 4, p. 1060-1076.

*Cassidy, K.M., and Grue, C.E., 2006, From global thought to location action-Translating regional conservation priorities to helpful local guidelines in Abstracts from the 2006 Annual Meetings of the Society for Northwestern Vertebrate Biology and the Washington Chapter of the Wildlife Society held jointly at Evergreen State College, Washington, March 27-April 1, 2006: Northwestern Naturalist, v. 87, p. 164.

*Cavalieri, V.S., O'Connell, T.J., and Leslie, D.M., Jr., 2009, A bird community on the edge-Habitat use of forest songbirds in eastern Oklahoma, in Rich, T.D., ed., Tundra to Tropics - Connecting Birds, Habitats, and People, Fourth International Partners in Flight Conference, McAllen, Tex., February 13-16, 2008, Proceedings: St. Paul, Minn., U.S. Department of Agriculture Forest Service, Northern Research Station, p. 118-127, accessed March 4, 2011, at http://www.pwrc.usgs.gov/PIF/pubs/McAllenProc/articles/PIF09_Bird\%20Communities/Cavalieri_PI F09.pdf.

*Charlet, D.A., 2002, Island biogeography and vegetation mapping - Conservation lessons from the American West: Symposium on Technology and Marketing of Lentinula Mushroom, 2002, Zhumadian, Henan Province, China, 19 p., accessed March 3, 2011, at http://csn.edu/science/Charlet/chinatalk3.pdf.

*Chen, Y.D., McCutcheon, S.C., Carsel, R.F., Donigian, A.S., Jr., Cannell, J.R., and Craig, J.P., 1995, Validation of HSPF for the water balance simulation of the Upper Grande Ronde watershed, Oregon, USA in Petts, Geoffrey, ed., Man's influence on freshwater ecosystems and water use [International symposium, Boulder, Colo., July 1995, Proceedings]: International Association of Hydrological Sciences publication no. 230, p. 3-13.

*Chung, Y.J., and Winer, A.M., 1999, Field assessment of the California Gap Analysis Program database for San Diego county: Madroño, v. 46, no. 4, p. 187-198.

*Church, R.L., Stoms, D.M., and Davis, F.W., 1996, Reserve selection as a maximal covering location problem: Biological Conservation, v. 76, p. 105-112.

*Clark, F.S., and Slusher, R.B., 2000, Using spatial analysis to drive reserve design-A case study of a national wildlife refuge in Indiana and Illinois (USA): Landscape Ecology, v. 15, no. 1, p. 75-84.

*Clark, J.D., Dobey, Steven, Masters, D.V., Scheick, B.K., Pelton, M.R., and Sunquist, M.E., 2005, American black bears and bee yard depredation at Okefenokee Swamp, Georgia: Ursus, v. 16, no. 2, p. 234-244.

*Cleland, D.T., Crow, T.R., Saunders, S.C., Dickmann, D.I., Maclean, A.L., Jordan, J.K., Watson, R.L., Sloan, A.M., and Brosofske, K.D., 2004, Characterizing historical and modern fire regimes in Michigan (USA) - A landscape ecosystem approach: Landscape Ecology, v. 19, p. 311-325.

*Clinton, N.E.; Gong, Peng; and Scott, Klaus, 2006, Quantification of pollutants emitted from very large wildland fires in southern California, USA: Atmospheric Environment, v. 40, no. 20, p. 3686-3695.

*Clinton, Nicholas; Scarborough, James; Tian, Yong; and Gong, Peng, 2003, A GIS based emissions estimation system for wildlife and prescribed burning, in $12^{\text {th }}$ International Emission Inventory Conference, San Diego, Calif., April 29-May 1, 2003: Berkeley, Calif., University of California Center for the Assessment and Monitoring of Forest and Environmental Resources (CAMFER), 14 p., accessed March 4, 2011, at http://www.epa.gov/ttn/chief/conferencelei12/part/clinton.pdf. 
*Cogan, Christopher, 1997, California biodiversity project-Application of ecological data to biodiversity analysis, in 1997 ESRI International User Conference, San Diego, Calif., Proceedings: Redlands, Calif., Environmental Systems Research Institute (ESRI), paper 235, accessed January, 26, 2011, at http://ksumail.kennesaw.edu/ mpatters/4405/biodiversity.pdf.

*Cole, Kenneth, 2003, Map sources for the ranges of one and two-needled pinions: Flagstaff, Ariz., U.S. Geological Survey, Colorado Plateau Research Station, accessed March, 2, 2011, at http://sbsc.wr.usgs.gov/cprs/research/projects/global_change/RangeMaps/PinyonMapSources.pdf.

*Comer, Pat; Menard, Shannon; Tuffly, Mike; Kindscher, K.; Rondeau, R.; Jones, G.; Steinuaer, G.; Schneider, R.; and Ode, D.; 2003, Upland and wetland ecological systems in Colorado, Wyoming, South Dakota, Nebraska, and Kansas - Report and map to the National Gap Analysis Program: Arlington, Va., NatureServe, 18 p. plus appendices, accessed March 12, 2011, at http://72-166-117170.dia.static.qwest.net/library/usfsRegionIIecology.pdf.

*Conway, C.J., and Kirkpatrick, Chris, 2007, Effect of forest fire suppression on buff-breasted flycatchers: Journal of Wildlife Management, v. 71, no. 2, p. 445-457.

*Cook, R.R., Flather, C.H., and Wilson, K.R., 2000, Faunal characteristics of the southern Rocky Mountains of New Mexico-Implications for biodiversity analysis and assessment: Fort Collins, Colo., U.S. Department of Agriculture Forest Service, Rocky Mountain Research Station, General Technical Report RMRS-GTR-58, 55 p.

*Coops, N.C., and Waring, R.H., 2001a, Assessing forest growth across southwestern Oregon under a range of current and future global change scenarios using a process model, 3-PG: Global Change Biology, v. 7, p. 15-29.

*Coops, N.C., and Waring, R.H., 2001b, The use of multiscale remote sensing imagery to derive regional estimates of forest growth capacity using 3-PGS: Remote Sensing of Environment, v. 75, p. 324-334.

*Crawford, P.H.C., and Hoagland, B.W., 2010, Using species distribution models to guide conservation at the state level-The endangered American burying beetle (Nicrophorus americanus) in Oklahoma: Journal of Insect Conservation, v. 14, no. 5, p. 511-521.

*Crist, M.R., and Wilmer, Bo, 2002, Roadless areas - The missing link in conservation —An analysis of biodiversity and landscape connectivity in the northern Rockies: Washington, D.C., The Wilderness Society, 30 p., accessed March 7, 2011, at http://www.heritageforests.org/fact/missing_link.pdf.

*Crist, M.R., Wilmer, Bo, and Aplet, G.H., 2005, Assessing the value of roadless areas in a conservation reserve strategy-Biodiversity and landscape connectivity in the northern Rockies: Journal of Applied Ecology, v. 42, p. 181-191.

*Crist, P., 2003, A comparison of the effect of unit of analysis on the conservation status of terrestrial vertebrates in the western United States: Moscow, University of Idaho, Doctoral dissertation, $171 \mathrm{p}$. *Crist, P.J., Kohley, T.W., and Oakleaf, John, 2000, Assessing land-use impacts on biodiversity using an expert systems tool: Landscape Ecology, v. 15, no. 1, p. 47-62.

*Crowe, R.E., 1996, Use of gap analysis in regional planning in southern California, in Scott, J.M., Tear, T.H., and Davis, F.W., eds., Gap analysis - A landscape approach to biodiversity planning: Bethesda, Md., American Society for Photogrammetry and Remote Sensing, p. 221-238.

*Curnutt, J.L., Comiskey, Jane, Nott, M.P., and Gross, L.J., 2000, Landscape-based spatially explicit species index models for Everglades restoration: Ecological Applications, v. 10, no. 6, p. 1849-1860. *Curto, Michael; Hallock, Brent; and Scharff, Misty, 2002, A GIS to select plant species for erosion control along California highways in International Erosion Control Association, Orlando, Fla., February 25-March 1, 2002, Proceedings: California State University, Sacramento, Storm Water 
Program, 11 p., accessed February 28, 2011, at

http://www.owp.csus.edu/research/papers/papers/PP016.pdf.

*Cushman, S.A., McGarigal, Kevin, and Neel, M.C., 2008, Parsimony in landscape metrics - Strength, universality, and consistency: Ecological Indicators, v. 8, p. 691-703.

*Dadisman, S.V., Flocks, J.G., and Calderon, Karynna, 2005, LASED geodatabase-A tool to manage, analyze, distribute, and archive geologic data from the Louisiana coastal zone, in Soller, D.R., ed., Digital mapping techniques '05-Workshop Proceedings, Baton Rouge, La., April 24-27, 2005: U.S. Geological Survey Open-File Report 2005-1428, p. 81-89.

*Daggett, Steve; Boule', Marc; Bernert, J.A.; Eilers, J.M.; Blok, Elaine; Peters, Dennis; and Morlan, J.C., 1998, Wetland and land use change in the Willamette Valley, Oregon-1982-1994, Volume 1, Final report: Salem, Oreg., Wetlands Program, Division of State Lands, unpublished manuscript, 38 p., accessed April 6, 2011, at http://www.ohcs.oregon.gov/DSL/WETLAND/docs/Final_Report.pdf?ga=t.

*Danks, Z.D., and Porter, W.F., 2010, Temporal, spatial, and landscape habitat characteristics of moosevehicle collisions in western Maine: Journal of Wildlife Management, v. 74, no. 6, p. 1229-1241.

*Dark, S.J., 2004, The biogeography of invasive alien plants in California-An application of GIS and spatial regression analysis: Diversity and Distributions, v. 10, no. 1, p. 1-9.

*Dark, Shawna; Maas, Regan; Mejia, J.D.; and Belliappa, Namrata, 2006, An examination of wetland diversity in Ventura County, California: Yearbook of the Association of Pacific Coast Geographers, v. 68, p. 79-93.

* Dauwalter, D.C., and Jackson, J.R., 2004, A provisional fish index of biotic integrity for assessing Ouachita mountains streams in Arkansas, U.S.A.: Environmental Monitoring and Assessment, v. 91, no. $1-3$, p. $27-57$.

*Dauwalter, D.C., and Pert, E.J., 2003, Electrofishing effort and fish species richness and relative abundance in Ozark highland streams of Arkansas: North American Journal of Fisheries Management, v. 23, no. 4, p. 1152-1166.

*Dauwalter, D.C., Pert, E.J., and Keith, W.E., 2003, An index of biotic integrity for fish assemblages in Ozark highland streams of Arkansas: Southeastern Naturalist, v. 2, no. 3, p. 447-468.

*Davis, A.M., 2006, Public resource allocation for programs aimed at managing woody plants on the Edwards Plateau - Water yield, wildlife habitat, and carbon sequestration: College Station, Texas A\&M University, Master's thesis, 108 p., accessed February 3, 2011, at https://repository.tamu.edu/handle/1969.1/3938.

*Davis, D.B., 2009, Predictive modeling of sulfur flower buckwheat (Eriogonum umbellatum Torrey) using non-parametric multiplicative regression analysis: Provo, Utah, Brigham Young University, Master's thesis, 32 p., accessed March 5, 2011, at http://contentdm.lib.byu.edu/ETD/image/etd3224.pdf.

*Davis, F.W., Stoms, D.M., and Andelman, Sandy, 1999, Systematic reserve selection in the USA-An example from the Columbia Plateau ecoregion: Parks, v. 9, no. 1, p. 31-41.

Davis, G., and Royle, Pamela, 1996, A comparison of Australian university output using journal impact factors: Scientometrics, v. 35, no. 1, p. 45-58.

*Davis, T.S., 2009, The ants of South Carolina: Clemson, S.C., Clemson University, Doctoral dissertation, $257 \mathrm{p}$.

*Dawson, E.M.P., 2005, Predicting species richness patterns in the Chihuahuan desert-A GIS analysis of spatial and ecological data: Lubbock, Texas Tech University, Doctoral dissertation, $436 \mathrm{p}$.

*Dean, D.J., Wilson, K.R., and Flather, C.H., 1997, Spatial error analysis of species richness for a Gap Analysis map: Photogrammetric Engineering \& Remote Sensing, v. 63, no. 10, p. 1211-1217. 
*Dean, Tom; Ferdana, Zach; White, Jacques; and Tanner, Curtis, 2001, Identifying and prioritizing sites for potential estuarine habitat restoration in Puget Sound's Skagit River delta: Puget Sound Research, 12 p., accessed March 18, 2011, at http://whatcomsalmon.whatcomcounty.org/documents/psat/3c_dean.pdf.

*DeAngelis, D.L, Duke-Sylvester, S.M., and Gross, L.J., 2004, Modeling the effects of hydrology on fire, vegetation dynamics, and their interaction in the Florida Everglades: U.S Geological Survey, Fact Sheet 2004-3110, accessed March 3, 2011, at http://www.briarcliff.edu/departments/biol/BIOL\%2052IR/fs-2004-3110-DeAngelis.pdf.

*DeAngelis, D.L., Gross, L.J., Huston, M.A., Wolff, W.F., Fleming, D.M., Comiskey, E.J., and Sylvester, S.M., 1998, Landscape modeling for Everglades ecosystem restoration: Ecosystems, v. 1, no. 1, p. 64-75.

*Deblinger, R.D., Field, Rebecca, Finn, J.T., and Loomis, D.K., 2004, A conceptual model of suburban wildlife management-A case study of beaver in Massachusetts, in Shaw, W.W., Harris, L.K., and Vandruff, Larry, eds., 4th International Symposium on Urban Wildlife Conservation, Tucson, Ariz., May 1-5, 1999, Proceedings: p. 245-252, accessed February 28, 2011, at http://citeseerx.ist.psu.edu/viewdoc/download?doi=10.1.1.163.7884\&rep $=$ rep $1 \&$ type $=p d f$.

*Decker, Karin, 2007, The potential distribution and landscape integrity of Frankenia jamesii (James' seaheath) in southeastern Colorado: Fort Collins, Colorado Natural Heritage Program, Colorado State University, unpublished manuscript, 16 p., accessed March 29, 2011, at http://www.cnhp.colostate.edu/download/documents/2007/Frankenia_distribution_modeling.pdf.

*Decker, Karin; Lavender, Amy; Handwerk, Jill; and Anderson, D.G., 2006, Modeling the potential distribution of three endemic plants of the Northern Piceance and Uinta Basins: Fort Collins, Colorado Natural Heritage Program, Colorado State University, unpublished manuscript, 17 p., accessed January 10, 2011, at http://www.cnhp.colostate.edu/download/documents/2006/PEGR_LECO_PHOB_report.pdf.

*Dees, C.S., Clark, J.D., and Van Manen, F.T., 2001, Florida panther habitat use in response to prescribed fire: Journal of Wildlife Management, v. 65, no. 1, p. 141-147.

*DellaSala, D.A., Staus, N.L., Strittholt, J.R., Hackman, Arlin, and Iacobelli, Antonio, 2001, An updated protected areas database for the United States and Canada: Natural Areas Journal, v. 21, no. 2, p. 124-135.

*Dennis, D.L., 2010, Genetic analysis of dispersal and population dynamics of the southeastern coyote (Canis latrans): Auburn, Ala., Auburn University, Master's thesis, 79 p., accessed March 3, 2011, at http://etd.auburn.edu/etd/bitstream/handle/10415/2169/DennisMSThesis5.13FINAL.pdf?sequence=4. *Dhami, Ishwar, and Deng, Jinyang, 2010, Modeling the scenic beauty of the Highland Scenic Highway, West Virginia in Watts, C.E., Jr., and Fisher, C.L., eds., 2009 Northeastern Recreation Research Symposium, Proceedings: Newtown Square, Pa., U.S. Department of Agriculture Forest Service, Northern Research Station, General Technical Report NRS-P-66, p. 180-188.

*Diamond, D.D., True, C.D., Gordon, T.M., Sowa, S.P., Foster, W.E., and Jones, B.K., 2005, Influence of targets and assessment region size on perceived conservation priorities: Environmental Management, v. 35, no. 2, p. 130-137.

*Didier, K.A., and Porter, W.F., 1999, Large-scale assessment of potential habitat to restore elk to New York State: Wildlife Society Bulletin, v. 27, no. 2, p. 409-418.

*Diefenbach, D.R., Riegner, C.F., and Hardisky, T.S., 2000, Harvest and reporting rates of game-farm ring-necked pheasants: Wildlife Society Bulletin, v. 28, no. 4, p. 1050-1059.

*Dietz, R.W., 2000, The use of GIS for integrated watershed analysis - Integration of environmental models with GIS in the Upper Roanoake River Watershed: Blacksburg, Virginia Polytechnic Institute 
and State University, Master's thesis, 80 p., accessed March 7, 2011, at http://scholar.lib.vt.edu/theses/available/etd-04282000-12460000/unrestricted/DietzThesis.pdf.

*Dietz, R.W., and Czech, Brian, 2005, Conservation deficits for the continental United States-An ecosystem gap analysis: Conservation Biology, v. 19, no. 5, p. 1478-1487.

*Dilts, T.E., Sibold, J.S., and Biondi, Franco, 2009, A weights-of-evidence model for mapping the probability of fire occurrence in Lincoln County, Nevada: Annals of the Association of American Geographers, v. 99, no. 4, p. 712-727.

*DiMauro, Danielle, and Hunter, M. L., Jr., 2002, Reproduction of amphibians in natural and anthropogenic temporary pools in managed forests: Forest Science, v. 48, no. 2, p. 397-406.

*Dissanayake, S.T.M., Önal, Hayri, Westervelt, J.D., and Balbach, H.E., 2010a, Optimum land allocation for species protection and military training on DoD installations, Agricultural and Applied Economics Association 2010 Annual Meeting, July 25-27, 2010, Denver, Colo., Poster: Urbana, University of Illinois at Urbana-Champaign, accessed March 3, 2011, at http://ageconsearch.umn.edu/handle/61767.

*Dissanayake, S.T.M., Önal, Hayri, Westervelt, J.D., and Balbach, H.E., 2010b, Optimum selection of clustered conservation areas for species relocation: Urbana, University of Illinois at UrbanaChampaign, unpublished manuscript, accessed March 8, 2011, at http://www.feem-project.net/ belpasso_2010/files/students_papers/Dissanayake.pdf.

*Doleman, W.H., 2005, Environmental constraints on forager mobility and the use of cultigens in southeastern Arizona and southern New Mexico, chap. 5 of Vierra, B.J., ed., The late archaic across the borderlands-From foraging to farming: Austin, University of Texas Press, p. 113-140.

*Donaldson, B.M., and Weber, J.T., 2006, Use of a GIS-based model of habitat cores and landscape corridors for the Virginia Department of Transportation's project planning and environmental scoping: Charlottesville, Virginia Transportation Research Council, 25 p. accessed March 4, 2011, at http://www.virginiadot.org/vtrc/main/online_reports/pdf/07-r14.pdf.

*Donnelly, S.P., 2003, Linking landscape pattern to social process-A multi-scale analysis of farm woodlots in northern Indiana: Bloomington, Indiana University, Department of Geography, Center for the Study of Institutions, Population and Environmental Change, 18 p., accessed February 28, 2011, at http://www.ucgis.org/summer03/studentpapers/shanondonnelly.pdf.

*Doren, R.F., Rutchey, Ken, and Welch, Roy, 1999, The Everglades-A perspective on the requirements and applications for vegetation map and database products: Photogrammetric Engineering \& Remote Sensing, v. 65, no. 2, p. 155-161.

*Driese, K.L., 2004, The application of geographic information science to environmental research: Laramie, University of Wyoming, Doctoral dissertation, $182 \mathrm{p}$.

*Driese, K.L., Reiners, W.A., Merrill, E.H., and Gerow, K.G., 1997, A digital land cover map of Wyoming, USA - A tool for vegetation analysis: Journal of Vegetation Science, v. 8, p. 133-146. *Druckenbrod, D.L., Dale, V.H., and Olsen, L M., 2007, Comparing current and desired ecological conditions at a landscape scale in the Cumberland Plateau and Mountains, USA: Journal of Land Use Science, v. 1, no. 2, p. 169-189.

*Dumas, J.P., 2005, A spatial decision support system utilizing data from the Gap Analysis Program and a Bayesian belief network: Mississippi State, Mississippi State University, Master's thesis, $104 \mathrm{p}$. *Dushku, Aaron, and Brown, Sandra, 2002, Yolo and Sacramento County, California - Comparisons of grazing land baselines: Arlington, Va., Winrock International, accessed March 4, 2011, at http://www.winrock.org/ecosystems/files/Product\%208\%20domestic\%20baselines\%20for\% 20rangelands.pdf. 
*Dymond, R.L., Regmi, B., Lohani, V.K., and Dietz, R., 2004, Interdisciplinary web-enabled spatial decision support system for watershed management: Journal of Water Resources Planning and Management, v. 130, no. 4, p. 290-300.

*Dzialak, M.R., Carter, K.M., and Lacki, M.J., 2007, Perch site selection by reintroduced peregrine falcons Falco peregrinus: Wildlife Biology, v. 13, no. 3, p. 225-230.

*Earl, Jeffrey; Kluender, Richard; and Brewington, Robert, 2000, A method to predict the potential regional long-term timber supply using GIS and other publicly available data: Journal of the Arkansas Academy of Science, v. 54, p. 51-58.

*Earnhardt, T.S., McKerrow, Alexa, and Terando, Adam, 2009. Modeling the effects of climate change on vegetation dynamics and species habitats in the southern Atlantic Coastal Plain [abs.], in the Ecological Society of America (ESA) Annual Meeting, 94 ${ }^{\text {th }}$, Albuquerque, New Mex., August 2-7, 2009: Washington, D.C., ESA, accessed March 3, 2011 at http://eco.confex.com/eco/2009/techprogram/P16521.HTM.

*Edwards, T.C., Jr., Deshler, E.T., Foster, Dan, and Moisen, G.G., 1996, Adequacy of wildlife habitat relation models for estimating spatial distributions of terrestrial vertebrates: Conservation Biology, v. 10 , no. 1 , p. $263-270$.

**Edwards, T.C., Homer, C.G., Bassett, S.D., Falconer, Allan, Ramsey, R.D., Wight, D.W., 1995, Utah gap analysis - An environmental information system: Logan, Utah State University, U.S. Department of Interior National Biological Service.

*Edwards, T.C., Jr., Moisen, G.G., Frescino, T.S., and Lawler, J.J., 2003, Use of forest inventory and analysis information in wildlife habitat modeling - A process for linking multiple scales, in McRoberts, R.E., Reams, G.A., Van Deusen, P.C., and Moser, J.W., eds., Third Annual Forest Inventory and Analysis Symposium, Traverse City, Mich., October 17-19, 2001, Proceedings: St. Paul, Minn., U.S. Department of Agriculture Forest Service, North Central Research Station, General Technical Report NC-230, p. 188-194.

*Efroymson, R.A.; Dale, V.H.; Baskaran, L.M.; Chang, Michael; Aldridge, Matthew; and Berry, M.W., 2005, Planning transboundary ecological risk assessments at military installations: Human and Ecological Risk Assessment, v. 11, p. 1193-1215.

*Eisen, R.J.; Enscore, R.E.; Biggerstaff, B.J.; Reynolds, P.J.; Ettestad, Paul; Brown, Ted; Pape, John; Tanda, Dale; Levy, C.E.; Engelthaler, D.M.; Cheek, James; Bueno, Rudy, Jr.; Targhetta, Joseph; Montenieri, J.A.; and Gage, K.L., 2007, Human plague in the southwestern United States, 19572004 - Spatial models of elevated risk of human exposure to Yersinia pestis: Journal of Medical Entomology, v. 44, no. 3, p. 530-537.

*Eisen, R.J.; Glass, G.E.; Eisen, Lars; Cheek, James; Enscore, R.E.; Ettestad, Paul; and Gage, K.L., 2007, A spatial model of shared risk for plague and hantavirus pulmonary syndrome in the southwestern United States: American Journal of Tropical Medicine and Hygiene, v. 77, no. 6, p. 999-1004.

*Eisen, R.J., Lane, R.S., Fritz, C.L., Eisen, Lars, 2006, Spatial patterns of Lyme disease risk in California based on disease incidence data and modeling of vector-tick exposure: American Journal of Tropical Medicine and Hygiene, v.75, no. 4, p. 669-676.

*Eisen, R.J.; Reynolds, P.J.; Ettestad, Paul; Brown, Ted; Enscore, R.E.; Biggerstaff, B.J.; Cheek, James; Bueno, Rudy; Targhetta, Joseph; Montenieri, J.A.; and Gage, K.L., 2007, Residence-linked human plague in New Mexico-A habitat-suitability model: American Journal of Tropical Medicine and Hygiene, v. 77, no. 1, p. 121-125. 
*Ekness, Paul, and Randhir, Timothy, 2007, Effects of riparian areas, stream order, and land use disturbance on watershed-scale habitat potential-An ecohydrological approach to policy: Journal of the American Water Resources Association, v. 43, no. 6, p. 1468-1482.

*Eli, R.N., Fletcher, J.J., Galya, T.A., Strager, M.P., Lamont, S.J., Sun, Qingyun, and Churchill, J.B., 2004, Hydrologic modeling tools for cumulative hydrologic impact assessment of West Virginia coal mine permits, in Geospatial Conference 2004, Advanced Integration of Geospatial Technologies in Mining and Reclamation, Atlanta, Ga., December 7-9, 2004: Morgantown, West Virginia University, 27 p., accessed January 17, 2011, at http://www.tips.osmre.gov/geospatial/post-conference/papers/ eli_wv_final.pdf.

*Enquist, C.A.F., and Gori, D.F., 2008, Application of an expert system approach for assessing grassland status in the U.S.-Mexico borderlands-Implications for conservation and management: Natural Areas Journal, v. 28, no. 4, p. 414-428.

*Enwright, Nicholas, and Hudak, P.F., 2009, Spatial distribution of nitrate and related factors in the High Plains Aquifer, Texas: Environmental Geology, v. 58, no. 7, p. 1541-1548.

*Ervin, G.N., and Linville, M J., 2006. The landscape context of plant invasions in Mississippi wetlands, in Brasher, K., ed., 36th Annual Mississippi Water Resources Conference, April 25-26, 2006, Proceedings: Mississippi State, Mississippi State University, 11 p., accessed February 28, 2011, at http://www.cavs.msstate.edu/publications/docs/2006/04/4056WRC_2006_Ervin\&Linville.pdf

*Espinosa, Shawn, and Phenix, Ralph, 2008, Effects of wildfire (1999-2007) on greater sage-grouse (Centrocercus urophasianus) and key ecological sagebrush systems that they depend on in Nevada: Reno, Nevada Department of Wildlife Game Division, unpublished manuscript, 8 p., accessed March 3, 2011, at http://www.ndow.org/wild/conservation/sg/resources/Effects\%20of\%20Fire\%20on\% 20GSG\%20and\%20Sagebrush\%20in\%20NV.pdf.

*Estrada-Peña, Agustín, 2009, Diluting the dilution effect—A spatial Lyme model provides evidence for the importance of habitat fragmentation with regard to the risk of infection: Geospatial Health, v. 3, no. 2, p. 143-155.

*Fadali, Elizabeth; Harris, T.R.; Curtis, Kynda; Dick, Robert; and Balazas, Simona, 2006, Analysis of potential industrial demands of pinyon-juniper resources in Lincoln and White Pine Counties: University of Nevada, Reno, University Center for Economic Development, Department of Resource Economics, Technical Report UCED 2005/06-9, 100 p., accessed March 5, 2011, at http://lcrda.com/images/UNRJanuary2006.doc.

*Fairbanks, D.H.K. and McGwire, K.C., 2004, Patterns of floristic richness in vegetation communities of California-Regional scale analysis with multi-temporal NDVI: Global Ecology and Biogeography, v. 13, p. 221-235.

*Falzarano, S.R., and Thomas, K.A., 2004, Fuzzy set and spatial analysis techniques for evaluating thematic accuracy of a land-cover map, chap. 14 of Lunetta, R.S., and Lyon, J.G., eds., Remote sensing and GIS accuracy assessment: Boca Raton, Fla., CRC Press, p. 189-208.

Fava, G.A., and Ottolini, F., 2000, Impact factors versus actual citations: Psychotherapy and Psychosomatics, v. 69, no. 6, p. 285-286.

*Fecske, D.M., Jenks, J.A., and Smith, V.J., 2002, Field evaluation of a habitat-relation model for the American marten: Wildlife Society Bulletin, v. 30, no. 3, p. 775-782.

*Feeney, Dennis; Beauvais, Gary; Coupal, Roger; Lanning, Shawn; Lieske, Scott; Nibbelink, Nathan; and Nordyke, Kirk, 2004, Big game migration corridors in Wyoming: Wyoming Open Spaces Bulletin (B-1155), 6 p., accessed February 26, 2011, at http://www.uwyo.edu/wynddsupport/docs/Reports/WYNDDReports/N04FEE01WYUS.pdf. 
*Feist, B.E., Steel, E.A., Pess, G.R., and Bilby, R.E., 2003, The influence of scale on salmon habitat restoration priorities: Animal Conservation, v. 6, p. 271-282.

*Feliciano, I.L., 2008, Risk assessment of seismic activity in Mayagüez-Puerto Rico using GIS: Mayagüez, Puerto Rico, unpublished undergraduate report, 43 p., accessed March 3, 2011, at http://gers.uprm.edu/pdfs/topico_ivelisse.pdf.

*Ferguson, H.L., Robinette, Kevin, and Stevenson, Matt, 2004, Searching for the best science available - A method for identifying a corridor-open space system for land use plannning, in Shaw, W.W., Harris, L.K., and Vandruff, Larry, eds., 4th International Symposium on Urban Wildlife Conservation, Tucson, Ariz., May 1-5, 1999, Proceedings: p. 347-356, accessed March 18, 2011, at http://ag.arizona.edu/pubs/adjunct/snr0704/snr07043p.pdf.

*Fertig, Walter, and Thurston, Robert, 2003, Modeling the potential distribution of BLM sensitive and USFWS threatened and endangered plant species in Wyoming: Laramie, Wyoming Natural Diversity Database, University of Wyoming, 44 p., accessed January 17, 2011, at http://www.uwyo.edu/wynddsupport/docs/Reports/WYNDDReports/U03FER01WYUS.pdf.

*Fieberg, J.R., Zicus, M.C., and Hertel, Dan, 2006, Using GIS to predict mallard nest structure occupancy, in Wingate, P.J., Kimmel, R.O., Lawrence, J.S., and Lenarz, M.S., eds., Summaries of wildlife research findings 2005: St. Paul, Minnesota Department of Natural Resources, p. 61-72, accessed March 12, 2011, at http://www.leg.state.mn.us/docs/2006/Other/060492.pdf\#page=72.

*Fisher, H., Butcher, J., Creager, C., and Saucerman, S., 2004, Application of a linked water quality response model for establishing nutrient criteria for the California oak and chaparral sub-ecoregion in Proceedings of the Water Environment Federation, Watershed 2004: WEF, Session 21 through Session 30, p. 779-806.

*Fitch, Justin, 2008, Assessing wildfire risks at multiple spatial scales: Las Cruces, New Mexico State University, Master's thesis, 69 p., accessed March 4, 2011, at http://www.fs.fed.us/rm/pubs_other/rmrs_2008_fitch_j001.pdf.

*Fithian, Wayne; Peters, Albert; Viña, Andres; Ji, Lei; and Waltman, Bill, 2000, Development of a regionally based agronomic decision support system based upon remotely sensed and ancillary data: Waterloo, Nebr., Golden Harvest Seed and J.C. Robinson Seed Company, 20 p., accessed March 4, 2011, at http://leupold.gis.usu.edu/docs/data/nasa_arc/nasa_arc99/Reports/GoldenHa.pdf.

*Fletcher, J.J., Eli, R.N., Strager, M.P., Sun, Qingyun, Churchill, J.B., Lamont, S.J., Galya, T.A., and Schaer, A.N., 2004, The watershed characterization and modeling system (WCMS) - Support tools for large watershed CHIA and NPDES analyses in Advanced Integration of Geospatial Technologies in Mining and Reclamation, December 7 - 9, 2004, Atlanta, Ga., accessed March 7, 2011, at http://www.tips.osmre.gov/GeoSpatial/post-conference/Papers/Fletcher2_WV_FINAL.pdf.

*Ford, T.B., Winslow, D.E., Whitehead, D.R., and Koukol, M.A., 2001, Reproductive success of forestdependent songbirds near an agricultural corridor in south-central Indiana: Auk, v. 118, no. 4, p. 864-873.

*Forney, William; Raumann, Christian; Minor, T.B.; Smith, J.L.; Vogel, John; and Vitales, Robert, 2002, Land use change and effects on water quality and ecosystem health in the Lake Tahoe Basin, Nevada and California-Year-1 progress: Menlo Park, Calif., U.S. Geological Survey Open-File Report 02-014, 18 p.

Frame, J.D., 1983, Quantitative indicators for evaluation of basic research programs/projects: IEEE Transactions on Engineering Management, v. 30, no. 3, p. 106-112.

*Franklin, Janet, 2002, Enhancing a regional vegetation map with predictive models of dominant plant species in chaparral: Applied Vegetation Science, v. 5, no. 1, p. 135-146. 
*Fraser, R.H., 1998, Vertebrate species richness at the mesoscale-Relative roles of energy and heterogeneity: Global Ecology and Biogeography Letters, v. 7, no. 3, p. 215-220.

*Frescino, T.S., 1998, Development and validation of forest habitat models in the Uinta Mountains, Utah: Logan, Utah State University, Master's thesis, 75 p.

*Frescino, T.S., Edwards, T.C., and Moisen, G.G., 2001, Modeling spatially explicit forest structural attributes using generalized additive models: Journal of Vegetation Science, v. 12, no. 1, p. 15-26.

*Frizzelle, B.G., and Moody, Aaron, 2001, Mapping continuous distributions of land cover-A comparison of maximum-likelihood estimation and artificial neural networks: Photogrammetric Engineering \& Remote Sensing, v. 67, no. 6, p. 693-705.

*Fuller, M.M., Gross, L.J., Duke-Sylvester, S.M., and Palmer, Mark, 2008, Testing the robustness of management decisions to uncertainty-Everglades restoration scenarios: Ecological Applications, v. 18, no. 3, p. 711-723.

*Galavotti, Holly; Al-Mudallal, Amer; Miller, Robert; and Khan, Faruque, 2007, Appendix E. GIS summary for captan uses in Risks of capta use to federall threatened California red-legged frog (Rana aurora draytonii), 21 p., accessed March 3, 2011 at

http://citeseerx.ist.psu.edu/viewdoc/download?doi=10.1.1.168.6488\&rep $=$ rep $1 \&$ type $=p d f$.

*Galbraith, Hector, Smith, J.B., and Jones, Russell, 2006, Biodiversity changes and adaptation, in Smith, J.B., and Mendelsohn, R., eds., The impact of climate change on regional systems-A comprehensive analysis of California: Northampton, Mass., Edward Elgar, pp. 86-99.

Garfield, Eugene, 1994, The Thomson Reuters impact factor: Thomson Reuters (The Institute for Scientific Information ${ }^{\circledR}$ ), unpaged, accessed 6/14/2010, at

http://thomsonreuters.com/products_services/science/free/essays/impact_factor/.

Garfield, Eugene, 2001, Impact factors, and why they won't go away: Nature, v. 411, no. 6837, p. 522.

Garfield, Eugene, and Welljams-Dorof, Alfred, 1992, Citation data-Their use as quantitative indicators for science and technology evaluation and policy-making: Science and Public Policy, v. 19, no. 5, p. 321-327.

Garg, K.C., 2003, An overview of cross-national, national, and institutional assessment as reflected in the international journal Scientometrics: Scientometrics, v. 56, no. 2, p. 169-199.

Gauthier, Élaine, 1998, Bibliometric analysis of scientific and technological research-A user's guide to the methodology: Observatoire des Sciences et des Technologies (CIRST), Science and Technology Redesign Project, Statistics Canada, ST-98-08, 59 p.

Gavel, Ylva, and Iselid, Lars, 2008, Web of Science and Scopus-A journal title overlap study: Online Information Review, v. 32, no. 1, p. 8-21.

Genuis, S.K., 2005, Published literature and diffusion of medical innovation-Exploring innovation generation: Canadian Journal of Information and Library Sciences, v. 29, no. 1, p. 27-54.

*Germino, M.J., Reiners, W.A., Blasko, B.J., McLeod, Donald, and Bastian, C.T., 2001, Estimating visual properties of Rocky Mountain landscapes using GIS: Landscape and Urban Planning, v. 53, nos. 1-4, p. 71-83.

*Gerrard, R.A., Church, R.L., Stoms, D.M., and Davis, F.W., 1997, Selecting conservation reserves using species-covering models-Adapting the ARC/INFO GIS: Transactions in GIS, v. 2, no. 1, p. 45-60.

*Gillespie, T.W., 2005, Predicting woody-plant species richness in tropical dry forests-A case study from south Florida, USA: Ecological Applications, v. 15, no. 1, p. 27-37.

*Gitlin, A.R., Sthultz, C.M., Bowker, M.A., Stumpf, Stacy, Paxton, K.L., Kennedy, Karla, Munoz, Axhel, Bailey, J.K., and Whithan, T.G., 2006, Mortality gradients within and among dominant plant 
populations as barometers of ecosystem change during extreme drought: Conservation Biology, v. 20, no. 5, p. 1477-1486.

*Goebel, J.J., Schreuder, H.T., House, C.C., Geissler, P.H., Olsen, A.R., and Williams, William, 1998, A study on integrating surveys of terrestrial natural resources-The Oregon demonstration project: Corvallis, Oreg., U.S. Environmental Protection Agency, Office of Research and Development, National Health and Environmental Effects Research Laboratory, EPA/600/R-98/032, 44 p.

*Goheen, E.M., Hansen, E., Kanaskie, A., Osterbauer, N., Parke, J., Pscheidt, J., and Chastagner, G., 2006, Sudden Oak Death and Phytophthora ramorum - A guide for forest managers, Christmas tree growers, and forest-tree nursery operators in Oregon and Washington: Corvallis, Oregon State University Extension Service, accessed March 4, 2011, at http://www.oregonbeachsafety.org/ODF/privateforests/docs/fh/SODguide.pdf?ga $=t$.

*González, Grizelle, Gould, W.A., Hudak, A.T., and Hollingsworth, T.N., 2008, Decay of aspen (Populus tremuloides Michx.) wood in moist and dry boreal, temperate, and tropical forest fragments: Ambio, v. 37, no. 7, p. 588-597.

*Gonzalez-Rebeles, Carlos, Burke, V.J., Jennings, M.D., Ceballos, Gerardo, and Parker, N.C., 1998, Transnational gap analysis of the Rio Bravo/Rio Grande region: Photogrammetric Engineering \& Remote Sensing, v. 64, no. 11, p. 1115-1118.

*Gonzalez-Rebeles, Carlos, Thompson, B.C., and Bryant, F.C., 2002, Influence of selected environmental variables on GIS-habitat models used for gap analysis, in Scott, J.M., Heglund, P.J., Morrison, M.L., Haufler, J.B., Raphael, M.G., Wall, W.A., and Samson, F.B., eds., Predicting species occurrences-Issues of accuracy and scale: Washington, D.C., Island Press, p. 639-651.

*Good, R.E., Young, D.P., Jr., Eddy, J.P., 2002, Distribution of mountain plovers in the Powder River Basin, Wyoming: Cheyenne, Wyo.,Western EcoSystems Technology, Inc., unpublished manuscript, 13 p., accessed April 6, 2011, at http://www.west-inc.com/reports/blmmopl_report_final.pdf.

*Gori, D.F., and Enquist, C.A.F., 2003, An assessment of the spatial extent and condition of grasslands in central and southern Arizona, southwestern New Mexico and northern Mexico: Ariz., The Nature Conservancy Arizona Chapter, 28 p., accessed February 21, 2011, at http://www.nature.org/wherewework/northamerica/states/arizona/files/grassland_report.pdf.

*Gormanson, D.D., Aunan, T.J., Hansen, M.H., Hoppus, Michael, 2009, Exploring the association of the Minnesota Department of Natural Resources' satellite-detected change with the Forest Inventory and Analysis system of observed removals and mortality, in McRoberts, R.E., Reams, G.A., Van Deusen, P.C., McWilliams, W.H., eds., Eighth Annual Forest Inventory and Analysis Symposium, Monterey, Calif., October 16-19, 2006, Proceedings: Washington, D.C., U.S. Department of Agriculture Forest Service, General Technical Report WO-79, p. 251-258.

*Grand, Joanna, Buonaccorsi, John, Cushman, S.A., Griffin, C.R., and Neel, M.C., 2004, A multiscale landscape approach to predicting bird and moth rarity hotspots in a threatened pitch pine-scrub oak community: Conservation Biology, v. 18, no. 4, p. 1063-1077.

*Greenwald, D.N., and Bradley, Curtis, 2008, Assessing protection for imperiled species of Nevada, U.S.A.-Are species slipping through the cracks of existing protections?: Biodiversity and Conservation, v. 17, p. 2951-2960.

*Greenwood, D.L., 2006, Landscape analysis of tree mortality and pinyon-juniper woodland structure in the Great Basin: University of Nevada, Reno, Master's thesis, 85 p.

*Greenwood, D.L., and Weisberg, P.J., 2009, GIS-based modeling of pinyon-juniper woodland structure in the Great Basin: Forest Science, v. 55, no. 1, p. 1-12.

*Gregory, C.J., Carthy, R.R., and Pearlstine, L.G., 2006, Survey and monitoring of species at risk at Camp Blanding training site, northeastern Florida: Southeastern Naturalist, v. 5, no. 3, p. 473-498. 
*Gribb, W.J., Robinson, S.F., and Hamerlinck, J.D., 2001, Applying ArcView Spatial Analyst software's ModelBuilder to habitat conservation planning, in 2001 ESRI International User Conference, San Diego, Calif., Proceedings: Redlands, Calif., Environmental Systems Research Institute (ESRI), paper 788, accessed 2/28/2011, at http://proceedings.esri.com/library/userconf/proc01/professional/papers/pap 788/p788.htm.

*Grivet, Delphine, Sork, V.L., Westfall, R.D., and Davis, F.W., 2008, Conserving the evolutionary potential of California valley oak (Quercus lobata Née) - A multivariate genetic approach to conservation planning: Molecular Ecology, v. 17, no. 1, p. 139-156.

*Groves, C.R., Kutner, L.S., Stoms, D.M., Murray, M.P., Scott, J.M., Schafale, Michael, Weakley, A.S., and Pressey, R.L., 2000, Owning up to our responsibilities-Who owns lands important for biodiversity, in Stein, B.A., Kutner, L.S., and Adams, J.S., eds., Precious heritage-The status of biodiversity in the United States: New York, Oxford University Press, p. 275-300.

*Guerra, Marta; Walker, Edward; Jones, Carl; Paskewitz, Susan; Cortinas, M.R.; Stancil, Ashley; Beck, Louisa; Bobo, Matthew; and Kitron, Uriel, 2002, Predicting the risk of Lyme Disease-Habitat suitability for Ixodes scapularis in the north central United States: Emerging Infectious Diseases, v. 8, no. 3, p. 289-297.

*Guerry, A.D., and Hunter, M.L., Jr., 2002, Amphibian distributions in a landscape of forests and agriculture-An examination of landscape composition and configuration: Conservation Biology, v. 16, no. 3, p. 745-754.

*Gunter, J.T., Hodges, D.G., and Regens, J.L., 2005, Probability models for predicting local water quality regulations in the southern United States: Forest Policy and Economics, v. 7, no. 6, p. 868-876.

*Guo, Qinghua, Kelly, Maggi, and Graham, C.H., 2005, Support vector machines for predicting distribution of Sudden Oak Death in California: Ecological Modelling, v. 182, p. 75-90.

*Gustafson, E.J., Knutson, M.G., Niemi, G.J., and Friberg, Mary, 2002, Evaluation of spatial models to predict vulnerability of forest birds to brood parasitism by cowbirds: Ecological Applications, v. 12, no. 2, p. 412-426.

*Hagen, C.A., Pitman, J.C., Robel, R.J., Loughin, T.M., and Applegate, R.D., 2007, Niche partitioning by lesser prairie-chicken Tympanuchus pallidicinctus and ring-necked pheasant Phasianus colchicus in southwestern Kansas: Wildlife Biology, v. 13, suppl. 1, p. 34-41.

*Haight, R.G., Cleland, D.T., Hammer, R.B., Radeloff, V.C., and Rupp, T.S., 2004, Assessing fire risk in the wildland-urban interface: Journal of Forestry, v. 102, no. 7, p. 41-48.

*Haines, A.M., Leu, Matthias, Svancara, L.K., Wilson, Gina, and Scott, J.M., 2010, Using a distribution and conservation status weighted hotspot approach to identify areas in need of conservation action to benefit Idaho bird species: Northwest Science, v. 84, no. 1, p. 170-182.

**Halvorson, W.L., Thomas, K., Graham, L., Kunzmann, M.R., Bennett, P.S., Van Riper, C., and Drost, C., 2001, The Arizona Gap Analysis Project final report: Tucson, University of Arizona, U.S. Geological Survey Biological Resources Division, Western Ecological Research Center.

*Hamazaki, Toshihide, Boykin, K.G., and Thompson, B.C., 2001, Incorporating landscape context in conservation planning models for Fort Bliss Military Reservation, New Mexico and Texas: Las Cruces, New Mexico Cooperative Fish and Wildlife Research Unit, 62 p., accessed March 8, 2011, at http://fws-case12.nmsu.edu/kboykin/publications/Final\%20Fort\%20Bliss\%20Ecological\%20 Context.pdf.

*Hamazaki, Toshihide, Thompson, B.C., Locke, B.A., and Boykin, K.G., 2003, Analysis of ecological context for identifying vegetation and animal conservation planning foci-An example from the arid south-western USA: Journal of Environmental Planning and Management, v. 46, no. 2., p. 239-256. 
*Hamer Environmental, 2003, Analysis species assessment-Bald eagle (Haliaeetus leucocephalus) Relicense study T-4: Bellevue, Wash., Puget Sound Energy, unpublished manuscript, 21 p., accessed March 4, 2011, at https://www.pse.com/Hydro\%20Licensing/baker/reports/TerrestrialWGStudies/ T04\%20Analysis\%20Species/An_sp_lit_review_baldeagle_SN_Final_2_21_03.pdf.

*Hamer Environmental, 2003, Analysis species assessment-Common loon (Gavia immer), relicense study T-4: Bellevue, Wash., Puget Sound Energy, unpublished manuscript, 14 p., accessed March 3, 2011, at https://www.pse.com/Hydro\%20Licensing/baker/reports/TerrestrialWGStudies/ T04\%20Analysis\%20Species/An_sp_lit_review_loons_SN_Final_2_21_03.pdf.

*Hamer Environmental, 2003, Analysis species assessment-Mountain goat (Oreamnos americanus), relicense study T-4: Bellevue, Wash., Puget Sound Energy, unpublished manuscript, 17 p., accessed March 3, 2011, at http://www.pse.com/Hydro\%20Licensing/baker/reports/TerrestrialWGStudies/ T04\%20Analysis\%20Species/An_sp_lit_review_mtngoat_SN_FINAL_2_21_03.pdf.

*Hamer Environmental, 2003, Analysis species assessment-Northwestern salamander (Ambystoma gracile), relicense study T-4: Bellevue, Wash., Puget Sound Energy, unpublished manuscript, 18 p., accessed March 3, 2011, at http://uat.pse.com/Hydro\%20Licensing/baker/reports/TerrestrialWGStudies/T04\%20Analysis\%20 Species/An_sp_lit_review_nwsalamander_SN_Final_2_21_03.pdf.

*Hansen, M.H., and Wendt, D.G., 2000, Using classified Landsat Thematic Mapper data for stratification in a statewide forest inventory, in McRoberts, R.E., Reams, G.A., and Van Deusen, P.C., eds., First Annual Forest Inventory and Analysis Symposium, San Antonio, Tex., November 2-3, 1999, Proceedings: St. Paul, Minn., U.S. Department of Agriculture Forest Service, North Central Research Station, General Technical Report NC-213, p. 20-27.

*Hansen, S.K., Burk, T.E., Bolstad, P.V., and Schomaker, J.H., 1999, Construction of a geographic information system for wildlife refuge planning - Minnesota Valley National Wildlife Refuge: St. Paul, University of Minnesota, Department of Forest Resources, 16 p., accessed February 5, 2011, at http://www.gis.umn.edu/fws/ccp/mnv_summary.pdf.

*Hanser, S.E., and Huntly, N.J., 2006, The biogeography of small mammals of fragmented sagebrushsteppe landscapes: Journal of Mammalogy, v. 87, no. 6, p. 1165-1174.

*Hardison, Tanya, 2002, Application of GIS to modeling fire for vegetative restoration in northern Arizona: Denton, University of North Texas, Department of Geography, unpublished manuscript, 9 p., accessed January 30, 2011, at http://www.geog.unt.edu/ jminhe/Teaching/GIS-Inter/ TermProjects/TanyaHardison.pdf.

*Hardy, Dean, and Fowler, Laurie, 2009, Identifying and prioritizing potential conservation sites in the Upper Oconee subbasin, in Georgia Water Resources Conference, Athens, Ga., April 27-29, 2009, Proceedings: Athens, University of Georgia, Odum School of Ecology, p. 82-88.

*Harris, Stephanie, 2006, The contribution of environmental variables on small mammal species richness and relative abundance in eastern Nevada: University of Nevada, Las Vegas, Capstone paper, 26 p., accessed January 12, 2011, at http://digitalcommons.library.unlv.edu/thesesdissertations/300.

*Hartley, Dawn, and Aplet, G.H., 2001, Modeling wildlife habitat in the Greater Grand StaircaseEscalante ecosystem, in Fifth Biennial Conference of Research on the Colorado Plateau 1999, FRESC Report Series: U.S. Geological Survey, Southwest Biological Science Center, p. 173-183, accessed January 11,2011 , at http://sbsc.wr.usgs.gov/cprs/news_info/meetings/biennial/proceedings/1999/pdf/14_Hartley.pdf.

*Heathman, Gary, and Larose, Myriam, 2006, Modeling streamflow using SWAT with different soil and land cover geospatial data sets, in International Association of Science and Technology for 
Development Symposium, Environmental Modelling and Simulation Conference, St. Thomas, U.S. Virgin Islands, November 28-December 1, 2006, Proceedings: ACTA Press, Paper No. 556-025.

*Heathman, G.C., Larose, M., and Ascough, J.C., 2009, Soil and water assessment tool evaluation of soil and land use geographic information system data sets on simulated stream flow: Journal of Soil and Water Conservation, v. 64, no. 1, p. 17-32.

*Heaton, J.S., 2001, The LizLand model-Geomorphic landform and surface composition analysis of lizard habitat in the California Mojave Desert: Corvallis, Oregon State University, Doctoral dissertation, $117 \mathrm{p}$.

*Heaton, J.S., Kiester, A.R., and Meyers, S.M., 2006, LizLand-A geomorphic approach to lizard habitat modeling in the Mojave Desert: Journal of Arid Environments, v. 67, p. 202-225.

*Heller, J.A., Guertin, D.P., Miller, S.N., and Stone, J.J., 1999, GIS for watershed assessmentIntegrating spatial and tabular data to derive parameters for a hydrologic simulation model (ARDBSN), in 1999 ESRI User Conference, San Diego, Calif., Proceedings: Redlands, Calif., Environmental Systems Research Institute (ESRI), paper 368, accessed March 3, 2011, at http://proceedings.esri.com/library/userconf/proc99/proceed/papers/pap368/p368.htm.

*Hendricks, Paul; Kudray, G.M.; Lenard, Susan; and Maxell, Bryce, 2007, A multi-scale analysis linking prairie breeding birds to site and landscape factors including USGS GAP data-Report to the United States Department of the Interior, Bureau of Land Management, State Office: Helena, Montana Natural Heritage Program, 23 p.

**Henebry, G.M., Putz, B.C., Vaitkus, M.R., and Merchant, J.W., 2005, The Nebraska Gap Analysis Project final report: Lincoln, University of Nebraska-Lincoln, School of Natural Resources.

*Hepinstall, J.A., 2000, Creating spatially explicit predictions of bird presences in Maine-Evaluating input data, model performance, and model output: Orono, University of Maine, Doctoral dissertation, $165 \mathrm{p}$.

Herbstein, F.H., 1993, Measuring "publications output" and "publications impact" of faculty members of a university chemistry department: Scientometrics, v. 28, no. 3, p. 349-373.

*Herricks, E.E., Fisher, J.R.B., Kuehner, Curt, and Hovan, M.J., 2003, Application of GIS technologies to wildlife management at DFW airport in 5th Joint Annual Meeting Bird Strike Committee USA/Canada, Toronto, Ontario, August 18-21 2003, Proceedings: Lincoln, University of NebraskaLincoln, 11 p., accessed March 16, 2011, at http://digitalcommons.unl.edu/cgi/viewcontent.cgi? article $=1005 \&$ context $=$ birdstrike 2003 .

Hicks, Diana; Tomizawa, Hiroyuki; Saitoh, Yoshiko; and Kobayashi, Shinichi, 2004, Bibliometric techniques in the evaluation of federally funded research in the United States: Research Evaluation, v. 13 , no. 2 , p. $78-86$.

*Hoffman, J.D., and Choate, J.R., 2008, Distribution and status of the yellow-faced pocket gopher in Kansas: Western North American Naturalist, v. 68, no. 4, p. 483-492.

*Hoffman, J.D., Choate, J.R., and Channell, Rob, 2007, Effects of land use and soil texture on distributions of pocket gophers in Kansas: Southwestern Naturalist, v. 52, no. 2, p. 296-301.

*Hoffman, J.D., Narumalani, Sunil, Mishra, D.R., Merani, Paul, and Wilson, R.G., 2008, Predicting potential occurrence and spread of invasive plant species along the North Platte River, Nebraska: Invasive Plant Science and Management, v. 1, no. 4, p. 359-367.

*Homer, Collin; Dewitz, Jon; Fry, Joyce; Coan, Michael; Hossain, Nazmul; Larson, Charles; Herold, Nate; McKerrow, Alexa; VanDriel, J.N.; and Wickham, James, 2007, Completion of the 2001 National Land Cover Database for the conterminous United States: Photogrammetric Engineering \& Remote Sensing, v. 73, no. 4, p. 337-341. 
*Homer, Collin; Huang, Chengquan; Yang, Limin; Wylie, Bruce; and Coan, Michael, 2004, Development of a 2001 National Land Cover Database for the United States: Photogrammetric Engineering \& Remote Sensing, v. 70, no. 7, p. 829-840.

*Hopton, M.E., and Mayer, A.L., 2006, Using self-organizing maps to explore patterns in species richness and protection: Biodiversity and Conservation, v. 15, no. 14, p. 4477-4494.

*Howell, J.E., Peterson, J.T., and Conroy, M.J., 2008, Building hierarchical models of avian distributions for the state of Georgia: Journal of Wildlife Management, v. 72, no. 1, p. 168-178.

*Huang, C., Asner, G., Martin, R., Barger, N., and Neff, J., 2007, A cross-scale remote sensing approach to estimate tree cover and aboveground biomass in pinyon-juniper woodlands of the Colorado Plateau, USA, [abs.], in American Geophysical Union, 2007 AGU Fall meeting, San Francisco, Calif., December 10-14, 2007, Abstract \#B53B-1170: Washington, D.C., AGU, accessed March 29, 2011, at http://adsabs.harvard.edu/abs/2007AGUFM.B53B1170H.

*Huang, Chengquan; Homer, Collin; and Yang, Limin, 2003, Regional forest land cover characterisation using medium spatial resolution satellite data, chap. 14 of Wulder, M.A., and Franklin, S.E., eds., Remote sensing of forest environments - Concepts and case studies: Norwell, Mass., Kluwer Academic Publishers, p. 389-410.

*Huang, Chengquan; Yang, Limin; Homer, Collin; Coan, Michael; Rykhus, Russell; Zhang, Zheng; Wylie, Bruce; Hegge, Kent; Zhu, Zhiliang; Lister, Andrew; Hoppus, Michael; Tymcio, Ronald; DeBlander, Larry; Cooke, William; McRoberts, Ronald; Wendt, Daniel; and Weyermann, Dale, 2001, Synergistic use of FIA plot data and Landsat 7 ETM+ images for large area forest mapping, in McRoberts, R.E., Reams, G.A., Van Deusen, P.C., and Moser, J.W., eds., Third Annual Forest Inventory and Analysis Symposium, Traverse City, Mich., October 17-19, 2001, Proceedings: St. Paul, Minn., U.S. Department of Agriculture Forest Service, North Central Research Station, General Technical Report NC-230, p. 50-55.

*Huang, Cho-ying, Asner, G.P., Martin, R.E., Barger, N.N., and Neff, J.C., 2009, Multiscale analysis of tree cover and aboveground carbon stocks in pinyon-juniper woodlands: Ecological Applications, v. 19 , no. 3, p. 668-681.

*Huang, Cho-ying, and Geiger, E.L., 2008, Climate anomalies provide opportunities for large-scale mapping of non-native plant abundance in desert grasslands: Diversity and Distributions, v. 14, p. $875-884$.

*Hubbard, Brett, and Serfass, Tom, 2004, Assessing the distribution of reintroduced populations of river otters in Pennsylvania (USA) - Development of a landscape-level approach: IUCN Otter Specialist Group Bulletin, v. 21, no. 2, p. 60-65.

*Hubbard, M.W., Danielson, B.J., and Schmitz, R.A., 2000, Factors influencing the location of deervehicle accidents in Iowa: Journal of Wildlife Management, v. 64, no. 3, p. 707-713.

*Huber, P.R., Greco, S.E., and Thorne, J.H., 2010, Boundaries make a difference-The effects of spatial and temporal parameters on conservation planning: The Professional Geographer, v. 62, no. 3, p. 409-425, accessed March 17, 2011, at http://pdfserve.informaworld.com/511343_713582191_922020966.pdf.

*Hudak, P.F., and Sanmanee, Sirichai, 2003, Spatial patterns of nitrate, chloride, sulfate, and fluoride concentrations in the Woodbine Aquifer of North-Central Texas: Environmental Monitoring and Assessment, v. 82, p. 311-320.

*Hudak, P.F., and Wachal, D.J., 2001, Oil production, agriculture and groundwater quality in the southeastern Gulf Coast Aquifer, Texas: Environmental Monitoring and Assessment, v. 72, no. 3 , p. 249-264. 
*Hughes, T.W.; Shafer, Mark; Simonsen, Troy; Traurig, Jeremy; Mirsky, Nick; Stadler, S.J.; and Earls, P.G., 2002, Using environmental data to attract development-The Oklahoma wind power assessment initiative, reprinted from preprint volume, in Third Symposium on Environmental Applications, AMS Annual Meeting, Orlando, Fla., January 13-17, 2002: Boston, Mass., American Meteorological Society, accessed March 29, 2011, at http://cig.mesonet.org/staff/shafer/AMS\%20Final\%20Version\%20(100501).pdf.

*Hunter, J.C., Willett, K.B., McCoy, M.C., Quinn, J.F., and Keller, K.E., 1999, Prospects for preservation and restoration of riparian forests in the Sacramento Valley, California, USA: Environmental Management, v. 24, no. 1, p. 65-75.

*Hunter, L.M., Beal, John, and Dickinson, Thomas, 2003, Integrating demographic and GAP analysis biodiversity data-Useful insight?: Human Dimensions of Wildlife, v. 8, p. 145-157.

*Hunter, L.M., and Brehm, J.M., 2004, A qualitative examination of value orientations toward wildlife and biodiversity by rural residents of the intermountain region: Human Ecology Review, v. 11, no. 1, p. 13-26.

*Hurley, P.T., 2001, Conserving threatened habitat types in rural landscapes through land use planning-A case study in Wasco County, Oregon: Eugene, University of Oregon, Master's thesis, $177 \mathrm{p}$.

*Huryn, A.D., Butz Huryn, V.M., Arbuckle, C.J., and Tsomides, Leonidas, 2002, Catchment land-use, macroinvertebrates and detrius processing in headwater streams-Taxonomic richness versus function: Freshwater Biology, v. 47, no. 3, p. 401-415.

*Hychka, K.C., Wardrop, D.H., and Brooks, R.P., 2007, Enhancing a landscape assessment with intensive data-A case study in the Upper Juniata watershed: Wetlands, v. 27, no. 3, p. 446-461. Irvine, John; Martin, B.R.; Abraham, John; and Peacock, Tim., 1987, Assessing basic researchReappraisal and update of an evaluation of four radio astronomy observatories: Research Policy, v. 16, nos. 2-4, p. 213-227.

*Isaak, D.J., and Hubert, W.A., 2001a, A hypothesis about factors that affect maximum summer stream temperatures across montane landscapes: Journal of the American Water Resources Association, v. 37, no. 2, p. 351-366.

*Isaak, D.J., and Hubert, W.A., 2001b, Production of stream habitat gradients by montane watershedsHypothesis tests based on spatially explicit path analyses: Canadian Journal of Fisheries and Aquatic Science, v. 58, p. 1089-1103.

*Islas, C.G.R., 1996, A sensitivity test for species distribution models used for gap analysis in New Mexico: Lubbock, Texas Tech University, Doctoral dissertation, 145 p.

*Jacobs, B.F., Romme, W.H., and Allen, C.D., 2008, Mapping old versus young piñon-juniper stands with a predictive topo-climatic model in north-central New Mexico, USA: Ecological Applications, v. 18 , no. 7 , p. $1627-1641$.

*Janis, M.W., and Clark, J.D., 2002, Responses of Florida panthers to recreational deer and hog hunting: Journal of Wildlife Management, v. 66, no. 3, p. 839-848.

*Jantz, Patrick, and Goetz, Scott, 2008, Using widely available geospatial data sets to assess the influence of roads and buffers on habitat core areas and connectivity: Natural Areas Journal, v. 28, no. 3, p. 261-274.

*Jensen, Peter, and Preziosi, D.V., 2010, Using landscape connectivity to inform prioritization of restoration areas in the Delaware Estuary watershed [abs.], in 95th ESA annual meeting, Pittsburgh, Pa., August 1-6, 2010: Washington, D.C., Ecological Society of America, accessed March 3, 2011, at http://eco.confex.com/eco/2010/techprogram/P22166.HTM. 
*Jiang, Hong, Strittholt, J.R., Frost, P.A., and Slosser, N.C., 2004, The classification of late seral forests in the Pacific Northwest, USA, using Landsat ETM+ imagery: Remote Sensing and Environment, v. 91 , nos. $3-4$, p. 320-331.

*Jochimsen, D.M., 2005, Factors influencing the road mortality of snakes on the Upper Snake River Plain, Idaho, in Irwin, C.L., Garrett, P., and McDermott, K.P., eds., International Conference on Ecology and Transportation, Raleigh, N.C., 2005: Davis, Calif., Road Ecology Center, John Muir Institute of the Environment, University of California, Davis, p. 351-365, accessed March 8, 2011, at http://escholarship.org/uc/item/2rm731ww.

*Johnson, Adam, Truax, D.D., O'Hara, C.G., and Cartwright, John, 2002, Remote sensing, GIS, and land use and land cover mapping along the I-10 corridor in Pecora 15 and LandSatellite Information IV Conference, Denver, Colo., November 10-15, 2002: Mississippi State, Mississippi State University, 9 p., accessed March 14, 2011, at http://www.ncrste.msstate.edu/new/ncrste/publications/ conference/pecora/final_papers/pecora_9871_lulci10_johnson.pdf.

*Johnson, G.D., and Erickson, W.P., 2004, Analysis of potential wildlife/wind plant interactions, Bighorn site, Klickitat County, Washington: Cheyenne, Wyo., Western EcoSystems Technology, Inc., unpublished manuscript, 30 p., accessed April 6, 2011, at

http://wind.nrel.gov/public/library/johnson6.pdf.

*Johnson, J.H., Hamerlinck, J.D., and Gillham, J.H., 2001, An ArcView-based application for the management of noxious weed species in Wyoming, in 2001 ESRI International User Conference, San Diego, Calif., Proceedings: Redlands, Calif., Environmental Systems Research Institute (ESRI), paper 770, accessed March 7, 2011, at http://proceedings.esri.com/library/userconf/proc01/professional/papers/pap770/p770.htm.

*Johnston, D.M., 2003, The digital river basin-Interactive real-time visualization of landscape processes in International Symposium on Landscape Modeling, Anhalt University, Germany, Proceedings: accessed February 28, 2011, at http://www.masterla.de/conf/pdf/conf2003/64johnst.pdf.

*Johnston, James; Hartley, Steve; and Martucci, Antonio; 2000, Conservation and restoration of forested wetlands-New techniques and perspectives, in Hansen, M., and Burk, T., eds., Integrated tools for natural resources inventories in the 21st century: St. Paul, Minn., U.S. Department of Agriculture Forest Service, North Central Research Station, General Technical Report NC-212, p. 691-696.

*Johnston, Jimmy; Hartley, Steve; Martucci, Antonio; and Yantis, Brent, 1998, Louisiana wetland reserve program demonstration project, in 1998 ESRI International User Conference, San Diego, Calif., Proceedings: Redlands, Calif., Environmental Systems Research Institute (ESRI), paper 117, accessed January 14, 2011, at http://proceedings.esri.com/library/userconf/proc98/proceed/TO150/PAP117/P117.HTM.

*Jones, J.W., and Price, S.D., 2007, Conceptual design of the Everglades Depth Estimation Network (EDEN) grid: Reston, Va., U.S. Geological Survey Open-File Report 2007-1200, 20 p.

*Jovan, Sarah, and McCune, Bruce, 2005, Air-quality bioindication in the greater central valley of California, with epiphytic macrolichen communities: Ecological Applications, v. 15, no. 5, p. 1712-1726.

*Kanda, L.L., Fuller, T.K., Sievert, P.R., and Friedland, K.D., 2005, Variation in winter microclimate and its potential influence on Virginia opossum (Didelphis virginiana) survival in Amherst, Massachusetts: Urban Ecosystems, v. 8, p. 215-225.

*Kanda, L.L., Fuller, T.K., Sievert, P.R., and Kellogg, R.L., 2009, Seasonal source-sink dynamics at the edge of a species' range: Ecology, v. 90, no. 6, p. 1574-1585. 
*Karlik, J.F., 1998, Isoprene emission rate measurements and leafmass estimation for biogenic hydrocarbon emission inventories: University of California, Los Angeles, Doctoral dissertation, $184 \mathrm{p}$.

*Karlik, J.F., and Albertson E.D., 2002, Field Assessment of the Gap Analysis Program vegetation database in BVOC "Hotspots" in California [abs.]: American Geophysical Union, Fall meeting 2002, accessed March 21, 2011, at http://adsabs.harvard.edu/abs/2002AGUFM.B21A0709K.

*Karlik, J.F., Albertson, E.D., Chung, Y.J., McKay, A.H., and Winer, A.M., 2002, Field assessment of the California Gap Analysis Program GIS database in central California: Madroño, v. 49, no. 2, p. 99-114.

*Karlik, J.F., Chung, Y.J., and Winer, A.M., 2003, Biogenic emission inventory development—Field assessment of the GAP vegetation database in California: Physics and Chemistry of the Earth, v. 28, no. 8 , p. 315-325.

*Keehner, J.R., and Waits, L.P., 2006, Using DNA sequence analysis of hair and feces to detect and identify carnivore species in National Parks of the Southwest: McNair Research Journal, v. 2, p. 32-40, accessed March 16, 2011, at http://www.uiweb.uidaho.edu/mcnair/mcnair_journal/mcnair_journal_v02_2006.pdf\#page=41.

*Keinath, D.A., 2001, Habitat associations of Preble's meadow jumping mice in Wyoming-A GIS model and descriptive analysis: Laramie, Wyo., Wyoming Natural Diversity Database (WYNDD), University of Wyoming, unpublished manuscript, 18 p. accessed March 9, 2011, at http://www.uwyo.edu/wynddsupport/docs/Reports/WYNDDReports/U01KEI04WYUS.pdf.

*Kelley, Chris; Garson, Justin; Aggarwal, Anshu; and Sarkar, Sahotra, 2002, Place prioritization for biodiversity reserve network design-A comparison of the SITES and ResNet software packages for coverage and efficiency: Diversity and Distributions, v. 8, p. 297-306.

*Kepner, W.G., and Boykin, K.G., 2009, Modeling landscape-scale ecosystem services relative to biodiversity in the Upper San Pedro River Basin (U.S.-Mexico) [abs.], in Papers from the 2009 Annual Meeting of the Association of American Geographers, Las Vegas, Nev., March 22-27, 2009: Washington, D.C., Association of American Geographers, accessed July 31, 2010, at http://meridian.aag.org/callforpapers/program/AbstractDetail.cfm? AbstractID $=25500$.

*Kerns, R.R., Burk, T.E., Bolstad, P.V., and Schomaker, J.H., 2000, Construction of a geographic information system for wildlife refuge planning-Muscatautck National Wildlife Refuge: St. Paul, Minn., University of Minnesota Department of Forest Resources, Staff Paper Series No. 148, 16 p., accessed January 22, 2011, at http://www.forestry.umn.edu/prod/groups/cfans/@pub/@cfans/@forestry/documents/asset/cfans_ asset_184459.pdf.

*Kienast-Brown, S., and Boettinger, J.L., 2010, Applying the optimum index factor to multiple data types in soil survey, chap. 30 of Boettinger, J.L., Howell, D.W., Moore, A.C., Hartemink, A.E., and Kienast-Brown, S., eds., Digital Soil Mapping: New York, Springer, vol. 2., p. 385-398.

*Kiesow, A.M., 2003, Feasibility of reintroducing the river otter (Lontra canadensis) in South Dakota: Brookings, South Dakota State University, Master's thesis, 111 p., accessed March 7, 2011, at http://www.carnivoreconservation.org/files/thesis/kiesow_2003_msc.pdf.

*Kiester, A.R.; Scott, J.M.; Csuti, Blair; Noss, R.F.; Butterfield, Bart; Sahr, Kevin; and White, Denis, 1996, Conservation prioritization using GAP data: Conservation Biology, v. 10, no. 5, p. 1332-1342. *Kim, Jin-Woo; Lu, Zhong; Lee, Hyongki; Shum, C.K.; Swarzenski, C.M.; Doyle, T.W.; and Baek, Sang-Ho, 2009, Integrated analysis of PALSAR/Radarsat-1 InSAR and ENVISAT altimeter data for mapping of absolute water level changes in Louisiana wetlands: Remote Sensing of Environment, v. 113, p. 2356-2365. 
*King, D.T., and Michot, T.C., 2002, Distribution, abundance and habitat use of American white pelicans in the delta region of Mississippi and along the western Gulf of Mexico coast: Waterbirds, v. 25, no. 4, p. 410-416.

*Kirkpatrick, Chris, Conway, C.J., Hughes, K.M., and Devos, J.C. Jr., 2007, Probability of detecting band-tailed pigeons during call-broadcast versus auditory surveys: Journal of Wildlife Management, v. 71, no. 1, p. 231-237.

*Kleiner, Kevin; Vogt, Alison; Mackenzie, M.D.; and Grand, J.B., 2007, Developing a decision-support tool for longleaf pine conservation in the Southeast [abs.], in ESA/SER Joint Meeting, San Jose, Calif., August 5-10, 2007: Washington, D.C., Ecological Society of America/Society for Ecological Restoration International, accessed July 31, 2010, at http://eco.confex.com/eco/2007/techprogram/P1671.HTM.

*Kocovsky, P.M., and Carline, R.F., 2006, Influence of landscape-scale factors in limiting brook trout populations in Pennsylvania streams: Transactions of the American Fisheries Society, v. 135, no. 1, p. $76-88$.

*Kocovsky, P.M., Ross, R.M., Dropkin, D.S., and Campbell, J.M., 2008, Linking landscapes and habitat suitability scores for diadromous fish restoration in the Susquehanna River Basin: North American Journal of Fisheries Management, v. 28, no. 3, p. 906-918.

*Koenig, W.D., Krakauer, A.H., Monahan, W.B., Haydock, Joseph, Knops, J.M.H., and Carmen, W.J., 2009, Mast-producing trees and the geographical ecology of western scrub-jays: Ecography, v. 32, p. 561-570.

*Kohley, Thomas; Crist, Patrick; and Hamerlinck, Jeffrey, 1997, Applying Gap analysis data to land use planning and development of a bioinformation node [abs.], in 1997 ESRI International User Conference, San Diego, Calif., Proceedings: Redlands, Calif., Environmental Systems Research Institute (ESRI), accessed March 12, 2011, at http://proceedings.esri.com/library/userconf/proc97/proc97/abstract/a520.htm.

*Kostelnick, J.C., Peterson, D.L., Egbert, S.L., McNyset, K.M., and Cully, J.F., 2007, Ecological niche modeling of black-tailed prairie dog habitats in Kansas: Transactions of the Kansas Academy of Science, v. 110, no. 3., p. 187-200.

Kostoff, R.N., 1994, Quantitative/qualitative federal research impact evaluation practices:

Technological Forecasting and Social Change, v. 45, no. 2, p. 189-205.

Kostoff, R.N., 1995, Federal research impact assessment-Axioms, approaches, applications: Scientometrics, v. 34, no. 2, p. 163-206.

*Kretser, H.E., Sullivan, P.J., and Knuth, B.A., 2008, Housing density as an indicator of spatial patterns of reported human-wildlife interactions in northern NewYork: Landscape and Urban Planning, v. 84, nos. 3-4, p. 282-292.

*Kueppers, Lara; Riley, William; Jin, Jiming; Subin, Zack; Christianson, Danielle; and Torn, Margaret, 2009, Ecosystem feedbacks to climate change in California-Integrated climate forcing from vegetation redistribution: California Energy Commission, Public Interest Energy Research (PIER), CEC-500-2009-075, 34 p., accessed March 7, 2011, at http://www.energy.ca.gov/2009publications/CEC-500-2009-075/CEC-500-2009-075.PDF.

*Kuhn, T.J., Tate, K.W., Cao, David, and George, M.R., 2007, Juniper removal may not increase overall Klamath River Basin water yields: California Agriculture, v. 61, no. 4, p. 166-171.

*Kuhns, M.R., and Van Niel, T.G., 1996, Utah's private forest land characteristics: Logan, Utah State University, unpublished manuscript, 17 p., accessed March 11, 2011, at https://extension.usu.edu/forestry/UtahForests/Assets/PrivateForestCharacteristics.pdf. 
*Kunert, Kelly, 2005, A GIS approach to habitat restoration site selection and prioritization in the New York-New Jersey Harbor Estuary: Durham, N.C., Duke University, Master's thesis, 120 p.

*Kunzmann, M.R., Hobbs, R.J., Wallace, C.S.A., and Marsh, S.E., 1999, AVHRR imagery analysis and habitat modeling as planning tools for conducting yellow-billed cuckoo (Coccyzus americanus occidentalis) surveys in Arizona, in 1999 ESRI International User Conference, San Diego, Calif., Proceedings: Redlands, Calif., Environmental Systems Research Institute (ESRI), paper 361, accessed February 7, 2011, at http://proceedings.esri.com/library/userconf/proc99/proceed/papers/pap361/p361.htm.

*Kunzmann, M.R., Rybak, Alexander, and Bennett, P.S., 2000, Yellow-billed cuckoo (Coccyzus americanus occidentalis) habitat identification using GPS and GIS based survey information, in 2000 ESRI International User Conference, San Diego, Calif., Proceedings: Redlands, Calif., Environmental Systems Research Institute (ESRI), paper 429, accessed February 3, 2011, at http://proceedings.esri.com/library/userconf/proc00/professional/papers/pap429/p429.htm.

*Labiosa, William; Hearn, Paul; Strong, David; Bernknopf, Richard; Hogan, Dianna; and Pearlstine, Leonard, 2010, The south Florida ecosystem portfolio model—A web-enabled multicriteria land use planning decision support system: , in 43rd Hawaii International Conference on System Sciences (HICSS), Koloa, Kauai, Hawaii, January 5-8, 2010, Proceedings: HICSS, p. 1-10.

*LaBram, J.A., Peck, A.E., and Allen, C.R., 2007, Monitoring-based assessment of Gap-analysis models: Southeastern Naturalist, v. 6, no. 4, p. 633-656.

*Lambert, J.D., McFarland, K.P., Rimmer, C.C., and Faccio, S.D., 2000, Mountain Birdwatch 2000, Final report to the U.S. Fish and Wildlife Service: Woodstock, Vt., Vermont Institute of Natural Science, unpublished manuscript, 16 p., accessed March 7, 2011, at http://www.vtecostudies.org/PDF/MBW2000Report.pdf.

*Landis, J.D.; Monzon, J.P.; Reilly, Michael; and Cogan, Chris, 1998, Development and pilot application of the California Urban and Biodiversity Analysis (CURBA) model, in 1998 ESRI Users Conference, San Diego, Calif., Proceedings: Redlands, Calif., Environmental Systems Research Institute (ESRI), paper 571, accessed July 26, 2010, at http://proceedings.esri.com/library/userconf/proc98/proceed/to600/pap571/p571.htm\#N_1_.

*Landis, W.G., Ellis, J.A., Kaminski, L.A., and Markiewicz, A.J., 2009, Integration of ecological risk assessment and the GAP analysis program-Assessing risk to salmon in small streams: Bellingham, Western Washington University, Institute of Environmental Toxicology, 30 p., accessed January 11, 2011, at http://www.nbii.gov/images/uploaded/157450_1288640978373_GAPRRM_Program_Final_Report.pdf.

*Larrucea, E.S., and Brussard, P.F., 2008, Habitat selection and current distribution of the pygmy rabbit in Nevada and California, USA: Journal of Mammalogy, v. 89, no. 3, p. 691-699.

*Larson, B.D., and Sengupta, R.R., 2004, A spatial decision support system to identify species-specific critical habitats based on size and accessibility using US GAP data: Environmental Modelling \& Software, v. 19, p. 7-18.

*Laurent, E.J.; Shi, Haijin; Gatziolix, Demetrios; LeBouton, J.P.; Walters, M.B.; and Liu, Jianguo, 2005, Using the spatial and spectral precision of satellite imagery to predict wildlife occurrence patterns: Remote Sensing of Environment, v. 97, p. 249-262.

*Law, J.J., 2006, Conservation of vertebrate biodiversity in Texas - Setting priorities for reserve selection: Lubbock, Texas Tech University, Master's thesis, 123 p., accessed March 7, 2011, at http://etd.lib.ttu.edu/theses/available/etd-11272006-141232/unrestricted/Law_Jeffrey_Thesis.pdf. 
*Lee, Hyongki; Shum, C.K.; Yi, Yuchan; Ibaraki, Motomu; Kim, Jin-Woo; Braun, Alexander; Kuo, Chung-Yen.; and Lu, Zhong, 2009, Louisiana wetland water level monitoring using retracked TOPEX/POSEIDON altimetry: Marine Geodesy, v. 32, p. 284-302.

*LeGates, R., 2005, Teaching spatially integrated research methods, in 2005 Annual ESRI International User Group Conference, San Diego, Calif., Proceedings: Washington, D.C., Environmental Systems Research Institute (ESRI), paper 1009, accessed February 28, 2011, at http://proceedings.esri.com/library/userconf/proc05/papers/pap1009.pdf.

*Lenihan, J.M.; Drapek, Raymond; and Neilson, Ronald, 2006, Terrestrial ecosystem changes, chap. 5 of Smith, J.B., and Mendelsohn, Robert, eds., The impact of climate change on regional systems-A comprehensive analysis of California: Northampton, Mass., Edward Elgar, p. 60-85.

* Lennartz, Steven, 2005, Oregon forest land change mapping, in ASPRS Pecora 16 Conference, Sioux Falls, S. Dak., 2005, Proceedings: Bethesda, Md., American Society for Photogrammetry and Remote Sensing (ASPRS), 6 p., accessed January 11, 2011, at http://www.asprs.org/publications/proceedings/pecora16/Lennartz_S.pdf.

* Leu, Matthias, Hanser, S.E., and Knick, S.T., 2008a, Appendix A. Methods used to acquire and develop spatial data sets of anthropogenic features: Ecological Archives, unpaged, accessed August 2, 2010, at http://esapubs.org?Archive/appl/A018/039/appendix-A.htm.

*Leu, Matthias, Hanser, S.E., and Knick, S.T., 2008b, The human footprint in the West-A large-scale analysis of anthropogenic impacts: Ecological Applications, v. 18, no. 5, p. 1119-1139.

Leydesdorff, Loet, 2005, Evaluation of research and evolution of science indicators: Current Science, v. 89 , no. 9 , p. 1510-1517.

*Lin, J.P., Smith, R.D., and Kleiss, B.A., 2008, Using a multi-scale assessment of watershed integrity (MAWI) approach for establishing baseline conditions in watersheds: Vicksburg, Miss., U.S. Army Corps of Engineers, Engineer Research and Development Center, ERDC/EL TR-08-14, 60 p., accessed March 5, 2011, at http://handle.dtic.mil/100.2/ADA479141.

*Lindell, C.A., McCullough, D.G., Cappaert, David, Apostolou, N.M., and Roth, M.B., 2008, Factors influencing woodpecker predation on emerald ash borer: American Midland Naturalist, v. 159, p. 434-444.

*Lindsay, D.L., Bailey, Pamela, Lance, R.F,. Clifford, M.J., Delph, Robert, and Cobb, N.S., 2010, Effects of a nonnative, invasive lovegrass on Agave palmeri distribution, abundance, and insect pollinator communities: Vicksburg, Miss., U.S. Army Corps of Engineers, Engineer Research and Development Center, ERDC/EL TN-10-1, 18 p., accessed March 24, 2011, at http://dodreports.com/pdf/ada520830.pdf.

*Lipow, S.R., Vance-Borland, Kenneth, St. Clair, J.B., Henderson, Jan, and McCain, Cindy, 2004, Gap analysis of conserved genetic resources for forest trees: Conservation Biology, v. 18, no. 2, p. 412-423.

*Lipow, S.R., Vance-Borland, Kenneth, St. Clair, J.B., Henderson, J.A., and McCain, Cindy, 2007, In situ gene conservation of six conifers in western Washington and Oregon: Western Journal of Applied Forestry, v. 22, no. 3, p. 176-187.

*Liu, Shangbin; Cieszewski, C.J.; Lowe, Roger; and Zasada, Michal, 2009, Sensitivity analysis on longterm fiber supply simulations in Georgia: Southern Journal of Applied Forestry, v. 33, no.2, p. 81-90.

*Liu, Zhongwei, Volin, J.C., Owen, V.D., Pearlstine, L.G., Allen, J.R., Mazzotti, F.J., and Higer, A.L., 2009, Validation and ecosystem applications of the EDEN water-surface model for the Florida Everglades: Ecohydrology, v. 2, p. 182-194. 
*Logan, J.A., Régnière, J., Gray, D.R., and Munson, A.S., 2007, Risk assessment in the face of a changing environment - Gypsy moth and climate change in Utah: Ecological Applications, v. 17, no. 1, p. 101-117.

*Lomolino, M.V., and Smith, G.A., 2001, Dynamic biogeography of prairie dog (Cynomys ludovicianus) towns near the edge of their range: Journal of Mammalogy, v. 82, no. 4, p. 937-945.

*Lopez, R.D., Nash, M.S., Heggem, D.T., and Ebert, D.W., 2008, Watershed vulnerability predictions for the Ozarks using landscape models: Journal of Environmental Quality, v. 37, p. 1769-1780.

*Love, J.W., and May, E.B., 2007, Relationships between fish assemblage structure and selected environmental factors in Maryland's coastal bays: Northeastern Naturalist, v. 14, no. 2, p. 251-268.

*Lowe, R.C.; Cieszewski, C.J.; Liu, Shangbin; Meng, Qingmin; Siry, J.P.; Zasada, Michał; and Zawadzki, Jaroslaw, 2009, Assessment of stream management zones and road beautifying buffers in Georgia based on remote sensing and various ground inventory data: Southern Journal of Applied Forestry, v. 33, no. 2, p. 91-100.

*Lowe, Tripp, Cieszewski, C.J., Zasada, Michal, and Zawadzki, Jarek, 2005, Distributing FIA information onto segmented Landsat Thematic Mapper images stratified with industrial ground data, in McRoberts, R.E., Reams, G.A., Van Deusen, P.C., McWilliams, W.H., and Cieszewski, C.J., eds., Fourth Annual Forest Inventory and Analysis Symposium, New Orleans, La., November 19-21, 2002, Proceedings: St. Paul, Minn., U.S. Department of Agriculture, Forest Service, North Central Research Station, General Technical Report NC-252, p. 111-116.

*Lowry, J.H., Jr., Langs, L.A., Ramsey, R.D., Kirby, Jessica, and Schulz, Keith, 2007, A matrix-based approach to fuzzy set accuracy assessment-RS/GIS Lab white paper: Logan, Utah State University, Remote Sensing/GIS Laboratory, unpublished manuscript, 23 p., accessed March 4, 2011, at http://earth.gis.usu.edu/swgap/data/RSGIS_WhitePaper_2007_Matrix-based_approach_to_fuzzy_ set_accuracy_assessment.pdf.

*Luce, Alan, 2004, Sagebrush change detection: Logan, Utah State University, unpublished manuscript, 24 p., accessed March 4, 2011, at http://www.gis.usu.edu/ doug/RS5750/PastProj/FA2004/AlanLuce.pdf.

*Lyon, P., 2005a, Colorado plateau mixed low sagebrush shrubland: unpublished manuscript, accessed February 3, 2011, at http://conserveonline.org/workspaces/CO\%20$\% 20$ San\%20Juan\%20Project/SanJuanPhase2Report/Appendix2/CPMixedLowSagebrushSystemGuid eline.doc.

*Lyon, P., 2005b, Intermountain basin semi-desert shrub steppe system guideline: unpublished manuscript, accessed January 15, 2011, at http://conserveonline.org/workspaces/CO\%20$\% 20$ San\%20Juan\%20Project/SanJuanPhase2Report/Appendix2/InterMountainBasinsSemiDesertShr ubSteppeSystem Guideline.doc.

*Lyon, P., 2005c, Inter-mountain basins Greasewood Flat: unpublished manuscript, accessed January 17, 2011, at http://conserveonline.org/workspaces/CO\%20$\% 20$ San\%20Juan\%20Project/SanJuanPhase2Report/Appendix2/InterMountainBasinsGreasewoodFl atSystem Guideline.doc.

*Lyon, P., 2005d, Inter-mountain basins mat saltbush shrubland: unpublished manuscript, accessed March 29, 2011, at http://conserveonline.org/workspaces/CO\%20-\%20San\%20Juan\%20Project/ SanJuanPhase2Report/Appendix2/InterMountainBasinsMatSaltbushShrublandSystemGuideline.doc. *Lyon, P., 2005e, Inter-mountain basins Shale Badlands: unpublished manuscript, accessed March 29, 2011, at http://conserveonline.org/workspaces/CO\%20-\%20San\%20Juan\%20Project/ SanJuanPhase2Report/Appendix2/InterMountainBasinsShaleBadlandsSystemGuideline.doc. 
*MacEwen, Rebecca; Mann, R.S.; Heilman, Philip; Stone, Jeffry; Castillo, A.M.; and Guertin, D.P., 2005, Defining boundaries across borders - A case study extending a major land resource area into Mexico in Gottfried, G.J., Gebow, B.S., Eskew, L.G., Edminster, C.B., comps., Connecting mountain islands and desert seas - Biodiversity and management of the Madrean Archipelago II, Proceedings: Fort Collins, Colo., U.S. Department of Agriculture Forest Service, Rocky Mountain Research Station, RMRS-P-36, p. 525-528.

*MacQueen, A.A., 2005, Spatial characterization of pollution sources - An analysis of in-stream water quality data from the Potomac headwaters of West Virginia: Morgantown, West Virginia University, Master's thesis, 113 p., accessed March 8, 2011, at http://wvuscholar.wvu.edu:8881//exlibris/dtl/d3_1/ apache_media/L2V4bGlicmlzL2R0bC9kM18xL2FwYWNoZV9tZWRpYS83MzI4.pdf.

*Mahan, C.G., Bishop, J.A., Steele, M.A., Turner, Gregory, and Myers, W.L., 2010, Habitat characteristics and revised gap landscape analysis for the northern flying squirrel (Glaucomys sabrinus), a state endangered species in Pennsylvania: American Midland Naturalist, v. 164, no. 2, p. 283-295.

*Mahan, C.G., and O'Connell, T.J., 2005, Small mammal use of suburban and urban parks in central Pennsylvania: Northeastern Naturalist, v. 12, no. 3, p. 307-314.

*Mangiameli, John, 1999, Citizen-initiated conservation planning and GIS, in 1999 ESRI International User Conference, San Diego, Calif., Proceedings: Washington, D.C., Environmental Systems Research Institute (ESRI), paper 174, accessed March 5, 2011, at http://proceedings.esri.com/library/userconf/proc99/proceed/papers/pap174/p174.htm.

*Manier, D.J., Hobbs, N.T., Theobald, D.M., Reich, R.M., Kalkhan, M.A., and Campbell, M.R., 2005, Canopy dynamics and human caused disturbance on a semi-arid landscape in the Rocky Mountains, USA: Landscape Ecology, v. 20, p. 1-17.

*Mansell, Gerard, and Hoats, Abby, 2005, Development of current year GIS databases for air quality and emission inventory development and analysis for the WRAP: Novato, Calif., ENVIRON International Corporation, unpublished manuscript, 87 p., accessed March 12, 2011, at http://wrapair.org/forums/toc/documents/GIS/GIS_Update_FinalReport_072905.pdf.

*Mark, Walter, and Jirka, Amy, 2002, Surveying for Sudden Oak Death in California, in Standiford, R.B., McCreary, Douglas, Purcell, K.L., eds., Fifth Symposium on Oak Woodlands-Oaks in California's changing landscape, San Diego, Calif., October 22-25, 2001, Proceedings: Albany, Calif., U.S. Department of Agriculture Forest Service, Pacific Southwest Research Station, General Technical Report PSW-GTR-184, p. 819a-823a.

*Marshall, C.H., Pielke, R.A., Sr., Steyaert, L.T., and Willard, D.A., 2004, The impact of anthropogenic land-cover change on the Florida peninsula sea breezes and warm season sensible weather: Monthly Weather Review, v. 132, p. 28-52.

*Martin, August, Gunter, J.T., and Regens, J.L., 2003, Estimating erosion in a riverine watershedBayou Liberty-Tchefuncta River in Louisiana: Environmental Science and Pollution Research, v. 10, no. 4, p. 245-250.

Martin, B.R., 1996, The use of multiple indicators in the assessment of basic research: Scientometrics, v. 36, no. 3, p. 343-362.

Martin, B.R., and Irvine, J., 1983, Assessing basic research-Some partial indicators of scientific progress in radio astronomy: Research Policy, v. 12, no. 2, p. 61-90.

*Martin, D.J., White, G.C., and Pusateri, F.M., 2007, Occupancy rates by swift foxes (Vulpes velox) in eastern Colorado: Southwestern Naturalist, v. 52, no. 4, p. 541-551.

* Martin, M.S., 2008, Herpetofaunal species richness of a longleaf pine (Pinus palustris) restoration site in Wake County, North Carolina: Raleigh, North Carolina State University, Master's thesis, 59 p., 
accessed March 5, 2011, at

http://repository2.lib.ncsu.edu/dr/bitstream/1840.4/1985/1/MartinMichael+final.pdf.

*Martin, Rene, Kruger, Lia, and Zablotney, Joetta, 2003, Final report-Amphibian surveys in the Baker River Hydroelectric project area (Baker River project relicense study T17): Bellevue, Wash., Puget Sound Energy, unpublished manuscript, 99 p., accessed March 7, 2011, at http://uat.pse.com/Hydro\%20Licensing/baker/reports/TerrestrialWGStudies/T17\%20Amphibian\%20S tudy/T17_Final_Amphibian_Report_10_27_03.pdf.

*Martinez, L.A., and Penland, Shea, 2009, Land cover changes of the Lake Ponchartrain Basin-19822005: Journal of Coastal Research, v. 54, p. 37-47.

*Martinuzzi, Sebastian, Vierling, L.A., Gould, W.A., Vierling, K.T., and Hudak, A.T., 2009, Incorporating remotely sensed tree canopy cover data into broad scale assessments of wildlife habitat distribution and conservation: Journal of Applied Remote Sensing, v. 3, 17 p., accessed January 10, 2011, at http://www.fs.fed.us/global/iitf/pubs/ja_iitf_2009_martinuzzi004.pdf.

*Matocq, M.D., and Murphy, P.J., 2007, Fine-scale phenotypic change across a species transition zone in the genus Neotoma-Disentangling independent evolution from phylogenetic history: Evolution, v. 61 , no. 11, p. $2544-2557$.

*Mattice, J.A., Brauning, D.W., and Diefenbach, D.R., 2005, Abundance of grassland sparrows on reclaimed surface mines in western Pennsylvania, in Ralph, C.J., and Rich, T.D., eds., Bird conservation implementation and integration in the Americas, Third International Partners in Flight Conference, Asilomar, Calif., March 20-24, 2002, Proceedings, v. 1: Albany, Calif., U.S. Department of Agriculture Forest Service, Pacific Southwest Research Station, General Technical Report PSWGTR-191, p. 504-510.

*Mau-Crimmins, Theresa, de Steiguer, J.E., and Dennis, Donald, 2005, AHP as a means for improving public participation-A pre-post experiment with university students: Forest Policy and Economics, v. 7, no. 4, 501-514.

*Mau-Crimmins, Theresa, and Liberti, Leslie, 2002, Combined integer goal programming and analytic hierarchy process approach for nature reserve design-A southern Arizona case study, in Symposium on Models and Systems in Forestry, Chile, 2002: accessed March 4, 2011, at http://www.dii.uchile.cl/ sympfor/CD/files/papers/area04/maucrimmins.pdf.

*Mawdsley, J.R., 2001a, Ecology, biogeography, and conservation of checkered beetles (Insecta: Coleoptera: Cleridae) in southeastern Arizona-A geographic information system (GIS) study: Transactions of the American Entomological Society, v. 127, no. 3, p. 431-449.

*Mawdsley, J.R., 2001b, Taxonomy, phylogeny, and biogeography of the genus Asydates Casey (Insecta: Coleopter: Melyridae): Insecta Mundi, v. 15, no. 2, p. 123-128.

*Maxwell, S.K., Hoffer, R.M. and Chapman, P.L., 2002, AVHRR composite period selection for land cover classification: International Journal of Remote Sensing, v. 23, no. 23, p. 5043-5059.

*McCarthy, S.B., 1998, Arizona terrestrial vertebrate species richness-An application of Arizona GAP GIS thematic processing: Tucson, University of Arizona, Master's thesis, $86 \mathrm{p}$.

*McClain, B.J., and Porter, W.F., 2000, Using satellite imagery to assess large-scale habitat characteristics of Adirondack Park, New York, USA: Environmental Management, v. 26, no. 5, p. 553-561.

*McConnell, Scott, O'Connell, T.J., and Leslie, D.M., Jr., 2008, Land cover associations of nesting territories of three sympatric Buteos in shortgrass prairie: Wilson Journal of Ornithology, v. 120, no. 4 , p. $708-716$.

*McCord, John; Drellack, S.L.; Ruskauff, Greg; Farnham, Irene; Fryer, William; Montazer, Perry; Pickens, John; Brooks, Keely; Bryant, Nathan; Miller, Christie; Rose, Janice; and Sanchez, Jeff; 2006, 
Phase I hydrologic data for the groundwater flow and contaminant transport model of corrective action unit 97-Yucca Flat/Climax Mine, Nevada test site, Nye County, Nevada: Las Vegas, Nev., Stoller-Navarro Joint Venture, 643 p., accessed February 7, 2011, at http://www.osti.gov/energycitations/servlets/purl/892000-OX3Ije/892000.pdf.

*McCoy, M.C., Quinn, J.F., and Kalman, Naomi, 2002, Identifying environmental and agricultural values and opportunities for regional planning - A GIS approach, prepared for the Sacramento Council of Governments: Davis, University of California, Davis, Information Center for the Environment, unpaged, accessed February 24, 2011, at http://www.ice.ucdavis.edu/sacog/mccoy_environmental_paper.doc.

*McKerrow, A.J., 2007, Mapping and monitoring plant communities in the coastal plain of North Carolina-A basis for conservation planning: Raleigh, North Carolina State University, Doctoral dissertation, $196 \mathrm{p}$.

*McKerrow, Alexa; Terando, Adam; and Frost, Cecil, 2007, Using the Gap Analysis Project land cover to map potential restoration sites within th erange of Longleaf pine (Pinus palustris) [abs.], in ESA/SER Joint Meeting, San Jose, Calif., August 5-10, 2007: Washington, D.C., Ecological Society of America/Society for Ecological Restoration International, accessed March 2, 2011, at http://eco.confex.com/eco/2007/techprogram/P1670.HTM.

*Meentemeyer, Ross; Rizzo, David; Mark, Walter; and Lotz, Elizabeth, 2004, Mapping the risk of establishment and spread of Sudden Oak Death in California: Forest Ecology and Management, v. 200, p. 195-214.

*Mehaffey, Megan; Tankersley, Roger, Jr.; Miller, Latoya; and Smith, Elizabeth, 2009, Evaluating habitat vulnerability to hazardous air pollutants in the southeastern United States: Integrated Environmental Assessment and Management, v. 5, no. 1, p. 150-157.

Melkers, Julia, 1993, Bibliometrics as a tool for analysis of R\&D impacts, chap. 3 of Bozeman, B., and Melkers, J., eds., Evaluating R\&D impacts-Methods and practice: Boston, Mass., Kluwer, p. $43-61$. *Menakis, J.P., Miller, Melanie, and Thompson, Thomas, 2004, Mapping relative fire regime condition class for the Western United States, in Greer, J.D_- ed., Remote sensing for field users-Proceedings of the Tenth Forest Service Remote Sensing Applications Conference, Salt Lake City, Utah, April 59, 2004: Bethesda, Md., American Society of Photogrammetry and Remote Sensing, accessed March 23, 2011, at http://www.fs.fed.us/rm/pubs_other/rmrs_2004_menakis001.pdf.

*Menking, K.M., Anderson, R.Y., Shafike, N.G, Syed, K.H., and Allen, B.D., 2004, Wetter or colder during the Last Glacial Maximum? Revisiting the pluvial lake question in southwestern North America: Quaternary Research, v. 62, no. 3, p. 280-288.

*Menking, K.M., Syed, K.H., Anderson, R.Y., Shafike, N.G., and Arnold, J.G., 2003, Model estimates of runoff in the closed, semiarid Estancia basin, central New Mexico, USA: Hydrological Sciences Journal, v. 48, no. 6, p. 953-970.

*Menzel, J.M., Ford, W.M., Edwards, J.W., and Ceperley, L.J., 2006, A habitat model for the Virginia northern flying squirrel (Glaucomys sabrinus fuscus) in the central Appalachian Mountains: Newtown Square, Pa., U.S. Department of Agriculture Forest Service, Northeastern Research Station, Research Paper NE-729, 10 p., accessed March 16, 2011, at

http://www.fs.fed.us/ne/newtown_square/publications/research_papers/pdfs/2006/ne_rp729.pdf.

*Merrill, Troy, Wright, R.G., and Scott, J.M., 1995, Using ecological criteria to evaluate wilderness planning options in Idaho: Environmental Management, v. 19, no. 6, p. 815-825.

*Meyer, W.D., Balbach, H.E., and Berner, J.T., 2007, Existing geospatial knowledge of gopher tortoise population and abundance: Champaign, Ill., U.S. Army Corps of Engineers, Engineer Research and 
Development Center, ERDC/CERL SR-075, 44 p., accessed March 5, 2011, at http://www.dtic.mil/cgi-bin/GetTRDoc? AD=ADA473829\&Location=U2\&doc=GetTRDoc.pdf.

*Millar, C.I., King, J.C., Westfall, R.D., Alden, H.A., and Delany, D.L., 2006, Late holocene forest dynamics, volcanism, and climate change at Whitewing Mountain and San Joaquin Ridge, Mono County, Sierra Nevada, CA, USA: Quaternary Research, v. 66, p. 273-287.

*Miller, S.J., Wardrop, D.H., Mahaney, W.M., and Brooks, R.P., 2006. A plant-based index of biotic integrity (IBI) for headwater wetlands in central Pennsylvania: Ecological Indicators, v. 6, no. 2, p. 290-312.

**Minnesota Department of Natural Resources [MDNR \}, 2007a, GAP land cover metadata.

*Mitchell, J.E., and Roberts, T.C., Jr., 1999, Distribution of pinyon-juniper in the western United States, in Monsen, S.B., Stevens, Richard, comps., Ecology and management of pinyon-juniper communities within the Interior West, Provo, Utah, September 15-18, 1999, Proceedings: Fort Collins, Colo., U.S. Department of Agriculture Forest Service, Rocky Mountain Research Station, RMRS-P-9, p. $146-154$.

Moed, H.F., 2009, New developments in the use of citation analysis in research evaluation: Archivum Immunologiae et Therapiae Experimentalis, v. 57, no. 1, p. 13-18.

*Moen, Ron, Burdett, C.L., and Niemi, G.J., 2008, Movement and habitat use of Canada lynx during denning in Minnesota: Journal of Wildlife Management, v. 72, no. 7, p. 1507-1513.

*Moen, Ronald, Niemi, Gerald, and Burdett, C.L., 2008, Canada lynx in the Great Lakes region: Duluth, University of Minnesota, Center for Water and Environment, Natural Resources Research Institute, NRRI Technical Report No. NRRI/TR-2008-14 Release 1.1, 48 p., accessed March 7, 2011, at http://www.nrri.umn.edu/lynx/publications/Moen_etal_NRRI_TR_2008_14_.pdf.

*Moisen, G.G., Thomas, C.E., Jr. and van Hooser, Dwane, 1998, Merging regional forest inventory data with satellite-based information through non linear regression methods, in Second Conference on Fusion of Earth Data-Merging Point Measurements, Raster Maps and Remotely Sensed Images, Sophia, Antipolis, France, January 28-30, 1998, Proceedings: Nice, France, SEE/URISCA, p. 123-128, accessed February 26, 2011, at http://www.fs.fed.us/ne/rsb/france98.ps.

*Monahan, W.B., and Koenig, W.D., 2006, Estimating the potential effects of Sudden Oak Death on oak-dependent birds: Biological Conservation, v. 127, p. 146-157.

*Monahan, W.B. and Koenig, W.D., 2007, Potential effects of Sudden Oak Death on the oak woodland bird community of coastal California, in Frankel, S.J., Shea, P.J., and Haverty, M.I., tech. coords., Sudden Oak Death Second Science Symposium - The state of our knowledge, Proceedings: Albany, Calif., U.S. Department of Agriculture Forest Service, Pacific Southwest Research Station, General Technical Report PSW-GTR-196, p. 195-209.

*Moody, A.T.; Grand, J.B.; Collazo, Jaime; Jones, Tim; and Watson, Craig, 2010, Designing landscapes for sustainable bird populations in the Southeastern United States [abs.], in The 95th ESA Annual Meeting, Pittsburgh, Penn., August 1-6, 2010: Washington, D.C., Ecological Society of America, accessed March 3, 2011, at http:/leco.confex.com/eco/2010/techprogram/P24619.HTM.

*Morin, Doug, 2007, Land conservation and water quality in the Saratoga Lake watershed: Saratoga Springs, N.Y., Skidmore College, Capstone paper, accessed February 28, 2011, at http://www.skidmore.edu/academics/wri/morin.pdf.

*Moritz, M.A., Keeley, J.E., Johnson, E.A., and Schaffner, A.A., 2004, Testing a basic assumption of shrubland fire management-How important is fuel age?: Frontiers in Ecology and the Environment, v. 2 , no. 2, p. 67-72.

*Moritz, M.A., and Odion, D.C., 2005, Examining the strength and possible causes of the relationship between fire history and Sudden Oak Death: Oecologica, v. 144, p. 106-114. 
*Moritz, M.A., and Odion, D.C., 2006, Examining the relationship between fire history and Sudden Oak Death patterns - A case study in Sonoma County, in Frankel, S.J., Shea, P.J., and Haverty, M.I., tech. coords., Sudden Oak Death Second Science Symposium-The state of our knowledge, Proceedings: Albany, Calif., U.S. Department of Agriculture Forest Service, Pacific Southwest Research Station, General Technical Report PSW-GTR-196, p. 169-177.

*Moritz, M.A., Stoms, D.M., Borchert, M.I., and Davis, F.W., 1997, A proposed protocol for identifying potential research natural areas with Gap Analysis data, in 1997 ESRI User Conference, San Diego, Calif., Proceedings: Redlands, Calif., Environmental Systems Research Institute (ESRI), paper 145, accessed March 3, 2011, at http://proceedings.esri.com/library/userconf/proc97/proc97/to150/pap145/p145.htm.

*Morrison, J.L., and Humphrey, S.R., 2001, Conservation value of private lands for Crested Caracaras in Florida: Conservation Biology, v. 15, p. 675-684.

*Morrison, P.H, Karl, J.W., Harma, K.J., Swope, Lindsey, Allen, T.K., and Becwar, Pamela, 2000, Assessment of summer 2000 wildfires - Landscape history, current condition and ownership: Winthrop, Wash., Pacific Biodiversity Institute, 80 p., accessed March 7, 2011, at http://www.landsinfo.org/ecosystem_defense/Resources_Species_Topics/Fire/wildfire2000.pdf.

Mullins, N.C., 1987, Evaluating research programs-Measurement and data sources: Science and Public Policy, v. 14, no. 2, p. 91-98.

*Munson, A.B., and Delfino, J.J., 2007, Minimum wet-season flows and levels in southwest Florida rivers: JAWRA Journal of the American Water Resources Association, v. 43, no. 2, p. 522-532.

*Murphy, D.D., 1999, Southern california natural community conservation planning - Case study, in Johnson, K.N., ed., Bioregional assessments - Science at the crossroads of management and policy: Washington, D.C., Island Press, p. 231-245.

*Murphy, H.T., and Lovett-Doust, Jon, 2007, Accounting for regional niche variation in habitat suitability models: Oikos, v. 116, p. 99-110.

*Murray, L.D., and Best, L.B., 2003, Short-term bird response to harvesting switchgrass for biomass in Iowa: Journal of Wildlife Management, v. 67, no. 3, p. 611-621.

*Murray, Michael, 2005, Our threatened timberlines-The plight of whitebark pine ecosystems: Kalmiopsis, v. 12, p. 25-29, accessed March 8, 2011, at http://www.whitebarkfound.org/Am2009/Murray\%20WBP\%20Kalmiopsis.pdf.

*Myers, W.L., 2006, Surface structures and tiered topography: Environmetrics, v. 17, p. 591-603. Narin, Francis, 1987, Bibliometric techniques in the evaluation of research programs: Science and Public Policy, v. 14, no. 2, p. 99-106.

Narin, F., and Hamilton, K.S., 1996, Bibliometric performance measures: Scientometrics, v. 36, no. 3, p. 293-310.

Narin, Francis; Olivastro, Dominic; and Stevens, K.A., 1994, Bibliometrics-Theory, practice, and problems: Evaluation Review, v. 18, no. 1, p. 65-76.

*Naugle, D.E., Higgins, K.F., Estey, M.E., Johnson, R.R., and Nusser, S.M., 2000, Local and landscape-level factors influencing black tern habitat suitability: Journal of Wildlife Management, v. 64 , no. 1, p. $253-260$.

*Naugle, D.E., Higgins, K.F., Nusser, S.M., and Johnson, W.C., 1999, Scale dependent habitat use in three species of prairie wetland birds: Landscape Ecology, v. 14, p. 267-276.

*Naugle, D.E., Johnson, R.R., Estey, M.E., and Higgins, K.F., 2001, A landscape approach to conserving wetland bird habitat in the prairie pothole region of eastern South Dakota: Wetlands, v. 21, no. 1, p. $1-17$. 
*Neely, Betsy; Comer, Pat; Moritz, Cherie; Lammert, Mary; Rondeau, Renee; Pague, Chris; Bell, Gary; Copeland, Holly; Humke, John; Spackman, Susan; Schulz, Terri; Theobald, David; and Valutis, Laura, 2001, Southern Rocky Mountains-An ecoregional assessment and conservation blueprint: The Nature Conservancy [with support from the U.S. Department of Agriculture Forest Service, Rocky Mountain Region, Colorado Division of Wildlife, and U.S. Department of the Interior Bureau of Land Management], 754 p., accessed March 8, 2011, at http://azconservation.org/dl/TNCAZ_Ecoregions_Assessment_Southern_Rocky_Mtns.pdf.

*Nelson, M.D., Johnson, D.H., Linkhart, B.D., and Miles, P.D., 2009, Flammulated owl (Otus flammeolus) breeding habitat abundance in ponderosa pine forests of the United States, in Rich, T.D., ed., Tundra to Tropics - Connecting Birds, Habitats, and People, Fourth International Partners in Flight Conference, McAllen, Tex., February 13-16, 2008, Proceedings: St. Paul, Minn., U.S. Department of Agriculture Forest Service, Northern Research Station, p. 71-81, accessed March 2, 2011, at http://www.nrs.fs.fed.us/pubs/jrnl/2009/nrs_2009_nelson_003.pdf.

*Nesslage, G.M., Maurer, B.A., and Gage, S.H., 2007, Gypsy moth response to landscape structure differs from neutral model predictions-Implications for invasion monitoring: Biological Invasions, v. 9 , no. 5 , p. 585-595.

*Newman, D.J., Jr., Perault, D.R., and Shahady, T.D., 2006, Watershed development and sediment accumulation in a small urban lake: Lake and Reservoir Management, v. 22, no. 4, p. 303-307.

*Norris, J.R., Jackson, S.T., and Betancourt, J.L., 2006, Classification tree and minimum-volume ellipsoid analyses of the distribution of ponderosa pine in the Western USA: Journal of Biogeography, v. 33, p. 342-360.

*Noss, R.F.; Carroll, Carlos; Vance-Borland, Ken; and Wuerthner, George, 2002, A multicriteria assessment of the irreplaceability and vulnerability of sites in the Greater Yellowstone Ecosystem: Conservation Biology, v. 16, no. 4, p. 895-908.

*O'Brien, C.S., Ockenfels, R.A., Bristow, K.D., and Boe, S.R., 2006, Habitat models—Desert bighorn sheep in the Silver Bell Mountains revisited, in Cain, J.W. III, and Krausman, P.R., eds., Managing Wildlife in the Southwest-New Challenges for the $21^{\text {st }}$ Century, Proceedings of the Symposium, Alpine, Tex., August 9-11, 2005: Tuscon, Ariz., Southwest Section of the Wildlife Society, p 10-24, accessed March 8, 2011, at http://www.sulross.edu/brinrm/pubs/Southwest2006_sm.pdf\#page=19. *Office of Water Quality, 2006a, Total maximum daily load for Escherichia coli (E. coli) for the Lambs Creek watershed-Morgan County: Indianapolis, Indiana Department of Environmental Management, Office of Water Quality, unpublished manuscript, 30 p., accessed March 28, 2011, at http://www.epa.gov/waters/tmdldocs/Lambs\%20Creek\%20Watershed\%20TMDL\%20-\%20USEPA\% 20APPROVAL\%20(Version\%208).pdf.

*Office of Water Quality, 2006b, Total maximum daily load for Escherichia coli (E. coli) for the Plummer Creek watershed - Greene County: Indianapolis, Indiana Department of Environmental Management, Office of Water Quality, unpublished manuscript, 39 p., accessed March 29, 2011, at http://www.epa.gov/waters/tmaldocs/23109_plumer-crk-finaltmdl.pdf.

*Office of Water Quality, 2006c, Total maximum daily load for Escherichia coli (E. coli) for the Richland Creek watershed, Greene, Monroe, and Owen Counties: Indianapolis, Indiana Department of Environmental Management, Office of Water Quality, unpublished manuscript, 46 p., accessed March 29, 2011, at http://www.indiana.gov/idem/files/tmdl_richlandcrk_report.pdf.

*Office of Water Quality, 2007, Total maximum daily load for Escherichia coli (E. coli) for the Sugar Creek watershed-Hancock, Henry, Johnson, Madison, and Shelby Counties: Indianapolis, Indiana Department of Environmental Management, Office of Water Quality, unpublished manuscript, 47 p., 
accessed April 6, 2011, at http://www.epa.gov/waters/tmdldocs/Sugar\%20Creek\%20Watershed\% 20TMDL\%20USEPA\%20APPROVAL\%20Version\%209.pdf.

Okubo, Y., 1997, Bibliometric indicators and analysis of research systems-Methods and examples: Paris, France, Organisation for Economic Cooperation and Development STE Working Papers 1997/1, 70 p.

*Oldham, J.V., 2002, Estimating biogenic non-methane hydrocarbon emissions for the Wasatch Front through a high-resolution, gridded, biogenic volatile organic compound emissions inventory: Logan, Utah State University, Master's thesis, 119 p., accessed March 7, 2011, at http://www.dtic.mil/cgi-bin/ GetTRDoc? $A D=A D A 410695 \&$ Location $=U 2 \&$ doc $=$ GetTRDoc.pdf.

*Oleson, K.W., Driese, K.L., Maslanik, J.A., Emery, W.J., and Reiners, W.A., 1997, The sensitivity of a land surface parameterization scheme to the choice of remotely sensed land-cover datasets: Monthly Weather Review, v. 125, no. 7, p. 1537-1555.

*Orr, B.J., Casady, G.M., Tuttle, D.G., van Leeuwen, W.J.D., Baker, L.E., McDonald, C.I., and Marsh, S.E., 2005, Phenology and trend indicators derived from spatially dynamic bi-weekly satellite imagery to support ecosystem monitoring, in Gottfried, G.J., Gebow, B.S., Eskew, L.G., and Edminster, C.B., comps., Connecting mountain islands and desert seas-Biodiversity and management of the Madrean Archipelago II, Proceedings: Fort Collins, Colo., U.S. Department of Agriculture Forest Service, Rocky Mountain Research Station, RMRS-P-36, p. 206-211.

*Orr, B.J., Grunberg, Wolfgang, Cockerham, A. B., Thwaits, A.Y., Severson, H.S., Lerman, N.M.D., Miller, R.M., Haseltine, Michael, Morehouse, B.J., Overpeck, J.T., Yool, S.R., Swetnam, T.W., and Christopherson, G.L., 2005, An on-line interface for integrated modeling of wildlife, climate, and society for strategic planning for the Sky Islands, in Gottfried, G.J., Gebow, B.S., Eskew, L.G., and Edminster, C.B., comps., Connecting mountain islands and desert seas-Biodiversity and management of the Madrean Archipelago II, Proceedings: Fort Collins, Colo., U.S. Department of Agriculture Forest Service, Rocky Mountain Research Station, RMRS-P-36, p. 469-473.

*Oukrop, C.M., 2010, Assessing quaking aspen (Populus tremuloides) decline on Cedar Mountain in southern Utah using remote sensing and geographic information systems: Logan, Utah State University, Master's thesis, 129 p., accessed February 3, 2011, at http://digitalcommons.usu.edu/etd/582.

*Overton, C.T., Schmitz, R.A., and Casazza, M.L., 2005, Post-precipitation bias in band-tailed pigeon surveys conducted at mineral sites: Wildlife Society Bulletin, v. 33, no. 3, p. 1047-1054.

*Overton, C.T., Schmitz, R.A., and Casazza, M.L., 2006, Linking landscape characteristics to mineral site use by band-tailed pigeons in western Oregon - Coarse-filter conservation with fine-filter tuning: Natural Areas Journal, v. 26, no. 1, p. 38-46.

*Parajuli, P.B., Douglas-Mankin, K.R., Barnes, P.L., and Rossi, C.G., 2009, Fecal bacteria source characterization and sensitivity analysis of SWAT 2005: Transactions of the ASABE, v. 52, no. 6 , p. 1847-1858, accessed February 28, 2011, at http://hdl.handle.net/10113/38214.

*Parajuli, P.B., Mankin, K.R., and Barnes, P.L., 2008, Applicability of targeting vegetative filter strips to abate fecal bacteria and sediment yield using SWAT: Agricultural Water Management, v. 95, no. 10, p. 1189-1200.

*Parajuli, P.B., Mankin, K.R., and Barnes, P.L., 2009, Source specific fecal bacteria modeling using soil and water assessment tool model: Bioresource Technology, v. 100, no. 2, p. 953-963.

*Parés-Ramos, I.K., Gould, W.A., and Aide, T.M., 2008, Agricultural abandonment, suburban growth, and forest expansion in Puerto Rico between 1991 and 2000: Ecology and Society, v. 13, no. 2, paper 1, accessed February 28, 2011, at http://www.ecologyandsociety.org/vol13/iss2/art1/. 
*Park, Sunyurp, 2008, Harmonic analysis of long-term MODIS time-series data for vegetation dynamics in Hawaii, in ASPRS 2008 Annual Conference, Portland, Oreg., 2008, Proceedings: Bethesda, Md., American Society for Photogrammetry and Remote Sensing (ASPRS), 8 p., accessed March 30, 2011, at http://www.asprs.org/a/publications/proceedings/portland08/0060.pdf.

*Park, Sunyurp, and Egbert, S.L., 2008, Remote sensing-measured impacts of the Conservation Reserve Program (CRP) on landscape structure in southwestern Kansas: GIScience and Remote Sensing, v. 45 , no. 1, p. 83-108.

*Parmenter, A.W.; Hansen, Andrew; Kennedy, R.E.; Cohen, Warren; Langner, Ute; Lawrence, Rick; Maxwell, Bruce; Gallant, Alisa; and Aspinall, Richard, 2003, Land use and land cover change in the Greater Yellowstone Ecosystem-1975-1995: Ecological Applications, v. 13, no. 3, p. 687-703.

*Patraw, Kimberly; Van Neil, Tom; Long, Jim; Crane, John; and Falconer, Allan, 1996, Land condition and vegetation trend analysis using ArcView 2.1 and Avenue, in 1996 ESRI International Users Conference, Palm Springs, Calif., Proceedings: Washington, D.C., Environmental Systems Research Institute (ESRI), paper 184, accessed January 14, 2011, at http://proceedings.esri.com/library/userconf/proc96/TO200/PAP184/P184.HTM.

*Pau, Stephanie, Okin, G.S., and Gillespie, T.W., 2010, Asynchronous response of tropical forest leaf phenology to seasonal and El-Niño-driven drought: PLoS ONE, v. 5, no. 6, e11325, accessed March 29, 2011, at http://www.plosone.org/article/info\%3Adoi\%2F10.1371\%2Fjournal.pone.0011325.

*Pease, K.M.; Freedman, A.H.; Pollinger, J.P.; McCormack, J.E.; Buermann, Wolfgang; Rodzen, Jeff; Banks, Jim; Meredith, Erin; Bleich, V.C.; Schaefer, R.J.; Jones, Ken; and Wayne, R.K., 2009, Landscape genetics of California mule deer (Odocoileus hemionus) - the roles of ecological and historical factors in generating differentiation: Molecular Ecology, v. 18, no. 9, p. 1848-1862.

Pendlebury, D.A., 2009, The use and misuse of journal metrics and other citation indicators: Archivum Immunologiae et Therapiae Experimentalis, v. 57, no. 1, p. 1-11.

*Peterson, A.T., 2005, Kansas Gap Analysis-The importance of validating distributional models before using them: Southwestern Naturalist, v. 50, no. 2, p. 230-236.

*Peterson, A.T., and Kluza, D.A., 2003, New distributional modelling approaches for gap analysis: Animal Conservation, v. 6, no. 1, p. 47-54.

*Peterson, Dana, 2010, The Kansas next-generation land use/land cover mapping initiative, in MAGIC 2010 conference, Kansas City, Missouri, April 18-22, 2010: MidAmerica GIS Consortium, accessed March 29, 2011, at http://www.magicgis.org/magic/symposiums/2010/presentations/Peterson_MAG290.pdf.

*Peterson, Dana; Whistler, Jerry; Bishop, Chris; Egbert, Stephen; and Martinko, Ed, 2009, The Kansas next-generation land use/land cover mapping initiative, in ASPRS 2009 Annual Conference, Baltimore, Md., 2009, Proceedings: Baltimore, Md., American Society for Photogrammetry and Remote Sensing (ASPRS), 12 p., accessed March 30, 2011, at http://www.asprs.org/publications/proceedings/baltimore09/0074.pdf.

*Peterson, D.L., Egbert, S.L., Price, K.P., and Martinko, E.A., 2004, Identifying historical and recent land-cover changes in Kansas using postclassification change detection techniques: Transactions of the Kansas Academy of Science, v. 107, nos. 3-4, p. 105-118.

*Peterson, E.B., 2005, Estimating cover of an invasive grass (Bromus tectorum) using tobit regression and phenology derived from two dates of Landsat ETM+ data: International Journal of Remote Sensing, v. 26, no. 12, p. 2491-2507.

*Peterson, E.B., 2006, A map of invasive annual grasses in Nevada derived from multitemporal Landsat 5 TM imagery [Report for the U.S. Department of the Interior Bureau of Land Management, Nevada 
State Office]: Carson City, Nevada Natural Heritage Program, 15 p., accessed February 26, 2011, at http://heritage.nv.gov/reports/anngrass_text.pdf.

*Peterson, E.B., 2007, A map of annual grasses in the Owyhee Uplands, spring 2006, derived from multitemporal Landsat 5 TM imagery [Report for the U.S. Department of the Interior Bureau of Land Management, Nevada State Office]: Carson City, Nevada Natural Heritage Program, 32 p., accessed March 5, 2011, at http://heritage.nv.gov/reports/anngrowy_text.pdf.

*Peterson, E.B., 2008a, A synthesis of vegetation maps for Nevada - Initiating a "living" vegetation map: Carson City, Nevada Natural Heritage Program, 44 p., accessed March 7, 2011, at http://heritage.nv.gov/reports/synthmap.pdf.

*Peterson, E.B., 2008b, Invasion of the exotic grasses-Mapping their progression via satellite, in Shrublands under fire-Disturbance and recovery in a changing world, June 6-8, 2006, Cedar City, Utah: Fort Collins, Colo., U.S. Department of Agriculture Forest Service, Rocky Mountain Research Station, RMRS-P-52, p. 33-39.

*Pitman, J.C., Hagen, C.A., Robel, R.J., Loughin, T.M., and Applegate, R.D., 2005, Location and success of lesser prairie-chicken nests in relation to vegetation and human disturbance: Journal of Wildlife Management, v. 69, no. 3, p. 1259-1269.

*Pocewicz, Amy, Copeland, H.E., and Buchmann, Melissa, 2009, The state of habitat protection in Wyoming: The Nature Conservancy, 12 p., accessed January 22, 2011, at

http://www.nature.org/wherewework/northamerica/states/wyoming/files/wy_science_habitat_report_ layout_1.pdf.

*Polasky, Stephen; Camm, J.D.; Solow, A.R.; Csuti, Blair; White, Denis; and Ding, Rugang, 2000, Choosing reserve networks with incomplete species information: Biological Conservation, v. 94, p. $1-10$.

Porter, A.L., Newman, N.C., Myers, W.W., and Schoeneck, David, 2003, Projects and publicationsInteresting patterns in US Environmental Protection Agency research: Research Evaluation, v. 12, no. 3, p. 171-182.

Porter, A.L., Schoeneck, D.J., Roessner, David, and Garner, Jon, 2010, Practical research proposal and publication profiling: Research Evaluation, v. 19, no. 1, p. 29-44.

*Porter, Stacey; Mallory, Bonnie; and Hecht, Barry, 2002, Review of phase II instream "unimpaired" flows in the Klamath River: Berkeley, Calif., Balance Hydrologics, Inc., 33 p., accessed February 3, 2011, at http://www.balancehydro.com/pdf/202009klam.pdf.

*Potere, David; Woodcock, C.E.; Schneider, Annemarie; Ozdogan, Mutlu; and Baccini, Alessandro, 2007, Patterns in forest clearing along the Appalachian Trail corridor: Photogrammetric Engineering \& Remote Sensing, v. 73, no. 7, p. 783-791.

*Poti, Matthew, 2010, Identifying priority conservation areas in Georgetown County, South Carolina: Durham, N.C., Duke University, Master's thesis, 45 p., accessed March 3, 2011, at http://dukespace.lib.duke.edu:8080/dspace/bitstream/handle/10161/2233/Poti_MP_final.pdf? sequence $=1$.

*Potosnak, M.J., Guenther, A.B., and Papiez, M.R., 2006, Biogenic volatile organic compound emission inventory improvement project-Final report: Desert Research Institute, 42 p., accessed March 3, 2011, at http://www.clarkcountynv.gov/Depts/daqem/Documents/Planning/Studies/Emission InventoryResearch/Biogenic_VOC_Emission_Inventory_Improvement_Project_(2006).pdf.

*Pratt, P.D., Slone, D.H., and Ferriter, A.P., 2003, Quantifying the adventive geographic distribution and dispersal rate of Oxyops vitiosa, a biological control agent of the invasive tree Melaleuca quinquenervia: Gainsville, University of Florida, Institute of Food and Agricultural Sciences, 
unpublished manuscript, 18 p., accessed March 3, 2011, at

http://tame.ifas.ufl.edu/pdfs/research/Project\%205.pdf.

*Pratt, P.D., Slone, D.H., Rayamajhi, M.B., Van, T.K., and Center, T.D., 2003, Geographic distribution and dispersal rate of Oxyops vitiosa (Coleoptera: Curculionidae), a biological control agent of the invasive tree Melaleuca quinquenervia in south Florida: Environmental Entomology, v. 32, no. 2, p. 397-406.

*Pu, R., Gong, P., Li, Z., and Scarborough, J., 2004, A dynamic algorithm for wildfire mapping with NOAA/AVHRR data: International Journal of Wildland Fire, v. 13, p. 275-285.

*Purcell, K.L, and Stephens, S.L., 2006, Changing fire regimes and the avifauna of California oak woodlands: Studies in Avian Biology, v. 30, p. 33-45, accessed March 7, 2011, at http://www.fs.fed.us/psw/publications/purcell/psw_2006_purcell001.pdf.

*Pyke, C.R., 2005a, Assessing climate change impacts on vernal pool ecosystems and endemic branchiopods: Ecosystems, v. 8, no. 1, p. 95-105.

*Pyke, C.R., 2005b, Interactions between habitat loss and climate change-Implications for fairy shrimp in the central valley ecoregion of California, USA: Climatic Change, v. 68, nos. 1-2, p. $199-218$.

*Rabe, Andrea, and Calonje, Christopher, 2009, Terrestrial vegetation, chap. 6 of Rabe, Andrea, and Calonje, Christopher, Lower Sprague-Lower Williamson Watershed Assessment: Klamath Falls, Oreg., Klamath Watershed Partnership, 36 p., accessed March 8, 2011, at http://www.klamathpartnership.org/pdf/lslw_watershed_assessment/lslwwa_chapter_6_Terrestrial_ Vegetation.pdf.

*Rabe, M.J., Rosenstock, S.S., and Nielsen, D.I., 2005, Feral africanized honey bees (Apis mellifere) in Sonoran Desert habitats of southwestern Arizona: Southwestern Naturalist, v. 50, no. 3, p. 307-311.

*Rachlow, J.L., and Svancara, L.K., 2006, Prioritizing habitat for surveys of an uncommon mammalA modeling approach applied to pygmy rabbits: Journal of Mammalogy, v. 87, no. 5, p. 827-833.

*Rack, Jim; Albers, Mike; and Albers, Jana, 2006, Two-lined chestnut borer risk assessment in north central Minnesota in 2006 FHM Poster Presentations: Arlington, Va., U.S. Department of Agriculture Forest Service, National Forest Health Monitoring Program, 1 pl., accessed March 14, 2011, at http://www.fhm.fs.fed.us/posters/posters06/tl_chestnut_borer.pdf.

*Radwell, Andrea, 2000, Ecological integrity assessment of Ozark rivers to determine suitability for protective status: Fayetteville, University of Arkansas, Master's thesis, $107 \mathrm{p}$.

*Ramsey, Elijah, III; Rangoonwala, Amina; Middleton, Beth; and Lu, Zhong, 2009, Satellite optical and radar data used to track wetland forest impact and short-term recovery from Hurricane Katrina: Wetlands, v. 29, no. 1, p. 66-79.

*Ramsey, R.D.; Patrow, Kimberly; Biggs, Brian; Falconer, Allan; Van Neil, Tom; Halisky, Merland; and Spencer, Richard, 1995, GIS for Environmental Management-A hierarchical database structure, in 1995 ESRI International User Conference, Palm Springs, Calif., Proceedings: Redlands, Calif., Environmental Systems Research Institute (ESRI), paper 111, accessed January 14, 2011, at http://proceedings.esri.com/library/userconf/proc95/to150/p111.html.

*Randhir, Timothy, and Ekness, Paul, 2009, Urbanization effects on watershed habitat potential-A multivariate assessment of thresholds and interactions: Ecohydrology, v. 2, no. 1, p. 88-101.

*Rao, Mahesh; Fan, Guoliang; Thomas, Johnson; Cherian, Ginto; Chudiwale, Varun; and Awawdeh, Muheeb, 2007, A web-based GIS Decision Support System for managing and planning USDA's Conservation Reserve Program (CRP): Environmental Modelling \& Software, v. 22, p. 1270-1280.

*Rasmussen, Craig, 2006, Distribution of soil organic and inorganic carbon pools by biome and soil taxa in Arizona: Soil Science Society of America Journal, v. 70, no. 1, p. 256-265. 
*Ready, Richard, and Guignet, Dennis, n.d., Methodology for projecting land cover change in the CARA Region: University Park, Pennsylvania State University, unpublished manuscript, accessed March 20, 2011, at http://www.cara.psu.edu:8001/about/LndUse_Methodology.pdf.

*Redman, J.M., Calkins, M.T., Andersen, M.C., and Boykin, K.G., 2009, Development of future habitat suitability models for the swift fox (Vulpes velox) and palmer's chipmunk (Tamias palmeri) ) [abs.], in 94th ESA annual meeting, Albuquerque, N. Mex., August 2-7, 2009: Washington, D.C., Ecological Society of America, accessed March 28, 2011, at http://esameetings.allenpress.com/2009/Paper18063.html.

*Reed, L.A., Pennington, P.L., and Wirth, Edward, 2010, A survey of trace element distribution in tissues of stone crabs (Menippe mercenaria) from South Carolina Coastal Waters: Marine Pollution Bulletin, v. 60, no. 12, p. 2297-2302.

*Regmi, Binaya, 2002, Web-enabled spatial decision support system for interdisciplinary watershed management: Blacksburg, Virginia Polytechnic Institute and State University, Master's thesis, $111 \mathrm{p}$.

*Restani, Marco, Kimmel, R.O., Fieberg, J.R., and Goetz, S.L., 2009, Effects of supplemental food and experience on winter survival of transplanted wild turkeys: Wilson Journal of Ornithology, v. 121, no. 2, p. 366-377.

Retzer, Vroni, and Jurasinski, Gerald, 2009, Towards objectivity in research evaluation using bibliometric indicators - A protocol for incorporating complexity: Basic and Applied Ecology, v. 10, no. 5, p. 393-400.

Rey-Rocha, Jesús, Martín-Sempere, M.J., Martínez-Frías, J., and López-Vera, F., 2001, Some misuses of journal impact factor in research evaluation: Cortex Forum, v. 37, no. 4, p. 595-597.

*Rice, M.B., Ballard, W.B., Fish, E.B., McIntyre, N.E., and Holdermann, D., 2008, The importance of accurate landuse/landcover maps for assessing habitat suitability for black bear (Ursus americanus) in the Trans-Pecos region of Texas: Wildlife Biology in Practice, v. 4, no. 2, p. 48-56.

*Riemann, Rachel; Lister, Andrew; Hoppus, Michael; and Lister, Tonya, 2003, Fragmentation statistics for FIA - Designing an approach, in McRoberts, R.E., Reams, G.A., Van Deusen, P.C., Moser, J.W., eds., Third Annual Forest Inventory and Analysis Symposium, Traverse City, Mich., October 17-19, 2001, Proceedings: St. Paul, Minn., U.S. Department of Agriculture Forest Service, North Central Research Station, General Technical Report NC-230, p. 146-155.

*Riitters, K.H., Coulston, J.W., and Wickham, J.D., 2003, Localizing national fragmentation statistics with forest type maps: Journal of Forestry, v. 101, no. 4, p. 18-22.

*Rimmer, C.C., McFarland, K.P., Lambert, J.D., and Renfrew, R.B., 2004, Evaluating the use of Vermont ski areas by Bicknell's Thrush-Applications for Whiteface Mountain, New York: Woodstock, Vermont Institute of Natural Science, 46 p., accessed March 5, 2011, at http://www.vtecostudies.org/PDF/BITHORDA2004.pdf.

*Rink, G.R., and Cully, A.C., 2007, A checklist of the vascular flora of Yucca House National Monument and surrounding lands, Montezuma County, Colorado: Journal of the Torrey Botanical Society, v. 134, no. 2, p. 289-300.

*Robbie, W.A., 2004, Grassland assessment categories and extent, chap. 2 of Finch, D.M., ed., Assessment of grassland ecosystem conditions in the Southwestern United States: Fort Collins, Colo., U.S. Department of Agriculture Forest Service, Rocky Mountain Research Station, General Technical Report RMRS-GTR-135, v. 1, p. 11-17.

*Roberson, J.L., 2008, Bird species prediction modeling-A comparison of multiple modeling techniques at Francis Marion National Forest in South Carolina: Columbia, University of South Carolina, Master's thesis, $122 \mathrm{p}$. 
*Roberson, J.L., and Kupfer, J.A., 2009, Bird species prediction modeling-A comparison of multiple modeling techniques at Francis Marion National Forest in South Carolina., in Papers from the Annual Meeting of the Association of American Geographers, Las Vegas, Nev., March 22-27, 2009:

Association of American Geographers, accessed February 3, 2011 at http://meridian.aag.org/callforpapers/program/AbstractDetail.cfm? AbstractID $=23541$.

*Robison, Ramona, and DiTomaso, J.M., 2010, Distribution and community associations of Cape ivy (Delairea odorata) in California: Madroño, v. 57, no. 2, p. 85-94.

*Rodman, L.C., and Meentemeyer, R.K., 2006, A geographic analysis of wind turbine placement in northern California: Energy Policy, v. 34, p. 2137-2149.

Roessner, J.D., 2002, Outcome measurement in the USA-State of the art: Research Evaluation, v. 11, no. 2, p. 85-93.

*Rogers, P.C., Leffler, A.J., and Ryel, R.J., 2010, Landscape assessment of a stable aspen community in southern Utah, USA: Forest Ecology and Management, v. 259, p. 487-495.

*Roldan, M.K., 2001, Utilizing GIS for mapping reforestation of an agricultural landscape, 1939-1993, in Coon Creek Watershed, Wisconsin: Winona, Saint Mary's University of Minnesota, Department of Resource Analysis, 15 p., accessed January 11, 2011, at http://www2.smumn.edu/deptpages/ ra/gis/GradProjects/RoldanM.pdf.

*Root, K.V., Akçakaya, H.R., and Ginzburg, Lev, 2003, A multispecies approach to ecological valuation and conservation: Conservation Biology, v. 17, no. 1, p. 196-206.

Rossi, P.H., Lipsey, M.W., and Freeman, H.E., 2004, Evaluation-A systematic approach (7th ed.): Thousand Oaks, Calif., Sage Publications.

*Roth, J.E., Kelly, J.P., Sydeman, W.J., and Colwell, M.A., 2004, Sex differences in space use of breeding common ravens in western Marin County, California: Condor, v. 106, no. 3, p. 529-539.

*Roth, T.C., II, Vetter, W.E., and Lima, S.L., 2008, Spatial ecology of winting accipiter hawks-Home range, habitat use, and the influence of bird feeders: Condor, v. 110, no. 2, p. 260-268.

*Rubbo, M.J., and Kiesecker, J.M., 2005, Amphibian breeding distribution in an urbanized landscape: Conservation Biology, v. 19, no. 2, p. 504-511.

*Rumsey, David, and Williams, Meredith, 2002, Historical maps in GIS, chap. 1 of Knowles, A.K., ed., Past time, past place_-GIS for history: Redlands, Calif., Environmental Systems Research Institute (ESRI) Press, p. 1-18.

*Rustigan, H.L., and Krohn, W.B., 2002, GIS-based evaluation of waterfowl and wading bird habitats in Maine: Orono, University of Maine, 65 p., accessed February 3, 2011, at http://www.fws.gov/r5gomp/me/mdifw/inland-wwh.pdf.

*Ryman, G.L., 2010, More than bucks and acres-Assessing the value of conserved lands: Durham, N.C., Duke University, Master's thesis, 59 p., accessed March 4, 2011, at http://dukespace.lib.duke.edu:8080/dspace/bitstream/handle/10161/2176/MP_FINAL2.pdf? sequence $=1$.

*Sacks, B.N., Chomel, B.B., and Kasten, R.W., 2004, Modeling the distribution and abundance of the non-native parasite, canine heartworm, in California coyotes: Oikos, v. 105, no. 2, p. 415-425.

*Sader, S.A., Jin, Suming, Metzler, J.W., and Hoppus, Michael, 2006, Exploratory analysis of forest harvest and regeneration pattern among multiple landowners: Forestry Chronicle, v. 82, no. 2, p. 203-210.

*Sader, S.A., and Legaard, K.R., 2008, Inclusion of forest harvest legacies, forest type, and regeneration spatial patterns in updated forest maps-A comparison of mapping results: Forest Ecology and Management, v. 255, p. 3846-3856. 
*Salmon, Olivia; Brunson, Mark; and Kuhns, Michael, 2006, Benefit-based audience segmentation-A tool for identifying nonindustrial private forest owner education needs: Journal of Forestry, v. 104, no. 8, p. 419-425.

*Sarkar, Sahotra, and Garson, Justin, 2004, Multiple criterion synchronisation for conservation area network design-The use of non-dominated alternative sets: Conservation and Society, v. 2, no. 2, p. 433-448.

*Scarborough, James; Clinton, Nicolas; Pu, Ruilang; and Gong, Peng, 2001, Creating a statewide spatially and temporally allocated wildfire and prescribed burn emission inventory using consistent emission factors: Berkeley, University of California, unpublished manuscript, 55 p., accessed March 7, 2011, at http://o3.arb.ca.gov/research/apr/past/98-726.pdf.

*Schaaf, C.B.; Lucht, Wolfgang; Strahler, A.H.; Hodges, J.C.F.; d'Entremont, R.P., 1998, Relationship between land surface properties and BRDF/albedo parameters using satellite data, in IEEE International Geoscience and Remote Sensing Symposium (IGARSS), Boston, Mass., July 6-10, 1998, Proceedings: Institute of Electrical Engineers (IEEE), v. 3, p. 1277-1279.

*Schaefer, S.M., 2002, An assessment of methods for testing the reliability of wildlife occurrence models used in gap analysis: Orono, University of Maine, Master's thesis, $155 \mathrm{p}$.

*Schoenberg, Kerri, and Randhir, T.O., 2010, Prioritization of watershed habitat for neotropical migratory birds: International Journal of Biodiversity and Conservation, v. 2., no. 9, p. 250-262. Schubert, A., Glaenzel, W., and Braun, T., 1988, Against absolute methods, chap. 5 of Van Raan, A.F.J., ed., Handbook of quantitative studies of science and technology: Amsterdam, Elsevier Science Publishers, p. 137-176.

*Schultz, R.J., Jr.; Edwards, T.C., Jr.; Moisen, G.G.; and Frescino, T.S., 2002, Development and validation of spatially explicit habitat models for cavity-nesting birds in Fishlake National Forest, Utah: Logan, Utah State University, unpublished manuscript, accessed March 7, 2011, at http://digitalcommons.usu.edu/cgi/viewcontent.cgi? article $=1157 \&$ context $=$ govdocs.

*Schumacher, J.V., Redmond, R.L., Hart, M.M., and Jensen, M.E., 2000, Mapping patterns of human use and potential resource conflicts on public lands: Environmental Monitoring and Assessment, v. 64 , p. $127-137$.

*Schwilk, D.W., and Keeley, J.E., 2006, The role of fire refugia in the distribution of Pinus sabiniana (pinaceae) in the southern Sierra Nevada: Madroño, v. 53, no. 4, p. 364-372.

*Scott, J.M., Davis, F.W., McGhie, G., Wright, R.G., Groves, C., and Estes, J., 2001, Nature reservesDo they capture the full range of America's biological diversity?: Ecological Applications, v. 11, no. 4, p. 999-1007.

*Scott, Klaus, n.d., Overview of biogenic VOC emissions using the BEIGIS model: Sacramento, California Environmental Protection Agency, Air Resources Board, accessed March 14, 2011, at http://eos.arb.ca.gov/eos/scos97/BiogenicsMethodology.pdf.

*Scott, K.I., 2000, Development of a biogenic hydrocarbon emission inventory for the central California ozone study domain: Sacramento, California Environmental Protection Agency, Air Resources Board, Appendix B, 24 p., accessed March 8, 2011, at http://eos.arb.ca.gov/eos/PROJECTS/sip/ccos/ JulyAug2000\%20SIP\%20Modeling\%20Doc\%20(App\%20B)\%2011-26-03.pdf.

*Scott, K.I., and Benjamin, M.T., 2003, Development of a biogenic volatile organic compounds emission inventory for the SCOS97-NARSTO domain: Atmospheric Environment, v. 37, suppl. 2, p. 39-49.

*Scott, Thad; Hauck, Larry; and Jones, Tim, 2003, Final report-Technical use attainability analysis Clear Fork Trinity River (sStream segments 0831 and 0833): Stephenville, Texas, Tarleton State University, Texas Institute for Applied Environmental Research, 45 p., accessed March 4, 2011, at 
http://www.tceq.com/assets/public/implementation/water/tmdl/28clearforktrin/

28-clearforkfinalreport.pdf.

*Secchi, Silvia., 2007, Watching corn grow-A hedonic study of the Iowa landscape: Ames, Iowa State University Center for Agricultural and Rural Development, Working Paper 07-WP 445, accessed March 29, 2011, at http://www.card.iastate.edu/publications/DBS/PDFFiles/07wp445.pdf.

*Secchi, Silvia; Tyndall, John; Schulte, L.A.; and Asbjornsen, Heidi, 2008, High crop prices and conservation: Journal of Soil and Water Conservation, v. 63, no. 3, p. 68A-73A.

Seglen, P.O., 1997, Citations and journal impact factors-Questionable indicators of research quality: Allergy, v. 52, no. 11, p. 1050-1056.

*Shaffer, Jonathan, 2009, Prioritization of old-growth forest conservation on the Pisgah National Forest: Durham, N.C., Duke University, Master's thesis, 35 p. accessed March 4, 2011, at http://dukespace.lib.duke.edu:8080/dspace/bitstream/handle/10161/1373/MP_Shaffer.pdf? sequence $=1$.

Shapira, Philip; Youtie, Jan; and Mohaptra, Sushanta, 2003, Linking research production and development outcomes at the regional level: Research Evaluation, v. 12, no. 2, p. 105-116.

*Sherrouse, B.C., Clement, J.M., and Semmens, D.J., 2011, A GIS application for assessing, mapping, and quantifying the social values of ecosystem services: Applied Geography, v. 31, no. 2, p. 748-760.

*Shilling, Fraser, and Girvetz, Evan, 2003. Bear River watershed—Disturbance inventory and spatial data encyclopedia: University of California, Davis, Department of Environmental Science and Policy, 50 p., accessed March 7, 2011, at http://www.foothillswaternetwork.org/watersheds/ interactive-journey/data/BearDistInvFin803.pdf.

*Shilling, Fraser; Girvetz, Evan; Erichsen, Chris; Johnson, Brenda; and Nichols, Pete; 2002, A guide to wildlands conservation in the Greater Sierra Nevada bioregion: University of California, Davis, Institute of Transportation Studies, 187 p., accessed March 7, 2011, at http://escholarship.org/uc/item/9978b2rq;jsessionid=BBCFB5327C0A36B8DF396DEFB103FBF9.

*Shinneman, D.J., Watson, John, and Martin, W.W., 2000, The state of the southern Rockies ecoregion-A look at species imperilment, ecosystem protection, and a conservation opportunity: Endangered Species Update, v. 17, no. 1, p. 2-9.

*Shirgaokar, Manish, and Deakin, Elizabeth, 2001, California housing trends-Implications for transportation planning: Berkeley, University of California Transportation Center, unpublished manuscript, 30 p., accessed March 5, 2011, at http://www.uctc.net/research/papers/532.pdf.

*Shirk, A.J., Wallin, D.O., Cushman, S.A., Rice, C.G., and Warheit, K.I., 2010, Inferring landscape effects on gene flow-A new model selection framework: Molecular Ecology, v. 19, no. 17, p. 3603-3619.

*Shriner, S.A., Wilson, K.R., and Flather, C.H., 2006, Reserve networks based on richness hotspots and representation vary with scale: Ecological Applications, v. 16, no. 5, p. 1660-1673.

*Shriver, D.M., and Randhir, T.O., 2006, Integrating stakeholder values with multiple attributes to quantify watershed performance: Water Resources Research, v. 42, 15 p.

*Singleton, P.H., Gaines, W.L., and Lehmkuhl, J.F., 2004, Landscape permeability for grizzly bear movements in Washington and southwestern British Columbia: Ursus, v. 15, no. 1, p. 90-103.

*Sloat, M.R., Shepard, B.B., White, R.G., and Carson, Steve, 2005, Influence of stream temperature on the spatial distribution of westslope cutthroat trout growth potential within the Madison River basin, Montana: North American Journal of Fisheries Management, v. 25, no. 1, p. 225-237.

*Smart, Lindsey, 2009, Characterizing spatial pattern and heterogeneity of pine forests in North Carolina's coastal plain using LiDAR: Durham, N.C., Duke University, Master's thesis, 73 p., accessed March 8, 2011, at http://dukespace.lib.duke.edu:8080/dspace/handle/10161/1027. 
*Snyder, S.A., Whitmore, J.H., Schneider, I.E., and Becker, D.R., 2008, Ecological criteria, participant preferences and location models - A GIS approach toward ATV trail planning: Applied Geography, v. 28, p. 248-258.

*Sork, V.L.; Davis F.W.; Westfall, Robert; Flint, Alan; Ikegami, Makihiko; Wang, Hongfang; and Grivet, Delphine, 2010, Gene movement and genetic association with regional climate gradients in California valley oak (Quercus lobata Née) in the face of climate change: Molecular Ecology, v. 19, no. 17, p. 3806-3823.

*Sowa, S.P., Annis, Gust, Morey, M.E., and Diamond, D.D., 2007, A gap analysis and comprehensive conservation strategy for riverine ecosystems of Missouri: Ecological Monographs, v. 77, no. 3, p. 301-334.

*Sponseller, R.A., and Benfield, E.F., 2001, Influences of land use on leaf breakdown in southern Appalachian headwater streams - A multiple-scale analysis: Journal of the North American Benthological Society, v. 20, no. 1, p. 44-59.

*Sridhar, Venkataramana, 2007, Evapotranspiration estimation and scaling effects over the Nebraska Sandhills: Great Plains Research, v. 17, p. 35-45.

*Staus, N.L., Strittholt, J.R., DellaSala, D.A., and Robinson, Rob, 2002, Rate and pattern of forest disturbance in the Klamath-Siskiyou ecoregion, USA, between 1972 and 1992: Landscape Ecology, v. 17 , no. 5 , p. $455-470$.

*Stein, B.A.; Scott, Cameron; and Benton, Nancy, 2008, Federal lands and endangered species-The role of military and other federal lands in sustaining biodiversity: BioScience, v. 58, no. 4, p. 339-347.

*Steinitz, Carl; Anderson, Robert; Arias, Hector; Bassett, Scott; Flaxman, Michael; Goode, Tomas; Maddock, Thomas, III; Mouat, David; Peiser, Richard; Shearer, Allan, 2005, Alternative futures for landscapes in the Upper San Pedro River Basin of Arizona and Sonora, in Ralph, C.J., and Rich, T.D., eds., Bird conservation implementation and integration in the Americas, Third International Partners in Flight Conference, Asilomar, Calif., March 20-24, 2002, Proceedings, v. 1: Albany, Calif., U.S. Department of Agriculture Forest Service, Pacific Southwest Research Station, General Technical Report PSW-GTR-191, p. 93-100.

*Stephenson, J.R., Volgarino, D.A., Nichols, G.A., and White, T.C., 1997, Developing a conservation strategy for southern California forests and woodlands in Pillsbury, N.H.; Verner, Jared; Tietje, W.D., tech. cords., Symposium on oak woodlands-Ecology, management, and urban interface issues, March 19-22, 1996 San Luis Obispo, Calif., Proceedings: Albany, Calif., U.S. Department of Agriculture Forest Service, Pacific Southwest Research Station, General Technical Report PSWGTR-160, p. 401-410.

*Stetson, Denise; Hubert, Jay; and Feldhamer, George, 2009, Population assessment of golden mice in Illinois - Relative abundance and sympatric white-footed mice: Peromyscus Newsletter, no. 44, p. 23-26, accessed March 16, 2011, at http://stkctr.biol.sc.edu/newsletters/pdfs/PN44.pdf\#page=23.

*Stevenson, M.R., 1998, Protecting biodiversity-Applying gap analysis in Spokane County, Washington: Seattle, University of Washington, Master's thesis, 127 p.

*St-Louis, Véronique, Pidgeon, A.M., Clayton, M.K., Locke, B.A., Bash, Dallas, and Radeloff, V.C., 2009, Satellite image texture and a vegetation index predict avian biodiversity in the Chihuahuan Desert of New Mexico: Ecography, v. 32, no. 3, p. 468-480.

*St-Louis, Véronique, Pidgeon, A.M., Clayton, M.K., Locke, B.A., Bash, Dallas, and Radeloff, V.C., 2010, Habitat variables explain Loggerhead Shrike occurrence in the northern Chihuahuan Desert, but are poor correlates of fitness measures: Landscape Ecology, v. 25, no. 4, p. 643-654. 
*Stoms, D.M., 1994, Scale dependence of species richness maps: Professional Geographer, v. 46, no. 3, p. 346-358.

*Stoms, D.M., 2000, GAP management status and regional indicators of threats to biodiversity: Landscape Ecology, v. 15, p. 21-33.

*Stoms, D.M., Bueno, M.J., Davis, F.W., Cassidy, K.M., Driese, K.L., and Kagan, J.S., 1998, Mapguided classification of regional land cover with multi-temporal AVHRR data: Photogrammetric Engineering and Remote Sensing, v. 64, p. 831-838.

*Stoms, D.M., Davis, F.W., Driese, K.L., Cassidy, K.M., and Murray, M.P., 1998, Gap analysis of the vegetation of the intermountain semi-desert ecoregion: Great Basin Naturalist, v. 58, no. 3, p. 199-216.

*Stoms, D.M., and Hargrove, W.W., 2000, Potential NDVI as a baseline for monitoring ecosystem functioning: International Journal of Remote Sensing, v. 21, no. 2., p. 401-407.

*Stonecipher, Clint, 2005, Classification of vegetation communities on the Cedar Mountain research site: Logan, Utah State University, unpublished paper, 12 p., accessed March 3, 2011, at http://www.gis.usu.edu/ doug/RS5750/PastProj/FA2005/ClintStonecipher_FinalProject.pdf.

*Stoner, D.C., Rieth, W.R., Wolfe, M.L., Mecham, M.B., and Neville, Ann, 2008, Long-distance dispersal of a female cougar in a basin and range landscape: Journal of Wildlife Management, v. 72, no. 4, p. 933-939.

*Storm, D.E., White, Michael, Smolen, M.D., and Zhang, Hailin, 2001, Modeling phosphorous loading for the Lake Eucha Basin-Final report: Stillwater, Oklahoma State University, unpublished manuscript, 81 p., accessed March 8, 2011, at http://storm.okstate.edu/eucha/modeling/OSU_EuchaReport_110101.pdf.

*Stralberg, Diana; Jongsomjit, Dennis; Howell, C.A.; Snyder, M.A.; Alexander, J.D.; Wiens, J.A.; and Root, T.L., 2009, Re-shuffling of species with climate disruption-A no-analog future for California birds?: PloS ONE, v. 4, no. 9, e6825, doi:10.1371/journal.pone.0006825, accessed February 21, 2011, at $h t t p: / / w w w . p r b o . o r g / r e f s / f i l e s / 12000 \_S t r a l b e r g . p d f$.

*Strauss, Amanda; Hurlbutt, Bryan; and O'Brady, Caitlin, 2006, Preserving biodiversity-Mapping habitat threat in the Rockies, in Hecox, W.E., Hurlbutt, B., and O'Brady, C., eds., The 2006 Colorado College state of the Rockies report card: Colorado Springs, Colorado College State of the Rockies Project, p. 61-74.

*Strickland, B.K., and Demarais, Stephen, 2008, Influence of landscape composition and structure on antler size of white-tailed deer: Journal of Wildlife Management, v. 72, no. 5, p. 1101-1108.

*Sullivan, T.J., Fernandez, I.J., Herlihy, A.T., Driscoll, C.T., McDonnell, T.C., Nowicki, N.A., Snyder, K.U., and Sutherland, J.W., 2006, Acid-base characteristics of soils in the Adirondack Mountains, New York: Soil Science Society of America Journal, v. 70, p. 141-152.

*Suter, J.F.; Conrad, Jon; Gomes, C.P.; van Hoeve, W.J.; and Sabharwal, Ashish, 2008, Optimal corridor design for grizzly bear in the U.S. Northern Rockies in American Agricultural Economics Association Annual Meeting, Orlando, Fla., July 27-29, 2008: St. Paul, University of Minnesota, 39 p., accessed March 7, 2011, at http://ageconsearch.umn.edu/bitstream/6207/2/469024.pdf.

*Svancara, L.K., Servheen, G., Melquist, W., Davis, D., and Scott, J.M., 2004, Habitat restoration across large areas-Assessing wildlife responses in the Clearwater Basin, Idaho: Western Journal of Applied Forestry, v. 19, no. 2, p. 123-132.

*Swantek, P.J., Halvorson, W.H., and Schwalbe, C.R., 1997, The use of GIS and the Internet for analyzing fire history of the Sonoran Desert-A regional approach in Arizona, in 1997 ESRI International User Conference, San Diego, Calif., Proceedings: Redlands, Calif., Environmental 
Systems Research Institute (ESRI), paper 196, accessed March 12, 2011, at

http://proceedings.esri.com/library/userconf/proc97/proc97/to200/pap196/p196.htm.

*Swier, V.J., 2006, Recent distribution and life history information for bats of eastern South Dakota:

Museum of Texas Tech University Occasional Papers, no. 264, 21 p., accessed March 7, 2011, at http://www.nsrl.ttu.edu/publications/opapers/ops/op264.pdf.

*Taft, O.W, Haig, S.M., and Kiilsgaard, Chris, 2004, Use of radar remote sensing (RADARSAT) to map winter wetland habitat for shorebirds in an agricultural landscape: Environmental Management, v. 33, no. 5, p. 750-763.

*Taylor, K.J., 2003, Bayesian belief networks-A conceptual approach to assessing risk to habitat: Logan, Utah State University, Master's thesis, 126 p., accessed March 8, 2011, at http://www.gis.usu.edu/ doug/Grads/KelliTaylor/Thesis.pdf.

*Teels, B.M., Rewa, C.A., and Myers, John, 2006, Aquatic condition response to riparian buffer establishment: Wildlife Society Bulletin, v. 34, no. 4, p. 927-935.

*Telesco, R.L., Van Manen, F.T., Clark, J.D., and Cartwright, M.E., 2007, Identifying sites for elk restoration in Arkansas: Journal of Wildlife Management, v. 71, no. 5, p. 1393-1403.

*Tetra Tech, Inc., n.d., TMDLs for total dissolved solids in the Duchesne River watershed: Fairfax, Va., Tetra Tech, Inc., 156 p., accessed March 8, 2011, at http://www.waterquality.utah.gov/TMDL/Duchesne_TMDLs.pdf.

*Tetra Tech, Inc., 2006, Total maximum daily loads for selected streams in the Coal River Watershed, West Virginia: Charleston, W. Va., Tetra Tech, Inc., 81 p., accessed March 7, 2011, at http://www.dep.wv.gov/WWE/watershed/TMDL/grpb/Documents/Coal\%202008/Final_Coal_TMDL_ Report_1_15_07.pdf.

*Tetra Tech, Inc., 2008, Total maximum daily loads for selected streams in the James River Watershed, West Virginia: Charleston, W. Va., Tetra Tech, Inc.,, accessed March 4, 2011, at http://www.monroecountywv.net/Forms/County_Plan/Appendices/App_F1.pdf

*Tetra Tech, Inc., 2010, Appendix F. Whooping crane likelihood of occurrence report in Ashley Wind Project, McIntosh County, North Dakota: Tennessee Valley Authority, 19 p., accessed January 10, 2011, at http://www.tva.gov/environment/reports/ashley/appendix_f.pdf.

*Thatcher, C.A., Van Manen, F.T., and Clark, J.D., 2009, A habitat assessment for Florida panther population expansion into central Florida: Journal of Mammalogy, v. 90, no. 4, p. 918-925.

Thelwall, Mike, 2004, Weak benchmarking indicators for formative and semi-evaluative assessment of research: Research Evaluation, v. 13, no. 1, p. 63-68.

*Theobald, D.M., 2001, Land-use dynamics beyond the American urban fringe: The Geographical Review, v. 91, no. 3, p. 544-564.

*Theobald, D.M., 2003, Targeting conservation action through assessment of protection and exurban threats: Conservation Biology, v. 17, no. 6, p. 1-13.

*Theobald, D.M., and Hobbs, N.T., 1999, Calculating landscape fragmentation using a gradient-based approach, in 1999 ESRI International User Conference, San Diego, Calif., Proceedings: Redlands, Calif., Environmental Systems Research Institute (ESRI), paper 141, accessed February 28, 2011, at http://proceedings.esri.com/library/userconf/proc99/proceed/papers/pap141/p141.htm.

*Theobald, D.M., Norman, J.B., and Sherburne, M.R., 2006, FunConn v1 user's manual—ArcGIS tools for functional connectivity modeling: Fort Collins, Colorado State University, Natural Resource Ecology Laboratory, 51 p., accessed January 19, 2011, at http://www.stat.colostate.edu/ nsu/ starmap/learningmaterials/technicalreports/FunConn.Users. Guide.pdf.

*Theobald, D.M., Peterson, Nathan, and Romme, W.H., 2004, The Colorado vegetation model-Using national land cover data and ancillary spatial data to produce a high resolution, fine-classification map 
of Colorado: Fort Collins, Colorado State University, 32 p., accessed January 15, 2011, at http://warnercnr.colostate.edu/ davet/cvm files/cvm report v8.pdf.

*Thogmartin, W.E., 1999, Landscape attributes and nest-site selection in wild turkeys: Auk, v. 116, no. 4, p. 912-923.

*Thogmartin, W.E., and Schaeffer, B.A., 2000, Landscape attributes associated with mortality events of wild turkeys in Arkansas: Wildlife Society Bulletin, v. 28, no. 4, p. 865-874.

*Thomas-Van Gundy, M.A., Nowacki, G.J., and Schuler, T.M., 2007, Rule-based mapping of fireadapted vegetation and fire regimes for the Monongahela National Forest: Newtown Square, Pa., U.S. Department of Agriculture Forest Service, Northern Research Station, General Technical Report NRS-12, 24 p., accessed March 7, 2011, at http://nrs.fs.fed.us/pubs/gtr/gtr_nrs 12.pdf.

**Thompson, B.C., Crist, P.J., Prior-Magee, J.S., Deitner, R.A., Garber, D.L., and Hughes, M.A., 1996, Gap analysis of biological diversity conservation in New Mexico using geographic information systems: Las Cruces, New Mexico State University, New Mexico Cooperative Fish and Wildlife Research Unit, Research Completion Report, Research Work Order No. 13.

*Thompson, B.C., Hughes, M.A., and Anderson, M.C., 2001, Effects of including non-breeding bird species on predicted bird distributions for conservation planning in New Mexico: Biological Conservation, v. 100, p. 229-242.

*Thorne, J.H., Cameron, Dick, and Quinn, J.F., 2006, A conservation design for the central coast of California and the evaluation of mountain lion as an umbrella species: Natural Areas Journal, v. 26, no. 2, p. 137-148.

*Thorne, J.H.; Kennedy, J.A.; Quinn, J.F.; McCoy, Michael; Keeler-Wolf, Todd; and Menke, John, 2004, A vegetation map of Napa County using the Manual of California Vegetation Classification and its comparison to other digital vegetation maps: Madroño, v. 51, no. 4, p. 343-363.

*Thorne, J.H., Morgan, B.J., and Kennedy, J.A., 2008, Vegetation change over sixty years in the central Sierra Nevada, California, USA: Madroño, v. 55, no. 3, p. 223-237.

*Thorne, Jim; Cameron, Dick; and Jigour, Verna, 2002, A guide to wildlands conservation in the central coast region of California: Oakland, Calif., California Wilderness Coalition, unpublished manuscript, 144 p., accessed March 8, 2011, at http://cain.ice.ucdavis.edu/repository/CC.pdf.

*Toney, Chris; Rollins, Matthew; Short, Karen; Frescino, Tracey; Tymcio, Ronald; and Peterson, Birgit, 2005, Use of FIA plot data in the LANDFIRE project, in McRoberts, R.E., Reams, G.A., Van Deusen, P.C., and McWilliams, W.H., eds., Seventh Annual Forest Inventory and Analysis Symposium, Portland, Maine, October 3-6, 2005, Proceedings: Washington, D.C., U.S. Department of Agriculture Forest Service, General Technical Report WO-77, p. 309-319.

*Toschik, P.C., Christman, M.C., Rattner, B.A., and Ottinger, M.A., 2006, Evaluation of osprey habitat suitability and interaction with contaminant exposure: Journal of Wildlife Management, v. 70, no. 4, p. 977-988.

*Trammell, E.J.; Berry, Kate; Bassett, Scott; and Sada, D.W., 2008, Distribution and recovery of vegetational assemblages in Ash Meadows National Wildlife Refuge, Nevada: Southwestern Naturalist, v. 53, no. 3, p. 326-334.

*Trapp, J.R., 2004, Wolf den site selection and characteristics in the northern rocky mountains-A multi-scale analysis: Prescott, Ariz., Prescott College, Master's thesis, 63 p.

*Triant, D.A., Pace, R.M., and Stine, Michael, 2004, Abundance, genetic diversity and conservation of Louisiana black bears (Ursus americanus luteolus) as detected through noninvasive sampling: Conservation Genetics, v. 5, no. 5, p. 647-659. 
Trochim, W.M., Marcus, S.E., Masse, L.C., Moser, R.P., and Weld, P.C., 2008, The evaluation of large research initiatives - A participatory integrative mixed-methods approach: American Journal of Evaluation, v. 29, no. 1, p. 8-28.

*Tumbusch, M.L., and Plume, R.W., 2006, Hydrogeologic framework and ground-water levels in basinfill deposits of the Diamond Valley flow system, central Nevada: U.S. Geological Survey Scientific Investigations Report 2006-5249, 1 pl., accessed January 30, 2011, at http://pubs.usgs.gov/sir/2006/5249/Plate01.pdf.

*Turner, Dale; Marshall, Rob; Enquist, Carolyn; Gondor, Anne; Gori, Dave; Lopez, Eduardo; Luna, Gonzalo; Aguilar, R.P.; Watts, Chris; and Schwartz, Sabra, 2005, Conservation priorities in the Apache Highlands ecoregion, in Gottfried, G.J., Gebow, B.S., Eskew, L.G., and Edminster, C.B., comps., Connecting mountain islands and desert seas-Biodiversity and management of the Madrean Archipelago II, Proceedings: Fort Collins, Colo., U.S. Department of Agriculture Forest Service, Rocky Mountain Research Station, RMRS-P-36, p. 375-379.

*Tuxen, K., and Kelly, M., 2008, The OakMapper WebGIS-Improved access to Sudden Oak Death spatial data, in Frankel, S.J., Kliejunas, J.T., and Palmieri, K.M., tech. coords., Sudden Oak Death Third Science Symposium, 2008, Proceedings: Albany, Calif., U.S. Department of Agriculture Forest Service, Pacific Southwest Research Station, General Technical Report PSW-GTR-214, p. 65-71.

*Twilley, R.R.; Couvillion, B.R.; Hossain, Imtiaz; Kaiser, Carola; Owens, A.B.; Steyer, G.D.; and Visser, J.M., 2008, Coastal Louisiana ecosystem assessment and restoration program-The role of ecosystem forecasting in evaluating restoration planning in the Mississippi River Deltaic plain: American Fisheries Society Symposium, v. 64, p. 29-46.

*U.S. Department of Energy, 2005, Environmental assessment for the proposed withdrawal of public lands within and surrounding the Caliente Rail Corridor, Nevada: Las Vegas, Nev., U.S. Department of Energy, Office of Civilian Radioactive Waste Management, 30 p., accessed September 16, 2008, at http://ocrwm.doe.gov/transport/pdf/final_ea.pdf.

**U.S. Environmental Protection Agency, 2002, Final report southeastern ecological framework: U.S. Environmental Protection Agency, Region 4, Planning and Analysis Branch, 295 p.

U.S. Environmental Protection Agency, 2006, Bibliometric analysis for the U.S. Environmental Protection Agency/Office of Research and Development's Human Health Research Program: U.S. Environmental Protection Agency, 27 p., accessed June 25, 2010, at http://www.epa.gov/hhrp/files/human_health_bibliometric_analysis.pdf.

*U.S. Forest Service, 2005, Forest stewardship spatial analysis project-Iowa methodology: Washington, D.C., U.S. Department of Agriculture Forest Service, 19 p., accessed March 2, 2011, at http://www.fs.fed.us/na/sap/products/IA/IA-Methodology.pdf.

*U.S. Forest Service, 2006, Forest stewardship spatial analysis project - Ohio methodology: Washington, D.C., U.S. Department of Agriculture Forest Service, 8 p., accessed January 17, 2011, at http://www.fs.fed.us/na/sap/products/OH/OH-Methodology.pdf.

*Underwood, E.C., Klaumeyer, K.R., Cox, R.L., Busby, S.M., Morrison, S.A., and Shaw, M.R., 2009, Expanding the global network of protected areas to save the imperiled mediterranean biome:

Conservation Biology, v. 23, no. 1, p. 43-52.

*Underwood, Jared, White, C.M., and Rodriguez, R.L., 2006, Winter movement and habitat use of northern goshawks breeding in Utah: Studies in Avian Biology, v. 31, p. 228-238.

*van Leeuwen, W.J.D., 2008, Monitoring the effects of forest restoration treatments on post-fire vegetation recovery with MODIS multitemporal data: Sensors, v. 8, p. 2017-2042.

van Raan, A.F.J., 1989, Evaluation of research groups, in Evered, David, and Harnett, Sara, eds., The evaluation of scientific research: Chichester, John Wiley \& Sons, p. 169-187. 
*Vander Lee, Bruce; Smith, Ruth; and Bate, Joanna, n.d., Ecological and biological diversity of the Carson National Forest, chap. 14 of Ecological and biological diversity of National Forests in Region 3: Nature Conservancy, accessed January 11, 2011, at $h t t p: / / w w w . f s . f e d . u s / o u t e r n e t / r 3 /$ plan-revision/assess/car/ebd-ch14-car.pdf.

*Vander Lee, Bruce; Smith, Ruth; and Bate, Joanna, n.d., Ecological and biological diversity of the Coconino National Forest, chap. 8 of Ecological and biological diversity of National Forests in Region 3: Nature Conservancy, accessed March 3, 2011, at http://74.125.155.132/ scholar? $q=$ cache:RlBzEmKvd8wJ:scholar.google.com/ $+\% 22$ in + region $+3 \% 22 \& h l=e n \& a s \_s d t=0,6$.

*Vander Lee, Bruce; Smith, Ruth; and Bate, Joanna, n.d., Ecological and biological diversity of the Prescott National Forest, chap. 9 of Ecological and biological diversity of National Forests in Region 3: Nature Conservancy, accessed March 4, 2011, at http://74.125.155.132/scholar?q=cache:fWKj_vcHeYcJ:scholar.google.com/\&hl=en\&as_sdt=0,6. *Vander Lee, Bruce; Smith, Ruth; and Bate, Joanna, n.d., Ecological and biological diversity of the Santa Fe National Forest, chap. 13 of Ecological and biological diversity of National Forests in Region 3: Nature Conservancy, accessed March 2, 2011, at http://www.fs.fed.us/outernet/r3/ plan-revision/assess/sfelebd-chl3-sfe.pdf.

*Vandergast, A.G., Bohonak, A.J., Weissman, D.B., and Fisher, R.N., 2007, Understanding the genetic effects of recent habitat fragmentation in the context of evolutionary history-Phylogeography and landscape genetics of a southern California endemic Jerusalem cricket (Orthoptera: Stenopelmatidae: Stenopelmatus): Molecular Ecology, v. 16, no. 5, p. 977-992.

Verbeek, Arnold; Debackere, Koenraad; Luwel, Marc; and Zimmermann, Edwin, 2002, Measuring progress and evolution in science and technology- - - The multiple uses of bibliometric indicators: International Journal of Management Reviews, v. 4, no. 2, p. 179-211.

*Viers, J.H., McCoy, M.C., Quinn, J.F., Willett, K.B., and Lehmer, Eric, 1998, California rivers assessment-Assembling environmental data to characterize California's watersheds: University of California, Davis, Information Center for the Environment Publications, Information Center for the Environment, John Muir Institute of the Environment, accessed February 26, 2011, at http://escholarship.org/uc/item/7hv149vz.

*Vogelmann, James; Zhu, Zhilang; Kost, Jay; Tolk, Brian; and Ohlen, Donald, 2006, Perspectives on LANDFIRE prototype project accuracy assessment, chap. 13 of Rollins, M.G., and Frame, C.K., eds., The LANDFIRE prototype project-Nationally consistent and locally relevant geospatial data for wildland fire management: Fort Collins, Colo., U.S. Department of Agriculture Forest Service, Rocky Mountain Research Station, General Technical Report RMRS-GTR-175, p. 397-411.

*Vogelmann, J.E., Sohl, T.L., Campbell, P.V., and Shaw, D.M., 1998, Regional land cover characterization using Landsat thematic mapper data and ancillary data: Environmental Monitoring and Assessment, v. 51, p. 415-428.

*Volin, J.C.; Liu, Zhongwei; Higer, Aaron; Mazzotti, Frank; Owen, Dianne, Allen, Jenny, and Pearlstine, Leonard, 2008, Validation of a spatially continuous EDEN water-surface model for the Everglades, Florida: Department of Natural Resources and the Environment Articles, paper 8, accessed March 5, 2011, at http://digitalcommons.uconn.edu/nrme_articles/8.

*Wade, A.A., and Theobald, D.M., 2010, Residential development encroachment on U.S. protected areas: Conservation Biology, v. 24, no. 1, p. 151-161.

*Walker, Richard, and Craighead, Lance, 1997, Analyzing wildlife movement corridors in Montana using GIS, in 1997 ESRI User Conference, San Diego, Calif., Proceedings: Redlands, Calif., Environmental Systems Research Institute (ESRI), paper 116, accessed August 17, 2010, at http://proceedings.esri.com/library/userconf/proc97/proc97/to150/pap116/p116.htm. 
*Walker, Richard, and Craighead, Lance, 1998, Corridors-Key to wildlife from Yellowstone to Yukon, in Harvey, Ann, ed., A sense of place-Issues, attitudes and resources in the Yellowstone to Yukon ecoregion: Canmore, Alberta, Yellowstone to Yukon Conservation Initiative, accessed February 18, 2011, at http://www.y2y.net/data/1/rec_docs/661_A_Sense_of_Place,_the_Y2Y_Atlas.pdf\#page $=123$.

*Walker, S.C., Mann, D.K., and McArthur, E.D., 1996, Plant community changes over 54 years within the Great Basin experimental range, Manti-La Sal National Forest, in Barrow, J.R., McArthur, E.D., Sosebee, R.E., and Tausch, R.J., comps., Shrubland ecosystem dynamics in a changing environment, May 23-25, 1995, Las Cruces, N. Mex., Proceedings: Ogden, Utah, U.S. Department of Agriculture Forest Service, Intermountain Research Station, General Technical Report INT-GTR-338, p. 66-68.

*Wall, S.S., and Berry, C.R., Jr., 2006, The importance of multiscale habitat relations and biotic associations to the conservation of an endangered fish species, the Topeka shiner: American Fisheries Society Symposium, v. 48, p. 305-322.

Wallin, J.A., 2005, Bibliometric methods-Pitfalls and possibilities: Basic and Clinical Pharmacology \& Toxicology, v. 97, no. 5, p. 261-275.

*Walter, W.D., Leslie, D.M., Hellgren, E.C., and Engle, D.M., 2010, Identification of subpopulations of North American elk (Cervus elaphus L.) using multiple lines of evidence-Habitat use, dietary choice, and fecal stable isotopes: Ecological Research, v. 25, no. 4, p. 789-800.

*Wamsley, T.V., Cialone, M.A., Smith, J.M., Atkinson, J.H., and Rosati, J.D., 2010, The potential of wetlands in reducing storm surge: Ocean Engineering, v. 37, no. 1, p. 59-68.

*Wamsley, T.V., Cialone, M.A., Westerink, Joannes, and Smith, J.M., 2009, Influence of marsh restoration and degradation on storm surge and waves: Vicksburg, Miss., U.S. Army Corps of Engineers, Engineer Research and Development Center, ERDC/CHL CHETN-1-77, 11 p., accessed January 11, 2011, at http://www.ocpr.louisiana.gov/crm/D\%20R\%20S\%20Reports\%5CGeneral3\%5CInfluence\%20of\%20 Marsh\%20Restoration\%20and\%20Degradation\%20on\%20Storm\%20Surge\%20and\%20Waves.pdf.

*Wang, Dali, Berry, M.W., Carr, E.A., Comiskey, E.J., and Gross, L.J., 2005, A parallel simulation framework for integrated regional ecosystem modeling: Knoxville, University of Tennessee, unpublished manuscript, accessed March 4, 2011, at http://www.tiem.utk.edu/gem/paper2/IEEEPDS.pdf.

*Wang, Dali; Buchanan, Nick; Berry, M.W.; Carr, Eric; Comiskey, J.E.; Gross, L.J.; and Shaw, S.L., 2006, A GIS-enabled distributed simulation framework for high performance ecosystem modeling, in 2006 ESRI International User Conference, San Diego, Calif., Proceedings: Redlands, Calif., Environmental Systems Research Institute (ESRI), paper 1272, accessed February 18, 2011, at http://proceedings.esri.com/library/userconf/proc06/papers/papers/pap_1272.pdf.

*Wang, Dali, Carr, Eric, Gross, L.J., and Berry, M.W., 2005, Toward ecosystem modeling on computing grids: Computing in Science and Engineering, v. 9, no.1, p. 44-52.

*Wang, Fei, 2002, Design and implementation of Web-based GIS for forest fragmentation analysis: Morgantown, West Virginia University, Master's thesis, 107 p.

*Wang, Steven; Stiles, Thomas; Flynn, Trevor; Stahl, A.J.; Gutierrez, J.L.; Angelo, R.T.; and Frees, Lyle, 2009, A modeling approach to water quality management of an agriculturally dominated watershed, Kansas, USA: Water, Air, and Soil Pollution, v. 203, nos. 1-4, p. 193-206.

*Ward, Kathleen, and Juzwik, Jennifer, 2005, Change in the Minneapolis/St. Paul Metropolitan area oak forests from 1991 to 1998: St. Paul, Minn., U.S. Department of Agriculture Forest Service, North Central Research Station, Research Note NC-389, 8 p., accessed March 24, 2011, at http://nrs.fs.fed.us/pubs/rn/rn_nc389.pdf. 
*Ward, Kathleen; Ostry, Michael; Venette, Robert; Palik, Brian; Hansen, Mark; Hatfield, Mark, 2009, Assessment of black ash (Fraxinus nigra) decline in Minnesota, in McRoberts, R.E., Reams, G.A., Van Deusen, P.C., McWilliams, W.H., eds., Eighth Annual Forest Inventory and Analysis Symposium, Monterey, Calif., October 16-19, 2006, Proceedings: Washington, D.C., U.S. Department of Agriculture Forest Service, General Technical Report WO-79, p. 115-120. *Wardlow, B.D., and Egbert, S.L., 2003, A state-level comparative analysis of the GAP and NLCD land-cover data sets: Photogrammetric Engineering \& Remote Sensing, v. 69, no. 12, p. 1387-1397. *Wardlow, B.D., and Egbert, S.L., 2008, Large-area crop mapping using time-series MODIS $250 \mathrm{~m}$ NDVI data-An assessment for the U.S. central Great Plains: Remote Sensing of Environment, v. 112, p. 1096-1116.

*Warren, D.L., and Seifert, S.N., 2011, Environmental niche modeling in Maxent—The importance of model complexity and the performance of model selection criteria: Ecological Applications, v. 21, no. 2, p. 335-342.

*Watt, C.L., Tappe, P.A., and Roth, M.F., 2002, Concentrations of American alligator populations in Arkansas: Journal of the Arkansas Academy of Science, v. 56, p. 243-249.

*Weathers, H.D., Hayes, M.O., and Michel, Jacqueline, 2009, Reach sensitivity index mapping of the Amite River Watershed in the Lake Ponchartrain Basin-A tool for watershed restoration: Journal of Coastal Research, v. SI, no. 54, p. 141-151.

*Webb, E.B., Smith, L.M., Vrtiska, M.P., and Lagrange, T.G., 2010, Effects of local and landscape variables on wetland bird habitat use during migration through the Rainwater Basin: Journal of Wildlife Management, v. 74, no. 1, p. 109-119.

*Webb, W.C., Boarman, W.I., and Rotenberry, J.T., 2009, Movements of juvenile common ravens in an arid landscape: Journal of Wildlife Management, v. 73, no. 1, p. 72-81.

*Weber, T.C., 2007, Development and application of a statewide conservation network in Delaware, U.S.A.: Journal of Conservation Planning, v. 3, p. 17-46.

*Weber, Ted, 2007, An assessment of Cecil County's green IInfrastructure-Technical report for the Cecil County green infrastructure plan: Annapolis, Md., The Conservation Fund, unpublished manuscript, 14 p., accessed April 6, 2011, at http://www.ccgov.org/uploads/PlanningAndZoning/General/CecilCoMD_TechReport\%20-\%20 Green\%20Infrastructure.pdf.

*Weisz, Reuben; Triepke, Jack; and Truman, Russ, 2009, Evaluating the ecological sustainability of a ponderosa pine ecosystem on the Kaibab Plateau in northern Arizona: Fire Ecology, v. 5, no. 1, p. $100-114$.

*Wells, M.L.; O'Leary, J.F.; Franklin, Janet; Michaelsen, Joel; and McKinsey, D.E., 2004, Variations in a regional fire regime related to vegetation type in San Diego County, California (USA): Landscape Ecology, v. 19, p. 139-152.

*Wells, W.K., 2010, Object-based segmentation and classification of one meter imagery for use in forest management plans: Logan, Utah State University, Master's thesis, 49 pp., accessed March 4, 2011, at http://digitalcommons.usu.edu/cgi/viewcontent.cgi? article $=1649 \&$ context $=$ etd .

*Westerink, J.J., Luettich, R.A., Feyen, J.C., Atkinson, J.H., Dawson, Clint, Roberts, H.J., Powell, M.D., Dunion, J.P., Kubatko, E.J., and Pourtaheri, Hasan, 2008, A basin- to channel-scale unstructured grid hurricane storm surge model applied to southern Louisiana: Monthly Weather Review, v. 136, p. 833-864.

*Westfall, R.D., and Millar, C.I., 2004, Reconstructing a past climate using current multi-species' climate spaces [abs.]: AGU Fall Meeting abstracts, accessed March 3, 2011, at http://www.fs.fed.us/ psw/cirmount/meetings/agu/pdf2004/westfall_millar_climate_modeling_poster.pdf. 
*Westrick, K.J., Storck, Pascal, and Mass, C.F., 2002, Description and evaluation of a hydrometeorological forecast system for mountainous watersheds: Weather and Forecasting, v. 17, p. 250-262.

*White, C.G., Zager, Peter, and Gratson, M.W., 2010, Influence of predator harvest, biological factors, and landscape on elk calf survival in Idaho: Journal of Wildlife Management, v. 74, no. 3, p. 355-369.

*White, Denis, Preston, E.M., Freemark, K.E., and Kiester, A.R., 1999, A hierarchical framework for conserving biodiversity, chap. 8 of Klopatek, J.M., and Gardner, R.H., eds., Landscape ecological analysis - Issues and applications: New York, Springer-Verlag, p. 127-153.

*White, M.A., and Host, G.E., 2000, Mapping range of natural variation ecosystem classes for the northern Superior uplands - Draft map and analytical methods: Duluth, University of Minnesota, Duluth, Natural Resources Research Institute, NRRI/TR-2000/39, 13 p., accessed March 16, 2011, at http://www.frc.state.mn.us/documents/council/landscape/NE\%20Landscape/Mapping_RNV_ EcosystemClasses_for_NorthernSuperiorUplands_NE_MN_2000-08-09_DraftReport.pdf.

*Williams, J.W., Seabloom, E.W., Slayback, Daniel, Stoms, D.M., and Viers, J.H., 2005, Anthropogenic impacts upon plant species richness and net primary productivity in California: Ecology Letters, v. 8, p. 127-137.

*Winer, A.M., and Karlik, J.F., 2001, Development and validation of databases for modeling biogenic hydrocarbon emissions in California's airsheds: Los Angeles, California Air Resources Board, 179 p. accessed February 11, 2011, at http://arb.ca.gov/research/seminars/winer/winer1.PDF.

*Witty, J.H., Graham, R.C., Hubbert, K.R., Doolittle, J.A., and Wald, J.A., 2003, Contributions of water supply from the weathered bedrock zone to forest soil quality: Geoderma, v. 114, nos. 3-4, p. 389-400.

*Wolter, P.T., Johnston, C.A., and Niemi, G.J., 2006, Land use land cover change in the U.S. Great Lakes Basin 1992 to 2001: Journal of Great Lakes Research, v. 32, p. 607-628.

*Woolmer, Gillian, Trombulak, S.C., Ray, J.C., Doran, P.J., Anderson, M.G., Baldwin, R.F., Morgan, Alexis, and Sanderson, E.W., 2008, Rescaling the human footprint-A tool for conservation planning at an ecoregional scale: Landscape and Urban Planning, v. 87, p. 42-53.

*Wooten, George, 2002, Shrub-steppe conservation prioritization in Washington state: Republic, Wash., Kettle Range Conservation Group, unpublished manuscript, 22 p., accessed April 6, 2011, at http://www.kettlerange.org/steppeweb/Shrub-steppe-report-KRCG-7.pdf.

*Wright, R.G., MacCracken, J.G., and Hall, Joel, 1994, An ecological evaluation of proposed new conservation areas in Idaho-Evaluating proposed Idaho national parks: Conservation Biology, v. 8, no. 1, p. 207-216.

*Wright, R.G., Murray, M.P., and Merrill, Troy, 1998, Ecoregions as a level of ecological analysis: Biological Conservation, v. 86, p. 207-213.

*Wright, R.G., and Scott, J.M., 1996, Evaluating the ecological suitability of lands for parks and protected areas using gap analysis databases, chap. 7 of Wright, R.G., and Lemons, J., eds., National parks and protected areas-Their role in environmental protection: Cambridge, Mass., Blackwell Science, p. 121-131.

*Wright, R.G., Scott, J.M., Mann, Shannon, and Murray, Michael, 2001, Identifying unprotected and potentially at risk plant communities in the Western USA: Biological Conservation, v. 98, p. 97-106.

*Yanoff, Steven, and Muldavin, Esteban, 2008, Grassland-shrubland transformation and grazing-A century-scale view of a northern Chihuahuan Desert grassland: Journal of Arid Environments, v. 72, no. 9, p. 1594-1605.

*Yuan, Fei, and Roy, S.S., 2007, Analysis of the relationship between NDVI and climate variables in Minnesota using geographically weighted regression and spatial interpolation, in ASPRS 2007 
Annual Conference, Tampa, Fla., 2007, Proceedings: Bethesda, Md., American Society for Photogrammetry and Remote Sensing (ASPRS), 6 p., accessed March 24, 2011, at http://www.asprs.org/publications/proceedings/tampa2007/0083.pdf.

*Zack, Steve; Chase, M.K.; Geupel, G.R.; and Stralberg, Diana, 2005, The oak woodland bird conservation plan - A strategy for protecting and managing oak woodland habitats and associated birds in California, in Ralph, C.J., and Rich, T.D., eds., Bird conservation implementation and integration in the Americas, Third International Partners in Flight Conference, Asilomar, Calif., March 20-24, 2002, Proceedings, v. 1: Albany, Calif., U.S. Department of Agriculture Forest Service, Pacific Southwest Research Station, General Technical Report PSW-GTR-191, p. 174-178.

*Zasada, Michal, Cieszewski, C.J., and Lowe, R.C., 2003, Impact of stream management zones and road beautifying buffers on long-term fiber supply in Georgia, in McRoberts, R.E., Reams, G.A., Van Deusen, P.C., and McWilliams, W.H., eds., Fifth Annual Forest Inventory and Analysis Symposium, New Orleans, La., November 18-20, 2003, Proceedings: U.S. Department of Agriculture, Forest Service, General Technical Report WO-69, p. 41-47.

*Zasada, Michal, Cieszewski, C.J., Lowe, R.C., Zawadzki, Jarek, Clutter, Mike, and Siry, J.P., 2005, Using FIA and GIS data to estimate areas and volumes of potential stream management zones and road beautifying buffers, in McRoberts, R.E., Reams, G.A., Van Deusen, P.C., McWilliams, W.H., and Cieszewski, C.J., eds., Fourth Annual Forest Inventory and Analysis Symposium, New Orleans, La., November 19-21, 2002, Proceedings: St. Paul, Minn., U.S. Department of Agriculture, Forest Service, North Central Research Station, General Technical Report NC-252, p. 253-257.

*Zhan, Xiaoyong, and Huang, M.L., 2004, ArcCN-Runoff-An ArcGIS tool for generating curve number and runoff maps: Environmental Modelling \& Software, v. 19, no. 10, p. 875-879.

*Zicus, M.C.; Rave, D.P.; Fieberg, John; Giudice, John; and Wright, Robert, 2005, Minnesota's ringnecked ducks-A pilot breeding pair survey in Wingate, P.J., Kimmel, R.O., Lawrence, J.S.and Lenarz, M.S., eds., Summaries of Wildlife Research Findings 2004: St. Paul, Minnesota Department of Natural Resources, p. 137-158, accessed March 12, 2011, at http://www.leg.state.mn.us/docs/2006/Other/060492.pdf\#page=137.

*Zicus, M.C., Rave, D.P., Fieberg, J.R., Guidice, J.H., and Wright, R.G., 2008, Distribution and abundance of Minnesota breeding ring-necked ducks Aythya collaris: Wildfowl, v. 58, p. 31-45. 